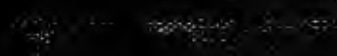



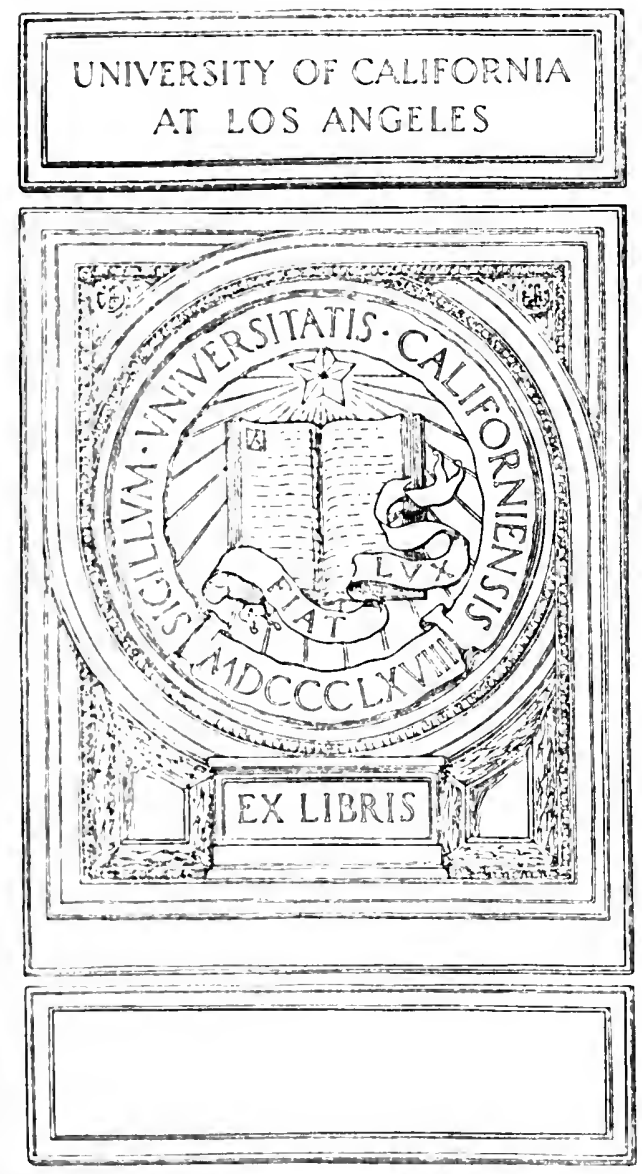
Digitized by the Internet Archive in 2007 with funding from Microsoft Corporation 





\title{
MISCELLANEOUS ADDRESSES
}

\author{
BY \\ ELIHU ROOT
}

COLLECTED AND EDITED BY

ROBERT BACON

AND

JAMES BROWN SCOTT

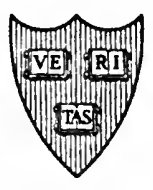

\section{CAMBRIDGE}

HARVARD UNIVERSITY PRESS

LONDON: HUMPIREY MILFORD

Oxford Univensity Press

1917 
COPYRIGHT, 1917

HARVARD UNIVERSITY PRESB 


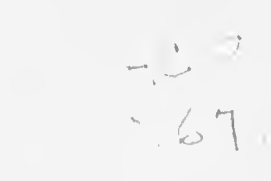

\section{CONTENTS}

IntroductoRx Note . . . . . . . . . . . . . vii

The Iroquois and the Struggle for America . . . . 3

Address at the tercentennial celebration of the discovery of

Lake Champlain, Plattsburg, July 7, 1909.

Samuel Kirkland: Founder of Hamilton College . .

Address at the exercises attending the laying of the corner stone of the new Dartmouth Hall and the visit of the Earl of Dartmouth to Dartmouth College, October 26, 1904.

The Centenary of Hamilton College . . . . . . . .

Historical Address at the centennial celebration, at Clinton, New York, June 17, 1912.

Address as Honorary Chancellor of Union University, Schnectady, New York, June 10, 1914 . .

The Home of the Oneidas ............

Address before the Society of the Sons of Oneida, New York

City, March 14, 1903.

James Schoolcraft Sherman . . . . . . . .

Address at the memorial exercises, United States Senate, February 15, 1913.

Inauguration of President Brown . . . . . . . .

Response for the Educational Foundations at the inauguration of Dr. Elmer Ellsworth Brown as Chancellor of New York University, November 9, 1911.

The Object and the Opportunity of Colombia Uni-

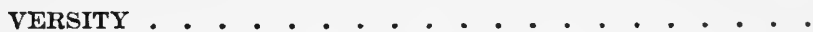

Remarks upon the conferring of the doctorate of law, June 8, 1904.

The Supreme Treasure of Our Country . . . . .

Remarks upon receiving the degree of doctor of laws from the University of the State of New York, October 22, 1915.

The Dutch Founders of New York. . . . . . .

Remarks at the sixty-first anniversary dinner of the Saint

Nicholas Society of the City of New York, December 7, 1896. 
JoHN HAY . . . . . . . . . . . . . . . . . . . . . .

Address at the dedication of the John Hay Library, Brown University, November 11, 1910.

Grover Cleveland . . . . . . . . . . . .

Memorial Address at the College of the City of New York, March 18, 1909.

Chester Alan Arthur

Address at the unveiling of a statue of President Arthur in Madison Square, New York, June 13, 1899.

William Tecumsen Sherman . . . . . . . . . Address at the unveiling of St. Gaudens' statue of General Sherman, in New York, May 30, 1903.

The Great Reconciliation . . . . . . . . . . Address at a reunion of the Union and Confederate veterans who fought at Fort Fisher. Utica, New York, September 9, 1909.

The Union League Club .............. 123

Address at a meeting of the club to celebrate its fortieth anniversary, February 6, 1903.

The City of New York. . . . . . . . . .

Remarks at the celebration of the two hundred and fiftieth anniversary of the founding of its municipal government, May 26, 1903.

Tile Old and the New New York

Address at a dinner of the Lotos Club in honor of the Secretary of War, New York, May 9, 1903.

Benjamin Frankun

Address on presenting to France the gold medal authorized by Congress. The Franklin Bicentennial, Philadelphia, April 20, 1906.

Reply of M. Jusserand, the French Ambassador . . 143

Jules Martin Cambon ............. 145

Address at a farewell dinner to the French Ambassador, November 15, 1902.

The Assassination of President Carnot

Remarks in the New York constitutional convention on a resolution tendering to the Government of France the sympathy of the convention in the death of President Carnot by assassination, June 26, 1894. 
Canada and the United States ...........

Address at a dinner given by the Pilgrims of the United States in honor of the Right Honorable Earl Grey, GovernorGeneral of Canada, New York, March 31, 1906.

The Builders of Canada .............

Address at a banquet of the Canadian Club of Ottawa, Canada, January 22, 1907.

The Canadian Reciprocity Agreement .......

Address in the United States Senate upon the bill to promote reciprocal trade relations with the Dominion of Canada, June 21, 1911.

Art and Architecture in America .........

Remarks at the annual dinner of the American Institute of Architects, Washington, D. C., January 11, 1905.

Charles Follen MCKim . . . . . . . . . .

Address at a memorial meeting, New Theater, New York, November 23, 1909.

Charles Follen McKim.

Address at a memorial meeting of the American Institute of Architects, Washington, D. C., December 15, 1909.

Francis Davis Millet

Address at a memorial meeting of the American Federation of Arts, Washington, D. C., May 10, 1912.

The Place of Cardinal Gibbons . . . . . . . . .

Address at the Cardinal Gibbons Civic Demonstration, Baltimore, June 6, 1911.

Joseph G. CANNON. . . . . . . . . . . . .

Remarks at a dinner in his honor at Waskington, D. C., February $15,1913$.

A Tribute to Theodore Roosevelt ........

Address at a banquet in honor of the Secretary of War. The Union League Club, New York, February 3, 1904.

Jorin Pierpont Morgan ..............

Address at the memorial meeting of the Chamber of Commerce of the State of New York, April 3, 1913.

Jomn Marshall Harlan ..............

Address at the memorial exercises in the United States Supreme Court, December 16, 1911. 
Melville Weston Fuller . . . . . . . . . . . .

Address at the proceedings of the bar and officers of the Supreme Court of the United States, December 10, 1910.

Judge John Davis . . . . . . . . . . . . .

Address at a memorial meeting of the bar of the Court of Claims, May 16, 1902.

Justice George Carter-Barrett . . . . . . . . .

Address at the meeting of the bench and bar in memory of the Honorable George Carter-Barrett, New York City, November $10,1906$.

Justice Charles H. Van Brunt ..... . . . . . .

Address in presenting to the Appellate Division of the Supreme Court of the State of New York in the First Department, a portrait of the Honorable Charles H. Van Brunt, first presiding justice of the court, June 8, 1897.

Business and Politics

Address at a reception of the Union League Club of Philadelphia, in his honor, Mareh 23, 1915.

The Preservation of American Ideals . . . . . . .

Address at a dinner of the Union League Club, Chicago, Illinois, in commemoration of the birthday of Washington, February 22, 1904.

The Monroe Doctrine

Address at the ninety-ninth annual banquet of the New England Society of New York, December 22, 1904.

Tue Causes of War . . . . . . . . . . . . . .

Address at a dinner of the New York Peace Society, in recognition of the services of the Secretary of State to international peace, February 26, 1909.

The Effect of Democracy on International Law .

Presidential address at the eleventh annual meeting of the American Society of International Law, Washington, D. C., April 26, 1917.

The Spread of International Law in the Americas .

Remarks at a dinner of the Division of International Law of the Carnegie Endowment for International Peace and the Pan-American Scientific Congress, Washington, D.C., December 30,1915 . 


\section{INTRODUCTORY NOTE}

Tre collected addresses and state papers of Elihu Root, of which this is one of several volumes, cover the period of his service as Secretary of War, as Secretary of State, and as Senator of the United States, during which time, to use his own expression, his only client was his country.

The many formal and occasional addresses and speeches, which will be found to be of a remarkably wide range, are followed by his state papers, such as the instructions to the American delegates to the Second Hague Peace Conference and other diplomatic notes and documents, prepared by him as Secretary of State in the performance of his duties as an executive officer of the United States. Although the official documents have been kept separate from the other papers, this plan has been slightly modified in the volume devoted to the military and colonial policy of the United States, which includes those portions of his official reports as Secretary of War throwing light upon his public addresses and his general military policy.

The addresses and speeches selected for publication are not arranged chronologically, but are classified in such a way that each volume contains addresses and speeches relating to a general subject and a common purpose. The addresses as president of the American Society of International Law show his treatment of international questions from the theoretical standpoint, and in the light of his experience as Secretary of War and as Secretary of State, unrestrained and uncontrolled by the limitations of official position, whereas his addresses on foreign affairs, delivered while Secretary of State or as United States Senator, discuss these questions under the reserve of official responsibility. 
Mr. Root's addresses on government, citizenship, and legal procedure are a masterly exposition of the principles of the Constitution and of the government established by it; of the duty of the citizen to understand the Constitution and to conform his conduct to its requirements; and of the right of the people to reform or to amend the Constitution in order to make representative government more effective and responsive to their present and future needs. The addresses on law and its administration state how legal procedure should be modified and simplified in the interest of justice rather than in the supposed interest of the legal profession.

The addresses delivered during the trip to South America and Mexico in 1906, and in the United States after his return, with their message of good will, proclaim a new doctrine the Root doctrine - of kindly consideration and of honorable obligation, and make clear the destiny common to the peoples of the Western World.

The addresses and the reports on military and colonial policy made by Mr. Root as Secretary of War explain the reorganization of the army after the Spanish-American War, the creation of the General Staff, and the establishment of the Army War College. They trace the origin of and give the reason for the policy of this country in Cuba, the Philippines, and Porto Rico, devised and inaugurated by him. It is not generally known that the so-called Platt Amendment, defining our relations to Cuba, was drafted by Mr. Root, and that the Organic Act of the Philippines was likewise the work of Mr. Root as Secretary of War.

The argument before The Hague Tribunal in the North Atlantic Fisheries Case is a rare if not the only instance of a statesman appearing as chief counsel in an international arbitration, which, as Secretary of State, he had prepared and submitted. 
The miscellaneous addresses, including educational, historical, and commemorative addresses, the political speeches in days of peace, and the stirring and prophetic utterances in anticipation of and during our war with Germany, delivered at home and on special mission in Russia, should make known to future generations the literary, artistic, and emotional side of this broad-minded and far-seeing statesman of our time.

The publication of these collected addresses and state papers will, it is believed, enable the American people better to understand the generation in which Mr. Root has been a commanding figure, and better to appreciate during his lifetime the services which he has rendered to his country.

Robert Bacon.

JAMEs Brown Scott.

SePtember 16, 1917. 

MISCELLANEOUS ADDRESSES 



\title{
THE IROQUOIS AND THE STRUGGLE FOR AMERICA
}

\author{
ADDRESS AT THE TERCENTENNIAL CELEBRATION OF THE \\ DISCOVERY OF LAKE CHAMPLAIN, PLATTSBURG, \\ JULY 7, 1909
}

The four addresses with which this volume opens, are intimately associated in that they have to do with the early history of New York State, the relations between the white settlers and the aborigines, and the efforts to educate the Indians under the devoted guidance of Eleazar Wheelock and particularly of Samuel Kirkland, the founder of the Hamilton Oneida Academy, out of which grew Hamilton College, at whose centennial celebration in $1912 \mathrm{Mr}$. Root made the historical address.

$\mathrm{T}^{\mathrm{T}} \mathrm{T}$ is no ordinary event that we celebrate. The beauty of 1 this wonderful lake, first revealed to the eye of civilized man by the visit of Samuel de Champlain three hundred years ago; the powerful personality, noble character, and romantic career of the discoverer; the historic importance of this controlling line of strategic military communication, along which have passed in successive generations the armies whose conflicts were to determine the control and destinies of great empires; the value to Canada and to the United States of this natural pathway of commerce; the growth and prosperity of the noble states that have arisen on the opposing shores; their contributions to the wealth of mankind, to civil and religious liberty, to the world's progress in civilization - all these withdraw the first coming of the white man to Lake Champlain from the dull and uninteresting level of the commonplace: while comparative antiquity, so attractive and inspiring to the people of the New World, lends dignity and romance to the figures and the acts that have escaped oblivion through centuries. 
Even a dull imagination must be stirred, as it dwells upon the influence which the events attending the discovery were to have upon the issue of the great struggle between France and Great Britain for the control of the continent; the struggle between the two white races for the opportunity to colonize and expand, and between the two systems of law and civil polity, for the direction and development of civilization among the millions who were to people the vast region extending from the Atlantic to the Pacific and from the Rio Grande to the frozen limits of the North.

Authentic history records that late in June, 1609, Champlain, accompanied by several white companions and by a great array of Algonquin Indians of the Saint Lawrence Valley, left the French station on the site of the old Indian village of Stadacona, where now stands the city of Quebec, upon an expedition intended by the Indians for war and by the whites for exploration. They proceeded in canoes up the Saint Lawrence and turned south into the Richelieu, and, in the early days of July, after many vicissitudes and the desertion of the greater part of the Indians, they dragged their canoes around the rapids of the river and came to the foot of the lake on whose shores we stand. They proceeded up the lake with all the precautions of Indian warfare in an enemy's country. As they approached the head of the lake, they rested concealed by day, and urged forward their canoes by night. At last, in this month of July, three hundred years ago, they came upon a war party of the Iroquois. Both parties landed, in the neighborhood of the present Ticonderoga, and, with the coming of the dawn, joined battle. Protected by the light armor of the period, Champlain advanced to the front in full view of the contending parties, and, as the Iroquois drew their bows upon him, he fired his arquebus. One of his white companions also fired. The Iroquois chief and several of his warriors fell, killed or 
wounded; and the entire band, amazed and terror-stricken by their first experience with the inexplicable, miraculous, and death-dealing power of fire-arms, fled in dismay. 'They were pursued by the Algonquins, some were killed, some were taken prisoners, and the remainder returned to their homes to spread through all the tribes of the Iroquois the story that a new enemy had arisen bringing unheard of and supernatural powers to the aid of their traditional Algonquin foes. The shot from Champlain's arquebus had determined the part that was to be played in the approaching conflict by the most powerful military force among the Indians of North America. It had made the confederacy of the Iroquois and all its nations and dependencies the implacable enemies of the French and the fast friends of the English for all the long struggle that was to come.

A century or more before the white settlement, five Indian nations of the same stock and language, under the leadership of extraordinary political genius, had formed a confederacy for the preservation of internal peace and for common defense against external attack. Their territories extended in 1609 from the Saint Lawrence to the Susquehanna; from Lake Champlain and the Hudson to the Genesee, and, a few years later, to the Niagara. There dwelt side by side the Mohawks, the Oneidas, the Onondagas, the Cayugas, and the Senecas, in the firm union of Ho-de-no-saunee - the Long House of the Iroquois.

The Algonquin tribes that surrounded them were still in the lowest stage of industrial life, and for their food added to the spoils of the chase only wild fruits and roots. The Iroquois had passed into the agricultural stage. They had settled habitations and cultivated fields. They had extensive orchards of the apple, made sugar from the maple, and raised corn and beans and squash and pumpkins. The surrounding tribes had only the rudinentary political institution 
of chief and followers. The Iroquois had a carefully devised constitution, well adapted to secure confederate authority in matters of common interest, and local authority in matters of local interest.

Each nation was divided into tribes, the Wolf tribe, the Bear tribe, the Turtle tribe, etc. The same tribes ran through all the nations, the section in each nation being bound by ties of consanguinity to the sections of the same tribe in the other nations. Thus a Seneca Wolf was brother to every Mohawk Wolf, a Seneca Bear to every Mohawk Bear. The arrangement was like that of our college societies with chapters in different colleges. So there were bonds of tribal union running across the lines of national union; and the whole structure was firmly knit together as by the warp and woof of a textile fabric.

The government was vested in a council of fifty sachems, a fixed number coming from each nation. The sachems from each nation came in fixed proportions from specific tribes in that nation; the office was hereditary in the tribe; and the member of the tribe to fill it was elected by the tribe.

The sachems of each nation governed their own nation in all local affairs. Below the sachems were elected chiefs on the military side and keepers-of-the-faith on the religious side. Crime was exceedingly rare; insubordination was unknown; courage, fortitude, and devotion to the common good were universal.

The territory of the Long House covered the watershed between the Saint Lawrence basin and the Atlantic. From it the waters ran into the Saint Lawrence, the Hudson, the Delaware, the Susquehanna, and the Ohio. Down these lines of communication the war parties of the confederacy passed, beating back or overwhelming their enemies until they had become overlords of a vast region, extending far into 
New England, the Carolinas, the valley of the Mississippi, and to the coast of Lake Huron.

They held in subjection an area including the present states of New York, New Jersey, Pennsylvania, Delaware, Maryland, Ohio, Kentucky, West Virginia, northern Virginia and Tennessee, and parts of New England, Illinois, Indiana, Michigan and Ontario.

Of all the inhabitants of the New World, they were the most terrible foes and the most capable of organized and sustained warfare; and of all the inhabitants north of Mexico they were the most civilized and intelligent.

The century which followed the voyages of Columbus had been for the northern continent a period of exploration and discovery, of search for gold and for fabulous cities and for a passage to the Indies, of fugitive fur trade with the natives, of fisheries on the Banks, and of feeble, disastrous attempts at occupation, but not of permanent settlement. Ponce de León and De Soto and Verrazano, Cartier and the Cabots and Drake and Frobisher and Gilbert and Gosnold, had brought the western coast of the Atlantic out from the mists of fable; but they had left no trace upon its shores. Jean Ribaut and his French Huguenots had attempted to do for their religion in Florida what the Pilgrims did in the following century on the coast of Massachusetts; but their colony was destroyed with incredible cruelty, in the name of religion, by the ferocious Spaniard, Menéndez; and the colony of Menéndez was in turn destroyed by the Gascon, De Gourgues, save a feeble remnant on the site of Saint Augustine. Raleigh, with noble constancy and persistency, had wasted his fortune in repeated and vain attempts to establish a colony in Virginia. On the sites of the modern Quebec and Montreal, at Tadousac, at the mouth of the Saint Croix, and at Port Royal, Jacques Cartier and Roberval, Pontgrave and De Monts, Poutrincourt and Lescarbot, had seen their heroic 
and devoted efforts to establish a new France brought to naught by cold and starvation and disease. In that month of July, 1609, in all the vast expanse between Florida and Labrador, no settlement of white men held its place or presaged the coming of the future multitude, save at Jamestown, behind the Capes of Virginia, where Christopher Newport's handful of colonists had barely survived two years of privation, and at Quebec, where the undaunted Pontgrave and Champlain only one year before had again gained a foothold. At Jamestown, the mournful record of the winter of 1609 to 1610 shows us that in the spring but sixty of the colonists were living. At Quebec, twenty-eight Frenchmen with Champlain had braved the rigors of a Canadian winter, and in the spring of 1609 but eight remained alive.

In this same month of July, 1609, the Half Moon of Henry Hudson was repairing damages in Penobscot Bay after her voyage across the Atlantic, and preparing to sail on to the noble river that still bears her commander's name.

The field was open; the hands upon the margin that reached out to grasp control seemed few and feeble; but the period of preparation was past. The mighty forces that were to urge on the most stupendous movement of mankind in human history had already received their direction. The time was ripe for the real conflict to begin, and it had its momentous beginning when the Chief of the Mohawks fell before the arquebus of Champlain at Ticonderoga.

The conditions which limited the powers and directed the purposes of the various countries of Europe in the early years of the seventeenth century, made it inevitable that the struggle for American control should ultimately become a single combat between France and Great Britain.

It is true that Spain had overturned the tribal government of the Aztecs and held possession along the northern shores of the Gulf of Mexico, a vantage ground from which 
she might well have pressed to the northward successful plans of occupation. But Spain had no such plans. When the search for treasure had failed, and it was plain that no more Perus and Mexicos were to be found, the dark forests of the North Atlantic offered no attractions to the Spanish conquistadores, who sought the spoils of conquest rather than the rewards of labor.

With the death of Philip the Second, the decline of Spanish power had already begun. His successors were feeble and incapable. The stern, repressive, and despotic control over body and soul effected by the union of military and religious organization during the first century of united Spain was accompanied by a marvelous efficiency and energy that made Spain for a time the foremost maritime and colonizing power of the world. The price of that efficiency, however, was the loss of the only permanent source of national energy, the independence and free initiative of individual character among her citizens. Thenceforth Spain was no longer to sway the rod of empire, but, holding it weakly in feeble hands, was to lose one by one the world-wide possessions of Charles the Fifth and Philip the Second, until the time when the penalty of her national sin against civil and religious freedom should have been paid, and the native strength and nobility of her character should be able to reassert themselves in a period of renewed growth and reëstablished power and prosperity; a time which we hope and trust has already come.

Portugal, still clinging to the fruits of her explorers' genius, and sturdy Holland, strong in her newly won freedom, were looking not to North America but to Brazil and to the Orient for their opportunities to expand; and the future colony of New Amsterdam was destined to be readily transferred to the English for the sake of greater opportunities to the Dutch East India Company. 
Germany was not yet a maritime power. Loosely compacted under the failing hegemony of the House of Austria, she was upon the threshold of the Thirty Years' War in which the most frightful slaughter and devastation were to destroy her cities, lay waste her fields, reduce her population from thirty millions to twelve millions, and set back her civilization for centuries.

Into that vortex of destruction Sweden also was about to be drawn, and her forces were to be engrossed in the struggle for national existence, so that the hopes of Gustavus Adolphus for a new Sweden, upon the banks of the Delaware, were to fail of fruition, and the Swedish colony in America was to pass with hardly a struggle into the hands first of the Dutch and then of the English.

Prussia was a dependent dukedom. Russia had still three-quarters of a century to wait before Peter the Great was to begin to lead her from semi-barbarism into the ranks of civilized powers. Italy was a geographical expression covering a multitude of petty states.

Of all the peoples of Europe, only the French and the English possessed the power, the energy, the adventurous courage, the opportunity and the occasion, for expansion across the Atlantic. The field and the prize were for them, and for them alone.

Upon the throne of France was Henry the Fourth, the greatest of French kings. In the governing class of Frenchmen, political and religious, were the virile strength, the intellectual acumen, the romantic chivalry, the strong passions, the love of glory, the capacity for devotion to ideals; which were to make possible the rule of Richelieu, the ascendency of Louis the Fourteenth, the political idealists of the eighteenth century, the tremendous social forces whose outbreak in the French Revolution appalled the world, and the armies of Napoleon. 
In England the reign of great Elizabeth had just closed. It was the England of Spenser and Shakspere and Bacon; of Cecil and Raleigh; of Drake and Frobisher. John Hampden and Cromwell and Milton were in their childhood. For four centuries since Magna Charta Englishmen had become accustomed to the assertion of individual rights of the citizen against arbitrary power. Since the repudiation of Roman supremacy over the national church, by Henry the Eighth, three generations had become wonted to the assertion of religious freedom. King James's translation of the Bible was in progress and nearly completed. The deep religious feeling of the Puritan reaction against both Roman and royal Episcopacy that was to cost Charles the First his life and James the Second his throne, had already become a controlling motive among a great multitude of the English people.

From these two countries, each possessed of great powers, each endowed with noble qualities, proceeded the colonists who were to dispute for the possession of America. The French movement was in the main governmental, aristocratic, proceeding from State and Church, designed to extend and increase the power, dominion, and glory of the King, to convert the Indians to the true faith, and to extend over them and over all the lands through which they roamed, and over all who should come after them and take their place, the same iron rule of conformity against which the Huguenots of France were vainly contending. The English movement was in the main popular, proceeding from the people of England who wished to escape either Church or State at home and to find freedom in a new world for the practice of their religion or the pursuit of their fortunes according to their own ideas. Some of the English colonies braved the hardships of exile rather than conform against their consciences to requirements of practice and doctrine which the 
English Church imposed. Some sought for fortune in the New World because the State had so distributed the property and so closed the avenues for advancement in England that they must needs seek opportunities elsewhere if at all.

For centuries the struggles between civil and religious absolutism on the one hand and individual liberty on the other were waged alike in France and in England. The attempt to colonize America came from one side of the controversy in France and from the other side of the same controversy in England. The virtues of the two systems were to be tried out and the irrepressible conflict between them was to be continued, in the wilderness.

For capable and efficient leadership, for far-sighted and comprehensive plans, for clear understanding of existing conditions and prevision as to the future, for conspicuous examples of heroic achievement and self-devotion, the palm must be awarded to the French over their English competitors. There are few chapters in history so full of romantic interest, so compelling in their demands for sympathy and admiration, as the record of the century and a half that began with the wooden fortress of Champlain under the bluff at Quebec, and ended with the fall of Montcalm on the Heights of Abraham.

The world owes many debts to France. Not the least of these is the inspiration the men of every race can find in the noble examples of such explorers as Nicollet and Joliet and La Salle; such leaders as Champlain and Frontenac and Duquesne and Montcalm; and such missionaries as La Caron and Bréboeuf and Marquette. They strove for the execution of a great design, holding hardship and suffering and life of little account, in their loyalty to their religion and their king. With infinite pains they won the friendship of the Indians of the Saint Lawrence and the far Northwest; they carried the flag of France to the mouth of the Missis- 
sippi; they drew a cordon of military posts up the Saint Lawrence, across to the Mississippi, and down to the Gulf, well designed to bar the westward advance of the English colonies, to save the great West for their race, and thence to press the English backward to the sea. Their soldiers were, as a rule, better led, better organized, and moved on more definite and certain plans than the English. Occasionally some born fighter on the English side would accomplish a great deed, like Pepperell at Louisburg, or some man of supreme good sense would bring order out of confusion, as did Franklin and Washington; but as a rule colonial legislatures were slow and vacillating; colonial governors were indifferent and short-sighted; and colonial movements were marked by a lack of that definite responsibility, coupled with power, so essential to successful warfare.

Fortunately for England, between the two parties all along the controlling strategic line from this Lake Champlain to the gateway of the West at Fort Duquesne, stretched the barrier of the Long House and its tributary nations. They were always ready, always organized, always watchful. They continually threatened and frequently broke the great French military line of communication. Along the whole line they kept the French continually in jeopardy. Before the barrier the French built forts and trained soldiers behind it the English cleared the forests and built homes and cultivated fields and grew to a great multitude, strong in individual freedom and in the practice of self-government. Again and again the French hurled their forces against the Long House, but always with little practical advantage. At one time De Tracy, the viceroy, burned villages and laid waste the land of the Iroquois with twelve hundred French soldiers. At another, De La Barr, the governor, with eighteen hundred; at another, De Nouville with two thousand; at another, Frontenac with six hundred; at still another, 
Frontenac with a thousand. Always there came also a cloud of Algonquin allies. Always the Iroquois retired and then returned, rebuilt their villages, replanted their fields, resumed their operations, and in their turn took ample revenge for their injuries.

So, to and fro the war parties went, harrying and burning and killing; but always the barrier stood, and always with its aid the English colonies labored and fought and grew strong. When the final struggle came between the armies of France and England, the French had the genius of Montcalm and soldiers as brave as ever drew sword; but behind Wolfe and his stout English hearts was a new people, rich in supplies, trained in warfare, and ready to fight for their homes. South Carolina, the records show, furnished twelve hundred and fifty men for the war; Virginia, two thousand; Pennsylvania, two thousand seven hundred; New Jersey, one thousand; New York, two thousand six hundred and eighty; New Hampshire and Rhode Island, one thousand; Connecticut, five thousand; Massachusetts, seven thousand. It was not merely the army -it was that a nation had arrived, too great in numbers, in extent of territory, in strength of independent, individual character, to be overwhelmed by any power that France could possibly produce. The conclusion was foregone. A battle lost or won at Quebec or elsewhere could but hasten or retard the result a little. The result was sure to come as it did come.

In all this interesting and romantic story may be seen two great proximate causes of the French failure and the English success; two reasons why from Quebec to the Pacific we speak English, follow the course of the common law, and estimate and maintain our rights according to the principles of English freedom.

One of these was the great inferiority of the Indian allies of the French, and the great superiority of the Indian allies of 
the English; the effective and enduring organization, the warlike power, of the Iroquois, and their fidelity to the "covenant chain" which bound them to our fathers. The other cause lies deeper: It is that peoples, not monarchs, settlers, not soldiers, build empires: that the spirit of absolutism in a royal court is a less vital principle than the spirit of liberty in a nation.

In these memorial days let there be honor to Champlain and the chivalry of France: honor to the strong free hearts of the common people of England; and honor also to the savage virtues, the courage and loyal friendship of the Long House of the Iroquois. 



\section{SAMUEL KIRKLAND: FOUNDER OF HAMILTON COLLEGE}

ADDRESS AT THE EXERCISES ATTENDING THE LAYING OF THE CORNER STONE OF THE NEW DARTMOUTH HALL AND THE VISIT OF THE EARL OF DARTMOUTH TO DARTMOUTH COLLEGE, OCTOBER 26, 1904

The President of the College, in introducing Mr. Root, said:

The relation of Dartmouth College to Hamilton College has been far deeper than may appear on the surface. The relation has been one of a common motive, and as each college has taken its own way it has acted under the impulse of that common motive. I present to you tonight a trustee and benefactor of Hamilton College; and, in presenting him to you, I express the sentiment of every American citizen, that we honor Hamilton College in its graduate, who illuminates every subject in politics upon which he thinks and concerning which he speaks or acts. We fcel that when he puts his hand to any political problem, that problem is solved, not violently, but surely. I present to you the Honorable Elihu Root.

A FTER all the charming, eloquent, and interesting A speeches to which we have listened, I feel like that inmate of an insane asylum who inquired of a visitor passing through his ward if he had a piece of toast about him. The visitor said, "No, I have no toast about me." "I am sorry," said the patient, " that you have not a piece of toast. I am a poached egg, and I want to sit down." But I cannot sit down on my toast without saying something about it.

Few men, either of Dartmouth or Hamilton, know how conspicuous an illustration the two colleges are of that power of transmission which President Eliot has so clearly set before us tonight. In the year 1761, Samson Occom, the Indian student whose brilliant receptivity of education led 
Eleazar Wheelock to give his life to the lines of instruction that ultimately produced Dartmouth College, taking up his life-work, went as a missionary to his own people and established himself among the Oneidas on the banks of the Oriskany as it flows into the Mohawk.

In that year, 1761, Samuel Kirkland, a Connecticut boy, became a student in Eleazar Wheelock's school at Lebanon. There he learned the Indian tongue; there he devoted himself to a like mission with Samson Occom. In the year 1766, that year in which Samson Occom, with Nathaniel Whitaker, was the vogue in London, preaching before princes and nobles and creating a notable interest in the cause of Indian education, - that year, in which he, with Nathaniel Whitaker, was getting from the King his gift of two hundred pounds and making the Earl of Dartmouth the patron and promoter of the new enterprise, Samuel Kirkland followed his friend and became in his turn a missionary to the Oneidas.

Shortly after, came to the same place James Deane, a graduate of Dartmouth in the first class, - a member of the college before the buildings were erected, living in the wilderness and gathering from Wheelock's inspiration the same spirit.

For years these three, the students of Wheelock at Lebanon and at Hanover, labored together with the Oneidas, Samuel Kirkland the leading spirit of the three. Patient, enduring, persistent, through perils of river and perils of forests, amid cruel and savage foes, enduring the heats of summers and the deep snows of winters, living in a log hut, travelling through the vast and trackless wilderness, one by one he gained the friendship and the confidence of those fierce warriors, until he became the friend and the father of them all. War swept to and fro in the valley of the Mohawk; but in due time, when peace had come, when civilization had approached near enough to the wilderness, he in his turn 
put into practice the lessons he had learned from Wheelock and imitated Wheelock's example.

We find him in the year 1792 attending the commencement of Dartmouth, bringing with him the Indian chieftain Onandago; and in that same autumn of 1792 he applied to the newly-formed Board of Regents of the University of the State of New York, at Albany, for a charter for an academy, in which he had enlisted the interests of Alexander Hamilton and the patroon Stephen Van Rensselaer.

The charter was granted, and on the plot of land granted him by the faithful Indians he planted his institution. In the deed of conveyance of the land he expressed his purposes and breathed the liberal and generous sentiments of his preceptor, - so far, so widely different from the sour and narrow characteristics which have too often appeared in New England religious life. He said it was his purpose to establish an academy for the benefit of the young settlements and of the confederated tribes of Indians, " earnestly wishing that the institution may grow and flourish, that the advantages of it may be extensive and lasting, and that, under the smiles of the God of wisdom and goodness, it may prove an eminent means of diffusing useful knowledge, enlarging the bounds of human happiness, aiding the reign of virtue and the kingdom of the blessed Redeemer."

And for more than a century, upon the hillside from which the college spire looks down to the north over the lands granted by the Oneidas to James Deane, and to the south over the lands granted by the Oneidas for the work of Samson Occom, standing on the lands granted by the Oneidas to Samuel Kirkland, across the two ranges of mountains, beyond the Adirondack wilderness, the spirit of Eleazar Wheelock, the spirit that founded Dartmouth and has made Dartmouth what it is, has been doing the same work that the spirit of Wheelock has been doing here. 
The specific purpose of these pious men has apparently failed. The work which they sought to do for the Indian has been of but little apparent effect. The savage tribes they fondly dreamed they could civilize have passed away. But great results, nevertheless, flowed from their work. The five great tribes of the Iroquois were the most formidable warriors and the most highly civilized and advanced Indians of our continent. They occupied a strategic point in the continent of North America. From their homes flowed to the south, the Allegheny, the Susquehanna, the Delaware, and the Mohawk. To the north their waters ran into the Great Lakes and into the Saint Lawrence. Five thousand warriors gathered for the security and the extension of their dominion. They controlled the Indian tribes south to the Carolinas, west to the Mississippi, north to the Lakes and the Saint Lawrence, and east farther than the place where we are now standing. Vital to the success of the American forces in the Revolution was the aid or the neutrality of this formidable band of warriors, - men not merely savages, but with a highly developed political organization, politicians and statesmen; and in the great struggles which ended in American independence these three sons of Dartmouth Kirkland, Deane, and Occom - held the Oneidas firm as a rock to the American cause and prevented the powerful influence of that confederacy from waging war upon Washington and his forces in the rear.

The greatest strategic movement of the Revolution upon the British side was that in which Burgoyne, passing down Champlain and the valley of the Hudson, St. Leger, passing from Lake Ontario to Oneida Lake, through Wood Creek, across the carry, and down the valley of the Mohawk, and Howe, ascending the Hudson, were to concentrate at Albany, cut the confederacy in twain, and defeat its armies in detail. 
It was the work of these sons of Dartmouth in the valley of the Oriskany that held the Oneidas friendly to the Ameriean cause and enabled Herkimer to turn back St. Leger from Fort Stanwix and defeat that branch of the strategy, leaving Burgoyne to fall helpless at Saratoga.

Inscrutable are the dispositions of Providence. Man proposes, but God disposes. King George, giving his two hundred pounds to promote the cause of Indian education, sets on foot an influence which avails greatly to cast down and destroy his dearest hopes of overcoming resistance in America. The Earl of Dartmouth, broad-minded and far-seeing, giving his patronage and assistance to the new enterprise, serves to contribute greatly to the success of that Washington whose blood runs in his own veins and to make his own ancestors among the most illustrious upon the earth. A controversy about the control of a little college in New Hampshire brings the genius of Webster to bear upon the mighty mind of Marshall and produces a decision in the Dartmouth College case which stands as a bulwark of property and the rights of contract, as a bulwark to the national power and the true meaning and force of the American Constitution for all time. The pious impulse of Wheelock, seeking to redress the Indian wrongs suffered in one hundred and forty years of warfare, and to make some recompense for the slaughters, the harryings, and the burnings to which hard necessity compelled our fathers, fails of its purpose at the time, but sets in motion the springs of action that, through the succeeding century, and down to the present day, have animated young Americans in carrying through the length and breadth of a great continent the spirit of his example, the characteristics which he sought to impress upon the Indian tribes; so that eighty millions of people, men with consciences, men with high ideals, men 
of noble purposes, are carrying forward in our day, as they will in the days to come, the cause of justice, of liberty, of righteousness upon earth.

The spirit of Eleazar Wheelock and of Samuel Kirkland, failing of their immediate purpose, is the spirit of the American conscience, the spirit of American progress, the spirit of the American future! 


\title{
THE CENTENARY OF HAMILTON COLLEGE
}

\author{
IISTORICAL ADDRESS AT THE CENTENNIAL CELEBRATION, AT \\ CLINTON, N. Y., JUNE 17, 1912
}

On June 17, 1912, Hamilton College, at Clinton, New York, celebrated the one hundredth anniversary of the granting of its charter. The college grew out of the Hamilton Oneida Academy, founded in $\mathbf{1 7 9 3}$ by Samuel Kirkland, missionary to the Oneida tribe of the Iroquois. The historical address at the centennial of the college was delivered by Elihu Root. Mr. Root's relations to Hamilton Collegc form one of the most interesting chapters in his life. He was born in a house on the college campus, within a stone's throw of the one in which his father, Professor Oren Root, lived and died, and which has since been Elihu Root's summer home. Professor Root graduated at Hamilton in the class of 1833, and was for a number of years the tutor in mathematics; in $\mathbf{1 8 4 7}$ he succeeded Professor Marcus Catlin as professor of mathematics, holding this chair until his death in 1885, - a service of forty-two years. He was not merely a great teacher, he was a botanist, a mineralogist, and a lover of flowers, plants, and trees, and his lawns and garden were the wonder and delight of all the countryside. Elihu Root's older brother, Oren Root, Jr., succeeded his father in the chair of mathematics, and a younger brother was the professor of chemistry at Hamilton College for a brief period before his untimely death.

Elihu Root graduated from Hamilton College in 1864; he was the valedictorian of his class, as his father had been before him. He was chosen a member of the board of trustees of the college in 1883, and is the chairman of the board. Thus appear the peculiarly intimate relations of Mr. Root to his Alma Mater, explaining his deep affection for the institution with which so many of his family were connected, and to whose welfare he has devoted so much care and thought. It has been his custom for many years to walk across the street to the college chapel on the opening day of the fall term, and make a brief impromptu address to the assembled students, - words of encouragement, of suggestion, and of inspiration in the work before them. The returning students have come to antieipate this address from the most distinguished alumnus of the college, as marking one of the red-letter days of their college career. It is much to be regretted that none of these talks have been preserved, for they reveal a side of his life and character quite different from any which appears in his more formal addresses.

The regard which the alumni of Hamilton College have come to feel for Mr. Root was indicated at the Commeneement exereises in 1915, when the overshadowing event at the alumni meeting was the presentation to the college of a bronze bust of Mr. Root by a large group of the alumni. The likeness is excellent and characteristic; the artist was C. I. Pietro. 
Mr. Root's historical address at Hamilton's centennial, which follows, should be read in connection with this brief sketch of his relations to the college. The four addresses here printed reveal Mr. Root's close study of the early history of the educational institutions of New York State and of the Indian tribes of the Iroquois nation, so intimately related with that history through Samuel Kirkland and Eleazar Wheelock.

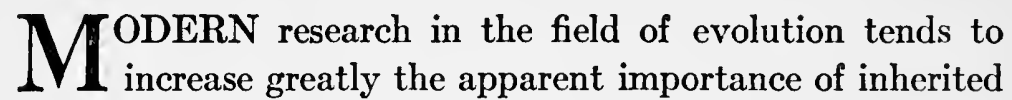
as distinguished from acquired characteristics, in the determination of individual qualities. It appears that from generation to generation the transmission of microscopic determinants fixes, in accordance with established laws already partly discerned, many of the most important characteristics which go to make up the individual. A close analogy may be found in the spiritual succession by which the original qualities and standards of an old institution are transmitted through a long and continually changing series of individual members who differ widely from each other, but who, coming find, and going leave, the institution always essentially the same. Great endowments, stately buildings, public favor and prosperity, cannot produce or take the place of that indefinable and mysterious quality which has been transmitted from a remote past, which has persisted through many changing years and many passing lives, and which gives to the institution a personality of its own, a continuance of the life breathed into it at the moment of its birth. Each new human element that enters into the work of such an institution comes under the domination not of this man or that, but of the potent spirit which gave life to the institution and moulds its traditions, its habits of thought and feeling and action, its purposes and its aspirations.

The true history of such an institution must be the story of the outward working of this informing spirit, and it is only in the origin that we can find understanding of all that follows. 
The granting of the college charter to Hamilton College one hundred years ago was but an incident in the development of an institution already established. The applieation for the charter is described in the Journal of the Regents of the University of the State of New York, at its meeting of February 17, 1812, as -

A petition from the Trustees of Hamilton Oneida Academy praying that the said Academy may be invested with collegiate powers and privileges.

The minutes of the meeting of the regents on March 10, 1812, contained this entry:

The committee to whom was referred the application for a college in Oneida County and that Hamilton Oneida Academy be ereeted into a college, report that, in their opinion, the prayer of the applicants ought to be granted.

The charter, which was reported by Chief Justice Kent at the meeting of the regents on March 22, 1812, begins with the recital:

WHEREAS, The Trustees of Hamilton Oneida Academy, in conjunction with many of the citizens of the Western district of this State, have by their petition made known to us that they, the said applicants, were minded to found a college by engrafting the same on the said Academy at or near the site of said Academy in the town of Paris, in the County of Oneida, and have signified to us that the name thereof shall be Hamilton College.

For the origin of our college we must go back to the beginning of the academy which was thus "invested with collegiate powers and privileges," which was " erected into a college," upon which a college was "engrafted." The beginning of the academy appears in the Journal of the Regents of the University of the State for January 29, 1793. There were present: "His Excellency, the Chancellor of the University (George Clinton); the Vice-Chancellor (John Rodgers); Pierre Van Cortland, Esq., Lieutenant-Governor of this State; Lewis Morris, Benjamin Moore, Philip 
Schuyler, Gulian Ver Planck, Mathew Clarkson" - great names in the history of the state.

The minute reads:

The respective applications of Samuel Kirkland and seven other persons praying that Alexander Hamilton and fifteen other persons for that purpose nominated may be incorporated by the name and style of "The Trustees of Hamilton Oneida Academy " at Whites Town, in the County of Herkimer; and of Joseph Yates and twenty-three other persons praying that Abram Yates, Junior, and twenty-three other persons nominated in the said application may be incorporated by the style of " The Trustees of the Academy of the Town of Schenectady," in the County of Albany, subject nevertheless to be changed into the name of the most liberal benefactor; were severally read and committed to the Vice-Chancellor General Clarkson and Mr. Ver Planck.

The committee named reported favorably at the same meeting, whereupon the minute proceeds:

The Board resolved itself into a committee of the whole to take the above report into consideration, and after some time spent thereon the Chancellor reassumed the chair, and General Schuyler, from the said committee, reported that they had agreed to the report of the subcommittee. Whereupon,

Resolved, That the Board agree to the said report. Ordered, That the Secretary prepare instruments in the usual form for incorporating the said Alexander Hamilton and the said fifteen other persons for that purpose named, and the said Abram Yates and the said twenty-three other persons named in the said application, and that the Chancellor affix the seal of the University to the said instruments.

The "Academy of the Town of Schenectady" subsequently became Union College. Thus Union and Hamilton were created at the same instant by the same sovereign act.

The Hamilton Oneida application upon which this action was taken was dated November 12, 1792. The charter bears the signature of George Clinton as Chancellor. It was one of the early acts of the regents of the University of the State of New York, an institution then recently organized under the statute of 1784, revised and perfected in 1787 upon the report of a committee drafted by Alexander Hamilton. 
The first Board of Trustees appointed by the charter consisted of:

Alexander Hamilton, John Lansing, Egbert Benson, Dan Bradley, Eli Bristol, Erastus Clark, James Dean, Moses Foot, Thomas R. Gold, Sewal Hopkins, Michael Myers, Jonas Platt, Jedediah Sanger, John Sergeant, Timothy Tuttle, and Samuel Wells.

For the true origin of the institution we must go still farther back to the school of Eleazar Wheelock at Lebanon, Connecticut, where came in $\mathbf{1 7 6 1}$ as a student, at the age of ninetcen, Samuel Kirkland, son of the Reverend Daniel Kirkland, of Norwich, Connecticut. The school was established primarily for the education of Indians, and out of it a few years later in 1769 grew Dartmouth College. Here the boy became imbued with the spirit and began to acquire the learning, necessary to qualify him for his extraordinary career of usefulness and power as a missionary to the Iroquois.

After a century and a half of fighting Indians with all the hatred and revenge which follow fire and the sword, outrages and reprisals, the British colonies had become established and strong in their capacity for defense. The long struggle against France and her Indian allies for the control of the continent had drawn to a close with the victories of Wolfe at Quebec and Amherst at Montreal, and a new light seemed to break upon the consciences of the good people of Great Britain and her colonies. The churches that listened every Sunday to the teachings of the Apostles awoke to a sense of concern for the souls of the simple savages whose lands they were taking away and whose habits contact with the new civilization was corrupting. Something of the same missionary spirit arose in Protestant Britain and New England that in the Roman Catholic church had inspired the devotion and sacrifice of the Jesuit missionaries to the Indians of the Northwest, and had raised the names of La Caron and Bréboeuf and Marquette above the obscuring mists of 
doctrinal dissension, above all distinctions of sect and creed, as illustrious and revered examples of Christian service. William Legge, second Earl of Dartmouth, became trustee of a fund collected in England for the support of the school for Indians at Lebanon. The Scotch Society for Propagating Christian Knowledge turned their attention and their money towards the cultivation of the newly-discovered field, sent out missionaries and established other schools for the spread of the gospel. The character and spirit of the Lebanon school are exhibited in the Memorial sent by Mr. Wheelock to Sir William Johnson, superintendent of Indian Affairs in North America, and other commissioners assembled at Fort Stanwix for a conference with the Indians, in October, 1768. The Memorial says:

The Memorial of Eleazar Wheelock of Lebanon in the Colony of Connecticut, Founder and Director of the Indian Charity School in said Colony, humbly showeth:

"That said school was founded with a single view to promote the knowledge of the only true God, and our common salvation especially among the savages of this land; thereby to deliver them from their present miseries, make them good members of society, loyal subjects to our rightful Sovereign, and especially cordial subjects to the King of Zion. And the plan has since been well approved, and the school generously endowed by the liberalities of his present Majesty King George the Third, and by many Noblemen and Gentlemen in Europe, as well as by many charitably disposed people in America - and much labor and cost have been already expended to fit and qualify a number both English and Indians for Missionaries and School Masters among their several tribes who are now or will soon be ready to enter upon their respective services, if suitable doors should be opened for their improvement therein. Some attempts have also been already made among the Oneidas, and not without some encouraging prospect that their lives and manners may be soon formed to rules of decency, civility and religion."

Into this work the young Kirkland entered with unsurpassed energy and enthusiasm. The first reference to him which I find is in a letter from Sir William Johnson to Mr. Wheelock, dated November 17, 1761, in which the writer says: 
Kirkland's intention of learning ye Mohawk language I mueh approve of as after acquiring it he could, when qualified, be of vast serviee to them as a clergyman, which they much want and are very desirous of having.

In the autumn of 1762 Kirkland entered the sophomore class of Princeton, where he received his degree in course at the Commencement of $\mathbf{1 7 6 5}$. So eager, however, was he to enter upon his adventurous work that he did not remain for the college commencement, but before the close of the year he withdrew and engaged in an expedition to the country of the Senecas. Mr. Wheelock said of this expedition, in a letter to the Countess of Huntingdon, on May 16, 1765:

A young English gentleman, Samuel Kirkland, I sent last fall to winter with the numerous and savage tribe of the Senecas in order to learn their language and fit him for a mission among them; where no missionary has hitherto dared to venture. This bold adventure of his, which, considered in all the circumstances of it, is the most extraordinary of the kind I have ever known, has been attended with abundant evidence of a divine blessing.

On April 29, 1765, Mr. Wheelock sent through Sir William Johnson an address to the sachems and chiefs of the Iroquois tribes, in which he said:

I thank you for the kindness which some of you have shown to my dear Mr. Kirkland, whom I sent into your country last fall. His heart is bent to do good to the Indians. He denies himself all the pleasure and honors which he might have here among his friends, only to do you good. I hope you will continue your kindness to him, and treat him as my child. I hope God will make him an instrument of great good to the Indians.

"This gentleman," say MeClure and Parish, speaking of Kirkland, in their memoirs of Wheelock,

was, in various respects, peculiarly qualified for the arduous task. He possessed uncommon constitutional strength and vivacity, a mind fearless in danger, a great fund of benevolence, and a heart devoted to the cause of the Redeemer, and zealous for the conversion of the heathen. He traveled among those barbarians unattended, boldly persevered in the good work, and endured trials and encountered dangers which would have appalled a common mind with terror and dismay. Although famine 
spread its horrors around him, and his life was often in danger from some who watched an opportunity to kill him, yet he continued with them more than eighteen months, taught them from the word of life, and acquired a competent knowledge of their language.

In May, 1766, Mr. Kirkland returned from the country of the Senecas and was ordained at Lebanon, and in July he returned to the country of the Iroquois under a commission from the Society in Scotland. The commission ran in these words :

Be it known to all people by these presents, that the Board of Correspondents, in the Colony of Connecticut, New England, appointed and commissioned by the Honorable Society in Scotland for Propagating Christian Knowledge. ... Do authorize, ordain, and appoint the Reverend Samuel Kirkland a missionary among the heathen and ignorant people in North America ... and we do invest the said Reverend Samuel Kirkland with all the powers, immunities, and privileges belonging to a missionary, employed and commissioned by the Corresponding Commissioners of the Honorable Society in Scotland for propagating Christian knowledge; and as the said Reverend Samuel Kirkland goes forth under the protection of their royal charter, it is desired and expected none will presume to molest or disquiet him in the prosecution of his office, but afford him all needful encouragement and assistance therein.

Signed and sealed by order and in the name of the Board of Correspondents, at Lebanon, the nineteenth day of June, A.D. 1766.

\section{Eleazar Wheelock, Secretary.}

At this time he took up his residence in the more central position of the Oneidas, where he was to pass his life and do his work for more than forty years. Abundant evidence has been preserved of the noble and unselfish spirit in which he worked, of his tireless energy, the fortitude with which he endured hardship and suffering, the courage which no poverty or discouragement could daunt, the swift sympathy through which he found his way to the affections of his untutored people, and the commanding influence over them which he acquired. In 1769 a clergyman in Scotland sent him thirty pounds through a New York correspondent, saying that he had " from good authority a most savory account 
of the uncommon labor of love and hardships in his Master's service of the Indian Missionary, Mr. Samuel Kirkland"; and Kirkland said in his acknowledgment of this:

This will be not only the first thirty pounds, but the first thirty shillings, I ever had, that I might in any sense call my own, except a few dollars given me last spring by the liberality of some friends in Boston, to procure books. I have never had any salary since I embarked in this arduous but glorious cause, nor ever asked for one. I have the testimony of my conscience, with four years' experience (notwithstanding the reproach and censure I am obliged to reeeive from the men of the world), that I was not induced to enter this design of Christianizing the heathen from pecuniary motives or worldly views. Dr. Wheelock has supplied me from time to time, as Providence handed in to him.

And at about the same time the Board in Scotland resolved:

The Board, having taken into consideration the eminent services and painful labors of the Reverend Mr. Samuel Kirkland, one of the missionaries employed by Dr. Wheelock among the Indians, and the difficultics he has undergone in the prosecution of that employment, are of opinion that the sum of one hundred pounds sterling be allowed him, to provide himself with necessaries, before he engages in further services.

It is probable that during all this period Kirkland had in mind as a useful agency for civilizing the Indians the establishment of a school, not only because of the impression derived from the Lebanon School and from Mr. Wheelock's example, but from the fact that during their intimate acquaintance Mr. Wheelock himself had entertained the idea of removing his own school to the country of the Iroquois. A letter is preserved from Wheelock to General Amherst, written April 2, 1763, in which he proposes that a grant of land be made -

on the West side of Susquehanna River or in some other place more convenient, in the heart of the Indian country, in favor of this school ... and that the school be an Academy for all parts of useful learning; part of it to be a college for the education of missionaries, interpreters, school masters, etc., and part of it a school to teach reading, writing, etc. Indeed it appears that the establishment of Dartmouth College on the Mohawk instead of at Hanover was at one 
time in contemplation, for at the Indian Congress at Fort Stanwix, in October, 1768, the Reverend Jacob Johnson, one of the missionaries to the Indians, came in behalf of Dr. Wheelock to ask the favor of Sir William Johnson and his associates for a proposal to the Indians, which ran in this way:

Know Ye That Whereas The Reverend Dr. Eleazar Wheelock of Lebanon in the Colony of Connecticut in New England, Minister of Jesus Christ is about to set up a college or Great School for the benefit of the Indians which generous and good design is favored by your Royal Father the King of Great Britain The Earl of Dartmouth together with many wise as well as great and good men, and a place is now searching out whereon to set up said College and many great offers made in lands and monies wherewith to endow said College in several of the neighboring English Governments but no place resolved upon as yet to set up said College.

These are therefore to ask of you Fathers and Brethren if it be your minds and what you would choose to appropriate and devote a certain tract of your land or country for this great and good purpose on or near the Mohawk River or wherever you in your wisdom may think most convenient of such extent and worth as may be sufficient with what monies and other benefactions and charities may be given to endow said College that it may be of a most public and extensive use and benefit to the several nations of Indians.

The outbreak of the Revolution carried Kirkland's activities into a wider field, introduced a new element into his life, and gave broader scope to his vision, for his knowledge of the Indians and his influence over them enabled him to render most signal service in preventing Indian hostilities, and especially in maintaining the friendly attitude of the Oneidas towards the colonists so that the united action of the League of the Iroquois in the British interest was impossible. He was as patriotic as he was pious. He served his country as zealously and effectively as he had served his religion. He became the agent of the colonies among the Indians of all the Six Nations, and for years journeyed up and down through the country attending their councils and 
pleading the colonial cause. He was chaplain to the garrison at Fort Schuyler under a commission from the Continental Congress. He was brigade chaplain of General Sullivan in the campaign of 1779. He became a trusted adviser of the government regarding Indian affairs. He was thrown into intimate relations of friendship and confidence with Washington and Hamilton and Schuyler and Pickering and Knox. After the defeat of St. Clair, when the Iroquois were in danger of making common cause with the western Indians in a bloody war against the new government of the United States, it was Kirkland who, with infinite pains and difficulty, induced a great party of the chiefs and sachems of the Six Nations to go with him to the seat of government at Philadelphia, where a good understanding was reached and their part in the war prevented. In the meantime he had returned to his missionary duties among the Oneidas and had prepared and sent to Timothy Pickering and to the Board of Commissioners in Boston, " a plan of education for the Indians, particularly of the Five Nations." This plan contemplated, in addition to smaller schools, the establishment of an academy in the vicinity of Oneida at which English youth were to be admitted, and a certain number of Indian youth, selected from the different nations of the confederacy, and to be

instructed in the principles of human nature, in the history of civil society, so as to be able to discern the difference between a state of nature and a state of civilization, and know what it is that makes one nation differ from another in wealth, power, and happiness, and in the principles of natural religion, the moral precepts, and the more plain and express doctrines of Christianity.

Timothy Pickering was one of the little group of men whom Washington trusted most. He was then PostmasterGeneral, was soon to become Secretary of War, and afterwards Secretary of State; and he played a great part in the Federal administrations which, under Washington and John 
Adams, set in motion the machinery of the new government under the Constitution. A long document from him containing comments upon Kirkland's plan of education, approving its general principles, suggesting alterations and improvements, gives evidence of the interest he felt in the subject. In 1792 Kirkland went about the execution of that portion of the plan of education which related to the establishment of an academy. He visited New York, conferred with the governor of the state and the regents, and he visited Philadelphia, where he conferred with Washington, Pickering, and Hamilton. Washington, it is said, expressed a warm interest in the institution, and Hamilton consented to become one of the trustees and to afford all the aid in his power. President Fisher, in his semi-centennial address fifty years ago, states the fact that from Hamilton $\mathrm{Mr}$. Kirkland obtained the gift of a lot of land, which realized what in those times was a handsome sum. When the charter had been granted Kirkland proceeded to donate a site to the new institution on the hillside overlooking the valleys of the Oriskany and the Mohawk - a part of the tract which four years before had been conveyed to him by the conjoint action of the Indians and the state in recognition of his services to both. The terms of the conveyance indicate a liberal spirit and an appreciation of the polite side of life which it is pleasant to find surviving after so long experience amid barbarism and hardship. He was founding an institution in a wilderness, surrounded by savages. The nearest approach to civilization was to be found in the rude life of the frontiersmen. Yet he specified in his gift of land that a part was to be used for an ornamental garden. The preamble of the deed has often been quoted, but cannot be quoted too often. It says:

A serious consideration of the importance of education and an early improvement and cultivation of the human mind, together with the 
situation of the frontier settlements of this part of the state, though extensive and flourishing, yet destitute of any well regulated seminary of learning, has induced and determined me to contribute of the ability wherewith my Heavenly Benefactor hath blessed me, towarls laying the foundation and support of a school or academy in the town of Whitestown, and county of Herkimer, contiguous to the Oneida nation of Indians, for the mutual benefit of the young and flourishing settlements in sail county, and the various tribes of confederate Indians; earnestly wishing the institution may grow and flourish, that the advantages of it may be extensive and lasting, and that, under the smiles of the God of wisdom and goodness, it may prove an eminent means of diffusing useful knowledge, enlarging the bounds of human happiness, aiding the reign of virtue, and the kingdom of the blessed Redeemer.

To this foundation were added contributions made from their slender means by many of the inhabitants of the infant settlements of central New York. In the following year, 1794, the academy building was erected and soon after teaching was commenced. The corner stone of the building was laid with great ceremony by the Baron Frederick William von Steuben, Washington's inspector-general, the drill master of the Revolution, the old staff officer of Frederick the Great, whose military experience and loyal constancy through the privations of Valley Forge turned the undisciplined colonial levies into an army capable of Monmouth and Yorktown. Among the forests that were familiar with the silent passage of the savage Indian, along the slopes that looked down upon the bloody battlefield of Oriskany, the war-worn soldier was accompanied to this place where we now stand by a gay and joyous cavalcade in which were two of the daughters of Mr. Kirkland and their escorts, and in which the Clinton Light Horse, Captain George W. Kirkland commanding, was the guard of honor. Cheerful hope and strong faith and lofty purpose accompanied, with propitious omens, the first physical step in the undertaking we now celebrate and promote, after the lapse of a hundred and eighteen years. 
It is plain that the long and strenuous labors of Kirkland in the revolutionary struggle, his companionship with the great men who were freeing and founding the nation, his agency in establishing and maintaining due political relations between the still powerful Indian tribes and the new United States, had changed and developed the view of the young missionary and brought a new element into the scope of his purpose. He was no longer content to convert pagan savages into Christian savages, but was bent upon establishing an agency of civilization which should do its share towards solving the race question of his time and make peace through knowledge and understanding. To the savage prejudice and error and racial hatred against which he and his great companions and leaders had been struggling, he would oppose, in the words of the plan of education, "instruction in the principles of human nature, in the history of civil society, so as to be able to discern the difference between a state of nature and a state of civilization, and know what it is that makes one nation differ from another in wealth, power, and happiness." He would inculcate not the doctrinal theology of any school or creed, but " principles of natural religion, the moral precepts, and the more plain and express doctrines of Christianity." It was this public service of statesmanship which brought to his project the approval of Washington and the coöperation of Hamilton and Pickering and Steuben. So there entered into the birth of the new institution both the spirit of religion in its broadest sense and the spirit of patriotism in its highest development. It was to promote Christian civilization and to promote instructed and wise citizenship. It was not merely that boys might learn grammar and algebra to help them to get on in life, but that among all the crude and unorganized elements of that transition period should arise an influence powerful to expand men's minds and form men's characters for a nobler country and a better 
world. The spirit of the new institution was born of struggle and arduous labor and sacrifice, and noble scorn of ease and luxury, and little eare for wealth and display, and thirst for knowledge, and loyalty to truth, and love for man, and faith in God. When we now, in our generation, do our share towards carrying on the college we are executing the lofty purposes of great and noble men, long since passed away, and entering into a companionship with them.

The life of the institution has been a life of struggle, happy, perhaps, for the preservation of its virtues. It was several years before the funds sufficed to finish the interior of the building of which Steuben laid the corner stone; but before the close of the eighteenth century it had become a flourishing institution. It was visited by President Timothy Dwight in his "Journey to Whitestown" in 1799. He says of it:

This Seminary is already of considerable importance; and contains fifty-two students, of both sexes, under the care of two instructors. The scheme of education, professedly pursued in it, includes the English, Latin, and Greek languages, and most of the liberal arts and sciences. An Academic building is erected for it, eighty-eight feet long, and forty-six feet wide, of three stories, on a noble, healthy eminence, commanding a rich and extensive prospect. It is, however, but partially finished.

In his account of this same journey President Dwight describes Utica as " a pretty village containing fifty houses," and he says, " in 1794 there were but two, and in 1795 but six." It was Dr. Dwight's intention to extend his journey to the western parts of the state, and he proceeded as far as a point which he describes as " Laird's, at the entrance of the Oneida woods." This is the hamlet on the present state highway about two miles and a half north of the college. There he became daunted by the reported difficulties of penetrating the wilderness any farther and turned back. It seems rather a pity that the old academy building which was built in the wilderness with so much pains should not 
have been preserved for its associations, but it was torn down in 1830, although the house built by Mr. Kirkland at the foot of the hill for his home, in 1795, and long known as the Harding house, still remains. In those early days there was but little money in the neighborhood and the academy had but a small part of that. The report to the regents for the year 1804 states the property of the academy to have been:

Academy lot and house . . . . . . . \$3,500

Other real estate . . . . . . . . . . 900

Personal estate ............ 240

Library and apparatus .......... 462

\section{Annual Income}

From the funds . . . . . . . . . . . . 48

From tuition. . . . . . . . . . . . . 494

Teachers' salaries per annum [there were two of them] 604

Average price of board per annum . . . . . 65

Price of tuition per annum . . . . . . 12

And upon this sasis sixty-four students were being instructed in -

Reading and Writing.

English Grammar, Cyphering, etc.

Mathematics, Bookkeeping, etc.

Dead Languages.

Logic, Rhetoric, Composition, etc.

Moral Philosophy, etc.

The French Language and Natural Philosophy.

When we consider those days of poverty we should remember that the men who contributed the funds and the labor, who cut and squared the timbers and split the shingles and raised the frame for the new academy, were themselves living in $\log$ houses and destitute of what would now be regarded as almost the nece ities of life; that the money which paid the sixty-five dolla s per annum for board and the twelve 
dollars per annum for tuition was hardly earned on partly cleared farms and was saved by self-denial and sacrifice. Life was hard and stern. For a long time after the college charter the students arose in the morning at half past five o'clock, summer and winter, attended prayers in the chapel at six, and recitations until seven, by the light of tallow candles. They attended church and chapel and recitation in rooms without fires, and even the president sometimes preached in overcoat and mittens.

Great progress was made from this point to the opulence which justified and secured the college charter of 1812. In 1814, the regents of the University reported, of the three colleges which then existed in the state:

From Columbia, Union, and Hamilton Colleges, special representations of their respective conditions have been made to the Legislature, by which the degree of increasing prosperity in each will be seen, and how far the very great benefits they are calculated to afford to the community, recommend them to the unremitted support of Government.

And thereupon the legislature of the state enacted a law which affords an interesting illustration of the changing standards of public sentiment and public policy. It was Chapter 120 of the Laws of 1814, entitled "An act instituting a Lottery for the promotion of Literature and for other purposes," passed April 13, 1814. The act recites:

Whereas well regulated seminaries of learning are of immense importance to every country, and tend especially, by the diffusion of science and the promotion of morals, to defend and perpetuate the liberties of a free state; Therefore,

Be it enacted by the people of the State of New York, represented in Senate and Assembly, That thereashall be raised by lottery, in successive classes, a sum equal in amount to the several appropriations made by this act, together with the simple interest accruing thereon, till the same shall be raised and paid by the managers appointed to superintend the same.

The act then proceeds to make appropriations of one hundred and seventy thousand dollars out of the avails of the lottery to Union College, forty sousand dollars to 
Hamilton College, to grant the land known as the Botanic Garden in New York to Columbia College, and to authorize the payment of four thousand dollars to discharge the debt of the Asbury African church in the city of New York. In the original edition of the Session laws there is a note under this statute which says:

No bill before the Legislature excited greater interest and attention than this act. Much credit is due to the unwearied exertions of the able and eloquent president of Union College, in procuring its passage.

And there is an appendix to the volume by which it appears that the state, under an act of June 19, 1812, had already given to Hamilton College the sum of fifty thousand dollars, and that the trustees of the late Hamilton Oneida Academy and other individuals had subscribed fifty thousand dollars for the benefit of the college.

The prosperity of the institution continued until in 1823 a boyish prank in which a cannon was exploded in Old South College led to a controversy that left the college almost without students; and for several years it seemed on the verge of extinction. It soon recovered, but before the recovery was complete an active dispute arose upon a proposition to remove the institution to Utica, and the defeat of that proposal led to the resignation of President Sereno Dwight. We should be grateful that the proposal was defeated, for it would hardly have been the same institution if it had been moved, and now, with the railroad and the trolley line and the macadam roads and the automobile, the college is practically a Utica institution. It is nearer to Utica now than New Hartford or Whitesboro was then. The great citizens whose memory Utica cherishes as a part of her civic traditions deemed it a part of their duty as citizens to maintain and promote the interests of the institution which was exercising so beneficent an influence throughout the region of which Utica is the center. The first president of the Board of Trustees of the 
college for many years was General Joseph Kirkland, mayor of Utica. My own memory recalls, with a distinctness peculiar to the vivid impressions of early youth, the appearance of Horatio Seymour and Joshua Spencer and Hiram Denio and Edmund A. Wetmore and Erastus Clark and S. Newton Dexter and William J. Bacon and Thomas W. Seward and Publius V. Rogers as they appeared upon the commencement stage or attended meetings of the trustees. They deemed this to be their college - the college of their home, and injurious distance did not stop the way of their devotion to her interests. That noble and beautiful city is nobler and more beautiful because step by step with the material growth of its entire life have gone the influences of the institution, educating the sons and mingling with the social life of the city. There are worthy successors now to Kirkland and Seymour and Spencer and Denio, and, since the city and the college are drawn closer together in ease of access, they should draw together in sympathy and mutual benefit.

Since the settlement of that vital controversy the college has proceeded with little adventure upon its simple and progressive course. It has gradually enlarged its Faculty and its facilities for instruction; it has made its standards higher and its work more thorough; and it has kept pace with the requirements of the time, in the comfort and convenience and beauty of the many commodious and stately buildings, which, especially under the force and enthusiasm of President Stryker, have succeeded the rude old wooden academy on the edge of the Oneida woods.

It is an interesting fact that although the Corporation of Harvard College had for many years contributed to the support of Kirkland's mission, and his son, John Thornton Kirkland, had become president of Harvard, and although Dartmouth and Hamilton were so closely associated in their source and origin, and although Kirkland was a graduate of 
Princeton, nevertheless the fonce of the old Connecticut associations was so strong that for more than seventy years every principal and teacher in the academy and every president of the college, with one exception, was a graduate of Yale. The one exception was Dr. Penney, who held the office of president for a very brief time, from 1835 to 1839 . The last of the series of Yale graduates was the eloquent Samuel Ware Fisher, who retired from the office in 1866. After him came that scholarly and delightful gentleman, Samuel Gilman Brown, a graduate of Dartmouth; after him, a graduate of Amherst, the gentle and pious Henry Darling. Then we came to our own in the selection of Melancthon Woolsey Stryker, of the class of 1872. He needs no monument yet, but, when he does, circumspice.

No mortal now can inspire me with half the reverence and admiration that $I$ felt for the teachers of Hamilton fifty years ago. There are no better men than they. There never ean be. But I am bound to say that Hamilton is a better college than it was then. Her work is better done and her students are better educated. It is not my purpose in this paper to recount the details of the college life and growth or to enumerate and estimate the men who have been a part of that life. For the men of the first half-century that service was well done by the historical discourse of fifty years ago, and for them all the same thing is done under the admirable practice by which each year there is read an annalist letter from the class fifty years out, a practice which has endured for half a century and ought never to be abandoned.

I wish, however, to say something about the college that can be illustrated by reference to a group of teachers, who were here fifty years ago - my own father, Oren Root, and his son, Oren Root, who, in succession, filled the chair of mathematics in the college for fifty-eight years; Edward North, professor of Greek for forty-eight years; Charles 
Avery, for twenty-five years professor of chemistry; Christian Henry Frederick Peters, the astronomer for thirty-two years in the Litchfield Observatory; and Anson Juld Upson, for twenty-one years professor of rhetorie. Their students doubtless soon forgot the most of what they learned from book and lecture; but their students never could escape the deep and lasting impressions upon their characters, their tastes, and their intellectual methods. These professors were poor as the world goes, but they had a wealth that money cannot create. They loved their subjects and were happy in their work. They rejoiced in the exercise of their powers. They were content with simple pleasures. They filled the atmosphere about them with an enthusiasm for learning and literature. They sought for truth as one who strives in a game. They never talked or thought about money or investments or profits. They took little heed of all those things for which men are striving and wearing out their lives in the market places of a materialistic civilization.

For a boy to live with such men, to be close to them during four of the most impressionable years of youth, to observe and become accustomed to their simple and sincere lives, without money, made happy by the pleasures of the intellect and taste, to get their standards and become impressed by their estimates of the values of life, and to learn enough out of books in the meantime to understand it all - that is an education beyond price.

And this is the true history of Hamilton. Before the coming of the group that I have named, their predecessors running back to the wilderness days did the same. Their successors are now doing the same. It is something that the great university cannot do. With all that the great university gains, it continually loses something with its growth, and this is what it loses - the personal touch and the development of character. It is something that only the small 
college can do, and only the small college with the right spirit. Hamilton does it because the spirit of the founding in the wilderness persists. She has held to the old faith. She has never sought to be a vocational institution. She does not teach men to be lawyers or doctors or clergymen or bankers or farmers. She is an educational institution. She seeks to develop, to train, to form, to educate, youths to be men competent to fit themselves for any vocation. She has been kept true by her traditions, by the train of simple farmer boys who have come plodding over the hills to her examinations, by the great proportion of her students, who come not because they are sent or because it is the correct thing to do, but because they are eager to make their way in the world. The college has grown, the buildings are more numerous and expensive, the physical appliances are more adequate, the endowment is more ample. The pathetic little schedule of property of a century ago has long since passed the million mark. But all these things are of minor importance, for what would it profit the college to gain them and lose its own soul? The richest possessions of the institution are the multitude of lives, past and present, that would never have been educated if the college had not been here; the intelligences that would not have been enlarged by learning and literature; the spirits that would not have been quickened but for her; the unrecorded influences for the betterment of a thousand communities to which her graduates have gone; the part she has played in the development of our country along lines of Christian civilization. The great thing to be said, as we review the century, is that the college always has been, in its essential character, the same institution which drew its life, in the wilderness, from the struggles and sacrifices of Kirkland - always inspired by the same spirit, faithful to the same cause, and working out the same beneficent purpose. 


\title{
ADDRESS AS HONORARY CHANCELLOR OF UNION UNIVERSITY
}

\author{
SCHENECTADY, NEW YORK, JUNE 10, 1914
}

\begin{abstract}
7 HE first creative act of the regents of the University of 1 the State of New York was on January 29, 1793, in the adoption of a resolution which $I$ will read to you:
\end{abstract}

The respective applications of Samuel Kirkland and seven other persons praying that Alexander Hamilton and fifteen other persons for the purpose nominated may be incorporated by the name and style of "The Trustees of Hamilton Oneida Academy " at Whites Town, in the County of Herkimer; and of Joseph Yates and twenty-three other persons praying that Abram Yates, Junior, and twenty-three other persons nominated in the said application may be incorporated by the style of " The Trustees of the Academy of the Town of Schenectady," in the County of Albany, subject nevertheless to be changed into the name of the most liberal benefactor; were severally read and committed to the Vice-Chancellor General Clarkson and Mr. Ver Planck.

Whereupon (after a favorable report from the committee):

Resolved, That the Board agree to the said report. Ordered, that the Secretary prepare instruments in the usual form for incorporating the said Alexander Hamilton and the said fifteen other persons for that purpose named, and the said Abram Yates and the said twenty-three other persons named in the said application, and that the Chancellor affix the seal of the University to the said instruments.

The Academy of the Town of Schenectady created by this resolution presently became Union College, and then became Union University, and still, like the chambered nautilus, builds her more stately mansions.

The other academy born of the same resolution developed a little later into your neighbor, Hamilton College, and I come, by the kind and partial friendship of your president and trustees, to be your honorary chancellor for this present year, not as a son of Union but as a nephew of Union, a son 
of her twin sister, bound to that sister by birth and parentage and family and personal intimacy through the student body and the faculty and the board of trust, in almost every way by which it is possible for a man to be identified all his life long with an institution. I was brought up there in the great tradition of President Nott. ${ }^{1}$ He was still living and was still president of Union until after my graduation. Among all the college men by whom my boyhood was surrounded, his strong personality loomed large in thought and discussion. His theories and methods of education and discipline were constant subjects of reference and attack and defense. Even the heroes of the Mexican War seemed small in comparison with the eminent man who for more than sixty years gave distinction to Union, as some tall church tower in the distance affects the quality of a landscape.

Fifty years ago and for two full college generations, in frequent passing up and down the valley, I never failed to leave the train and search the long platform of the shabby, little Schenectady station for a boy wearing a Sigma Phi badge. The casual inauguration of a President of the United States was a trifling incident compared with the annual fourth of March convention of that society with the Alpha of New York at Schenectady. The visits of its members to and fro between the colleges brought intimate acquaintance and comradeship and affection and made this old college and the quiet town a part of the memories of our youth always to be graced with a certain tender and romantic sentiment.

Union has always had special respect in my mind as the birthplace of college Greek-letter societies. They must have been a rare set of college boys who, in 1826 and ' 27 con-

1 Eliphalet Nott, Presbyterian clergyman. Born Ashford, Conn., June 25, 1773. Elected president of Union College, now Union University, in 1804, and served until his death, January 29, 1866. By his invention of stoves and other warming apparatus, he acquired a fortune, much of which he devoted to the assistance of Union College. - The Americana Cyclopedia. 
ceived and launched the Kappa Alpha, Delta Phi, and Sigma Phi societies. They must have laid hold of some of the essential and permanent qualities of generous youth for the motif of their new associations, else how could it be that all America followed their example and that almost a hundred years later the oldest men retain affectionate loyalty for the boyish ideals they inspired. They had made Union our Mecca, to which we came with devotion. Many of the founders were still living. To this day my voice grows solemn as I recall the reverence in which they were held. They were our totem bearers; we were their clans. Schenectady was ours because it was theirs. It was to us the place of the miracle. And what wonderful, wonderful boys were their successors in all these societies! How fearless and joyous and debonaire their unquenched youth. How perfect their grace and charm. With what resplendent attire they pervaded the town and shone gloriously against the dull brown background of quaint, sleepy, old Schenectady, in the days before the burial of the dead languages, and the blossoming of the General Electric.

We now live in a different world, with different surroundings, different curriculum, different necessities, different conceptions of education and its purpose. A great army of new sciences crowds Greek and Latin and Pure Mathematics into the corner. We have travelled far from Franklin and his kite to Edison and Marconi; from the comforting dismissal of light, heat, and electricity, as "the three imponderable agents known only by their effects", to the amazing insight and refinement of investigation which proceeds from molecule to atom and from atom to corpuscle, to ion and electron and to the bewildering identification of matter and eternal motion. From vast unknown and unsuspected fields of research and thought, myriads of discoveries, of facts, of generalizations, overwhelm the seeker for knowledge with a 
sense of the impossibility of his task. Rigid selection of the narrow limits and the few subjects which, within the possibilities of a college course, will best subserve the purposes of education has become necessary. Standards of conduct have changed. In Doctor Nott's time they used to fill the soft wood-work in your buildings with a multitude of brads which, concealed under the paint, discouraged the carving of door posts into totem poles, and the devotion of benches to the traditional recreation of the whittling Yankee. I believe that the students of Union have outgrown the occasion for that custom. I suppose the most famous sermon ever preached in the United States was Doctor Nott's sermon against duelling immediately after the fatal meeting between Hamilton and Burr. It was a courageous assault upon a living abuse. I read it over a few years ago and it seemed rhetorical and tame. That dragon was dead. It no longer remains to be slain, and many other dragons have disappeared.

On April 13, 1814, the legislature of New York enacted a law which runs as follows:

Whereas, well regulated seminaries of learning are of immense importance to every country, and tend especially, by the diffusion of science and the promotion of morals, to defend and perpetuate the liberties of a free state; Therefore,

Be it enacted by the people of the State of New York, represented in Senate and Assembly, That there shall be raised by lottery, in successive classes, a sum equal in amount to the several appropriations made by this act, together with the simple interest accruing thereon, till the same shall be raised and paid by the managers appointed to superintend the same.

Among the appropriations made by the act was one of $\$ 170,000$, out of the proceeds of the lottery to Union College, and a foot-note under this statute in the original edition of the laws, says:

No bill before the Iegislature excited greater interest and attention than this act. Much credit is due to the unwearied exertions of the able and eloquent president of Union College, in procuring its passage. 
Imagine President Richmond today proposing to increase the funds of Union by a lottery for the diffusion of science and the promotion of morals, to defend and perpetuate the liberties of a free state! So widely has public policy changed.

The students of Union to whom I am now speaking, compared with the boys whom I knew here in the early sixties, are being educated for different conditions and a different kind of life; for new responsibilities, new duties, new opportunities; and as an honorary chancellor must always be either didactic or cynical, I am moved to make a few remarks about what you are going to do when you leave these side lines and take part in public affairs. You are not to fit yourselves into a scheme or order settled long beforehand. You are to make your own parts in a period of unrest, of changes, some good, some bad, but incessant and universal; of old postulates denied, of old authorities repudiated, and of new conceptions in morals, in government, and in the relations of men in civil society. The old American individualism with its corollaries of individual freedom, independence of character, strict limitation upon the powers of government, development of the state through individual initiative and enterprise is hard pressed by the exigencies of industrial and social organization. Interdependence of life is taking the place of self-dependence. The individual unit in the great factory is powerless as against his employer. The individual unit in the labor union is powerless as against his associates. Organization seems necessary for protection and there is a general and a growing tendency to appeal to that greatest of organizations, the Government to which we all belong, to supply the place of self-protection. Yet increase of government protection involves increase of reliance upon government instead of self-reliance, and it involves also increase of government interference with the conduct of life and the habit of submission to that interference instead of the 
assertion of individual independence. We will all or most of us agree that if this be carried too far, the individual citizens of any country will lose the qualities of character necessary to free self-government.

Democracy here, as in many other parts of the world, is tending to assert its right to the direct conduct of its own affairs. It is tending to cut loose from its old reliance upon representatives chosen to make a special study of law and administration, of public needs and practicable remedies, to consider and discuss and amend and improve projects of law. And it tends to make laws, however complicated, itself by direct action at the polls; to turn out public officers on whatever particular occasion may present itself, to recall judges for unpopular decisions, and to recall or reverse the decisions themselves. More and more democracy is tending to instruct its representatives specifically, and more and more it takes upon itself the determination of the issues of peace and war between nations. Now democracy, with all its virtues, has some weaknesses. It is very common for orators seeking popularity to tell the people how wise and infallible they are, but they who do this are no true friends of the people to whom they speak. Imperfect and erring individuals do not attain absolute perfection by combining with each other. Men in the mass need to guard against their own defects and to be warned of them just as much as individual men. A large part of the faults in government against which the American people for the past few years have been scolding and devising remedies arise from the failure of the American people themselves to perform their own political duties properly. I will mention some of the tendencies against which democracy needs to guard itself:

Popular action is too often guided by feeling rather than by judgment. If one seeks a lawyer to try a cause, or a physician to cure illness, or an engineer to build a bridge, he does 
not make the selection with a view to rewarding some one whom he likes, but he seeks some one who can best do the thing that is to be done - a competent, trustworthy, skillful lawyer or physician or engineer. Yet when some one is to be selected to carry on government, the chances are that the same men will select somebody because they like him; because he is a good fellow and they would like to give lim the salary or the honor of office. Popularity and not competency becomes the test. It is not at all uncommon to see constituencies who are in the main honest and hardworking, return to office year after year absolutely corrupt and dissolute men because they are personally popular, and their constituencies will not listen to any evidence against them. In organizations where many men are coöperating to carry on business in the interests of great numbers of stock and bond holders the rule of fitness for the work to be done as against the rule of popularity is applied without question, and the greater the organization, up to the greatest transportation and industrial organizations, the more rigid is the rule. But when we come to political organization for the purpose of carrying on the business of government in the interests of all the people of a community or a state or a country, the tendency is to reverse the rule. Yet the business of carrying on government is exceedingly complicated and difficult. It requires the highest qualities of intelligence and character if it is to be well done, and, with the continuous enlargement of the functions of government to which I have referred, the requirements of that great business grow every year more and more exacting. Moreover, the good or bad, effective or ineffective, conduct of that business is coming to play a continually greater part in the lives and fortunes and opportunities for success and happiness of all citizens.

There is too general a tendency to take professions of friendship for the people at their face value instead of apply- 
ing to them the tests which men apply in their private lives. Instead of asking how far the self-interest of a professed friend of the people, a desire on his part to make himself popular or to be elected to office, may be the real inspiration of his professions; instead of asking how far his life and established character or the things that he has done furnish evidence of his sincerity, the tendency is to assume that a man has the public interest at heart because he says he has. There seems to be a certain quality of hypnotic suggestion about such declarations as there is about profuse advertising, which, of course, is never accompanied by proof but which sells goods and brings success. This tendency is the stock in trade of the demagogue, and all friends of free self-government have long recognized the great importance that democracies shall outgrow the tendency. I believe that there is and long has been steady progress towards this desirable end. But we are still far from having attained the end.

There is a widespread tendency to regard questions of political conduct, both in the making and in the administration of laws, with exclusive reference to the particular transaction of the moment taken by itself and without reference to the principles or rules of political conduct which ought to govern such action, and without reference to the effect which the action considered may have upon the maintenance and general observance of such rules. To do what seems good or desirable at the time in a particular case without reference to a rule of conduct is what the benevolent despot does. It is what a great many people are doing in Mexico at the present time. It is the very antithesis of the idea upon which our government was built up to be a government of laws and not a government of men. Any political system based upon it rests upon shifting sands.

The American people, in their national and state constitutions, have established certain principles, certain rules of 
right conduct according to which we have all agreed government ought to be conducted - principles and rules for the protection of individual life, and liberty, without which life is not worth having, and property, without which civilization has never yet been maintained. We call these the limitations of the Constitution, and, taken together, we speak of them as the Bill of Rights.

Now no political or governmental action by any congress or legislature or president or governor in any particular case can be so important as the preservation of these great rules of conduct. It may be that from time to time we shall discover that some rule ought to be modified. It may be wrong or it may require change to meet changed conditions or it may be too broadly stated. If so, the change should be made. But that the system of rules as they exist at the time being should be maintained and observed is the most important thing in our self-government. The relation of these rules to our political conduct is the same as the relation of the principles which morality and religion require to be the guide of individual conduct rather than mere impulses or passion.

We practically all agree to this, yet we are all the time forgetting the importance of keeping rules of conduct in mind, and we are apt to be very impatient if the particular thing which we wish to do at a particular time proves to be contrary to a provision of the Constitution. And we are often irritated with the courts who perform the disagreeable duty of reminding us that the action we desire is contrary to the rules of conduct we have resolved to maintain.

Instead of taking an active interest in the general rules of conduct which are to control our political action, there appears to be great indifference to them. There were in round numbers, 1,638,000 votes cast for presidential electors in the state of New York in 1908. In 1914 there were but 306,000 votes cast in the state upon the question whether we shall 
have a convention to revise and amend the constitution of the state; that is to say, disregarding the increase of voting population since 1908, there were this year in the state over $1,322,000$ voters who did not care enough about the constitution of the state to go to the polls and say whether they want to have it changed or left as it is. The same indifference appears in the votes upon amendments to the constitution of this state. During a series of years the aggregate votes for and against various amendments proposed to the people have been in round numbers as follows:

(1899) $469,000,421,000,411,000,460,000$

(1901) 664,000

(1905) 492,000,442,000, 431,000, 472,000, 500,000, 420,000, 413,000

(1907) $490,000,433,000$

(1909) $477,000,527,000,495,000,498,000$

(1910) $664,000,635,000$

(1911) $676,000,620,000,608,000,611,000,629,000,607,000,597,000$, 627,000 .

That is to say, less than a third of the voters of the state took interest enough to express themselves one way or the other regarding constitutional provisions.

This is very natural. People generally are interested in concrete things and personal matters, and the constitution is dull, dry, and uninteresting. It is plain, however, that if a people are going to govern themselves, if they are growing in power and capacity for self-government, there ought to be a progressive increase in the interest which they take in these dry and dull foundations of their political institutions.

Ordinarily the people of the United States take very little interest in their foreign affairs. It is only when a controversy arises which touches some subject of domestic concern that they really wake up to an understanding that there is something real about foreign relations, something besides show and form and ceremony. When they do wake up, the first reaction is on the aggressive side and uncompromisingly in 
favor of the United States always having her own way to the fullest extent in all her dealings with other nations. So long as there is no concrete question directly affecting any American interest we are all in favor of peace and justice, arbitration and kindly consideration, but as soon as a concrete question arises, any suggestion that any other country has rights or that America has obligations which may require a modification of the most extreme possible view of American demands is denounced as an unworthy surrender. Formerly monarchs plunged their countries into war for ambition or personal passion or dynastic aggrandizement, and they made the great mass of their people food for gunpowder. Today it is the general rule that governments are attempting to keep the peace with all the world and the democracies behind them are continually making it difficult for peace to be kept.

\section{Long ago De Tocqueville said:}

Foreign politics demand scarcely any of those qualities which a democracy possesses; and they require, on the contrary, the perfect use of almost all those faculties in which it is deficient. Democracy is favorable to the increase of the internal resources of a state; it tends to diffuse a moderate independence; it promotes the growth of public spirit, and fortifies the respect which is entertained for law in all classes of society: and these are advantages which only exercise an indirect influence over the relations which one people bears to another. But a democracy is unable to regulate the details of an important undertaking, to persevere in a design, and to work out its execution in the presence of serious obstacles. It cannot combine its measures with secrecy, and will not await their consequences with patience. These are qualities which more especially belong to an individual or to an aristocracy; and they are precisely the means by which an individual people attains a predominant position.

These observations are not to be accepted as asserting the ultimate incapacity of democracy in international affairs, but as pointing to imperfections incident to the particular stage of development through which democracy has been passing. The development must go on and a higher degree of capacity for just and adequate treatment of such affairs 
must be reached, or the advent of democracy to immediate control over national foreign affairs will result in a retrograde movement in the relations between nations. For those relations so essential to the progress of civilization rest upon national willingness to be considerate and just.

All of these tendencies against which democracy needs to guard itself and away from which it ought to be growing through its process of development, and many other similar tendencies, may be covered by a single formula.

Democracy always asserts its rights before realizing its duties.

Yet the two are indissolubly united. Each is the necessary corollary of the other. There can be no right which does not impose a duty not merely upon others but upon the very person who possesses the right. And there can be no duty which does not vest a right in the very person who owes the duty. No exercise of political function by any member of a democracy can rightly be a mere matter of personal whim or pleasure. The exercise of the right to vote for a public officer carries the duty to help select an officer who will exercise the powers of his office without oppression and without corruption. The exercise of the right to legislate carries the duty to make laws which will not violate the principles of justice in their operation upon any one in the community. The right to say what course one's government shall follow in an international affair carries the duty to help maintain the peace of the world and justice among nations. These duties are owed by each individual active agent in a democracy and by all of them put together, towards each other individual and all other individuals. Our democracy has hardly yet begun to realize that with every new assertion of its power it assumes an added burden of obligation.

In the very earliest attempts to establish this institution in the year 1780 a college charter was drafted under the 
authority of Governor George Clinton which recited the reason for a college here in these words:

Whereas, a great number of the respectable inhabitants of the counties of Albany, Tryon, and Charlotte, taking into consideration the great benefit of a good education, the disadvantages they labor under for want of the means of acquiring it and the loud call there now is and no doubt will be in a future day for men of learning to fill the several offices of church and state, etc., have petitioned, etc.

To be abreast of our times we must go a step farther than this old eighteenth-century draft charter. I have said these things to you, students of Union, not because there is a loud call for you to hold offices, but because you are a part of the American democracy and because there is a loud call for members of that democracy who will help it grow in realizing the obligations of its power. Many different groups or classes in the population of a country make each its own contribution to the common public opinion and action. The dwellers in the country and in the cities have different points of view. The men who work on the farm, the men who work in the mines, the men who work in manufactories, the men engaged in commerce and transportation, all make their contribution, and in the ultimate result the views of each are modified and corrected by the views of all the others. By reason of your education here you are about to join a great body of men who are fitted to contribute a special element towards the common stock of judgment in our country. The general character of that contribution is indicated by the old term applied to a college course, " a liberal education." That is, "liberal," catholic, expanded, free from narrowness and bigotry in ideas or doctrines, appropriate for a broad and enlightened mind. I do not suppose that you have become very learned here. I do not suppose that you have gone very deeply into any one subject. But one thing has happened to you. You could not stay here four years with- 
out its happening. That is, you have had your horizons pushed back. You have had your vision removed from the little, concrete objects which fill a narrow and isolated life and have been forced to realize, however vaguely, the existence of a vast field of human life and interest; of history and science; of achievement and failure; of examples and warnings; outside of yourselves, beyond the period of your lives and the limits of your homes. You have acquired a bowing acquaintance with lessons of the past and the existence of other lands. You have had lifted for you a corner of the curtain which veils the realm of abstract thought from less favored intelligences. No one of you can have been so indifferent or so dull but that his attitude towards life will be to some degree more liberal, his views of life somewhat broader. The scale of values by which you estimate the little, concrete things and personal happenings of your future experience will perforce be affected by the consciousness that they are all a part of the vast scheme of the developing civilization of the race. Whatever may be your professions or callings, the contribution of each one of you to the life of his time should be the impress of this broader view upon the thought and consciousness of the democracy to which you belong. You should be the advocates of the general rule, the insistent guardians of the principles of action. To refer conduct to principles is the part of large minds, and it is the single path of safety for nations as for individuals. We may differ as to principles. We may be wrong about principles. Never mind. The important thing is to have them, whether we call them religion or morality or honor or justice or wisdom. The one fatal thing is to have none, and to guide the life of a man or of a democracy only by the demands of the particular and the concrete, the impulse and the attraction of the moment. Under the broader view of conduct the time will come when for all our American democracy the sense of duty 
will keep equal pace with the assertion of right. The test of political action will be primarily the effect of a continuous course of such action upon the general welfare. The maintenance of justice will include the willingness to do justice to other men and to other nations, and liberty will mean, not merely liberty for one's own opinions and conduct, but equally the liberty of others in adverse opinions and differing conduct. 



\section{THE HOME OF THE ONEIDAS}

ADDRESS BEFORE THE SOCIETY OF THE SONS OF ONEIDA NEW YORK CITY, MARCH 14, 1903

T OBSERVE that our president has omitted in his enum1 eration the Tribe of Tammany. Is it possible that they alone of all the tribes of the Atlantic Coast failed to tremble when they heard the war-whoop of the Oneidas?

I have just come from the land of the Parting of the Waters. For one whole week I have been living within sight of the house in which $I$ was born and every day looking out over the valleys of the Oriskany and the Mohawk up to the far blue hills of the Royal Grants on the western edge of the Adirondacks; I looked down from the hills to the west of the Oriskany over the field where first floated in the smoke of battle the Stars and Stripes, and where, at the close of that fierce struggle, old Herkimer sat and smoked his pipe as life ebbed away; I looked down on the spires of Utica and Whitestown, at the country which was able to give to the state such men as Henry R. Storrs, Joseph Kirkland, Samuel Beardsley, Green C. Bronson, Hiram Denio, Joshua Spencer, Roscoe Conkling and Francis Kernan; I looked down upon the pathway of empire, upon the path along which dragged the weary way of the wagons that peopled the Great West; on the silvery stream up which were poled the flat boats whose cargoes landed at Fort Stanwix, were transferred to Wood Creek, and so on down to Oneida Lake and Ontario; on the great strategic pathway along which armies have marched and the fate of empire has been decided; at the seat of the power which was dominant in the North American Continent, above all other powers, before the whites asserted 
their supremacy; I lived under the shadow of the walls raised in answer to the pious wish of the missionary Kirkland for the education and the salvation of the children of the Indians with the children of the whites, and which, in response to his Christian hope, gave to the religious faith and education of the country Edward Robinson and Albert Barnes. And now I have come here to see how you have brought from that favored land the power, the resolution, the hardness of fiber and the capacity for labor and for achievement native to the soil of Oneida.

I am glad to see here so many gentlemen from other counties, Mr. President, that they may profit by the influence and the spirit of Oneida. If we can exereise over them the same influence which the Iroquois exercised over the tribes from the sea-coast to the Mississippi we will make better and wiser men of them.

I was led to some reflections during this last visit home. Why is it that the price of farm land in central and northern New York is today, as it is in a large part of New England, less than it was thirty, forty or fifty years ago ? The market is better; farmers have a better opportunity to sell their milk, for I believe they are serving milk from Oneida county to New York today; they have a better opportunity to sell their corn, potatoes, and other vegetables - all the products of the farm, for the canning factory has come almost to the farmer's door, affording a means of preserving and conveying their products to the remotest regions; and still the price of farm land is today less than it was when I was a boy in Oneida county. I suppose it is the trend of population towards the cities. I suppose it results from a comparison between the life of the farmer, with its hard conditions, and its severe labor, and the life which is possible to the young man who goes to the city and embraces a profession or gets into a business. There is a serious side to it. With the twenty- 
five million of people whom we have now in the United States living in cities - indeed, more than that number, I believe, according to the last census - we are facing a new set of conditions in the formation of national character. Life in the city tends to alertness, to activity of mind, to the sharpening of the faculties, but it also tends to a straining and intensity and refinement of the nervous system which will in time make a different race of men. There is much in the old Antaean myth that is true for mankind at large. If the strong man is to continue the race he must continue it in contact with the soil. No body of men who have lived in cities alone can perpetuate themselves as a strong, selfpossessed, self-controlled and dominating race. We must steady the nerves, strengthen the sinews, enlarge and build deep the foundations of body and of morals in our characters by contact with the soil, by the sweetening, steadying, and calming influences of nature, of sky, and tree, and field, and water, if we would continue the American people as the American people were when we were young on the hillsides of Oneida.

We do well to gather here to recall the memories of our old life in our old homes, but the best thing about it will be if it leads some of us back to our old homes; if it leads some of us to reflect upon the wretchedness of the poor boys and girls that are born and bred in city streets, and leads us to take them back where they can have the freedom and the joy of the country. If I were to undertake to repeat the experiment of Ben Franklin, to propose a change in the national bird of America, I would not seek to make it the wild turkey instead of the predatory eagle, but I would say let the homing pigeon be the bird that we imitate.

It is a beneficent provision of nature that as age comes, as the capacity to wrestle in the thick and stress of life's struggle declines, the memories of childhood come up through the 
strata of experience with which middle life has overlaid them; that as one ceases to live in the future because the possibilities of life have become settled and leave no further room for hope, as one ceases to live in the present because the weakness of sinews makes it impossible longer to struggle with the bustling throng, memory goes back to the days of childhood; and the old man lives over again the experiences of youth; and old forms and faces, old scenes of childhood's days, become vivid once again. Happy the man who in his declining years can return in memory to the home to which our hearts turn tonight! How beautiful the green hillsides of the Mohawk! How mighty the river in its flood in the spring! How sweet and clear the bubbling stream of the Oriskany! How glorious and superb the forests of beech and maple in the autumn! How crisp and nerving and strengthening the autumn nights! And, above all, how inspiring the great sweep of the snow field down the sides of the hills and across the broad valleys, thirty, forty, fifty miles away, of pure, unbroken white, except for the dark patches of the hemlock here and there! How cheery the sleigh bells! How sweet the girls we remember! How loud sounds the shout of merry youth! How rings the skate! How swift speeds the sled! How happy were the days we have left behind us in old Oneida! How happy the memories of them that we treasure for our old age! 


\section{JAMES SCHOOLCRAFT SHERMAN}

ADDRESS AT THE MEMORIAL EXERCISES, UNITED STATES SENATE FEBRUARY 15, 1913

On February 15, 1913, the Senate being in session in accordance with a resolution, that the fifteenth day of February be set apart for appropriate exercises in commemoration of the life, character, and public service of the late James S. Sherman, vice-president of the United States and president of the Senate, Mr. Root said:

VICE-PRESIDENT SHERMAN was born in the city of Utica, on the banks of the Mohawk, on October 24, 1855. He came of English stock. His father, Richard U. Sherman, was a native of the same county and was one of its well-known and esteemed citizens. His grandfather, Willett Sherman, was one of the early settlers upon the lands relinquished by the Oneida Indians toward the close of the eighteenth century, and he was one of the first manufacturers of central New York. The grandson was graduated from Hamilton College in the class of 1878. He was admitted to the bar in 1880 and became a successful lawyer. In 1884 he was made mayor of his native city. In 1886 he was chosen by the people of the great manufacturing region of the upper Mohawk to represent them in the Fifticth Congress; and for more than twenty years he continued to represent them, with but one break in his continuous service, through reelection to the Fifty-first, Fifty-third, Fifty-fourth, Fiftyfifth, Fifty-sixth, Fifty-seventh, Fifty-eighth, Fifty-ninth, and Sixtieth Congresses. He became a potent factor in the House of Representatives. He was an active member of the Committee on Interstate and Foreign Commerce; he was chairman of the Committee on Indian Affairs; and he was long a member of the Committee on Rules, one of that little 
group of three constituting a majority of the committee, who, under the former rules of the House, guided the course of legislation and accomplished the nearest approach to responsible parliamentary government which this country has ever seen. Through frequent designation as chairman to preside over the House sitting in Committee of the Whole, where so great a part of the business of the House is done, he gradually rose to a general recognition as a parliamentarian of the first order and a presiding officer of the highest effectiveness.

In Mr. Sherman's home city, as the years passed, evidences accumulated of the respect and confidence in which a community so rarely errs, while it renders unpremeditated judgment upon the character of one known through the contact and observation of daily life. He was made treasurer of his church, the Dutch Reformed Church of Utica, and chairman of its board of trustees. He was chosen to be president of the Utica Trust and Deposit Company. He was made a trustee of his Alma Mater and a member of the executive committee of its board of trust. Children grew up about him and the wife of his youth, in a home where virtue, family affection, cheerfulness, honor, and obedience ruled. It was one of those homes which, indefinitely multiplied among a people, are the safe foundation of just and free self-government, and sure guarantees of the future in a republic. From near and far throughout that region the unfortunate and struggling learned to come to him, their Representative, and his kindness and ready sympathy never failed them. No trouble of another was ever too great or too small to command his attention. His patience under such demands was never worn out. His willingness to take trouble for others was never over-taxed. In the feelings of his people, grateful appreciation of the poor and humble for his kindly service was mingled with general pride in the honor of his representation and of his citizenship. 
The long and distinguished career as a Representative in Congress was brought to a close by Mr. Sherman's election to the Vice-Presidency in November, 1908. He was renominated by his party for the same high office in 1912, but a fatal malady already had been established, and before the election, at his home in Utica, on October 30, 1912, his earthly course came to its end.

Senators know, but few outside of the Senate fully appreciate, how great a service he rendered as presiding officer in this chamber during the three and one-half years which followed the inauguration of March, 1909. Only experience can give a full understanding of the difficulties of legislation, the obstacles to progress in legislative business presented by the persistent advocacy of a multitude of varying opinions, and the impossibility of wise and judicious consideration, when feelings are exasperated and personal prejudices and antipathies are excited. Only through experience can one learn how much the success of legislative consideration depends upon the spirit which pervades the legislative chamber, and how much depends upon the firm and intelligent application of those rules of procedure which the experience of centuries has shown to be necessary in the conduct of legislation. During all the years in which Vice-President Sherman presided over the Senate, we felt the calming and steadying effect of a serene and potent presence in the chair. The justice of his rulings was the product not merely of intellectual integrity, but also of essential kindliness of feeling and consideration. Not only the rulings were fair, but the man was fair. He was strong and self-possessed and untroubled, with a gentle and delicate sense of humor subdued to the proprieties of the place; with a swift certainty of conclusion, founded upon knowledge and accurate thinking, carrying conviction and making acquiescence natural. He expedited business by always doing promptly the right thing without 
vacillation or delay. In the rare instances when he found himself mistaken, prompt acknowledgment and reparation were accorded, with such frank sincerity that the sufferer by the mistake felt himself the gainer. He was positive without dogmatism; certain without personal over-confidence. He controlled procedure under the rules without making them the instruments of irritation or oppression, and without sacrificing the spirit to the letter. Senators of all parties became his friends. All lamented his untimely death, and all join here in doing honor to his memory.

All associated action among men exhibits an inevitable conflict between the idea of combined efficiency and the idea of individual freedom. Neither can prevail without some sacrifice of the other. The difference is temperamental, and the two types of character are hard to reconcile and are prone to misjudgment, each of the other.

Mr. Sherman was of the type which seeks efficiency by the law of its nature. His instincts were for order, discipline, intelligent direction, voluntary subordination to a common purpose, definite conclusions, achievement. So in politics, from first to last, he was always for party organization and party responsibility. In the House he was always for the most effective rules of procedure, and as a parliamentary presiding officer he naturally made the application of parliamentary rules a means of progress rather than an obstacle. His character exhibited in a high degree the virtues of his type. He had the capacity for sympathetic appreciation of the feelings and motives of others which makes associated action easy. He had a genius for friendship which conciliated affection and disarmed enmity. He thought much of the common cause in which he was enlisted, and little of his own advantage; much of general success and little of personal advancement. He was modest and unassuming - never vaunted himself or pressed himself forward. He never 
sought the spotlight on the public stage. He was free from the exaggerated egoism which has wrecked so many fair causes. He had the unselfishness and self-control to obey where others rightly led, and he had the clearness of intelligence, the force of personality, and the decision of character to lead, so that others might follow. He was simple and direct in thought and action. He was frank and truthful and entirely free from that cowardice whieh breeds deception. He had naturally an unconscious courage which needed no screwing to the sticking-point. Among all the multitude who have known him, in boyhood and in manhood, in private and in public life, not one can recall a mean or ignoble or cruel or deceitful word or act on his part. He was sincere in his beliefs, he was faithful to his word, he was steadfast in his friendships, he was loyal to every cause that he espoused. His life made men happier; his example is making men better. His service will endure in the fabric of our institutions.

In this Republic, unlike many nations which enjoy constitutional government, we grant no titles of nobility and no decorations of honor. As public servants complete their work and pass from the stage of action, the judgment of their contemporaries finds no such definite means of expression; and so we have come here today to render in this ceremony the verdict of our generation upon the private virtues and the public service of James Schoolcraft Sherman. The Senate and the House of Representatives, the Chief Justice and the Associate Justiees of the Supreme Court, the ambassadors and ministers of foreign powers, the President and his Cabinet, the civil and military and naval officers of the nation, a multitude of friends who knew him, and of countrymen who knew him not, join here to set in the archives of our Government a record of honor which will remain so long as the nation he served so well shall endure. 



\section{INAUGURATION OF PRESIDENT BROWN}

RESPONSE FOR THE EDUCATIONAL FOUNDATIONS AT THE

INAUGURATION OF DR. ELMER ELLSWORTII BROWN

AS CHANCELLOR OF NEW YORK UNIVERSITY

NOVEMBER 9, 1911

$T^{T}$ is interesting that the name of Elmer Elsworth should 1 come to be the head of the institution which half a century ago was made famous by Theodore Winthrop in Cecil Dreeme.

Notwithstanding the manly and vigorous voice that we have heard this morning from the far distant past, there are not many left under the sun who remember Chrysalis College, in the fine gray old collegiate Gothic building on Washington Square. As I look back to the early sixties and recollect the conditions which existed then, the conditions of the University of the City of New York, of the boys' schools, one called Columbia and one the Free Academy of the City, and look across the long distance of time and see what there is now, I am deeply impressed by the fact that there has been a firm, steady, uniform, progressive development of the educational institutions of our country. There has been much free will for Presbyterianism to lay hold of, but there has been more foreordination imposed by the genius of free government, the natural and necessary development of a free, self-governing people. The multitude of impulses to promote religion, to minister to personal vanity, to advance the fortunes of individuals, to add honor to localities, to promote the development of particular branches of science; all the great variety of impulses which have led individuals to establish educational foundations, have been working out results, quite independent of the purposes and forecasts of 
the individual founders. This myriad of impulses, coming from individual will, has been moulded by the genius of a selfgoverning people into a system out of which gradually are emerging systematic results. It has seemed as if our educational institutions have had little or no policy. Indeed, they have had but little consciousness of an intentional policy. They have been following the course of their destiny, driven on by forces not understood by any man at their head, or even all of them put together.

Gradually we see emerging a differentiation of our educational institutions. The old-fashioned college, the institution, however it may be improved and developed from the germ of the old-fashioned college into the place of training for the whole man to make him ready for whatever comes in life, is a separate class from the vocational institution, broadening and taking in its thousands of students, filling their many separate desires to fit themselves for separate and special vocations in life. Now come the foundations designed for the enlargement of knowledge without immediate and direct relation to the instruction of youth, designed to relieve the men engaged in instruction from the increasing duties of research, represented by the Carnegie Institution of Washington, which is one of the institutions $I$ have the honor to represent here, so that research may be prosecuted, knowledge broadened, and excursions into the field of human possibilities undertaken far beyond the possibility of the institution whose first duty is to teach. As the multitude of the founders has increased, the spirit of the foundation has spread; and while Dr. Brown comes here from the western universities, he comes not from an alien system. The spirit of John Harvard and Elihu Yale and Eleazar Wheelock and Samuel Kirkland and all of that old and honorable list of men, who, centuries ago, devoted their substance and their prayers to the foundation of liberal centers of learning in our coun- 
try, has spread through the multitude of donors, through the army of instructors, until it has permeated the great body of the people, and through all the great West that spirit is interpreted by the people at the polls, who have established the great state institutions and are now sending back their sons and men of their training, to broaden and invigorate the expression of that same spirit in the older institutions. The western state universities of Wisconsin, Michigan, Illinois, California and all the rest, are the same thing that the individual founded long ago in the East, expressed through the multitude who constitute government.

I cannot stop without saying one word of a contribution made to this university by the other educational institution which I represent here today, Hamilton College. Fortyfive years ago, John Norton Pomeroy, of the class of 1847, of Hamilton, was at the head of the University Law Sehool; and he was one of the few men who gave the impulse that has made the university what it is today, a noble, able, devoted, self-sacrificing instructor. A conspicuous illustration of that highest of all functions of the teacher, in that he presented to the young men of his time the spectacle of a life made happy without wealth, without office, without any power except the power of natural sympathy, and with no reward but the joy of continually seeking and finding truth.

Chancellor Brown, I am sure that I can say for all the educational foundations of our state and our country, that you will find in them, in their officers, their friends, and their alumni, that sympathy and support without which no human power avails. In the republic of letters it is especially true that no man gains by the downfall of another. It is all up and none down, because sehools of learning are partieipators in the wealth of all learning. There are no Tripolis in the education of the United States. I extend to you continual sympathy, comradeship, and God-speed. 



\section{THE OBJECT AND THE OPPORTUNITY OF COLUMBIA UNIVERSITY}

ADDRESS UPON THE CONFERRING OF THE DOCTORATE OF LAW, JUNE 8, 1904

At the commencement exercises on its one hundred and fifticth anniversary, June 8, 1904, Columbia University conferred upon Mr. Root its degree of doctor of laws. In presenting Mr. Root for this degree, Professor John W. Burgess said:

You know, sir, and we all know, that as a man and a citizen he is, like the knight of old, without fear and without reproach; that as a lawyer and jurist, he stands in the very forefront of the American bar; that as an orator, he has no superior; and that, as a statesman and an administrator, he has taught his country and the world two great lessons, at least two, one that an American civilian can organize the armed force of his nation more perfectly and more effectively than any purely military man whom that nation has ever produced - demonstrating anew and in a peculiarly significant way the fundamental principle of American polity, that the military power and the military spirit are subordinate to the civil power and the civil spirit; and the other that a free republic can discharge imperial duties successfully and honorably, without sacrificing or impairing or imperilling its own historic liberties.

Mr. President, the highest honors of this university, great as they are, are not too great for such a citizen; and without further commendation, I venture to present to you the Honorable Elihu Root, and to ask for him, at your hands, the degree of doctor of laws of our university.

In conferring the degree, Dr. Nicholas Murray Butler, president of the university, said on behalf of the trustees:

Elihu Root, bachelor of arts of Hamilton College; eminent alike in law and in public administration, trusted counsellor of two Presidents of the United States, to be always remembered in our country's history as foremost in promoting the organization of a sound military system, and in increasing the scope and efficiency of military education, as well as wise, just, and liberty-loving in the government of the nation's wards, I gladly admit you to the degree of doctor of laws in 
this university, and confer upon you all the rights and privileges that belong thereto. In token thereof $I$ hand you this diploma.

At the alumni luncheon on the same day, Dr. John Howard Van Amringe, dean of Columbia College, thus introduced Mr. Root to his fellow-alumni:

Many years ago, nearly half a century, this college added to its responsibilities by establishing a law school. At the head of it was placed an alumnus of Hamilton College, New York, Mr. Theodore W. Dwight, who proved himself a phenomenally able expositor and teacher of law. Not many years ago, the United States added to its responsibilities and entered upon a new enterprise in government requiring profound legal knowledge, wisdom and skill. It also looked to Hamilton College and found among the alumni the man it sought, and committed the undertaking to him. As you all know, he discharged with high distinction the delicate and difficult duties of his great place, and so has written his name large in the history of this country - the Honorable Elihu Root, late secretary of war of the United States, doctor of laws of this university.

Mr. Root responded as follows:

I

$\mathrm{T}$ is peculiarly delightful for me to find myself brought into this fresh relation to this great university, because for many years relations of old personal affection and deep interest have existed between me and it. Long ago a curious interest was excited in my mind by an old statute of our state which coupled in one enactment the college which was my Alma Mater and the then small and struggling college that has become this great university. I wrote down this morning the beginning of that law. It was "An Act instituting a Lottery for the Promotion of Literature, and for other Purposes," passed April 15, 1814, ninety years ago. It began with the preamble: "Whereas, well regulated seminaries of learning are of immense importance to every country, and tend especially, by the diffusion of science and the promotion of morals, to defend and perpetuate the liberties of a free state: Therefore, Be it enacted, that there shall be raised by Lottery" - such and such sums; and the statute then proceeds to make provision out of the sums thus 
raised for Hamilton College, for Union College, and for Columbia College, and for the Asbury African Church in the city of New York. Other days, other manners. . . .

I first knew the college in those days when Professor Torrey's cottage stood on the corner of Forty-ninth Street and Madison Avenue; Professor Joy's cottage on the corner of Fiftieth Street and Madison Avenue; when the college itself was domiciled in the old Deaf and Dumb Asylum in the middle of the block; when the School of Mines had just been established in the basement of the building; and when the institution was presided over by that great educator to whom I am moved to pay honor today, Dr. F. A. P. Barnard, a man who by the infirmity of deafness was cut off from much communication with his fellows and participation in active life, which is deemed essential to successful influence, but whose broad and far-seeing mind mapped out the course which has led to Columbia's greatness. In the enjoyment of the intimate associations with the faculty and of the social life of Columbia in those distant days, I acquired an affection which gives to the diploma that your president has handed to me today a special value, and which will make me cherish it as long as I live. And I learned then, and I have thought a hundred times since of the true and substantial basis of our university. ...

There is a time in life for everything, not only for dance and song. There is a time for initiative and enthusiasm, as there is a time for reason, for conservatism, for caution. The time for initiative, the time for that disregard of consequences which makes men willing to undertake great things, the time when a man can do great things that the mass of men cannot believe to be possible - is the time of youth. It would be a most deplorable thing to make the price of education for Americans the surrender of the years of the greatest initiative and enthusiasm, and of the hope and capacity for great deeds, 
to the work of acquisition alone. Let us keep our boys at work getting knowledge out of books; but not while the enthusiasm of youth is ebbing away and the capacity of doing things is lapsing back behind them. Learning itself is but little. The man who is made is the great thing, and the work of doing is the great thing in the man. Kept too long in academic halls, youth begins to strain and long for the active work of life. Do not let us keep him too long, until that noble and beneficent impulse has passed away.

But it is not the man alone that the university is to make. As age comes and the good and evil of life are counted up, it is universal experience that the question arises: For what good is it all? What to us is the value of life? To what purpose is all the labor and all the effort?

I think that the answer to the question is found in some degree in the positivist philosophy. No man lives to himself. The object of all training, of all education, of all human effort, is not the construction of a single man who dies and is forgotten. The achievements of the day are of little account. Benefits to the community, to the nation, to the civilization, are all that are of value; and the production of the individual man whose influence shall live forever in the weal of humanity - that is the great object of the university, as it is of all human training and of all human effort. Civilization proceeds in its majestic course. The mass of mankind are being lifted up from hard conditions of poverty and ignorance. The participation of the individual man, framed and trained in the University of Columbia in that majestic progress, that is the object of this university. No opportunity has been seen upon earth equal to the opportunity that this university has. Situated in this great city where gather the leaders of thought and opinion, the leaders of science and art, the leaders in all things, the men who are accomplishing great works, material and moral, the men who lead in charity and 
in morals and religion - no university ever had an opportunity to train men and show each one how to do his part towards forwarding the progress of civilization, of humanity, of all that the institutions of our country mean for Americans, equal to that which Columbia has today.

I never pass that old quarter on Madison Avenue, twice rebuilt since I first knew it, without thinking of the beneficent influence the simple, unselfish and noble men who lived there have exercised; and upon this new field, with its splendid buildings and its wide expanse, with all the accessories that wealth can give, with all the influence that capable minds, and learning, and morality, and religion can bring to bear upon the successive ranks of American youth who shall throng its halls - upon this new field, may we not believe that Columbia University will be for many a century to come a source of that lighting and leading of noble character which shall make the great American experiment of justice and liberty not for a few, but for all mankind, however humble the American experiment of government by the people, through the enlightenment of the people, a success to the remotest generations. 



\title{
THE SUPREME TREASURE OF OUR COUNTRY
}

\author{
ADDRESS UPON RECEIVING THE DEGREE OF DOCTOR OF LAWS \\ FROM THE UNIVERSITY OF THE STATE OF NEW YORK, \\ OCTOBER 22, 1915
}

On October 22, 1915, the Regents of the University of the State of New York, at the close of their annual convocation, conferred upon Elihu Root the degree of Doctor of Laws. In conferring this degree, Dr. John H. Finley, the president of the Board of Regents, made the following address:

Mr. Roor: I represent not only all the Regents of the University, but through them the thousands of schools and educational institutions liaving membership in this university and with them the invisible company of the past whose spirits have striven for this great commonwealth, and whose bodies are now of its dust, from Alexander Hamilton, James Duane, George Clinton and John Jay, who had a part in laying the foundations of this state and of this university, even to him who has gone from the living since the meeting only a month ago at which he made the motion to confer this degree upon you - Andrew J. Shipman. Of varying creeds in politics and religion, of dissonant traditions and purposes, they unite in acclaiming the courage, the clarity of vision, nobility of expression, the genius for administration, the unwearying, single-minded devotion to public good, which have given to this state and through this state to the nation, through the nation to the western continent, and through the New World to the Old, one whose recognition gives assurance that in the large freedom of a democracy, the many follow in high undertakings those who are fittest to lead.

In conferring the degree for the state, by the authority of the Regents, I follow the language which was used in the first bestowal of this degrec in 1792 :

Since honor is the reward of merit, and for that reason it is customary in all schools of learning for those who surpass all others in character, talent, and their knowledge of the liberal arts, to be endowed with the greatest praise and the highest honors, we, therefore, the Regents of The University of the State of New York, by the power 
delegated to us by the state, by these presents, desire to bear witness that this honorable and learned man

\section{Elihu Root}

has been exalted to the rank of Doctor of Laws; and that to him have been granted all the rights and privileges that are wont to be conferred either here or elsewhere upon those raised to the high honor of the doctorate.

That this act may have more authority, we have had these letters protected by our common seal this twenty-second day of October, in the year of our Lord one thousand nine hundred and fifteen.

And Mr. Root replied:

W

HAT can I say, except that I am deeply sensible of the great honor conferred upon me in the bestowal of this rare degree by the Regents of the University, that I am most grateful and affected by the too partial friendship which has been exhibited in the recountal of my poor services, and that I shall try, so far as in me lies, to do no dishonor to this great institution?

You are the guardians of the true treasure. It is entrusted to you to see to it that the spirit of those simpler times when the genius of Hamilton outlined the scheme of education, the head of which was to be the University of the State of New York, is not lost. It is due to you, to this great and ancient institution, that the succeeding generations of the children of the state have become the members of a great free commonwealth. It is not so much what they learn, it is not so much what they know, as what they are. Do they love liberty, love it so much that they will accord it to others as well as claim it for themselves? Are they willing to do justice for liberty's sake? Do they love their country and not merely say they love it? Do they rejoice in the prosperity of all Americans? Do they sorrow in the disaster of all Americans? Does the love of liberty and justice in their expanding natures transcend the desire for wealth and station and ease and fame? 
It is for you to answer the question, and upon the answer rests the perpetuity of our free institutions, the life of our country, for from across the Atlantic, among the multitude of lessons that crowd in upon us, clearest of all is the lesson that nations live or die according to the character of their people. Wealth, arms, munitions, discipline, armies, navies, are all splendid services, but the character of the people, the character into which the children are growing, determines the life or death of the nation.

And this, the supreme treasure of our country, in our beloved state is entrusted to you. And if I may hope that this degree is evidence of your belief that in some fair measure I, too, possess that liberal and free and just spirit into which you are training the children of our state, I shall prize it indeed above all other possessions, for that alone is worth the having. All these little things that we do go down the stream and are forgotten, but the building into the structure of the world's freedom, the structure of liberty and order, under justice, of every life, though it be forgotten, is worth the living for. I thank you for numbering me among the pupils of your instruction and the fellows of your spirit. 



\section{THE DUTCH FOUNDERS OF NEW YORK}

ADDRESS AT THE SIXTY-FIRST ANNIVERSARY DINNER OF TIIE SAINT NICHOLAS SOCIETY OF THE CITY OF NEW YORK, DECEMBER 7, 1896

A to be invited to talk to you about your ancestors. That the son of a Yankee from Massachusetts should be permitted to talk about elegant gentlemen from Holland is a privilege. But I find myself confused, sir; I have been perhaps unusually abstemious this evening, and yet I confess myself confused when I find Mayor Strong a Dutchman and Theodore Roosevelt a German and that stout old Dane King Canute an Englishman. I doubt whether I must not join the ranks of my friend Mr. de Peyster and confess myself altogether a lunatic.

For twenty-five years I have listened each year at the dinners of the New England Society to that charming, eloquent and touching speech of Depew's of which he has told us, of how little we have to do and how much you have to do with the establishment of the great American people, - a speech which was in one sense always the same, because it always carried the same truths, but which was always adorned with fresh flowers of fancy, always carried to the heart as well as to the mind, with the most consummate and ever-renewed art of rhetoric and eloquence. For the same long period, I have been studying the sphinx-like character of de Peyster. I have pondered over his silence, the impenetrable reserve with which he has wrapped himself while he has considered the virtues and the achievements of the Dutch, and in thinking of what de Peyster could have said, 
had he been gifted with the power of utterance, I have learned much of what you really are.

I remember, too, one summer afternoon, when in the back garden of one of the old Washington Street houses in the old Dutch town of Schenectady, three boys lay upon the bank looking upon the gently flowing, placid Mohawk, and one of them, then in the pride of beauty of a splendid youth, with opportunities and capacities for a great future, was Douglass Campbell, unfolding the already budding plan of the great work which sixteen years afterwards he gave to the world as an imperishable monument to the achievements of a great race. I feel grieved, Mr. President, that on the Saturday before last Thanksgiving, old Peter Stuyvesant could not have been upon Manhattan Field and have heard the war cry of the tribes who came from about the Fort of Good Hope, to make the last great attack upon the forces from Fort Nassau. How the old man would have stumped up and down the gridiron; with what enthusiasm he would have repelled the suggestion of their war song:

Have you heard about old Eli ?

He has just come to town,

$\mathrm{He}$ is hanging round Manhattan Field

To throw old Nassau down.

Looking for the tiger and he must be found.

And how, when from out the jackstraw combinations of that well-fought field, twenty-two orange-colored legs writhed and waved in final triumph towards Heaven, the soul of Peter Stuyvesant would have shouted to the high and mighty States-General, sitting in high places in another world, the news that the impudent assertion of Governor Nichols, that the Yankees' possession of the North American hemisphere was undisputed, had been laid low and absolutely refuted. 
Thus much of a Dutch partisan I have become by association and by attentive and respectful listening. I must say, however, ungracious though it may be - coming from without and partaking of the nature of a criticism - that two things are undisputed regarding the founders of New Amsterdam. The first is that they were not reformers. They belonged to no City Vigilance League, to no Good Government Club. They came here for trade. They came here for purposes of gain. They came here for no philanthropic object whatever. Nowhere in all this broad world is to be found a better illustration of the wisdom with which Providence works out great and good results from the ordinary operations of human selfishness and the ordinary human capacity for the pursuit of the nimble sixpence, spreading the domain of civilization and fructifying the earth. The other is, that your ancestors met their final downfall and were compelled to surrender their empire into the hands of the English, because of their own criminal conduct. The real cause of the downfall of the Dutch dominion upon this island and in this part of the continent was the crime of the demonetization of wampum. The naked savage they could meet and beat at his own game. No one can say that they were inferior in courage, in devotion and warlike capacity to the Yankees or the Swedes. But the distress, the subordination of the working classes, the paralysis of the body politic, which arose from the control exercised by the plutocracy over that community, and the depreciation of the purchasing power of wampum, was the cause of their utter downfall.

I had some question as to where Mayor Strong got his date of 1655. It seemed to him to be a very significant date in the history of this country. It is the date of the demonetization of wampum. In 1641 a wise and just law was enacted under William the Testy, which provided that until the first of May 
then following, five beads of wampum should be equivalent to one stiver, and that from the first of May and thereafter six beads of wampum should be equivalent to one stiver. Had the community of New Amsterdam opened their mints to the coinage of wampum, without the aid or consent of any other nation, they would still have been the rulers of this city. They abandoned the position they had taken. They allowed the men who lived in fine houses to control them; and in 1655 they gave up that established ratio between wampum and the stiver, and they enacted that eight beads should be necessary to equal one stiver as a legal tender.

The process of demoralization went on. The result was that the Yankees of New England poured their wampum into the mints. They flooded the country with irregular wampum, with wampum made the Lord knows how. The industrious Indians who surrounded Manhattan Island found themselves unable to secure a sufficient amount of the currency in return for their produce. Prices went down, and it was necessary again to change the ratio. Finally they came to the point where they were compelled to provide that twenty-four white beads and twelve black beads of wampum were equal to one stiver. The result was inevitable. They were compelled to demonetize wampum entirely and substitute beaver skins, and that the Yankees cruelly, and perhaps, unjustly, pronounced a skin game. And so they fell an easy prey to Governor Nichols in 1654. But with these few slight exceptions I can say nothing of the Dutch that is not good. The Dutch who came here were brave-brave, sturdy, independent, just, and generous men. That they were brave no one need doubt. No one will conclude from the pages of Washington Irving that life for them was a comic opera. They, as well as my own people on the shores of Massachusetts Bay, had their sufferings and their trials. They had their wars; they had their heroism; they had their 
dangers, and they met them like men. But they were just. The whole history of the colonies proves that they were sturdy, independent men. The very difficulties which aecompanied their whole history shows that. They brought with them from Holland, ingrained in their very nature, the principle of local self-government, and the principal troubles of the colony arose from their unwillingness to submit to dictation from the nineteen at home and from the West India Company and from the States-General. No men upon this continent ever more sturdily, more loyally or more magnificently asserted the right to govern themselves than the staid Dutchmen who came here only for the purposes of gain.

And one other great characteristic I will mention among the many, which if the hour were earlier I would speak of, and that is their wonderful religious toleration. Their great characteristic, the distinguishing characteristic of the Dutch, it seems to me, has always been the sustained, inexpugnable self-poise of their character. Other people are brave; other people are adventurous; other people are law-abiding; other people are just; other people are generous; but that the Dutch people, after their history, after all they suffered in religion's cause, after the terrible trials that they went through, could still be tolerant, is one of the greatest triumphs of the human nature of any race since history began. France has never recovered from the loss of sturdy life which she suffered in the expulsion of the Huguenots after the revocation of the Edict of Nantes. Americans would have suffered in the same degree had the intolerance of my ancestors not been corrected by the open arms and the generous asylum offered by yours, which saved to America the gentle spirits of Ann Hutchinson, of Lady Deborah Moody, of Francis, of Throckmorton, of Nicholson, and of a score of hundreds of others, who, driven by the intolerance of other colonies, 
found here a resting-place and spent their energy, their ability and the efforts of their lifetime in building up this America of ours.

The acknowledgment of all New England is due to that sweet temper, that kindly spirit, that unconquerable selfpoise which enabled the Dutchmen, after all their sufferings, still with open arms to welcome people of all races and all creeds to this asylum of the New World.

The founders of New Amsterdam - who are they? They are the Dutch. Yet more, - if the souls of the dead men live still in their works, they are all the hosts who for all the years that have passed since Peter Stuyvesant laid down the reins of power, have come from every land, from every creed, to help build up this imperial Republic.

They are all the brightest and the best, who from the length and breadth of this great land have come to join in the influences and the achievements of the city which has ever been dominated by the broad, the just, the equal souls of Dutchmen.

Norman and Saxon and Dane are we,

But we are all Danes for thee -

Alexandra

sings the poet. Yankees and Dutch and Southerns are we, and from all the races from over the sea, but we are all Americans for thee - America. 


\title{
JOHN HAY
}

\section{ADDRESS AT THE DEDICATION OF THE JOHN HAY LIBRARY, BROWN UNIVERSITY, NOVEMBER 11, 1910}

John Hay, Secretary of State in the Cabinets of Presidents McKinley and Roosevelt, died July 1, 1905, and he was succeeded July 7 by Elihu Root. Five years after Mr. Hay's death, on November 11, 1910, the library building of Brown University, Providence, R. I., of which Mr. Hay was a graduate, elass of 1858 , was opened to the publie. This library bears the name of John Hay, and was erected in his memory.

The erection of the library had been made possible by a gift of $\$ 150,000$ by Andrew Carnegie, on condition that an equal amount be obtained from others, which was easily secured from twenty-nine persons. It was Mr. Carnegie's suggestion that the building be erected as a memorial to Mr. Hay. A memorial tablet in the entrance hall bears in letters of gold the following inscription:

\author{
IN MEMORY OF \\ JOHN HAY \\ OF THE CLASS OF 1858 \\ POET HISTORIAN DIPLOMATIST \\ STATESMAN \\ WHO MAINTAINED THE OPEN DOOR \\ AND THE GOLDEN RULE \\ THIS BUILDING \\ HAS BEEN ERECTED BY \\ HIS FRIENDS AND \\ FELLOW ALUMNI
}

$\mathrm{H}^{1}$

IGH credit is due to a country that can appreciate such a man as John Hay; that has justly estimated his merit, has valued his service, and honors his memory. A people capable of this have something about them too fine to permit them to be given over to the worship of merely material things. It would be difficult to conceive of a sharper contrast than that between the character of Mr. Hay and the confident, thick-skinned, self-assertive, pushing, hustling character ordinarily associated with success in the practical affairs of this hurly-burly world. The note in his daily life 
which most challenged the attention of an observer was that of extreme refinement, sensitiveness, and reserve. He was unassuming, retiring, self-effacing. He was thoroughly democratic in his sympathies and convictions. He took men at their character value, without regard to place or power or wealth. He was indifferent to popularity, while he was keenly alive to the approval of all those whose judgment he respected and whose friendship he valued. His life was his own and he shared it only with those he loved. He never put it in evidence at the bar of public opinion or entered it in competition for the prizes of public life. The proud modesty of his self-respect made it impossible for him to testify in his own behalf or to allege his own merits. He left others to judge what he was and what he accomplished, without even aid from him, while his generous and loyal nature was never weary of giving credit and praise and honor to his associates and contemporaries to the extreme limit of their deserts.

He was sensitive to beauty in all its forms - beauty in nature, in art, in form of literary expression, in thought, in human character. The principles of Christian ethics controlled his judgments and his practice. A fine and correct taste determined the attractions and repulsions of his life, but he was not narrow or finical. He had the enthusiasm of humanity. He had breadth of view and kindness of judgment. He had the saving grace of humor to a very high degrec, and his humor was exquisite, delicate, and subtle. His estimates of men and their lives cut through all appearances to the realities, were independent of clothes and houses and the accident of manners, and seized upon whatever was true and human, whether it was in the miner's hut or the farmer's ranch or the millionaire's palace. The scope of his human sympathy was universal. He could write both the Pike County Ballads and Castilian Days. Quality appealed to him, whether in an earl or a longshoreman. He had a fine 
sense of proportion and of the fitness of things. He liad imagination, without which no man can be great in business or science or government any more than in literature or art.

The charm of expression that we all find in his writings appeared no less in his conversation. He was the most delightful of companions. One found in him breadth of interest, shrewd observation, profound philosophy, wit, humor, the revelations of tender and loyal friendship and an undertone of strong convictions, and now and then the vibration of intense feeling, and now and then expression of a thought that in substance and perfection of form left in the mind the sense of having seen a perfectly cut precious stone.

His nature had its penalties. He shrank from rude, personal contact. As things fine and noble gave him pleasure, things brutal and sordid caused him pain. He could fight for a cause or a friend, but he shrank from fighting for himself. Everything personally competitive or assertive was distasteful. In his later years the prospect of a public appearance made him positively ill for days before the time arrived.

Under ordinary conditions one would expect such a nature to withhold itself from the practical conflicts of life, to develop the critical faculty at the expense of its dynamic force, and to play its part rather as an observer and commentator than as an actor in the affairs of the world.

There were, however, other elements in this character which forbade such a life. Mr. Hay was born and bred in what was then the rude frontier land of the Middle West. His youth was passed amid the working of the mighty forces that urged on across the prairies and valleys of the continent the most stupendous movement of population since the downfall of the Roman Empire, and that built up and dedicated this republic to freedom. The air he breathed was 
charged with the tense feelings of the Kansas-Nebraska conflict. The indignation, the wrath, the exhortations, the prayers, the stern resolves, the bloodshed and sacrifice, the moral uplifting and sublimation of that great struggle between freedom and slavery were borne in upon this gentle, receptive, and impressionable soul in its unfolding. He returned from his sojourn as a student in the grateful associations of this learned institution to the battlefield of Miltonic conflict in the Lincoln-Douglas debates.

From somewhere in the past, perhaps from Scotland of the Covenant, perhaps from the German Palatinate, harried and ravaged in religious wars, had come a strain of religious feeling and capacity for self-devotion that answered to the influences of this environment. The youth knew Lincoln and became his disciple. During four years in the White House the inspiration and controlling power of that great nature guided the growth of the young assistant secretary. The relation between them was not the ordinary official relation between a great officer and a young assistant. It was personal and affectionate. Often in later times, when Mr. Hay was premier in the Cabinets of President McKinley and President Roosevelt, some incident of service in the White House would recall to his mind events of the earlier days among the same familiar scenes, and the telling of the story with all the charm and graphic power we know so well would leave an impression upon his associates never to be forgotten. One such recital illustrates the relation between the two. Through the center of the second story of the White House runs a long corridor from the extreme east to the extreme west. Mr. Lincoln slept in a room at the western end and the young assistant secretary slept in a little room at the southeastern corner. The President, oppressed and disturbed by the cares and perplexities and nervous tension of the great war, was often sleepless, and often, when he had long sought 
sleep in vain, he would rise and go down to the boy's room and waken him in the dead of night, and, sitting on the edge of his bed, would read aloud to him from some favorite book until the current of thought was changed and sleep seemed possible. Sometimes it was the Bible; sometimes Shakspere; sometimes Tom Hood. The spiritual insight of the great liberator divined in the soul of the boy the sympathy and responsiveness which returned to the reader a calm and solace he could not find in the cold, dull page alone. How often have the listeners to that tale, as their duties brought them again and again to the scene, imagined the tall, gaunt form of Lincoln, clad in white, passing down the long, dimly lighted corridor, seeking comfort against his cares from the sympathy of the noble youth in the thoughts to which he loved to turn. Was ever a boy so fortunate! Was ever a character so influenced and guided in the development of its most impressionable years! From that time we may well believe came the large and kindly view, the deep sense of the seriousness of life underlying the wit and humor and sensitiveness to impressions of the beautiful, the genuine love of his country and its people, the love of humanity, of peace and justice with mercy, the capacity for loyalty to great causes, and the unquestioning realization of duty to play a man's part in the world of action.

Upon this foundation was built up the character that $\mathbf{M r}$. Hay brought to the great office of secretary of state. $\mathrm{He}$ brought also the results of wide and varied training in his maturer years. Five years as secretary of legation in Paris, in Vienna, and in Madrid, two years as assistant secretary of state, service as ambassador to Great Britain, had given him the technique of the profession of diplomacy; had taught him the language of diplomacy, in which words so often have a far different weight and meaning from the same words used in the other professions, at the bar, in business, and in 
literature. He had learned the methods, the conventions, the etiquette, the prejudices, the delicate and difficult art, of diplomatic polemics. He had learned how to avoid the blundering obtuseness to the sentiments and real feelings of others which so often brings to nought the good intentions of well-meaning but uninstructed negotiators, and an occasional illustration of which has suggested the reproach implied in the phrase, "shirt-sleeves diplomacy."

Five years as an editorial writer for the New York Tribune and a considerable period as its responsible editor had broadened his knowledge and interest in the multitude of questions affecting the internal interests of America, and had given him a familiarity with public men and public affairs. His life had been passed among men of thought and men of action. Letters, art, science, business, public life, the professions, had contributed the friendships that enlisted his sympathies. He knew many places and their people; many sides of life; many points of view. He came to the State Department just at the time when the conclusion of the war with Spain opened a new era in the relations between the United States and the other nations of the earth. The establishment of the new relations was important, exigent, and critical. It concerned American prestige and prosperity, the country's place in the estimation of the world, its opportunity for influence for its own good and for the good of mankind. The conjuncture of the time and the man was most fortunate. Mr. Hay impressed upon the diplomacy of the United States at this critical period a quality of courtesy, of consideration, of competency in dealing with diplomatic questions, and a quality of simplicity and truthfulness worthy of the disciple of Lincoln. The little questions that trouble so many small men - petty tricks and deceptions and subterfuges and small advantages - had no place in his scheme of conduct. Always the broad view, the kindly judgment, the considerate 
treatment, the true dignity of nations, the true interests of his people and of civilization, guided his action. We may feel warranted in believing that his administration of our foreign affairs evoked sentiments of respect and friendly judgment throughout the world. The impress of his work and influence will long continue to be a salutary force in the conduct of our foreign affairs.

Among the multitude of things that he did wisely and skillfully we may recall the settlement of the Alaskan Boundary dispute. The rough miners on each side of the disputed line were wholly intolerant of opposing claims and perfectly ready to fight for their own rights, and at any moment a new discovery of gold in the disputed territory might have led to a conflict that would have put all western Canada and western America ablaze. The Joint High Commission of 1898, which was convened for the settlement of a dozen questions between the United States and Canada, came to a deadlock on the Alaskan question and broke up without action. With the greatest good sense and skill, a practical modus vivendi, a judicious treaty, and a tribunal to hear and determine, the difficulty was disposed of forever. The treatment of our relations with England as a neutral during the Boer War; the substitution of the separate and sole ownership of Tutuila for the impracticable condominium which had existed in Samoa; the laying of the foundation for the rescue of Santo Domingo from the condition of anarchy and bankruptcy and the establishment of the system of assistance by the United States which is now making that country peaceful and prosperous; the settlement of American claims against Turkey; the sympathetic treatment of the wrongs against the Jews in Rumania and in Russia; the mediation between Venezuela and her creditors, whose action threatened an infringement of the Monroe Doctrine - all these are entitled to note and to high credit. There were, however, 
three great fields of diplomatic action for which Mr. Hay should always be especially remembered.

He gave vital aid to the definite system for the peaceable settlement of international disputes, which up to this time has been known as the system of arbitration and which received its form in the first Hague Conference of 1899.

The Convention for Arbitration signed at The Hague was purely voluntary in its provisions and it was regarded by most of the European nations as merely sentimental and academic. It was the United States, under Mr. Hay's direction of its foreign office, that led the way in turning this theoretical scheme into a practical working system. The first case taken to the Tribunal was under our treaty with Mexico of May 22, 1902, submitting to its decision the so-called Pious Fund controversy as to the rights of the Roman Catholic Church in California to a portion of the Mexican church moneys, and the first decision of the Tribunal was its decision in favor of the United States in that case.

When in 1903 England, Germany, and Italy had united in a warlike demonstration against Venezuela to compel the payment of her debts, and Venezuela had appealed to the United States for aid, it was under Mr. Hay's guidance that arbitration was substituted for war and the nations were led to the bar of The Hague Tribunal for the determination of their rights.

The real obstacles to arbitration consist not in the difficulty of making speeches about it or in formulating theories in favor of it to which every one will agree, but in the practical working out of the system, the application of the theory to concrete cases. It is the difference between a prospectus and a successful business enterprise. Every one knows that to make a prospectus is easy - to succeed in business is hard. It was in this field of practical difficulty that Mr. Hay came to the rescue of The Hague Tribunal and furnished that ele- 
ment of respect for the Tribunal as a working machine which was necessary to rescue it from exile in Utopia. 'Then he followed with a series of arbitration treaties in which practically all the countries that took part in the first Hague Conference joined in agreement to submit their differences with the United States to The Hague Tribunal. These treaties failed of ratification by the Senate because of a purely internal question, but they furnished the basis of international assent upon which Mr. Hay's successors have been able to give effect to his purposes.

Mr. Hay's diplomacy opened the way for the construction of the Panama Canal. When he took office all progress in that direction was blocked, as it had been since 1850 , by the Clayton-Bulwer Treaty, which bound the United States to Great Britain as a participant in any enterprise for the connection of the two oceans. Upon his negotiation that treaty was abrogated and the United States was set free to accomplish the great work itself. Then followed the negotiations, far advanced towards completion, with Nicaragua; and then the negotiations with Colombia for the right to the Panama route, which culminated in the Hay-Herran Treaty; the negotiations with the French canal company, which ended in the purchase of their rights; the revolution in Panama consequent upon the rejection at Bogota of the Hay-Herran Treaty; the swift and just recognition of the Panama Republic, an act as to the propriety and rightfulness of which Mr. Hay never wavered nor hesitated for an instant. Then came the treaty with Panama; and the work of piercing the barrier, uniting the oceans, changing the trade routes of the world, and fulfilling the dreams of the great navigators was begun.

Mr. Hay led the world in determining the relations of western civilization to the vast empire of China and in preserving the integrity of that empire with an open door of 
equal opportunities for the commerce of the world. When he took office Russia was pressing down upon Manchuria from the north and held possession of the peninsula of the Regent's Sword, with the great fortress of Yort Arthur guarding the entrance to the bay of Chili. England had acquired a lease of Wei-hai-wei for a military and naval base with which to offset Port Arthur, at the same time holding her vantage ground on the south at Hong-Kong, and her sphere of influence covering the entire valley of the Yangtze. France was pressing against the empire with its possession of Tonquin on the southwest; Germany had exacted possession of Kiao-chau and part of the province of Shantung for her vantage ground in the anticipated struggle, and Japan was training her armies and building up her navy across the narrow seas, awaiting her opportunity for her share when the time of dismemberment should arrive. It had come to be tacitly assumed that whatever in China one nation did not take, some other nation would, and so the competition for possession went on. The United States, alone of all the Powers having interests in the Orient, desired no part of China and was free from suspicion of selfish purpose in its affairs. Her position furnished an opportunity of which Mr. Hay availed himself for one of those signal services to mankind which entitle the doer to a place in history. During his first year in the State Department he began the negotiations which resulted in his identic note to the Powers of September, 1899, and culminated in the identic note of July 3, 1900, and the universal assent of the Powers to the policy stated in these words:

The poliey of the Government of the United States is to seek a solution which may bring about permanent safety and peace to China, preserve Chinese territorial and administrative entity, protect all rights guaranteed to friendly powers by treaty and international law, and safeguard for the world the principle of equal and impartial trade with all parts of the Chinese Empire. 
The assent of all the Powers to the principle thus declared was equivalent to a self-denying ordinance barring them from further aggression. A principle of right conduct was established by which all future action was to be judged. Unanimity of assent carried to each Power the assurance that it was safe in conforming its conduct to the principle declared. The process of dismemberment was checked and China's opportunity for regeneration and progress was secured. This was followed by the negotiation of the treaty of October 8, 1903, which at the same time secured larger opportunities for American commerce and laid down the lines for China's rational development. It bound China to abolish the likin - that system of internal customs duties which keeps her provinces apart, impedes trade, and prevents national growth. It provided for uniformity of external duties; for the revision of the mining laws and the development of mineral wealth; for the protection of trade-marks, patents, and copyrights; for a uniform national coinage; and a reform of the judicial system.

In February, 1904, when Russia and Japan were about to make Manchuria the theater of war, it was to Mr. Hay that the Powers turned to secure from both combatants their assent to respect the neutrality of Chinese soil and the preservation of China's administrative entity.

The policies which made possible the construction of the Panama Canal and the open door in China, were but parts of a greater policy, broader in its scope and looking far into the future. They were steps towards the participation of America in the great future of the Pacific. Half a century ago the imagination of William H. Seward was kindled to the belief that, as the commerce of the world had broadened from the Mediterranean to the Atlantic, it was still to broaden from the Atlantic to the Pacific. The correctness of that forecast has become each year more distinct and certain. 
We are just beginning to learn of the enormous mineral wealth of British Columbia, Alaska, Siberia, China. Improvements in transportation and communication are bringing the coasts of that vast ocean nearer together than the shores of the Mediterranean were to the Phœnicians or to the Venetians. The awakening of the Orient to the industrial arts of western civilization is opening vast and indefinite possibilities of new production and consumption. By a long series of apparently unrelated steps, America has been drawn gradually towards her opportunities in this great future. The cession of California, the Oregon treaty, the purchase of Alaska, the annexation of Hawaii, the taking of the Philippines, reveal themselves in retrospeet as successive steps all in the same direction. It remained to construct and control the western avenue of approach to the Pacific through the Isthmus of Panama and to establish in the Orient a standard of respect and confidence for the unselfish purposes and moral power of the government which, with all its faults and shortcomings, still works in the spirit of Washington and Lincoln, and seeks the prosperity of its people in the paths of peace without weakness and of justice with charity. Poetic vision, wisdom of statesmanship, skill of trained diplomacy, have done their work, and the great opportunity of the Pacific lies before our people and their children.

In most of his undertakings Mr. Hay was met with kindness and magnanimous agreement on the part of the Powers with which he dealt. It was so in the Alaska Boundary Treaty; in the abrogation of the Clayton-Bulwer Treaty; in the arbitration treaties; in the general assent to the preservation of the integrity of China. Few of us can realize the long and weary path leading to such a final assent - the difficulties to be overeome; the pitfalls to be avoided; the objections to be answered; the prejudices to be smoothed away; 
the discouragements sufficient to daunt any but the stoutest heart. The international statesman finds in the Powers with whom he deals a response according to the spirit in which he works. Narrow selfishness meets suspicion and distrust. Considerate fairness and the broad views of generous statesmanship meet a response in kind. The spirit of John Hay made it impossible for others to continue narrow and petty in dealing with him; and guided by his sensitive appreciation of the character and feelings of others, made effective by wisdom and skill, that pure and noble spirit achieved a great work for the country he loved. He himself has said:

There are many crosses and trials in the life of one who is endeavoring to serve the commonwealth, but there are also two permanent sources of comfort. One is the support and sympathy of honest and reasonable people. The other is the conviction dwelling forever, like a well of living water, in the hearts of all of us who have faith in the country, that all we do, in the fear of God and the love of the land, will somehow be overruled to the public good; and that even our errors and failures cannot greatly check the irresistible onward march of this mighty Republic, the consummate evolution of countless ages, called by divine voices to a destiny grander and brighter than we can conceive, and moving always, consciously or unconsciously, along lines of beneficent achievement whose constant aims and ultimate ends are peace and righteousness.

I think John Hay would not greatly desire that statues and columns be erected in his memory; that he sought for no monument other than the perpetual existence of the Republic into whose structure he had wrought his life. But we may be sure that this memorial, dedicated to the art of letters, in which he found his solace and refuge from the harsh storms of life, standing amid the scenes that were dear to his memories of youth, inseribed with his name by the proud affection of his Alma Mater, would be inexpressibly grateful to his heart. 



\section{GROVER CLEVELAND}

MEMORIAL ADDRESS AT TIE COLLEGE OF THE CITY OF NEW YORK, MARCH 18, 1909

Grover Cleveland was elected governor of New York in 1882, and was clected the twenty-second President of the United States in 1884. Defeated for reèlection in 1888, he was again elected President in 1892. At the close of his term of office, he removed to Princeton, N. J., where he delivered an annual series of lectures on public affairs before the University, and where he dicd June 24, 1908.

At the memorial exercises, held in New York City, Mr. Root said:

$\mathrm{T}^{\mathrm{T}}$ is a grateful duty to pay public honor to Mr. Cleveland 1 because he was our friend and because all of us are his debtors for his inestimable service to our country.

It is not merely a duty to Mr. Cleveland's memory; it is an opportunity for Americans to signalize their capacity to appreciate such a man as he was.

A nation may be known by the men it honors. All the world honors genius; all the world is dazzled by military glory; all the world is swayed by power of leadership over masses of men; all the world extols great deeds done; but the best evidence of a nation's greatness, the best augury of its power to rise to higher levels of national life, is to be found in the exhibition of general and heartfelt appreciation of a noble character. It is to the honor of America that the deepest, the most lasting impressions from the time of Washington and of Lincoln, are not so much what they did but what they were. Against the background of their arduous labors stand out the men themselves; - the fortitude in adversity, the long-suffering patience, the indomitable will, the strength, the courage, the great-heartedness, the unselfishness, the devotion. The powerful influence of a strong and noble character made manifest in high station, is the chief 
legacy of Grover Cleveland to his countrymen; and it can never be lost, for that influence has greatly moved his generation to higher conceptions of civic duty and independent manhood and public righteousness. Students of political history will remember the many good things he did; but all America has passed a step nearer to its ideals because of what he was.

Grover Cleveland did not rise conspicuously above the men of his time in intellectual power. His mind gave forth none of those emanations of genius which the world admires at a distance and which make their way into the common apprehension only in after years. One of the elements of his strength was that his mind worked as the minds of most Americans work, only more powerfully and conclusively than most minds.

He spoke and wrote distinctly truths that Americans generally were conscious of thinking vaguely. His word, backed by his great authority, and still more potently backed by the example of his life, brought realization of great saving common truths that were being forgotten.

He was a man of convictions, - not extemporized for the moment or for a purpose, but real, vital and urgent. $\mathrm{He}$ thought them out and felt them through and through. His judgments were not the cock-sure opinions of ignorant conceit, but the result of mature deliberation. He gave enormous industry and pains to the processes by which he reached them. He brought to his work strong, practical common sense, a just and well-balanced mind, a temperament of sustained vigor and without malice, sincerity of purpose, and as time went on, ever increasing wisdom and insight into life. His convictions once settled, he was absolutely immovable in them. Neither political expediency nor personal fortunes produced the slightest effect upon his active adherence to them. 
He believed the Silver Purchase Act was ruinous to the country, and he forced its repeal while the politicians of the country, for the most part, were cautiously sounding public sentiment. He considered that the attitude of Great Britain in the Venezuela Boundary controversy put at issue the Monroe Doctrine, essential to our nation's safety, and he unhesitatingly risked the wreck of his Administration and a disastrous war in uncompromising committal to the application of the traditional American policy at all hazards, to that concrete case.

He came to the conclusion that our protective policy was wrong and he risked and lost his reëlection by the tariff message at the close of his first Administration. He was warned of the result by the advisers whom he trusted most, but that produced no effect whatever upon him.

Whether one agrees with his views or not, it is impossible not to find inspiration in the example of the man who would not wait for a safe reëlection to do what he believed to be right. With high and unquestioning courage he stood always for what he believed to be just and honest and best for his country. With unconcealed scorn and wrath, he stood against all sham and chicanery. He was not swayed by personal ambition or by selfishness. He thought always of his work and not of himself.

He was simple and unostentatious in his living. He had no thirst for riches. He was sincere and outspoken without the craft of the time-server or the false pretense of the demagogue. He was kindly and affectionate, - a good husband and father and friend and neighbor.

He remembered always with touching interest the undistinguished companions and scenes of his youth. Great station raised no barriers about his heart. He was loyal to his friends and to his ideals and to every cause in which he had enlisted. 
For a quarter of a century after he was raised to power, in office and out of office, he stood conspicuous before the world, a great figure of exalted citizenship and evidence to all the young men of America that in this free republic the greatest success, high station, power, fame, can be won with truth, honor and self-respect.

To honor him is to be lifted up in spirit; to remember him is to be grateful for our country's happy fortune and to be possessed of a cheerful hope for the future of a people that can bring forth such sons. 


\section{CHESTER ALAN ARTHUR}

ADDRESS AT THE UNVEILING OF A STATUE OF PRESIDENT ARTHUR IN MADISON SQUARE, NEW YORK, JUNE 13, 1899

THE committee of which Mr. Stewart is chairman has 1 charged me with the duty of formally presenting to the city of New York the statue of Chester Alan Arthur, the twenty-first President of the United States, now about to be unveiled.

The statue is the result of the contributions of President Arthur's personal associates and friends here in his home, who knew him as he was, and admired and loved him long before the world knew him, and who found in the universal esteem and admiration accorded to him by the whole people in his later years, not a revelation, but a recognition of his character and qualities. This memorial of our old fellowtownsman is to stand appropriately in the New York of Arthur's day, in the square around which centered so much of the city's activity in his time, in front of the old club house of the Union League, of which he was long an active, and at the last an honorary member, and near the familiar pathway along which so many of us have passed with him on his way to and from his Lexington Avenue home.

The personal relations which have prompted this expression of affection and esteem are rapidly lapsing into oblivion. The men and women who knew him, who felt the direet influence of his clear and bright intelligence, his commanding character, the sweetness and gentleness of his disposition, the rich stores of his cultivated mind, the grace and charm of his courtesy, his grave and simple dignity, and his loyal and steadfast friendship, are passing swiftly away. In but a few 
years more the joy he gave in living, the sharp sorrow of his untimely death, the treasured memories of his association and his friendship, will exist no longer in any human heart. He will be but a name on a page of American history, and his personality, potent as it was in life, living as it is still in our hearts, will have ceased from its separate existence, and live only in the undistinguished immortality of effect in the life of the race. Were this all the story his memory might well be left to die with the dying. But there remains a record of national safety, achieved in a time of imminent peril by his noble qualities, his hard endurance, his self-sacrifice and patriotism; and it is right that this record of patriotic service should be preserved and continually recalled to the minds of generations to come by this statue of imperishable bronze standing upon the public land of the great city which gave him to the nation.

No greater peril ever menaced the constitutional government of the United States than that which confronted the American people when President Garfield fell by the hand of Guiteau on July 2, 1881. External assaults consolidate a people and stimulate their loyalty to their institutions. But when Garfield fell the danger came from within. The factional strife within the dominant party which resulted in the nomination of President Garfield had been of unprecedented bitterness. Vice-President Arthur had been selected from the defeated faction. He was one of its most conspicuous and active leaders. Stilled for a time during the canvass, the controversy was resumed with renewed vigor and more violent feelings in the early days of the new Administration. It extended through every state and city and hamlet. Suddenly the adherents of the murdered President saw the powers of government about to be transferred to the leader of their defeated adversaries, and that transfer effected by the act of an assassin. Many of them could not instantly accept 
the truth that it was the act solely of a half-crazed and disappointed seeker for office; many of them questioned whether the men who were to profit by the act were not the instigators of it. It seemed beyond endurance that Garfield's enemies should profit by his death. Dark suspicions and angry threatenings filled the public mind, and for the moment there was doubt - grave doubt - and imminent peril that the orderly succession of power under the Constitution might not take its peaceful course. Under sueh eonditions, acting upon the telegraphed request of the Cabinet, in order that the first step might be safely passed, Arthur took the oath of office at his home in Lexington Avenue at midnight on the night when Garfield died, and entered upon the solemn duties of the Presidency. Surely no more lonely and pathetic figure was ever seen assuming the powers of government. He had no people behind him, for Garfield, not he, was the people's ehoice; he had no party behind him, for the dominant faction of his party hated his name - were enraged by his advancement, and distrusted his motives. He had not even his own faction behind him, for he already knew that the just discharge of his duties would not accord with the ardent desires of their partisanship, and that disappointment and estrangement lay before him there. He was alone. He was bowed down by the weight of fearful responsibility and crushed to the earth by the feeling, exaggerated but not unfounded, that he took up his heavy burden surrounded by dislike, suspicion, distrust and condemnation as an enemy of the martyred Garfield and the beneficiary of his murder. Deep and settled melancholy possessed him; almost despair overwhelmed him. He went to power walking through the valley of the shadow of death, and ascended the steps of a throne as one who is accused goes to his trial.

Then came the revelation to the people of America that our ever-fortunate republic had again found the man for the 
hour. His actions were informed and guided by absolute self-devotion to the loftiest conception of his great office. The solid substance of character inherited from his Scotch ancestry and his Vermont birthplace, and developed by the typical American training of the poor clergyman's son carving out his own fortune without any resources except those which rested within himself, made him master of himself and dependent only upon the dictates of his own judgment and his own conscience. His skill as a politician in the best sense, and his experience as an administrator, made him a judge of men and their motives, and enabled him to shun the pitfalls which encompass the feet of an unwary executive. His instinctive sympathy and chivalric regard for the memory and the purposes of the lamented Garfield disarmed resentment. The dignified courtesy of his manners and the considerate sincerity of his speech conciliated the friendship even of his enemies. The extremists of his own party faction found that their demands for the fruits of revolution were addressed to one no longer a leader of a faction, but the President of the whole people, conscious of all his obligations, and determined to execute the people's will. The coldness, the alienation of old allies, the reproaches which they visited upon him, he suffered in silence and in sorrow, but with unchanged and steadfast determination. He was wise in statesmanship and firm and effective in administration. Honesty in national finance, purity and effectiveness in the civil service, the promotion of commerce, the re-creation of the American navy, reconciliation between North and South, and honorable friendship with foreign nations, received his active support. Good causes found in him a friend, and bad measures met in him an unyielding opponent.

The genuineness of his patriotism, the integrity of his purpose and the wisdom of his conduct, changed general distrust to universal confidence, reëstablished popular belief in the 
adequacy of our constitutional system in all emergencies, and restored an abiding trust in the perpetuity of our government. He himself greatly aided to make true the memorable words of his first inaugural: "Men may die, but the fabrics of our free institutions remain unshaken."

The strain of that terrible ordeal and the concentrated and unremitting effort of those burdened years exhausted the vital forces of his frame and brought him to the grave in the meridian of his days. He gave his life to his country as truly as one who dies from wounds or disease in war.

With proud and sensitive reticence he had suffered much from calumny. Its completest refutation was the demonstration of what he was. And he was always the same. The noble form of which all America was proud as it bore with dignity and flawless honor the chief magistracy of the greatest of republics was none other than the simple and true American gentleman who walked with us among our homes and to whose memory we offer this poor tribute. 



\section{WILLIAM TECUMSEH SHERMAN}

ADDRESS OF THE SECRETARY OF WAR AT THE UNVEILING OF ST. GAUDENS' STATUE OF GENERAL SHERMAN IN

NEW YORK, MAY 30, 1903

F all the statues with which the affection of friends and the admiration of contemporaries are adorning or disfiguring the public places of the modern world, few will carry any personal meaning to future generations, or serve to perpetuate the memory of the men whom they are designed to honor. The little great men of the hour pass across the stage of the world's life with their generations, and are forgotten. Neither granite shaft nor monumental bronze can confer upon them immortality, or rescue them from the individual oblivion which merges their achievements and their sacrifices into the general progress of the nation and the race.

Rarely, as the centuries pass, some great national crisis, with the inspiration of struggle and the test of requirements beyond the capacity of common men, sifts the material of a nation, and reveals a man equal to a great occasion; whose deeds link his name forever with the decisive events which determine the world's progress, render his existence a fact of historic significance, and make what he was, a part of the common and familiar knowledge of mankind. Such a crisis was the American war for the Union. Such a man was William Tecumseh Sherman. The tremendous consequence to mankind of the decision whether America was to be one nation or a group of small and discordant states, dimly foreseen by the men of half a century ago, even now only begins to be realized by the world, which sees looming large in the horizon of the future the immeasurable possibilities for good or evil in hundreds of millions of people, free, inde- 
pendent, self-governing, with limitless resources, with vital force and energy never surpassed, and united under one government by common institutions, a common sentiment of nationality, and general loyalty to the same ideals.

The part that Sherman played in that great struggle was not merely courageous, loyal, devoted, brilliant. It was essentially decisive. Erase it from the pages of history and no human mind can divine how the blanks would have been filled. No one will dare to say another could have done what Sherman did. Shiloh and Corinth and Vicksburg and Chattanooga and Missionary Ridge crowned him with laurels. The desperate and resourceful campaign which ended in the capture of Atlanta established his place in history as a great commander. The march from Atlanta to the sea, and still on from Savannah northward through the Carolinas, to Raleigh and the surrender of Johnston, ranks among the great and impressive military events of history. But more than all these, in the general maintenance and conduct of the war, the powerful influence of his military genius, the strong support of his indomitable will, the forward impulse of his tremendous energy, the singular nobility of his unselfish character, which, meeting like characteristics in Grant, enabled them to work together like brothers; all these made the personality of Sherman an essentially decisive part of the great consummation which determined that America was to be free and united. We cannot add to his fame; we cannot contribute to his immortality. The statue we raise today can but point future generations to the pages of history where his name and deeds are imperishably recorded. Neither praise can set up nor detraction pull down the immortals in that Valhalla of the truly great where he has taken his eternal place.

But we who knew him living can record our admiration and personal affection. We can tell those who come after us 
that not only was Sherman great but his people loved him. This stern and relentless master of horrid war had a heart as gentle and as tender as a woman's. The veterans who had served under his command came to him in after years as to a father, to find always open his sympathy and his purse. His magnanimous nature accorded a generous meed of praise to every degree of merit exhibited by others associated in his great undertakings. He fought, not urged by ambition or for fame or for fortune, but inspired by loyalty and love of country. Before Sumter was fired upon he declared: "On no earthly account will I do any act or think any thought hostile to or in defiance of the old Government of the United States." And when the great struggle was ended he declared: "War's legitimate object is more perfect peace", and turned with alacrity and gladness to the path of mercy and conciliation. He was a disciplinarian without being a martinet, and his broad sympathies with all his countrymen made him the ideal commander of volunteer soldiers. In peace he was constantly solicitous for the adoption of measures for the future welfare and greatness of his country. He urged on to success the building of the Pacific roads which he foresaw would pacify and civilize the plains and bind together our widely separated seaboards. He founded the Leavenworth School of Military Instruction, and entered actively into the execution of broad and far-seeing plans for utilizing the lessons of the Civil War and improving the military system of the country, until checked and made powerless by a vicious organization which now in this year we are happily bringing to an end. Every good and noble cause found in him encouragement and support. The simplicity and directness of his mind found a counterpart in the fearless frankness of his expression. His conversation and his life taught always the lessons of courage, of hope, of cheerfulness, and of light. He was free from all envy and uncharitableness, 
broad-minded, loyal and generous friend, good and patriotic citizen, honorable gentleman. Again and again he put the Presidency away from him, and chose rather the independence and dignity of citizenship than the honors of high office which could add nothing to his laurels.

Many of us remember the charm and beauty of his declining years; when he had come to the time when men begin to live over in memory the stirring scenes of their youth; when he was wont to seek a familiar corner in the old club-house below us on this avenue - the club formed to support him in the great conflict - and there to discourse with his friends, with quaint wisdom and genial humor and many a brilliant flash of insight, upon the days that were passed. Enjoying life to the end, amid universal respect and affection, secure, in the consciousness of great deeds done, he rested here in peaceful and honored age. It is a fitting and a happy thing that here, too, the genius of the great sculptor who owns this city as his home, should make imperishable by his art this silent witness to the honor that we and our children shall ever pay to Sherman, the soldier, the patriot, and the friend. 


\section{THE GREAT RECONCILIATION}

ADDRESS AT A REUNION OF THE UNION AND CONFEDERATE

VETERANS WHO FOUGHT AT FORT FISHER

UTICA, NEW YORK, SEPTEMBER 9, 1909

T $\mathrm{T}$ is a great pleasure to join with my friends and neighbors $I$ of Oneida County in welcoming to our beautiful city our friends, the enemies of the past, the far distant but never to be forgotten past. I join my voice to those of their old comrades of the Northern forces with a welcome hearty and sincere, in behalf of all our people and in behalf of many who dwell in memory only; for under the magnetic influence of the strong feeling with which these veterans live over the battles of their youth, my mind has been harking back to the memories of my boyhood, when the youth of Oneida County were gathering for their march to the front of the great war. I remember many a bright and beautiful boy, I remember how broken-hearted I was that I was deemed too young and weak a stripling to be of use. I remember how many a noble life was ended, how many a memory is left alone to tell of the forms sleeping beneath the soil of North Carolina, leaving the desolate home among these hillsides. I remember the long years in which the people of the North and the South learned the lesson of patience under affliction, of fortitude, of capacity for sacrifice, of love of country. The spirit of North and South was raised to a purer and a nobler manhood and a greater capacity to make our country take its true place in the vanguard and the march of liberty and justice along the pathway of civilization.

In the names of those who fought and ended their lives, I bid you welcome, friends of the South. It is a great thing to have fought in a great war. It is a great thing to have fought 
in one of the decisive battles of history. It is a great thing to be a part of the structure of a great and noble land; to have fought, not as mercenaries for pay; not to promote some individual ambition; not for plunder; but to have fought for a cause in which one believes, for a cause that lifts up the soul above all selfishness and littleness, above the small things of life, and makes over manhood to last for a lifetime.

Happy men you should be to have crowning your lives this noble wreath of having made the sacrifice of your youth for a great cause in which you believe. Happy men you should be to feel, to know and to be able to see with your own eyes the great country that has risen upon the foundation of that character; not upon the foundation of what you won or lost; not upon the foundation of any town taken or stricken field occupied; but upon the foundation of that character that was built up in those days of struggle and of sacrifice. You are doing, my friends, what your children could not do, for if you had gone to your graves cherishing the bitterness of conflict, their filial piety would have led them to cherish the same bitter and resentful feeling for generation after generation. You alone, you who fought, you who passed the weary days in the trenches, you who had the supreme exultation of life at stake, you alone can render that supreme sacrifice to your country of a gentle and kindly spirit, receiving your former enemies to renewed friendship and binding together all parts of the country for which you both fought. You are doing something far more unexampled than any battle that you won. You are not merely illustrating that nobility of character that came from your birth and your training, but you are illustrating the capacity for self-government that makes America what it is.

For countless generations men have fought and fought bravely. The whole earth is covered with battlefields in which men have given up their lives for great causes and little 
ones and no causes at all. Courage is the rule of mankind. You were brave. Of course you were brave, for you came from stocks that for countless generations had fought for their rights; but other nations have been brave and the lesson of history is that no great nation is made and exists by courage alone. It is only through the possession of moral qualities that lift men above littleness and bitterness and jealousy and envy and pettiness and malice, in peace as in war, that a nation can be great. It is only by the power of kindly and considerate judgment; it is only by the quality of consideration and friendship; it is only by the power of brotherhood, that a nation can govern itself and be great. And you are not only illustrating that capacity for mutual consideration and kindliness that is necessary to patriotism and to the greatness of a nation, but you are teaching it to all of us. In the memory of your great days of youth, of your sacrifices, of the great issues of that time, how small seem the little questions about which we sometimes work so hard and how clear it seems that the only real question upon which the fate of the nation depends, is its capacity to deal with all questions in the right spirit of mutual consideration.

Happy men you should be to have played your part like men, both in the great fight and in the great reconciliation, which no nation on earth ever equaled, ever anywhere or in any age, in the great demonstration of love for country, of capacity for brotherhood among countrymen. And happy you should be to see through these two qualities of courage and fortitude and of capacity for kindly consideration and judgment, your country so great, so noble, doing so great a work, in the forefront of the struggle for liberty and justice and peace throughout the world, a work that more than repays to mankind all the blood that was shed, all the labors, all the sacrifices of your youth, and all the devotion of your manhood to our beloved land. 



\section{THE UNION LEAGUE CLUB}

ADDRESS OF THE SECRETARY OF WAR AT A MEETING OF THE CLUB TO CELEBRATE ITS FORTIETH ANNIVERSARY

FEBRUARY 6, 1903

$\mathrm{T}^{\mathrm{T}}$ is worth while coming from Washington, or even Cali1 fornia, or the Philippines, to receive such a welcome. I will speak tonight for the younger members of the club. Having been a member but thirty-four years, I look up with reverence to these old gentlemen.

Length of life is little, but to have been a part of great affairs, to have done something in this world that will live, to have woven a thread into the fabric that is to last for ages - that is life, that is to have lived, though length of days be short; and that, old friends, you did. We are grateful to you and we honor you for the opportunity which you so nobly seized and upon which you built so well.

Happy men, the men of ' 61 to '65, to live to see the country they saved grown so great, not merely in material things, in manufactories, in railroads, in steamships, and in marble buildings, but so great in all that dignifies and ennobles humanity.

Happy men, to see the great war, which you helped so much to nerve our people to maintain for union and liberty, ended, and the spectacle of noblest manhood exhibited to the world by two sections that had fought so bitterly, coming now together, with the kindliness of true American citizenship, and again together upholding the flag that stands for the liberty of all; to see the curse of slavery removed and the Declaration of Independence made true at last for all our people; to see the reflex action of our institutions upon Europe, gradually changing the structure of governments 
and lifting up across the sea the common people of all the countries of the world towards the dignity of manhood and their rightful participation in the fruits of the earth; to see, what is true, that year by year coming out of the crucible of trial our public service has grown stronger, and purer, and better in its integrity and its devotion to public interests than ever before in all our history; and to see our nation, grown so great and strong, still maintaining the principles of liberty and justice, and stretching out its hands over the weak people of the earth and saying to the oppressors, "Hold."

Happy men, to come out of that time of doubt and trial and see all this. But the end is not yet. Your work was but little if you left none behind you to take it up. The old and trite saying, "Eternal vigilance is the price of liberty", holds a broader and a greater truth, "Eternal good citizenship is the price of good government." There yet remain and there will ever come in unending succession problems, difficulties, doubts, struggles, on which the safety of our institutions will depend. There are today problems almost immeasurable which hold within them the possibilities of evil for our country, calling for the best citizenship, the most devout patriotism, and the hardest fiber. Let me mention two or three.

One is the tendency - growing, I fear - to division between the rich and the poor, under which wealth tends constantly to undue control over legislation, and poverty to stir up a war of classes based upon envy and jealousy of the rich. The very results of our prosperity tend to increase this evil, and every good citizen should set his face against it and seek to make it certain that never in this free land shall we have a war of classes.

Another thing, which is fraught with the most fatal consequences, if it proceeds, is the tendency to check individual enterprise and development. Individual opportunity, the chance that every poor boy has to exercise the talents that 
God has given him and to rise as high as man can go by his brain, by his industry, by his persistency, and by lis courage, is the very foundation of American liberty. Yet many of the labor organizations in this country are including in their rules provisions against the better man doing more work, earning more wages than the man less capable, and seeking to hold down industry, activity, and ambition to the level of sloth, of incompetency, of stupidity. I make no war against labor organizations; I believe in them. I believe that in the great struggle for a fair division of the increased wealth of mankind that comes from the enormous increase of the produetive power of mankind through invention and discovery, the laborer is bound to organize and is entitled to organize, and $\mathrm{I}$ am glad to see him organize and get his own. But we all must set our faces against the tendency to say to any boy, "You shall not do the best you can."

A third thing is one with which this club may well be concerned. Our chairman has referred to the march of the negro regiments down Broadway. Within two years after the foundation of this club the nation, by the Thirteenth Amendment to the Constitution, provided that slavery should not exist in the United States, or in any territory under its jurisdiction. Within five years, by the Fourteenth Amendment, the nation declared that all men born or naturalized within the territory of the United States should be citizens. Within seven years, by the Fifteenth Amendment, the nation declared that no one should be deprived of his right to vote by reason of his race, color, or previous condition of servitude. Those three amendments embodied the scheme adopted by the thoughtful men of the time for the uplifting of those who had been held in slavery from the beginning of our history.

You remember how difficult the question was, What was to be done with the poor black man held all his life a slave 
and now free? The answer, found in these amendments, was, Give him citizenship, give him suffrage, give him equal rights, and he will rise.

I fear we are compelled to face the conclusion that the experiment has failed. The suffrage has been taken away from the black man in most of the states where he composes a large part of the population. The black man of the South, in general, no longer has practically the right of suffrage. The right to aspire to office, however humble, is also disputed, and in a great measure denied.

A curious development has been seen within the past year along this line. President Roosevelt has appointed fewer black men in the South than did President McKinley. There are fewer black men now holding Federal offices in the South than there were when President McKinley died; yet loud outcries are to be heard from the greater part of the South against what is called President Roosevelt's policy of appointing black men to office, whereas under President McKinley, under President Harrison, under President Hayes - under all the preceding Presidents - nothing was said, although more black men were appointed.

A few nights ago a black man, holding an important office, attended an official reception at the White House. There has not been a time since the Civil War when black men have not held similar offices in the Federal Government. At official receptions, the black men holding those offices have always attended. They attended the receptions of Presidents McKinley, Cleveland and the others. Yet the attendance at President Roosevelt's was the signal for an outcry that the whites were being insulted by the appearance of this black office-holder. Now, I am not discussing the question. I am simply showing that the same state of official treatment of the blacks meets a change in the public feeling of the South; that the right to aspire to office under the Federal Govern- 
ment which was formerly unquestioned is now questioned. And it is probably but a matter of time - not so very long a time - when the overwhelming weight of opinion of the white men will succeed in excluding blacks from all offices in the Southern states.

So the country has to face the failure of the plan which was adopted at the close of the Civil War, to lift the blacks from the condition in which they were left when they were freed from slavery by conferring upon them the suffrage. We can never throw off the responsibility that rests on our people for the well-being of these men who were held in bondage for so many generations, and the new question of what can be done for them, now that the first attempt has failed, is one that challenges the best thought and the best patriotism of our country.

But let me say this: You did not live and labor in vain in this field. The spirit in which you wrought still lives. You have created a higher type and sense of patriotism; you have elevated the character of American citizenship; and there live today, largely through your efforts and the example and inspiration furnished by you and the men who labored with you in 1863, men enough in this land, devoted to their country, competent to meet the problems and perform the labors of good citizenship, to carry on the blessings that you saved from extinction to the remotest generation. And to that end, long live the Union League Club! 



\section{THE CITY OF NEW YORK}

REMARKS OF THE SECRETARY OF WAR, AT THE CELEBRATION OF THE TWO HUNDRED AND FIFTIETH ANNIVERSARY OF THE FOUNDING OF ITS MUNICIPAL GOVERNMENT, MAY 26, 1903

HE few words which I have been asked to say on this
interesting occasion need be nothing more than to read a letter which has been placed in my hands by the Mayor from the President of the United States:

White House,

My Dear Mr. Mayor:

Washington, March 20, 1903.

It is with sincere regret that I find myself unable to accept your invitation. I am to be in California on the date you mention. Otherwise, I should have strained every nerve to be present on an occasion so interesting to a native New Yorker who is at the time President of the United States. The changes in New York City during the two hundred and fifty years which have just elapsed are such as could be paralleled nowhere else in the world. We now have in New York the second largest city of the world, and it is no idle compliment to you, and to those associated with you, Mr. Mayor, for me to say that there is now no other city here or abroad of whose governing officials its people have more just reason to feel proud. With regard,

Sincerely yours,

(Signed) Theodore Roosevelt.

It is impossible to think of any municipal celebration which has more national interest than this. It is no mere figure of speech to say, as the orator of the day has said, that this is the gateway of the nation. The municipal government which was established two hundred and fifty years ago upon this island, has borne a burden for the nation, because it has stood at the gateway; because through this portal have come the millions from the old world, here first to learn the lesson of independent manhood, and here first to learn the lesson of 
freedom controlled and subordinated to law. Because this was the gateway of commerce and the center of wealth have come to it from all over this great land the youth - full of ambition and of hope - seeking fame and fortune; have come to it the men who control the great business enterprises of the whole country, that they may be together for business intercourse, rather than remain at the place where the material enterprise is conducted. Here have come the men who have been successful throughout the entire country, to find the means of spending, with the greatest facility and the greatest pleasure, the wealth they have accumulated. The constant growth and the constant shifting of our population - breaking constantly the ties of neighborhood have made it impossible that we should be such a homogeneous people as to render it easy to conduct good government. We have been wrestling here - the municipal government of which you are the head has, during the past half-century of our greatest growth been wrestling, with the most difficult problem of popular government in this world; all because of the functions that the city of New York has performed for the whole people of the United States.

That property and life are protected; that the city still grows and ever grows; that peace and order reign; that more stately palaces rise along our streets; that libraries, and schools, and churches increase and multiply; that treasures of art and of literature accumulate; that the people of the city show capacity to govern themselves - slaves to no ruler and to no party - competent to set up and to pull down their municipal government as they will; that the people of New York respond to every demand of patriotic duty; that the people of New York respond to every demand of humanity; that love for country and love for mankind find in good citizenship and in noble works of charity examples to be surpassed nowhere on earth - we all can testify. And 
the reason is that the men who two hundred and fifty years ago founded this munieipal government were sound and wholesome men, and that their spirit of freedom, of toleration, of civic pride, and good citizenship survives, permeating the whole inereasing mass of the great metropolis. I am proud to come back from the councils of the nation to my own home; proud to be a citizen of New York. 



\section{THE OLD AND THE NEW NEW YORK}

ADDRESS AT A DINNER OF TIIE LOTUS CLUB IN HONOR OF THE SECRETARY OF WAR, NEW YORK, MAY 9, 1903

T AM deeply sensitive, I could not be otherwise than deeply 1 affected, in receiving this accolade of honor conferred by being the guest of the Lotus Club. The Chinese proverb says: "What is the use of being a mandarin of two tails if it is not known in one's native village?" I thank you for the kind expressions which the personal friendship of President Lawrence has colored so highly and so agreeably in your greeting to me. I regret my own incapacity fittingly to respond to the honor which you confer upon me. I feel myself to be in the position of the man who was asked, "Is your wife entertaining this winter?" and who answered, "Not very."

I am in the safest possible position, but the worst possible position, for originality tonight, because I am here and speaking. The only way in which any one today can secure credit for originality is by being somewhere else and letting the gentlemen of the press, out of their own fertile imaginations, originate his remarks.

I have said that the only way a man can be really original is to be silent, or to allow the gentlemen of the press to originate his remarks. We have had some signal illustrations of that in a statement purporting to come from the President of the United States, who had just been most royally entertained in St. Louis. A comforting and original genius of the press says, "The President, considering sternly for a moment, said: 'You may print from me the fact that I had nothing to eat in St. Louis '.' I ask you what genius could ever have originated that statement outside of the press. 
How could any man just coming from his entertainer's house ever have conceived such a supreme effort of originality as the statement that he had had nothing to eat! A few days ago, another genius put into the mouth of General Sir BadenPowell, the distinguished English cavalry officer who had been here looking at the movements of our cavalry, the statement that they did not amount to much anyway; that they were overfed. When a man trusts to himself and really adventures upon observations which he really makes, he is certain to be bald and uninteresting.

Your president has expressed the hope that I may enjoy the relaxation and the hilarity of this occasion. I assure you that in about ten or fifteen minutes I shall begin to enjoy it. I have been so far removed from my old friends in New York for the past four years, that it seems to me as if I were coming back from a great distance, after a long period of absence. It has not been an ordinary exile. It has so happened that the duties to which your president has referred in too complimentary terms have been so engrossing in their character, have involved dealing with questions so entirely different from those which occupied the community in which I had lived for so many years, that not merely has my body been absent, but my mind and heart and soul have been engaged in the isles of the sea. The ordinary exile who travels away from home ever finds his affection and his thoughts harking back to those he has left. For four years past not only my body but my mind has been removed to distant fields and in different occupations, so that in coming back to New York it seems to me as if $I$ had been away for an age in another world; and it seems strange to me to find you all still so young; to find that you still have the same bright and cheerful faces, no more wrinkles, no more gray hairs, no fewer hairs, no less enthusiasm, and youth, and capacity for enjoyment, than when a hundred years ago I met you. It has produced a 
curious effect upon me, this coming back; the break, the complete break, has led to my memory going back and joining itself, not to the city and the men as they were four years ago, but to the early scenes of my life here. As I come back to our streets, I think of the life of nearly forty years ago, when the first deep impressions of the lad coming fresh from the country were made. Your invitation called up most vividly to my mind a night passed in the old Lotus Club in Irving Place, when John Brougham held the center of the stage, and daylight came under the spell of that delightful master of humor and good fellowship.

$I$ recall the days when the stages in winter ran on runners on Broadway, and when the Fifth Avenue stages coming from Fulton Street had their northerly terminus at the Croton Cottage, a little road-house at Forty-first Street, where Frederick Vanderbilt's house stands now; when the Madison Avenue stages ran to the Ultima Thule of Fortysecond Street; when Pfaff's flourished on Broadway; when Wallack's Theater was the most northerly place of amusement in the city; when New York was a little provincial town of but seven hundred and fifty thousand inhabitants; and it requires an effort to bring myself down from those distant days, from the days when the first thing $I$ asked was how to get to Beecher's church, and was told to cross Fulton Ferry and follow the crowd, and, following it, found the prince, that great exponent of blood and brain in religion.

What a wonderful city it is, whose appearance and whose present activity join on to those early recollections! What a good old town it is! Men may abuse it; many hard things are said about it; it has many faults; but, after all, it closes within its limits the best of all there is, here or anywhere on earth, to those of us who believe that the hope of the world lies in the great process of liberty which is lifting up to participation, intelligent and effective participation, in govern- 
ment, the entire body of the people, leaving no class below; and those who do not believe that need hard experience for their education. Into this gateway of the western world have come since the census of 1850 , between the census of 1850 and that of 1900 , more than seventeen millions of people from across the water. Here the men of the Old World are received and taught the first lessons of citizenship, taught to stand erect in the independence of manhood, with no superior. The first results of the lesson are not lovely or agreeable, the first results of the lesson are crude and harsh and disagreeable; but it is a necessary lesson for the men who are to be self-governing and country-governing. Here the men of the Old World are taught first that liberty means not license, but ordered liberty and subordination to law. The lesson is not easily learned. The idea of freedom in its first dawning in the human mind means freedom from all limitations, and the men who grasp it first beat against the bars of order and law. But the burden is upon this city, at once, to teach the undisciplined masses of mankind who seek the freedom of the West, the double lesson of independence and liberty, but of liberty restrained and ordered by law and justice. Let the denizens of the cities and quiet fields, who have the ordering of their own lives with the lessons of free forefathers to guide them, find fault with the city of New York; but let them remember that the city of New York is doing the rough work of civilization, making over the raw material of citizenship, and standing in the post of difficulty, of hardship, and of disagreeable duty, in the preparation of mankind for that citizenship upon which alone can permanently rest the advance of mankind.

Good old New York! Absence has made me love her but the more, criticism makes me appreciate her merits but the more, and detraction makes me but the prouder of being her citizen. And when I come in for a day or two, when I 
come here and see about me the faces of the old friends with whom I have had so many good times, with whom and against whom I have fought so often, from whom I have received so many kindnesses, I want to come home. I feel like the young lady from Chicago who went to the new hotel, and wrote back to her friend that the new bath-room was so fascinating that she could hardly wait until Saturday night.

Coming from outside the city and seeing its wonderful advance, and how the municipal surgery is operating for appendicitis, taking out the bowels of the city, the kidneys, and the liver, for underground transit, for new Pennsylvania tunnels and stations; how even the New York Central has become conscious of the possession of a liver which needs excavation; how upon the surface our city is growing great and beautiful - I feel bound to say that the country, the great country with whose prosperity our city must rise or fall, which finds its flower and fruit here, keeps pace with the metropolis. I doubt if there has ever been a lustrum in which any people have made such progress as the people of the United States have made in the past five years. When we were boys at Peekskill and elsewhere, there was no higher test of capacity than a knowledge of geography; think how the people of the United States have been learning geography in the last five years; how the horizon of the American boy has been pushed back; five years ago, who knew where the Philippines were; who knew what was the road from the sea to Peking; who knew much about the West Indies? Five years ago, how much did we know about the politics of the world that centered about the Eastern Question? We have passed through an era of isolation since the days when James Monroe and John Quincy Adams were trained diplomats concerned in the affairs of civilization. We have now come into another era, in which the people of the United States have taught a lesson to every power in Christendom. The knowl- 
edge, the topics of discussion, the educational influence to be found among our people, have suddenly, like the crystals shooting out upon the surface of the water at the point of freezing, instantly spread out from our own domestic home affairs into a wide and general observation and understanding of the affairs of all mankind. The knowledge and the interest of the American people have broadened and taken in the whole world.

The possession and the use of power are strengthening the fiber and increasing the capacity of our people. The possession of money has not yet, and I have faith to believe that in the future it will not have, emasculated the American people or brought degeneracy in its wake; for the possession of money which has resulted from our wonderful prosperity is the possession of money by all the people, the length and breadth of the land. Never in this world has so much money been used for the happiness and comfort of so many people as is being used in the United States today. Never in the world have there been so many people so free from the harsh restraints of poverty, so many people able to furnish luxuries and comforts to their families, so many people able to educate their children, so many people able to perform the duties of good citizenship, and secure in the comfort and security of prosperous lives, as today. Where money is most greatly concentrated, we see but the efflorescence of wealth, in the four-in-hand parade, the red devils that shoot about the country, in the steam-yachts which carry our millionaires. But underlying it all is the greatest expenditure of money for all good and great causes that the world has ever seen. Underlying it all is that benevolence, that interest in education, that love for humanity, that willingness to labor and to spend, and to spend without limit, for the elevation of mankind, and the alleviation of suffering, in which the city of New York easily leads the world. 
I feel that in coming back to my home I shall come back to a city which has kept up in the march of progress in the forefront of a nation ever progressing; and I feel like saying tonight in this festal company: Eat, drink, and be merry, for tomorrow, and tomorrow, and still tomorrow, and for unending years, the great city which is our home and the great country that we love will not die, but live and do their work for the elevation of mankind and the progress of civilization, beyond the dreams of prophets and the hopes of philanthropists. 



\section{BENJAMIN FRANKLIN}

ADDRESS OF THE SECRETARY OF STATE ON PRESENTING TO FRANCE THE GOLD MEDAL AUTHORIZED BY CONGRESS TIIE FRANKLIN BICENTENNIAL, PHILADELPHIA APRIL 20, 1906

$\mathrm{N}$ the 27th of April, 1904, the Congress of the United States provided by statute that the Secretary of State should cause to be struck a medal to commemorate the twohundredth anniversary of the birth of Benjamin Franklin, and that one single impression on gold should be presented, under the direction of the President of the United States, to the republic of France.

Under the direction of the President I now execute this law by delivering the medal to you as the representative of the republic of France. This medal is the work of fraternal collaboration by two artists whose citizenship Americans prize highly, Louis and Augustus Saint-Gaudens. The name indicates that they may have inherited some of the fine artistic sense which makes France preëminent in the exquisite art of the medalist.

On one side of the medal you will find the wise, benign, and spirited face of Franklin. On the other side Literature, Science, and Philosophy attend, while History makes her record. The material of the medal is American gold, as was Franklin.

For itself this would be but a small dividend upon the investments which the ardent Beaumarchais made for the mythical firm of Hortalez \& Company. It would be but scanty interest on the never-ending loans yielded by the steady friendship of de Vergennes to the distressed appeals 
of Franklin. It is not appreciable even as a gift when one recalls what Lafayette, Rochambeau, de Grasse and their gallant comrades were to us, and what they did for us; when one sees in historical perspective, the great share of France in securing American independence, looming always larger from our own point of view, in comparison with what we did for ourselves.

But take it for your country as a token that with all the changing manners of the passing years, with all the vast and welcome influx of new citizens from all the countries of the earth, Americans have not forgotten their fathers and their fathers' friends.

Know by it that we have in America a sentiment for France; and a sentiment, enduring among a people, is a great and substantial fact to be reckoned with.

We feel a little closer to you of France because of what you were to Franklin. Before the resplendence and charm of your country's history - when all the world does homage to your literature, your art, your exact science, your philosophic thought - we smile with pleasure, for we feel, if we do not say: "Yes, these are old friends of ours; they were very fond of our Ben Franklin and he of them."

Made more appreciative, perhaps, by what France did for us when this old philosopher came to you, a stranger, bearing the burdens of our early poverty and distress, we feel that the enormous value of France to civilization should lead every lover of mankind, in whatever land, earnestly to desire the peace, the prosperity, the permanence, and the unchecked development, of your national life.

We, at least, cannot feel otherwise; for what you were to Franklin, we would be - we are - to you: always true and loyal friends. 
REPLY OF M. JUSSERAND, THE FRENCH AMBASSADOR

ON behalf of the French Republic, with feelings of deepest gratitude, I receive the gift offered to my country, this masterful portrait of Franklin, which a law of Congress ordered to be made and which is signed with the name, twice famous, of Saint-Gaudens.

Everything in such a present powerfully appeals to a French heart. It represents a man ever venerated and admired in my country - the scientist, the philosopher, the inventor, the leader of men, the one who gave to France her first notion of what true Americans really were. "When you were in France," the Marquis de Chastellux wrote later to Franklin, "there was no need to praise the Americans. We had only to say: Look; here is their representative."

The gift is offered in this town of Philadelphia where there exists a hall the very name of which is especially dear to every American and every French heart - the Hall of Independence - and at a gathering of a society founded "for promoting useful knowledge", which has remained true to its principle, worthy of its founder, and which numbers many whose fame is equally great on both sides of the ocean.

I receive it at the hands of one of the best servants of the state which this great country ever produced, no less admired at the head of her diplomacy now than he was lately at the head of her army, one of those rare men who prove the right man, whatever be the place. You have listened to his words, and you will agree with me when I say that I shall have two golden gifts to forward to my Government: the medal and Secretary Root's speech.

The work of art offered by America to France will be sent to Paris to be harbored in that unique museum, her Museum of Medals, where her history is, so to say, written in gold and bronze, from the fifteenth century up to now, without any 
ruler, any great event, being omitted. Some of the American past is also written there - that period so glorious when French and American history were the same history, when first rose a nation that has never since ceased to rise.

There, awaiting your gift, are preserved medals struck in France at the very time of the events, in honor of Washingtion, to commemorate the relief of Boston in 1776; a medal of John Paul Jones in honor of his naval campaign of 1779; another medal representing Washington, and one representing General Howard, to commemorate the battle of Cowpens in 1781; one to celebrate the peace of 1783 and the freedom of the thirteen states; one of Lafayette; one of Suffren, who fought so valiantly on distant seas for the same cause as Washington; one, lastly, of Franklin himself, dated 1784, bearing the famous inscription composed in honor of the great man by Turgot: Eripuit calo fulmen, sceptrumque tyrannis.

My earnest hope is that one of the next medals to be struck and added to the series will be one to commemorate the resurrection of that great town which now, at this present hour, agonizes by the shores of the Pacific. The disaster of San Francisco has awakened a feeling of deepest grief in every French heart, and a feeling of admiration, too, for the manliness displayed by the population during this awful trial. So that what will be commemorated will not be only the American nation's sorrow, but her unfailing heroism and energy.

Now your magnificent gift will be added to the collection in Paris; it will there be in its proper place. The thousands who visit that museum will be reminded by it that the ties happily formed long ago are neither broken nor distended, and they will contemplate with a veneration equal to that of their ancestors the features of one whom Mirabeau justly called one of the heroes of mankind. 


\section{JULES MARTIN CAMBON}

ADDRESS OF THE SECRETARY OF WAR AT A FAREWELL DINNER TO THE FRENCH AMBASSADOR, NOVEMBER 15, 1902

Jules Martin Cambon, born in Paris, April 5, 1849, was appointed GovernorGeneral of Algeria in 1891, and Ambassador to the United States in 1897. He represented the Spanish Government at Washington during the Spanish-American War, and signed the Spanish-American Protocol in 1898. He was appointed Ambassador to Spain in 1902, and at a farewell dinner in Washington, November 15, 190 , Mr. Root spoke as follows:

T $\mathrm{T}$ is a melancholy duty to help you in speeding this parting 1 guest. Monsieur Cambon has been an ideal ambassador. He has not merely defended, maintained, promoted the interests of his own country, but he has illustrated and made attractive and charming to the people to whom he was accredited all that was noblest and best in the people of his own country. In our modern days, where peace and not war is the normal condition of man, the victories of peace consist not in wresting territory from a hostile people, nor in carrying away from their capitals their works of art, or their wealth, but in gathering for home use all that is best in the lessons of national life and in the influences of national character.

The Teutonic race has characterized and marked the development of this new world to a degree which leads us often to forget how much we owe and how much we can derive from the great Latin race, which has given so much toward the development of civilization, and which can give so much that we lack toward our own progress, toward the perfection of national and personal life of which we dream.

Monsieur Cambon has illustrated to us all that was best in the Latin world. I have been sorry that he learned to 
speak English. I understand him better, but the grace, the beauties of his French always seem to me to raise a picture of the golden fields of grain of his country spangled with bluets and coquelicots; always seem to bring into our rougher and ruder Teutonic life something of the grace and beauty and taste with which the French people are endowing civilization.

How much we owe to it! Go back over the long history, from those early and stormy days when the Plantagenets went forth from their castles on the Loire across the seas to the conquest of England; to the War of the Hundred Years; to Louis XI with his leaden saints beating down the aristocracy of France; to Henry IV, the beau-ideal of chivalric knighthood, to whom a race of kings unequalled in history looked back with pride and reverence; to the great, the greatest of warriors, who with the power of that single nation withstood the armies of the world and gave the death-blow to hide-bound institutions which for centuries had dwarfed and bound the developing powers of civilization; to the new republic, whose footsteps we have all followed with hopes and prayers for its success and its permanency, as, during these thirty years, it was proving itself a most important, most significant stronghold of popular rights, of popular sovereignty, and of hopes for the future of the peoples of the earth, of the plain peoples of the earth in Europe. Through all the long course of the centuries, the French people have been doing, with pain, with travail, with infinite labor and sacrifice, the work of civilization and of liberty.

Through it all the sunshine of La Belle France has caused to blossom on the sour and stern soil of feudalism not merely royalty and aristocratic privilege, but chivalry and grace and beauty, and the beneficence of art - abundant blessings to mankind which soften and dignify humanity. All this Monsieur Cambon represents to us. 
It is not the least of his claims to our affection that in those dark days for Spain, when the hard decrees of fate required an end to Spain's dominion in the western hemisphere, when that people whose dignity, whose personal worth, whose abounding and estimable qualities we all recognize, were compelled to yield to overwhelming power, he was their sympathetic representative and defender. I hope that when Monsieur Cambon goes to his new mission in Madrid he will feel able with certainty to say to the gentlemen of Spain that he left behind him in America nothing but respect and esteem and admiration for them. I hope he will tell them that his advocacy of their cause, to which he brought all the subtlety of intellect, all the ability of the trained diplomatist of France, has but raised him in our esteem, and given him an added title to our respect. And it is delightful to know that this, our friend, whom we have learned to esteem so highly, is going among those whose gratitude he has earned and whose affection he must have. Our best and warmest hopes go with him for his success and his promotion of blessings and prosperity for the people of Spain and the people of France alike. Success and glory to him in his new field! Who knows what he may accomplish? Who knows what this virile, acute, and discriminating mind may do in the Iberian Peninsula? Who knows but he may lead to the union of the Gaul and the Visigoth? Who knows but from his agency may come sometime a great Latin republican empire on the continent of Europe?

Our best wishes go with you, sir. We shall follow your pathway with interest and affection. We hope great things for you; we wish great blessings for your country and the country to which you go. We bid you goodbye, we bid you God-speed, and above all we say to you, "Au Revoir, Monsieur Cambon!" 



\section{THE ASSASSINATION OF PRESIDENT CARNOT}

June 26, 1894. The New York constitutional convention having under consideration a resolution tendering to the Government of France the profound sympathy of the convention in the death of President Carnot by assassination, Mr. Root said:

T'T seems to me eminently fitting that when the represen1 tatives of seven millions of people, who depend for the preservation of their lives, their liberty, their property upon free constitutional government, are gathered in the supreme council of the state revising the foundations of social order, and in another land a blow is struck at the very heart of constitutional government, expressions of sympathy with those immediately affected, and of abhorrence for the crime, should proceed with heartiness and with sincerity from the people's representatives.

The generous aid which the republic of France vouchsafed to the infant American colonies, more than a century ago, found immediate reflex action and benefit in her own struggle for liberty. Side by side with our own American experiment in constitutional government, the French experiment has been going on for a century, under difficulties and surrounded by evils of which we have known nothing. Surmounting almost insurmountable obstacles, triumphing in the midst of successive and apparently irretrievable defeats for twenty years, the republic of France has stood erect, unshaken, consolidating and making perpetual the foundations of free constitutional government.

And now the hand of the assassin has stricken down her chief magistrate and put her people into mourning. Mr. President, the cause of freedom and of constitutional government 
is one cause the world over. The enemies of constitutional government in France are the enemies of our government, of our liberty, of our homes. With ever-changing form, the battle of good and evil, of right and wrong, of law and of license, goes on throughout the world. In the form which it assumes today, the enemies of freedom and of the law raise their horrid heads among us as well as in the cities of France. One arm for the good and the right must ever fight the same battle the world over, against wrong and against evil. But one weapon stands ready for all. But one means of success in this eternal conflict is at the hands of all, and that is the universal sympathy and support of all good men the world over, and universal detestation and abhorrence the world over for the men who, like the assassins of Carnot, of Garfield, and of Lincoln, war against all that is purest and best in mankind. In God's name, and in Liberty's name, Mr. President, let the representatives of the people of the state of New York send their sympathy to the people of the republic of France. 


\section{CANADA AND THE UNITED STATES ${ }^{1}$}

ADDRESS OF THE SECRETARY OF STATE AT A DINNER GIVEN BY THE PILGRIMS OF THE UNITED STATES IN HONOR OF THE RIGHT IIONORABLE EARL GREY, GOVERNOR-GENERAL OF CANADA, NEW YORK, MARCH 31, 1906.

$T^{T}$ is an opportunity which I highly appreciate officially 1 and it is an honor and a privilege personally to join the Pilgrims of the United States in their welcome to our distinguished guest. I am glad to welcome him for himself, because before he was Governor-General of Canada we knew him for a fitting representative of the continuous development in the old home of our race of those qualities which we most admire in our fathers, and the possession of which is the surest hope of our own continued prosperity and greatness; because he has the English great-heartedness and the English practical sense and wisdom; because he illustrates in himself how great is the influence upon a family of having the benign face of Franklin looking down from its ancestral walls. Indeed, we may believe that through that ever-present influence upon the generations, Franklin has worked out his own salvation and wrought out the character which has brought him home again to his own beloved Philadelphia.

I am glad to welcome him for his country. The policy the traditional policy - of the United States forbids alliances with other countries, but every lawyer knows, every man of affairs knows, that the signature and the seal upon a contract is of little value unless the character and purpose of the contracting parties is sincere, and that a sincere and genuine common purpose to do the thing to which a contract relates

1 See also addresses on The Builders of Canada, and The Canadian Reciprocity Agreement, pp. 157-187. 
is as efficient without the seal and the signature as it would be with them. With every country that seeks to attain the purpose that dwells in all the highest ideals of the American people, there is an alliance effective and perpetual. And wherever the English people go, wherever their institutions, their laws, their customs, are carried, there the American can breathe freely, there the American can pursue his calling without fear or hindrance; and the progress, the growth, the glory, of England is at every step a gain to every man who speaks the English tongue, who has formed his character and his customs upon English law and the genius of English institutions.

I am glad to welcome him for the great people over whom he is governor. I can do it with especial pleasure because of a genuine liking for the people of Canada - a liking for the quaint charm and grace of its French people, for the sturdy vigor, the northern virility and force, of its English-speaking people - a liking which I know is shared by the great mass of the American people, and especially by those born and bred, as I was, near the Canadian border.

I think that the American people should recognize the fact that a great change has taken place upon the other side of the border - a change which materially affects the theoretical, the assumed or supposed, relation or possibilities of relation between the United States and Canada. It was apparently, as we read the history of the negotiations which led to the treaty of peace of 1783 , rather in doubt for a time whether Canada should not be ceded and become part of the United States when our independence was recognized. In 1812 the British Governor-General of Ontario wrote, in personal letters which have since been published, that a majority of the people of his province were rather in favor of the Americans than of the English. We must recognize that a great and radical change has taken place. Canada is no 
longer the outlying northern country in which a fringe of descendants of royalists, emigrating from the colonies when they became independent of Great Britain, lived and gained a precarious subsistence from a sterile soil. It has become a great people, increasing in population and in wealth. The stirrings of a national sentiment are to be felt. In their relations to England one can see that while still loyal to their mother-country, still a loyal part of the British Empire, they are growing up, and, as the boy is to his parents when he attains manhood, they are a personality of themselves. In their relations to us they have become a sister nation. With their enormous natural wealth, with their vigor and energy, following the pathway that we have followed, protecting their industries as we have protected ours, proud of their country as we are proud of ours, they are no longer the little remnant upon our borders; they are a great and powerful sister nation. And the people of America look with no grudging or jealous eye upon this development. We bid them God-speed in their growth in greatness and in power, in their capacity to do their part for civilization, for peace and justice, for liberty and righteousness among the nations.

The newspapers have said that at this dinner an announcement would be made that all existing questions between Canada and the United States have been settled. I wish it were so. This can be said: that we are going to try to settle all existing questions; that we are trying to settle them, and that with a sincere and earnest purpose we believe we shall settle them.

The race of seals which have for so many years produced a most valuable product for the clothing of mankind are rapidly disappearing. We are going to try to stop the frightful waste which is involved in their destruction. The fish supply - the great food supply found in the fish of the Great Lakes - is being destroyed, because in those inter- 
national waters neither country can by itself enforce rules and regulations similar to those laws for game preservation which are maintained within our own jurisdiction and the Canadian jurisdiction. We are going to try to agree upon regulations which shall be binding on both sides of the dividing line. The northeastern fisheries questions have been under discussion ever since they were settled finally in the Treaty of Utrecht of 1713. We are going to try once more to settle them. ${ }^{1}$ There are boundaries remaining to be marked. There are many other questions that ought to be disposed of. And now, while there is no controversy about them, we are going to try to get rid of them. The trouble with such questions is, that people are too apt to treat them like the man who did not mend his roof when it rained because he would get wet and did not mend it when it did not rain because it did not leak. The Alaska boundary question could have been settled without difficulty at any time for many years; there was no controversy about it, and it failed of settlement because our Congress was unwilling to make an appropriation to survey the boundary; and through that fatuous refusal to dispose of the question when there was no controversy, there came a most critical situation, the settlement of which was exceedingly difficult. It has left, I fear, much hard feeling, which will disappear, I hope, in time and in a very short time.

But we are at peace. It is just three hundred years since Henry IV, the greatest of French monarchs, conceived his great design to set a bound to ambition in Europe and to secure the disarmament of European powers; and formed a fast and firm alliance with the great Elizabeth of England to secure that end. Three hundred years have passed, and still on the frontiers of Europe millions of armed men jealously

1 See the North Allantic Fisherics Arbitration-Oral Argument of Elihu Root. Harvard University Press, 1917. 
watch for incursions of possible enemies. But with us, eighty-nine years ago, by a simple exchange of notes, the British and American Governments agreed upon disarmament on the great international waters between Canada and the United States; and today millions of people, thriving cities, wealth beyond computation, are free from wars, from alarms of wars, - as safe without a cannon or a fort as if they were in the center of this great land. Long may this condition continue! Never may it cease! It will not cease.

If ever and anywhere two peoples should live together in peace, the peoples of Canada and of the United States should illustrate the effect of generations practicing justice, obeying law, abhorring war. But, my friends, this condition will not continue except by the doing of the things which are necessary to peace. Not governments, today, but peoples, preserve peace. Governments but register the decrees of democracies, and the peoples of these countries whose borders march with each other have in their own hands the preservation of peace and have resting upon themselves the duty of doing the things necessary to that preservation.

With nations, as with individuals, the laws which govern the peace of a community obtain. Nations have souls and duties, as well as rights. The people who are grasping and arrogant meet the same fate as the man in his community who is grasping and arrogant. The people who insist upon having everything that the most extreme view of their rights or their desires may call for, have themselves to blame if strife arises. A regard for the rights - for the just rights for the feelings, for the sympathies - aye, for the prejudices - of the sister people, not merely with the President at Washington and the Governor-General and Premier in Ottawa and the Foreign Office in London, but among the people of the United States and of Canada, is necessary to the maintenance of this happy condition. 
In dealing with all the questions that exist today, and with all the questions which will continually arise in the years and the centuries to come, our people have resting upon them the duty to be just, to be considerate, to be not grasping and arrogant but to deal with our sister people as a just and kindly man would deal with his neighbor at home. If the people of the United States will do that, and the people of Canada will do that, then never shall this great border bristle again with guns, never shall this blessed condition under which we live in the safety of one people be disturbed, and never will all our proud boasts of love for liberty and justice and peace be set at naught. 


\section{THE BUILDERS OF CANADA}

\section{ADDRESS OF THE SECRETARY OF STATE AT A BANQUET OF THE CANADIAN CLUB OF OTTAWA, CANADA \\ JANUARY 29,1907}

THANK you for your most cordial and friendly greeting. I beg you to believe that I am deeply sensible of the honor conferred upon me by the presence at this luncheon table of the Governor-General and the Premier of Canada. Another kindly greeting has been received by me, since I took my seat at the table, from a gentleman who, for reasons which you will readily appreciate, was unable to obtain a seat in the room. I will take the liberty of reading it to you. It is a telegraphic dispatch dated Jamaica, January 20, received in Washington yesterday and repeated to me:

Honorable Elihu Root,

Secretary of State.

Jamaica profoundly grateful to your excellency for expression of sympathy and for the very practical aid so kindly given by Admiral Davis and the entire particular service squadron of the United States Government.

(Signed)

Governor Swettenham.

I do not feel at all a stranger here, partly perhaps because in your climate blood has to be thicker than water; partly because in your atmosphere every one born and bred under the common law of England and under the principles of justice and liberty that the English-speaking race has carried the world over, wherever it has gone, must breathe freely. It is a full forty years since I paid my first visit to Canada. At brief intervals during all that period $I$ have been returning, sometimes to one part of the Dominion and sometimes to another, but always keeping in touch with the course 
of your development and with the trend of your opinion and spirit. During that time what wonderful things we have seen! We have seen feeble, ill-compacted, separate, dependent colonies growing into a great and vigorous nation. We have seen the two branches of the Canadian people, the English-speaking and the French-speaking, putting behind them old resentments and steadily approaching each other in tightening bonds of sympathy and national fellowship a happy augury for the continuance of that entente cordiale which between the two great nations on the other side of the Atlantic is making for the peace of the world. We have seen not merely growth in population and in wealth, but we have seen here great examples of constructive power, examples of a great race of builders who have made and are making and are to make the western world unexampled in the history of mankind. The spirit of the Norse sea-kings, the spirit of the great navigators, of Columbus, of Vasco da Gama, and of Drake and Frobisher, the spirit of the Spanish conquistadores, the spirit of men of power and might who have been the great influences in the world, has found its development in this western hemisphere in the great builders, and within our lives we have seen here some of the greatest of the great building men of constructive power and energy. We have seen and are seeing now the growth of that historic sense, the growth among the people of that appreciation of the great examples of their own best nature which is so essential to the making of a nation; and as you are drawing away, through the course of successive generations, from the past, the great figures of the makers of Canada loom up more and still more lofty. The courage, the fortitude, the heroism, the selfdevotion of the men of Canada's early time stand out in historic eminence from which well may flow the deep and unending stream of a great national patriotism. Above all, we see a people trained and training themselves in the art of 
self-government, in the discussion and consideration of all public questions, not only in the high seats of government, but in the farmhouse and the shop; in that discussion which lies at the base of modern civilization, that discussion which among the plain people, furnishing the basis for political and social systems, differentiates our later-day civilization from all the civilizations of the past, and must give to it a perpetuity that no civilization of the past has had.

Lord Grey has very kindly furnished me, in the last few days, with the debate which has been going on in your House of Commons on the subject of the fisheries modus vivendi. I have been much impressed by the thoughtful, temperate, and statesmanlike quality which has been conspicuous in that debate. I am sure, and indeed no one who reads the debate can doubt, that whatever conclusion your Parliament reaches will be a conclusion dictated by sincere and intelligent and right-minded determination to fulfill the full duty of your representatives to the people whose rights they are bound to maintain and protect. Whatever the conclusion may be, however much any may differ from it, all men will be bound to respect it. The existence of this club, the existence of similar clubs in the great cities throughout your country, is an augury, a good omen, for the future of Canada. That intelligent discussion and consideration of public questions which enable the men who are not in office to perform their duty as self-governors is a solid foundation for a nation that shall endure.

For all these I profess, with sincerity and with feeling, my admiration and my sympathy; and I speak the sentiment of millions of my own countrymen in saying that we look upon the great material and spiritual progress of Canada with no feelings of jealousy, but with admiration, with hope, and with gratification. I count myself happy to be one of those who cannot be indifferent to the glories and achievements of 
the race from which they spring. And with my pride in my own land, with the pride that it is a part of my inheritance to take in England, is added the pride that I feel in this great, hardy, vigorous, self-governing people of Canada, who love justice and liberty.

There have been in the past, and in the nature of things there will be continually arising in the future, matters of difference between the two nations. How could it be otherwise, with adjacent seacoasts and more than three thousand miles of boundary upon which we march? How could it be otherwise in the nature of the races at work ? Savage nature is never subdued to the uses of man, empires are never builded, save by men of vigor and power, men intense in the pursuit of their objects, strong in their confidence in their own opinions, engrossed in the pursuit of their ends, sometimes even to the exclusion of thoughtfulness for the interests and feelings of others. But let us school ourselves and teach our children, to believe that whatever differences arise, different understandings as to the facts on different sides of the boundary line, the effect of different environment, different points of view, rather than intentional or conscious unfairness, are at the base of the differences. After all, as we look back over the records of history; after all, in the far view of the future, all the differences of each day and generation are but trifling compared with the great fact that these two nations are pursuing the same ideals of liberty and justice, are doing their work side by side for the peace and righteousness of the world in peace with each other.

The differences of each generation loom large, held close to the eye; but, after all, the fact that for ninety years, under a simple exchange of notes limiting the armament of the two countries, in terms which have become an antiquated example of naval literature, to single 100-ton boats with single 18-pound cannon - after all, the fact that for ninety years 
under that simple exchange of notes we have been living on either side of this three thousand miles of boundary in peace, with no more thought or fear of hostilities than if we were the same people, is a great fact in history and a great fact of potential import for the future. We celebrate great victories. Anniversaries of great single events call together crowds and are the subject of inspiring addresses. Within a few years eight years from now - we shall be able to celebrate the centennial anniversary of a hundred years of peaceful fellowship - a hundred years during which no part of the fruits of industry and enterprise has been diverted from the building up of peaceful and happy homes, from the exercise and promotion of religion, from the education of children and the succor of the distressed and unfortunate, to be expended in warlike attack by one people upon the other.

In the meantime, our people are passing in great numbers across this invisible boundary, Canadians in the east and Americans in the west; and in thousands of homes they and their children are looking back from American hillsides to a Canadian, and from Canadian farms to an American, fatherland. May that backward look of loving memory never be turned to the hard gaze of hostility, of fear, or of revenge! I ask you, my friends, to join me in a sentiment: To the Canadian settlers in New England and the American settlers in the Canadian West - may they ever, with loyal memory, do honor to the lands of their birth! may they ever, with loyal citizenship, do God's service to the countries of their adoption! 



\section{THE CANADIAN RECIPROCITY AGREEMENT}

After the passage of the Payne-Aldrich tariff law in 1910, President Taft secured the consent of the British Government to enter into direct negotiation with the Canadian Government with a view to reciprocal tariff adjustments. Commissioners were appointed by the two governments, who met in Washington and in Ottawa to negotiate a treaty of commercial reciprocity. In January, 1911, the commissioners concluded an agreement which was not to be embodied in a formal treaty, but was to come into effect by concurrent legislation at Ottawa and Washington. Schedules of the agreement specified $(a)$ a number of articles the growth, product, or manufacture of the United States to be admitted into Canada free of duty when imported from the United States, and, reciprocally, a number of articles the growth, product, or manufacture of Canada to be admitted into the United States free of duty when imported from Canada; (b) a number of articles on which a common rate of duty would be imposed; and ( $c$ and $d$ ) a few articles subject to special rates. The bill to put this agreement into effect passed the House of Representatives April 21, 1911, and passed the Senate, July 22, 1911. The ensuing campaign in the Dominion of Canada resulted in the defeat of Sir Wilfred Laurier's Government, which had warmly supported the agreement, and the Conservative Government which succeeded abandoned the project. The courts have decided that the United States reciprocity act was repealed by implication by the passage of the Underwood Tariff Act. While the bill to promote reciprocal trade relations with the Dominion of Canada was under consideration in the Senate, Mr. Root, on June 21, 1911, made the following elaborate argument in favor of its passage:

$N$ the twenty-sixth of January of this year the President
sent to Congress a message in writing, accompanied by papers entitled "Correspondence embodying an agreement between the Department of State and the Canadian Government in regard to reciprocal tariff legislation "; also statistical data to show the effect of the above agreement upon the commerce and revenues of the United States and the Dominion of Canada.

The President in his message recommended legislation by Congress in accordance with the provisions of the agreement embodied in the correspondence thus transmitted by him. 
The bill which is now before the Senate, House Bill No. 4412, is entitled "An act to promote reciprocal trade relations with the Dominion of Canada, and for other purposes"; and throughout the greater part of the bill, that is to say, down to the end of section 1, on the twenty-third page, the bill does follow the agreement which is described as between the Department of State and the Canadian Government in regard to reciprocal tariff legislation.

The action of the President in bringing before Congress this subject affecting the foreign relations of the United States in this manner has been the subject of criticism to some extent in the public press and to some extent upon the floor of either House of Congress. I should not refer to this criticism were it not that it has received the dignity and authority derived from the advocacy of the distinguished senior Senator from Minnesota [Mr. Nelson], whose solid and sterling qualities we all recognize and admire.

I wish to submit to the Senate, sir, that the President has followed a course in bringing this subject before Congress which was entirely within his power, which was in accordance with precedents, and which was strictly in accordance with official propriety.

The agreement between the Department of State and the Canadian Government has been spoken of as a treaty. It is in no sense a treaty. It is one of those informal, temporary, and preliminary arrangements between the executive branches of two Governments which are exceedingly common and which are necessary for the effective conduct of negotiations regarding international affairs.

For example, in the year 1899, when the dispute between this country and Great Britain regarding the Alaskan boundary was at its height, the State Department entered into an agreement with the Government of Great Britain fixing the line on either side of which the jurisdiction of the respective 
countries should be recognized until such time should elapse as to make it possible for a final and definitive settlement of the controversy to be reached. That was not a treaty. It destroyed no property or jurisdiction and it created none, but it was a necessary arrangement in order that while the two Governments, through their constitutional treatymaking powers, were settling the question, there might not be controversy and bloodshed. That controversy was ultimately settled by a treaty between the two countries for a tribunal to hear and determine the question, and that question has been heard and determined and has passed into history.

In 1906, when the controversy as to the rights of our fishermen upon the treaty coast of Newfoundland was rife, the Department of State and the Government of Great Britain entered into an agreement as to what the colonial authorities of Newfoundland should be permitted to do and should not do, as to what American fishermen should do and should not do. It was not a treaty, but it was an agreement between these executive branches of the two Governments temporary and preliminary to a final settlement, so that there might not bestrife and actual conflict pending the settlement, and it held a condition of peace until by a treaty between the two countries and an arbitration the question was finally disposed of.

Mr. President, it makes no difference whatever whether the question is to be settled by treaty or by legislation, so long as there is a question and it is deemed desirable by the executive authority charged with the conduct of negotiations, that there shall be a preliminary arrangement until a final decision shall be reached upon the question by the duly constituted and empowered authorities of the two countries; it makes no difference whether those authorities who are to settle the question are the Senate with the President or the Senate with the House of Representatives and the President, 
whether the settlement is to come by the making of a treaty or to come by the making of concurrent laws by the two countries.

This agreement, Mr. President, is of a still lower and milder form than the agreements to which $I$ have referred. It does not in its terms, as did those agreements, bind the Governments of the countries at all. It does not bind the United States nor Great Britain nor Canada. It does not bind the Government of the United States nor that of Great Britain nor that of Canada. It is merely an agreement relating to the course of conduct which will be followed by the President and the State Department on the one hand and the administration in Canada on the other, a thing which is done every day, without which the business of negotiation between different countries and the diplomatic intercourse between different countries cannot be pursued. If a president or a secretary of state or a minister of foreign affairs cannot say what he will do, cannot bind himself regarding his conduct, if he cannot say, "I will answer your letter tomorrow"; if he cannot say "I will give you an audience next week Thursday"; if he cannot say, "No action will be taken upon this until such time as you shall have had an opportunity for an interview and hearing", why, then, business cannot go on. This agreement, I repeat, is but the most ordinary example of a class of assurance given by the diplomatic officers of one country to the diplomatic officers of another regarding their own conduct.

Now, the President has in a great measure executed the agreement that he made, by the recommendation which he has sent to Congress; and when the matter comes before Congress it has no element of a treaty. There is no treaty. There is a recommendation from the President with the information that Canada, in case we comply with his recommendation, is ready to enact similar legislation on her part. 
What is now before us is a bill which stands upon the same basis as all other bills to be considered and to be enacted by the legislative power of our Government.

This bill might have been the product of a treaty. The President, with the advice and consent of the Senate, might have made a treaty, under which there would have been an agreement to submit this legislation to Congress. He did not do so. There would have been no object in his doing so, because it would have resulted merely in making the same submission to the legislative power which is now made. He has taken the simple, direct, natural, and proper course in making this recommendation to Congress in accordance with his constitutional authority, and acting in good faith, pursuant to the agreement which he made regarding his own conduct and in accordance with his right, with precedent, and with propriety.

Mr. President, the agreement which was submitted to Congress by the President meets with my approval. There were many reasons why it naturally appealed to me and why my first impulses were to favor it, because by long years of labor in the direction of the settlement of differences and the promotion of kindly and friendly feelings between this country and Canada, I have acquired that habit of mind. Be that as it may, I was at the beginning, and always have been and am now, in favor of giving effect to the President's recommendation for the reciprocal arrangements with Canada.

But, Mr. President, I have not been permitted to maintain that view in any complacent or untroubled mood. It has been impossible for me so to steel myself against the opposition of the farmers of northern New York and of the papermaking communities of northern New York, in which tens of thousands of people are dependent upon that industry, that I could hold my course in support of this reciprocity agreement without disturbance and solicitude. 
The farmers of northern New York, more in number than the entire inhabitants of many of the states represented in this chamber, are in a great measure opposed to this agreement, and they have by thousands of communications to me made their opposition known. They fear that it will result in the reduction of the price of their products and in the depreciation of the value of their lands, and in making harder the severe conditions of their lives. I cannot but be affected by their representations. They are the people among whom I was born and grew to manhood, among whom I live, and I would not have them feel that $I$ am unmindful of their interests; nor, Mr. President, can I be indifferent to the speeches which $I$ have heard here in this chamber - speeches made by old and tried associates, upon whose sincerity $\mathrm{I}$ would stake everything I possess, for whose judgment I have respect, and with whose deep and evident feelings $I$ have sympathy. But, Mr. President, nevertheless, I do still believe that the enactment of this reciprocal agreement with Canada is for the best and the permanent interest of our country, and I must be for it.

I think, sir, that my friends, the farmers in New York and the farmers all along the northern border, are unduly apprehensive. I think that they have greatly exaggerated in their own minds the injury which will come to them from the enactment of this measure. It is but natural that they should. All experience in the enactment of tariff laws indicates that those whose business is to be affected greatly exaggerate the injury which they apprehend from any legislation that at all reduces the measure of protection which they have had; and if it be true, as would appear from the report of the hearings before the Committee on Finance, that an organized effort has been made, with agents or attorneys employed to circulate among the farmers of the country statements of the injury that will be done to them, in order to arouse them to 
opposition to this bill, it follows necessarily that the arguments would lose nothing in the telling, and that to every farmer would come a tale of apprehension and of anticipated injury, painted in the most vivid colors. So that it is but natural that this feeling should exist; but I think it is greatly exaggerated.

The apprehension of injury, which is natural to any class of producers as to whom there is a proposal to reduce the tariff, is very readily to be answered by the fact that the two countries are under substantially the same conditions. There may be little differences in labor cost here and there, but, in general, by and large, the labor conditions of Canada and the labor conditions of the United States are the same. It is not a question of competing with the familiar adversary, the pauper labor of Europe. The two countries are similar in their social conditions, in their laws, in their manner of doing business, of thinking and of acting, in their individual independence, and in their power to maintain their wage scale; and the proposal to take down the tariff wall between Canada and the United States, in so far as it is taken down by this reciprocity agreement, is much more like the taking down of a tariff wall between two states than it is the taking down of a tariff wall between the United States and the countries of Europe; and, for reasons which I shall give presently, I think that any ill effect that may be produced upon any of our farmers will be more than counterbalanced by the advantages which they will derive in common with the whole American people from the enactment of the bill.

Mr. President, I could not be indifferent to what has been said upon this floor as to the effect of this measure upon the general policy of protection. We have been told here that if this bill be passed it will drive a wedge into the protective system that now obtains, will rend it asunder, will split it into pieces, and will destroy it. We have been told that if this 
bill passes, the farmers of the Northwest will see to it that the manufacturers of New York and Massachusetts and Pennsylvania suffer in their turn. These are serious propositions, Mr. President, for one who believes, as I believe, that the policy of protection has played a great part in the building up of the prosperity and the happiness of our country, and who believes, as I believe, that to continue the policy of moderate protection, reasonable protection, based upon ascertained facts, is of high importance to the future prosperity and happiness of our country.

A serious picture is presented to us by these declarations coming from men whose sincerity we respect; but, Mr. President, it appears to me that throughout this whole discussion, and very much of late in other discussions in this chamber which have touched upon tariff questions, there has been always a suppressed premise - an assumption never stated but always present - that what we make tariff laws for is to benefit the manufacturer or the miner or the farmer or whoever may be engaged in the industry that we protect.

I say there is running through the discussion of this subject the assumption that we make tariff laws for the benefit of the people who are engaged in the industries. That I deny. We make, or we ought to make, no law for the benefit of any man or any group of men. We care no more, Mr. President, neither you nor I, nor the Senators about me, for any manufacturer, great or small, of any article, be it steel or wool or cotton or what-not, or for any miner, whatever he may be taking from the earth, or for any farmer, or for any granger upon this earth than we care for the men who are using their products. And we do not protect them for their benefit.

We pass all laws putting protection on the products of industry for the benefit of the whole American people, and if we cannot sustain the imposition of a duty upon that ground, then it ought not to be imposed. If we do legislate for the 
benefit of the people engaged in any particular industry, then we are perverting our powers; we are false to our duty.

Mr. President, it is because for the moment, for the time being, the people of the United States have come - many of them, I hope not all, but many of them - to believe that we have forgotten this primary and fundamental rule of tariff legislation, because they have been led - misled, I believe into the conviction that we have been legislating for particular men or particular groups of men instead of legislating for the interests of the whole country, that the people overturned the majority in the House of Representatives in the last election and very nearly, and in a certain sense altogether, changed the political complexion of the Senate.

Mr. President, when my friends, who declare that this legislation, if it be enacted, will be the death blow of protection, and their constituents, in the cool afterthought, consider, as they will consider, the interests of the whole people, they will forget their revenges, and they will vote in accordance with their principles, under the guidance of their love of their country, for protection or against protection, and if for protection for such measure of protection as they believe will help not the manufacturers of New York or Massachusetts, but the whole people of our country.

Mr. McCumber. Does the Senator believe that while the public may forget their revenges in forgetting they will lose their sense of justice and equal justice to all the people?

Mr. Rоoт. I do not. I count on their keeping it, and I know they will keep it and will act under their sense of justice, a sense of justice to the whole people of the United States. Mr. President, let me say this: No economic system, be it for protection, be it for a tariff for revenue, be it for free raw materials and high duties upon finished products - no economic system can stand upon any other basis than that which I am pressing as a necessary basis on which we 
must act regarding this legislation and on which my friends who are opposing this legislation ultimately will act.

I believe a reasonable policy of protection is beneficial to our country; I believe it tends to make it more prosperous, more happy, more useful in the world, and that it provides a better home for our people, with greater opportunities for every one of us. But, Mr. President, I know that that view of protection cannot prevail if protection is to be rested by its advocates upon a system of bargain and trade. I believe in protection, but I wish to buy no man's vote for it. If the majority of the people of the United States come to the conclusion that it is better for the country to abandon protection and establish a revenue tariff or free trade - under any name whatever - then let them do it, and I for one will put out no hand to stay them by bargaining and trading the respective private interests of different parts of our country. If they are wrong in abandoning protection, then they will find it out and come back.' If they are right in abandoning protection, then we will confess our error, according to the outcome.

And, Mr. President, if we have so sinned against the duty of keeping always an eye single to the interests of all our country as to leave the system of protection to be tried not upon its merits, but upon its abuses, then we must endure the tribulation that is to come upon us before the hard lesson is learned that there is a sound and impregnable basis for a protective tariff law which concerns no private or individual interest, but concerns the power and prosperity and happiness of our whole country.

I wish to say one word further with special reference to the effect of this law upon the farmer. If I were at home I would say it in private conversation to my farmer friends about me in the country, and that is this: The taking off of the duty on farm products between this country and Canada, 
while it will in a technical sense, a strict sense, be accomplished by the passage of this bill, nevertheless was inevitable; and if it did not come in this bill it would come in its own way by ordinary tariff legislation.

No one can mistake, no one ought so to blind himself as to mistake, the changed feeling of the people of this country regarding the tariff as exhibited by the election of last fall, and not only by the election of last fall, but exhibited in ten thousand expressions all over the country and exhibited in the highest degree by the possibility of this reciprocal arrangement.

No one may suppose that this arrangement could be made by the President, carried through the House, certain of passage here in the Senate, if there were not a great public opinion behind it. What we say here is of little consequence. Our arguments do not advance or retard it. It is moving along with a public opinion behind it.

Mr. President, there is no one here who believes that there is the least possibility that the people of the United States, until another revolution of sentiment has come, will permit the cost of their living to be increased by the imposition of a duty on ordinary food-stuffs. . . .

Mr. President, I have stated my view regarding the inevitable result of the process which is now going on upon the system of food duties. I never have thought that the duties which were imposed upon farm products were of any real general benefit to the farmer. They have been quite indifferent, affecting only several localities here and there, so long as our production ran far ahead of our consumption. But, with the increase of our cities as compared with our farming population and the using up of our waste lands and the fencing in of old cattle ranges and the reduction of the productive power of our land, we have about come to the point where the continuance of those duties, instead of being a matter of 
indifference to the people of the country, would result in putting up the cost of food.

I am not arguing the question. I am simply stating a reason why the farmers should not consider that this reciprocity arrangement is doing them any particular harm, because it is something that is sure to come to them anyway. -

Mr. McCumber. Does the Senator believe it would be a bad condition to arrive at when consumption and production were about equalized with each other? Does he not believe, on the contrary, that we would get nearer an element of justice upon the price of the article sold and the price that is paid for it, upon the energy expended in producing the article and the energy expended in securing the money to purchase it? Does the Senator really feel that there would be an injustice to the consumers if the farmers produced just about what the consumers needed; and will not the Senator agree with me that today it takes a great deal more expended energy upon the farm to produce a bushel of wheat than it takes in the factory or elsewhere to buy the flour that is in that wheat? Is not that a correct proposition?

Mr. Rоoт. There are several propositions involved in what the Senator has said. As to his first question, about the result of production and consumption. I think it is desirable to have a production for export. So long as we have any money to spend abroad we will spend it, notwithstanding the vigilance of the customs authorities. We will expend some of it, at all events, and I think it is a good thing to keep the balance of trade in our favor. So I like to see a surplus of production.

As to the other question, I do not think that I quite understand it.

Mr. McCumber. My proposition, I will say to the Senator, was simply that it requires far more labor on the farm to 
produce the wheat that goes into a loaf of bread than it requires in the city to earn the value of that loaf of bread.

Mr. Root. I am inclined to think that is true.

Mr. McCumber. Then should not the law, in so far as the law affects the value of the property, tend rather to equalize this condition than to cheapen the product of the farm for the benefit of the person in the city who purchases it?

Mr. Root. No; I do not think it is our business to equalize that condition by law. I think that is a matter of trade, which should be equalized by the natural forces which govern trade.

Mr. McCumber. Have we not been equalizing those conditions by our protective system, and is not the whole argument of protection based upon the idea that we do equalize our conditions as against the conditions of the foreign markets?

Mr. Root. That is an entirely different question, Mr. President. It is not that we equalize trade conditions as between ourselves. We have never undertaken to do that by our tariff legislation, and I do not think we ever shall undertake to do it.

Mr. Reed. Do I understand the Senator to say he concedes the point that it takes more labor to produce a loaf of bread than to earn the money to buy it in a city?

Mr. Rоoт. I said I was inclined to think that was true.

Mr. REeD. I differ very strongly from the Senator on that point.

Mr. Root. I may be wrong. I do not make myself responsible for the statement, but I am inclined to think it is true that it takes less labor to earn the money to buy a loaf of bread in the city than it does to raise the loaf of bread in the country - that is, that less money goes to the producer. Of course, there may be, and frequently is, any amount of 
putting up of price through successive middlemen, who destroy the relation between the producer's reward for his labor and the consumer's cost for the article which he consumes. The great problem of distribution, of bringing the products from the original producer to the consumer is a subject which very much needs attention, but it is no part of a tariff law or a reciprocity agreement with Canada.

Mr. Martine. I want to ask the honorable Senator from New York if it is not his admission here, from what he has just stated, that the farmer has received no benefit from the tariff; that he, in other words, has been hoodwinked with the idea that the protective tariff was protecting him? Is not that your statement, sir?

Mr. Rоoт. Mr. President, the distinguished Senator from New Jersey puts a question to me and then puts a gloss on his question.

Mr. Martine. I want it glossed so that the Senator will not get away from it.

Mr. Root. Yes; but the Senator from New Jersey must not hoodwink my answer.

Mr. Martine. I have no disposition to do that.

Mr. Root. I must be permitted to answer the question of the Senator, because a question put by him is always entitled to respectful consideration. I think that here and there, at certain localities along the border, farmers have been benefited by protection on their food products. I do not think that as a class in general up to this time or until perhaps within a very short period, the protection upon food products has been of any real advantage to the farmer. I do not think that the Senator from New Jersey is justified in inferring from that that the farmers have been hoodwinked. I think that the farmers have, upon their own good judgment, believed that it was beneficial to them to have this duty, probably more because they were looking forward to the time when it 
would be useful for them than that they thought it had already been useful for them as a class.

Mr. Martine. The farmers have been looking for fortyodd years for the magnificent dream and the rainbow that was to come. But each year the struggle for the bread-andbutter winner and toiler has grown harder and harder and more bitter, while they have seen their farms sold out under foreclosure and the manufacturers growing wealthy beyond the dreams of avarice. Hence the farmers of this land have held up their hands to God and said, "Pray, how long!" and the last election decreed that it would be short. I can say to the distinguished Senator from my neighboring state, in which I was born, that your day of promise is too far off with your Republican talk of protection, and we want no more of it.

Mr. Root. Mr. President, I am glad the Senator from New Jersey has completed his question. He really ought not, under permission to put a question, make my poor, dull remarks the matrix in which shall shine the bright jewels of his eloquence.

Mr. President, let me now pass to what seems to me to be the general and controlling consideration affecting this reciprocity agreement. I have always thought that the surrender of the right to impose tariff duties against each other by the original thirteen states was the most valuable act forming a part of the constitution of our government. I have always thought that that played a greater part in the prosperity and progress and friendly intercourse of our states than any other thing that they did or refrained from doing in forming the government of the United States.

Mr. President, it seems to me that the existence of a political line between Canada and the United States does not militate at all against the proposition that in like manner the taking down of the tariff wall between these two kindred 
states, these two communities of people speaking the same language, living under the same system of law, with the same wage scale in general, the same habits of thought and action, the same methods of conducting business, as similar in all respects as the people of the thirteen states were to each other, will bring the same benefits to the people of both countries.

Mr. ClaArK. I'suppose the Senator has considered, perhaps from that point of view, the difference that exists between Canada and the United States with relation to the imports from other countries which does not exist between the several states of the Union. I should like to have the Senator's view upon that point.

Mr. Root. Mr. President, I do not think that that at all affects the general proposition which I am making. I can see that the fact that Canada has a different tariff from the United States, as against the people of all outside countries, may prove an embarrassment in detail; but as to the general proposition that the utmost freedom - the greatest possible freedom - of trade between Canada and the United States will bring to both countries the same great blessings that it has brought to the different states of our Union, I think this matter of detail plays no part whatever. I do not think, Mr. President, that the people of New York have been injured because there was full and free trade between them and the people of Pennsylvania. I do not think the people of New York and Pennsylvania and New Jersey and Massachusetts have been injured in the long run, by and large, by the opening up of the great wheat and corn fields of the western prairies and the valleys of the Mississippi and Missouri, and the plains, and the Pacific. I think that while they may have been required to change the character of their crops here and there, while they have been hindered here in a particular respect or there in a particular respect, the fact that they, 
with their farms and their farmhouses, their fields and their crops, were part of the great activity, having available to them the vast and effective machinery of a great and powerful and prosperous country, has overborne and counterbalanced a hundred times over any harm that has come to them from the freest competition on the part of these other communities.

Mr. Dixon. I have agreed with many things the Senator has said. I would not object strongly to vote for absolute free trade between Canada and the United States. But the Senator omits the basic criticism of the Republican Senators here who are in opposition to this treaty; that is, the rank injustice of making free trade in agricultural products alone and still leaving tariff duties and tariff walls between the two countries on manufactured articles. That is what we complain of, and that is what I should like the Senator from New York to elucidate with his wonderful ability.

$\mathrm{Mr}$. Rоoт. It is quite plain, and it is a fact - if it were not plain upon the papers, I think that we all of us know -that Canada was unable to go further than she did go in her reciprocal agreement regarding manufactured products, and we are left, therefore, in this position, that while our reciprocal legislation, that is, our legislation reducing certain duties in consideration of Canada's legislation reducing certain duties, goes only to the mark to which Canada could be brought in the agreement - the mark to which she found herself able to go in the agreement - nevertheless we are at liberty quite independently of that reciprocal agreement to go on and reduce or take off any other duties that we see fit.

Mr. President, I do not doubt that the American people will stand for doing whatever is just, and I do not want to prevent their doing whatever is just. If it is just and for the best interests of the whole country that the duties on the manufactured products of New York should be cut down, let 
them be cut down. That is no reason why we should not pass this reciprocity agreement. That is my view about it.

Mr. President, I wish to hasten to a conclusion. I have said that I think the same great benefits will come from freer trade with Canada that came to our states from tearing down the tariff walls between each other.

Mr. Williams. I do not want to interrupt the argument of the Senator from New York; I am very much interested in it; but I should like to ask him a question. Does he not think that this agreement, even though it does not go to the extent he has indicated, may be a first step toward yet freer trade relations with Canada in manufactures as well as in natural products?

Mr. Rоoт. I hope it will. I share in the hope that was expressed by the House in the concluding clause that they put into the bill. In all such matters we have to go step by step, and every friendly arrangement which is made between two countries which works satisfactorily to mutual benefit makes some further friendly arrangement more possible and easy.

Now, let me return to the proposition. The fact that there is a deeper and broader political line between Canada and the several states than there is between the states, to my mind makes no difference whatever in the practical certainty that the same great benefits will come from breaking down the trade barricr. The political line is of no consequence in such matters. It is the character of the people, their law, their language, their business habits, their conditions of life, that make intercourse upon equal terms natural and easy, which are of importance.

Mr. President, I have regretted to hear remarks made from time to time, sometimes I have thought through inadvertence, and sometimes I have feared with a hope of beating this reciprocity agreement on the other side of the line, about the annexation of Canada. Let us dismiss from our minds, if it has found any resting-place in the mind of any of us, any such 
idea. There may have been a time, generations ago, when it was possible that such an idea should receive consideration. That time has long since passed. Canada, with her wonderful progress of the last twenty years, has become a nation, and she is instinct with the spirit of nationalism. Never in the most assertive and vigorous times of our young republic was there a greater sense of patriotic nationality than exists in Canada today. The political line will continue between Canada and the United States. Her loyalty, her love for her mother-country, will continue; her separate nationality will continue; but across the line of political division will pass and repass the messages of trade and intimate business relation and intimate personal relation, which will create for both peoples the blessings that our states have received from each other in our happy Union.

Mr. President, there is another consideration that I cannot leave out of mind. When I consider the mighty power to which that northern neighbor is sure to grow; when I consider the three thousand miles of boundary, when I look across the Atlantic and see the nations of Europe each an intrenched camp, each scanning the other across battlements and ranks of steel, with suspicion and distrust; and when I think of the possibility that we here may be robbed of the happy security in which we have so long lived by the growth of an unfriendly neighbor to our north, powerful and vigorous as we have been, I confess, sir, that all small calculation or detailed advantage or disadvantage sinks into insignificance compared with the overmastering duty of inaugurating and maintaining a national policy toward this infant of mighty strength - a policy which shall make two peoples bound together in the ties of friendship, rendering it impossible that we should duplicate the conditions of Europe.

Mr. President, one of the Senators here the other day recounted the number of times that Canada had knocked at our 
doors for reciprocity and had been turned away. Ah, yes, that is true; it is true that for many years we have conducted our Government under a policy that has wounded the people of Canada, has wounded their self-respect, wounded their feelings, made them indignant and created unfriendly feelings toward the Government of the United States. It has been a stupid policy, and it is time for us to depart from it. Never again should the friendly approaches of this most friendly people be met with indifference. Now is the time, if we love our whole country and are willing to look far into the future, to shape our policy so that our strength shall help the growth of Canada and Canada's strength shall help our growth; that the power of each shall contribute to the power of the other; and that the enduring friendship of each for the other shall make the great English-speaking continent the strongest, the most prosperous, and the happiest part of the globe.

Mr. President, if this reciprocity measure is to be beaten, I hope it will be beaten in Canada rather than here. I hope it will not be beaten there; I do not think it will be; but let it be there rather than here, for the sake of the future, for the sake of the continuance of that good old agreement under which we have been for nearly one hundred years without armament upon the Lakes.

Mr. Dillinginam. I want to ask the Senator from New York, if he can do so, to tell the Senate when in the last sixty years Canada has ever expressed a willingness for reciprocity with the United States in anything outside of natural products?

Mr. Root. Mr. President, I am unable to answer the Senator's question in detail. I know that Canada has frequently asked for reciprocity and has been met with indifference. 
Mr. Dillingham. May I ask the Senator a further question?

Mr. Root. Yes; but let me finish answering the question the Senator has just asked. I know the subject was up for consideration in 1905; I know that it was up for consideration at the hands of the Joint High Commission in 1898; and in a few minutes, if I could go to the volumes of Foreign Relations, I could look up a number more; but I was quoting from a Senator who spoke here the other day, the Senator from Michigan [Mr. Smith]. It is true that Canada has of late years, and perhaps always, put her special stress on natural products, but that does not at all vary or interfere with the proposition that $I$ have just made.

Mr. Dillingham. I have seen it stated in the public prints - I do not know whether it be true or not - that in the negotiations between the two Governments which have resulted in this agreement, the United States offered to Canada free trade in manufactured articles as well as in natural products, and that Canada, following the doctrine she has held for sixty years, ever since the abrogation of the treaty of 1854, absolutely declined to go further than as appears in this agreement, which is confined substantially to natural products.

Mr. Roor. I have no doubt that our Government was desirous of going further, and I will contribute to the discussion the interesting statement that the American commissioners in the Joint High Commission of 1898 offered to Canada free trade in all things upon the trifling condition that Canada would adopt our tariff, which naturally formed a disagreeable impression in the minds of Canadians, and which, of course, they were unwilling to accede to.

Mr. President, there is an amendment proposed to this bill. The Senator from Mississippi [Mr. Williams], with that can- 
dor and courage that naturally accompany so acute a mind and so great ability as he has, has relieved me of any necessity of devoting very much time to explaining the relation of that amendment to this bill. I wish simply to state very briefly what it is. The agreement contains a schedule called Schedule A, and I now read from the heading of the schedule:

\section{SCHEDULE A}

Articles the growth, product, or manufacture of the United States to be admitted into Canada free of duty when imported from the United States, and reciprocally articles the growth, product, or manufacture of Canada to be admitted into the United States free of duty when imported from Canada.

Under that heading in that schedule were enumerated a great number of articles, including pulp and paper. The bill, which was originally introduced in the House of Representatives, followed that schedule by providing for the free admission of those articles into the United States, with the condition that the President should find and proclaim that a bill for their free admission into Canada had been enacted. That bill was for the agreement pure and simple. That bill, however, was amended in the other House by taking pulp and paper out of that enumeration which followed Schedule A, putting it in a separate section - section 2 - and dropping out the provision requiring the corresponding legislation on the part of Canada; so that, without any legislation on the part of Canada and without any provision being made for the free admission of our paper into Canada, Canadian paper would, on the enactment of the bill, subject to certain conditions stated, come into the United States free of duty.

Mr. Nelson. Does the Senator from New York maintain that the second section of this bill is within the scope and purview of the reciprocity agreement as outlined in the message of the President and sent to the Senate? 
Mr. Root. Mr. President, I maintain that it is not; and I was trying to explain why it is not. The Senator from Mississippi [Mr. Williams], in the remarks to which I referred a few moments ago, said on Monday last:

A great deal of importance has been attached to the idea that the Root amendment is in strict aceord with the agreement between the two countries. Now, I always like to argue things frankly, for two reasons: First, because it is an honest thing to do; and, secondly, because it is always the wisest thing to do. The President of the United States has made no concealment of the faet that the Root amendment does express the original agreement in so far as it was an agreement at all. The House knew it expressed the agreement, and because the agreement as it was made would have resulted in exaetly what $I$ have said, perpetually possibly, indefinitely certainly, continuing the hold of the International Paper Company upon the paper business of the country, the House ehanged it that far, knowing that when it changed it, it ehanged the agreement on the whole still further in favor of Canada, and that therefore Canada would not object.

That is a very fair statement of the exact situation. The amendment which I suggested to the Finance Committee and to which my name has been attached, was designed to put the bill back where it originally was, so that the bill would cover nothing but the agreement. To vote for that amendment would be equivalent to voting against the change of the bill that was made in the House and which added to the bill, in addition to the reciprocity agreement and beyond that agreement, a further and different provision, taking off the duty from pulp and paper, which the agreement did not require to be taken off.

Mr. President, it may be that, as the Senator from Mississippi believes, the provision of the House Bill taking the duty off of pulp and paper without any compensatory legislation by Canada is a better provision than the provision in the agreement. I am not going to discuss that now. I say that it may be that it is a better provision; it certainly is a different provision. 
I have become satisfied that the amendment which bears my name will not be adopted. For many different reasons a large majority of the Senate are going to vote against it, some because they want the bill to be bad, some because they are afraid the bill would not pass in another place if the amendment were adopted.

I am not going to discuss the question whether the duty ought to be taken off. It is a modest duty - practically ten per cent on the importation of paper-but I am not going to discuss the question whether it should be taken off. It evidently is going to be taken off, but I do not want it done under cover of the reciprocity agreement, and I am satisfied to have suggested the amendment and to have had it discussed here, because the discussion has stripped off the cover of the reciprocity agreement that was spread over this independent pulp and paper provision so largely by public misapprehension, although, I believe, honest misapprehension, on the part of great numbers of the newspapers of the country. There was also much misapprehension here in the Senate for a long time about it.

The amendment the House incorporated in the bill taking off this duty and making the wood-pulp and paper schedule a separate and independent proposition is going to pass, but it is not going to pass under any false pretenses, inadvertent or otherwise. It is going to pass because this Congress means to take that duty off, and not because it is a part of the reciprocity agreement.

Mr. President, now let me say one thing more, and I am done. I am and have been for the agreement, the whole agreement, and nothing but the agreement. The amendment made to the bill in the House, which I wish to negative by the amendment to which my name has bcen attached, has added to the agreement another separate and distinct tariff provision. I am against that for one reason, because I believe 
that if you make this reciprocity measure the vehicle for discussing all the tariff questions that can be raised, the bill will never pass. The bill as passed by the House in this respect, as I have said, may be better than the provisions of the agreement. There may be a hundred measures better than the provisions of the agreement. My friend from North Dakota [Mr. McCumber] can doubtless put his finger on some that he thinks better; my friend from Iowa [Mr. Cummins] on some that he thinks better; half the Senators here can do likewise. I was against the addition to the agreement of this separate tariff provision, and I shall be against the addition to the agreement of any other tariff provision; and I, with the very small number of Senators who vote for this amendment, will stand in a singular group of consistency, for we shall take the same view about all the proposed changes of this reciprocity agreement.

While I say I shall be against all amendments that may be offered, I wish also to say that I do not doubt that there will be some amendments offered which as separate and substantive propositions I should favor; I shall be against them because I think it is our duty, acting upon the soundest public policy and with the broadest judgment as to the benefit of our country, to pass this reciprocity agreement. When we have done that, at convenient and proper time, if, as the result of passing that agreement or the result of anything else that has happened or shall happen, justice and the public good require that further changes be made in our tariff law, my friends upon both sides of the chamber will find me trying to be reasonable and just in meeting their desires and striving to agree with their judgment. 



\section{ART AND ARCHITECTURE IN AMERICA}

\section{REMARKS AT THE ANNUAL DINNER OF THE AMERICAN INSTI- TUTE OF ARCHITECTS, WASHINGTON, JANUARY 11, 1905}

The four addresses following, delivered at widely separated dates, dwell largely upon one topic - the preservation of the ideals for the artistic development of the National Capital which inspired Major L'Enfant in his original plans, and James Hoban in his design of the White House. Mr. Root's deep interest in the subject was aroused by the fact that his official positions gave him immediate supervision of the plans and construction of several of the most beautiful and effective public buildings in Washington. He was thus brought into professional relations with his personal friends Charles Follen McKim and Francis Davis Millet, the architect and the artist to whom he justly awards a great share of the credit for the fact that definite steps were taken during this period, by the establishment of the permanent Commission of Fine Arts, to protect the future development of the Capital from meretricious architecture, and to preserve and safeguard the original plans for making it "the city beautiful." The cloquent eulogy of McKim, and the pathetic tribute to Millet - whose inspiring influence was not wholly lost in the Titanic disaster of April 14, 1912-reveal a side of Mr. Root's character and outlook which does not appear so clearly in the other addresses preserved in this series. His tribute to Thomas Jefferson, "the great exemplar of 'the simple life' of America", and to the Virginia statesmen - American gentlemen-who built and lived in typical colonial homes on the banks of the Potomac, may be traced to his own reverent affection for the colonial architecture of the bomesteads of his ancestors in New England and New York.

7 THE place in which we are met, and its traditions, are of 1 happy augury for the future of American architecture, which receives a new impulse tonight. Within a hundred feet of this room stands the church of St. John, which perpetuates the beauty and the simplicity of Latrobe's design. From the windows of the adjoining room one may look through the trees and catch a glimpse of the white porch of that building, relieved by our President from the stilted title, "Executive Mansion", and brought to its own familiar name, by which it is known among all the American people"The White House"; that ideal expression of the time 
when the fathers of the Republic lived; that inheritance of America from the genius of Hoban, selected by Washington to erect as the home of America's Chief Magistrate, the residence of an American gentleman, upon the banks of the Potomac; that perpetual embodiment of the spirit of the life which gave to the nation Washington, and Jefferson, and Madison, and Marshall, and Randolph - all American gentlemen, on the banks of the Potomac.

I thank Heaven that the White House has been preserved, restored, and protected against all discordant and overwhelming additions and constructions whatsoever; and against all garish display and inconsistent treatment; preserved as a precious monument of America's past for America's future, by the fine and reverent sense of art of that brother of our own, upon whose shoulders fell the mantle of Richard Hunt - Charles McKim.

At the foot of the slope, the brow of which we can see from this building, begins that stretch of land set apart by Washington and L'Enfant for the great avenue of green which was to stretch upon the axis of the Capitol on to the future monument on the shore of the river Washington loved, that avenue as yet not realized, but to be realized in the future, as the reverence of the American people for the past of the Republic and the loyalty of the American people to the high ideals of art which Washington appreciated and strove for become true and effective.

Tomorrow's sun (which is soon to rise) will cast over the great avenue that leads to this place the shadow of the Capitol wrought out of the work of Thornton and Iallet and Bulfinch and Hadfield, the architects who gathered their inspiration not only from the classic works of art, but from the love of country and the serene natures of Washington and of Jefferson. The place is full of the associations and the traditions of that day far past, a day back to which the 
people of our country are turning with ever more and more solicitous desire to gather the inspiration of the earlier time.

Those were great days when the colonies were made into a nation, and they were the beginnings of great days for architecture. From that period the State House in Boston, preserving the genius of Bulfinch, looks down today upon the Shaw memorial. From that day survive the state houses at Portsmouth and at Newport. From that day the City Hall in New York, embodying the fine and delicate art of the French Republic, looks up in its purity and its grace upon the Tweed court-house and the skyscrapers of lower New York! From that day there comes to us a message in the capitol at Richmond, in Monticello, in the University of Virginia, in many a fine old dwelling in Charleston, in many a colonial and Revolutionary structure preserved in quiet corners in the North and in the South; and as our nation looks back to gather renewed inspiration in politics, in social wisdom, in patriotism, it finds also that the fathers of the Republic had in their souls the conception of beauty. We find that republicanism, that democracy, that the government of the people did not mean to them things unlovely, did not mean squalor or ugliness or meanness, but meant all that was noble and beautiful in art.

In the midst of the wealth and luxury of our day we turn to the simplicity of earlier times. "Jeffersonian simplicity" is much in our mouths in these latter years, but Jeffersonian simplicity was the simplicity of true art. When the state house was to be built at Richmond, Jefferson was asked to secure a plan. Being in Paris, he set about it; but because of the slow communication of the times before the plan had reached Virginia the impatient people of Richmond had begun the erection of their capitol, and Jefferson wrote to Madison a hundred and twenty years ago (1785) this letter: 
To James Madison.

ParIs, September 20, 1785.

Dear Sir: ... I received this summer a letter from Messrs. Buchanan and Hay, as directors of the public buildings, desiring I would have drawn for them plans of sundry buildings, and, in the first place, of a capitol. They fixed for their receiving this plan a day which was within about six weeks of that on which their letter came to my hand. I engaged an architect of capital abilities in this business. Much time was requisite, after the external form was agreed on, to make the internal distribution convenient for the three branches of government. This time was much lengthened by my avocations to other objects, which $I$ had no right to neglect. The plan, however, was settled. The gentlemen had sent me one which they had thought of. The one agreed on here is more convenient, more beautiful, gives more room, and will not cost more than twothirds of what that would. We took for our model what is called the Maison Carrée, of Nismes, one of the most beautiful, if not the most beautiful and precious morsel of architecture left us by antiquity.

It was built by Caius and Lucius Cæsar and repaired by Louis XIV, and has the suffrage of all the judges of architecture who have seen it, as yielding to no one of the beautiful monuments of Greece, Rome, Palmyra, and Balbed, which late travelers have communicated to us. It is very simple, but it is noble beyond expression, and would have done honor to our country, as presenting to travelers a specimen of taste in our infancy, promising much for our maturer age.

I have been much mortified with information which $I$ received two days ago from Virginia, that the first brick of the capitol would be laid in a few days. But surely the delay of this piece of a summer would have been repaired by the savings in the plan preparing here, were we to value its other superiorities as nothing. But how is a taste in this beautiful art to be formed in our countrymen unless we avail ourselves of every occasion when public buildings are to be erected of presenting to them models for their study and imitation.

Pray try if you can effect the stopping of this work. I have written also to E. R. on the subject. The loss will be only the laying of the bricks already laid, or a part of them. The bricks themsclves will do again for the interior walls, and one side wall and one end wall may remain, as they will answer equally well for our plan.

This loss is not to be weighed against the saving of money which will arise, against the comfort of laying out the public money for something honorable, the satisfaction of seeing an object and proof of national good taste, and the regret and mortification of erecting a monument of our barbarism, which will be loaded with execrations as long as it shall endure. 
The plans are in good forwardness, and $I$ hope will be ready within three or four weeks. They could not be stopped now but on paying their whole price, which will be considerable. If the undertakers are afraid to undo what they have done encourage them to it by a recommendation from the assembly.

You see I am an enthusiast on the subject of the arts, but it is an enthusiasm of which I am not ashamed, as its object is to improve the taste of my countrymen, to increase their reputation, to reconcile to them the respect of the world, and procure them its praise.

Yours, affectionately,

Thomas Jefrerson.

That was the simplicity of the great exemplar of the simple life of America.

Since then we have passed through a dreadful period. The stern requirements of conquering a continent, the engrossment of hardened toil, withdrew our people from the consideration of the elegant and the beautiful in life which the Virginia planters were at liberty to cherish. In this period the first acquisition of wealth, bringing a longing for ornament, for something beyond the bare necessities of life, found the people untrained and ignorant of art. Basswood castles and sawed scroll work were the first expression of a desire for the beautiful. A multitude of men calling themselves architects covered the face of the country with horrible objects of ingenious distortion, including a vast number of libels upon that excellent lady whose name has been given to the supposed style of Queen Anne.

The American idea, that any American can do anything, prevailed in architecture. The simple dignity of the log cabin, born of its conditions, wedded to its environment, gave place to the meretricious adornment of the confectioner. The perfectly appropriate and charming little white house with green blinds, with a persistent survival of classical details at the hand of the good, honest carpenter, gave way to wooden towers and arches, and to cheap pretense. 
But a better day has dawned. The myriads of Americans who year after year swarm across the Atlantic and rush through Europe with the guide-book, seeing for ever so short a time fortress and castle, palace and cathedral, tower and arch, the great examples of art in the ancient and modern world, have come back with new standards. Gradually the standard of the people has changed. We have already done enough so that we can afford to be modest; we have already done enough so that we can afford to admit that every American cannot do everything.

It was reserved for the great city of the Middle West, by the example of that fair White City by the lake, which remains with us as a dream of Ionian seas, to lead our people out of the wilderness of the commonplace to new ideas of architectural beauty and nobility. The lesson of the Chicago exposition has gone into every city and town and hamlet of America. The architects now for the first time are beginning to have the nation with them.

The people of America are beginning to see that it is not necessary to be commonplace in order to have common sense. The people of America are no longer content that the multimillionaire in his palace, the great railroad corporation in its monumental station, the great banks and insurance companies and trust companies in their massive business buildings, shall be the sole inheritors of the beauty and the art which our fathers loved. They wish for themselves in the public buildings of municipalities and of states and nation to have the best results of time and the best attainments of genius. What the people desirc, their representatives in state legislature, in municipal body, and in the Congress of the United States desire for them. The art of our fathers, the art of our private citizens, is to be the art of our people and of our whole people. 
I say a better day has dawned. The reign of Mullet is over already. For our great public buildings architects are consulted, as Washington and Jefferson consulted Thornton and L'Enfant and Hoban for the Capitol and the White House. We have the inspiring spectacle in this city of the broadminded management of the greatest of our railroad corporations, which is represented at this board tonight by President Cassatt, voluntarily and cheerfully withdrawing from the public park of Washington the railway station and the railway terminals which stood in the way of the realization of the dream of Washington and L'Enfant; voluntarily sacrificing the material advantages of that position in the center of this great city, in order that art might have its perfect work and the plans of the fathers be wrought out to full fruition.

Again, besides securing the Villa Mirafiori for the American Academy in Rome, within the week a firm foundation of endowment has been made sure by the munificent gift of $\$ 100,000$ by Mr. Henry Walters, of Baltimore, and $\$ 100,000$ by Mr. Pierpont Morgan, of New York. No one can estimate the value to France of the two centuries during which the citizens of that nation were taught in the French Academy in Rome. It was one of Jefferson's cherished ideas that young men of America might become saturated with the ideas of classical art by study in Rome; and now we are beginning the enterprise through which America will no longer be obliged to take her ideas of classic art at second hand, but will go directly to the fountain source at the home of art, under the direct and cherishing care of an American institution maintained by American munificence.

My brothers of the American Institute of Architects, you are no longer to be as one crying in the wilderness. The people of America believe that they are building a state which shall endure for all time. They believe that they are 
building into its structure the best of politics, of social science, of patriotism, and of humanity. They believe that the hopes of mankind for the rule of justice and liberty and peace rest largely upon the development of the American republic. And they already know that as there is a simplicity and nobility in nature which lifts up the spirit of the poorest worshiper, there is a simplicity and a nobility in art which protects the richest of its votaries from the enervating and debasing influence of a purely material life of wealth.

They would have every expression of American ideals the noblest and the best; and they would leave to the generations that come after them an expression of their patriotism, of their aspirations, of their faith in humanity and in divinity in structures as truly representative of the greatness and the nobility of the American nation as the cathedrals of the Middle Ages are representative of the aspirations of their builders.

It is for you to answer the demands of a great people with great ideals, and in answering those demands you will have with you in the future the people whom you serve. 


\section{CHARLES FOLLEN MCKIM}

\section{ADDRESS AT A MEMORIAL MEETING, NEW THEATER}

NEW YORK, NOVEMBER 23, 1909

When Charles Follen McKim died, September 14, 1909, memorial meetings were held in New York and in Washington, both of which were addressed by Mr. Root. Both addresses were short, and both are reprinted below, because each throws a somewhat different light upon the character, the genius, and the services of the great architect.

THE very few words which the requirements of the pro-

1 gram permit from me should properly be in recognition of Charles McKim's public service. Without ever holding a public office, without ever binding himself to service by an oath, he had the genius of public service. In the building of the Army War College at Washington, in the plan and construction of the Engineers' School, in the design for the enlargement and rebuilding of the government station at Governor's Island which is now in progress; in the restoration of the White House, which saved our country from having that noble expression of the spirit of the days of Washington and Jefferson perverted from a gentleman's home on the banks of the Potomac to garish mediocrity; in the making of the great plan for the future of the Metropolitan Museum of Art; in the organization and promotion of the American Academy at Rome; in the long years of patient and devoted labor in the great and monumental work of the Commission for the Extension and Perfection of the Park System of Washington, which has revivified and given life to the great designs of L'Enfant and Washington; in the numerous cases in which we used to call upon him to help our incompetency in deciding upon designs for buildings and for memorials and monuments in the National Capital; 
in all of these things and in the multitude of other matters that did not come within my personal observation, he was apparently indifferent to personal credit, thoughtless of emolument, inspired by patriotic, humanitarian love not merely of his art, but of the mission of his art.

As some men have the vision of their country rich and prosperous, and some men the vision of their country great and powerful, his imagination kept always before him the vision of a country inspired and elevated by a purer and nobler taste; and unselfishly, with enthusiasm, with persistency and high and noble courage, he devoted himself to that work. The sensitive quality of his nature which made him shrink from conflict, from all the harsh contacts of life, made the prosecution of this work by him courageous beyond the ordinary capacity for conception. That gentle, diffident and hesitating manner seemed always to be yielding to opposition and before assault; but always, though he swayed to and fro, always he stood in the same place, immovable, however much he suffered, - and he did suffer, - however hard it was, he never could surrender what he believed to be right in art. He never could surrender. It was impossible for his nature to yield what he believed to be best for the future of art.

Gentle and heroic soul, happy country which has the character to recognize such a man, which has the fiber into which can be woven such a thread! Fortunate are we to have known him and to have called him our friend.

ADDRESS AT A MEMORIAL MEETING OF THE AMERICAN INSTITUTE OF ARCHITECTS, WASHINGTON, D. C., DECEMBER 15, 1909

A Great meeting was held three weeks ago in the New Theater in New York, called by the united action of a great number of societies devoted to different branches of art, for the purpose of voicing their universal sentiment of honor 
to the memory and mourning for the loss of Charles McKim. At that meeting I said what I had to say in tribute to his memory, but I cannot resist the feeling that it is appropriate that it should be supplemented by this meeting here, held under the auspices of the American Institute of Architects, representing his own profession and the brethren among whom he had worked with such loyal friendship and coöperation for many years, and held here in the city of Washington, where, notwithstanding all things that he has done elsewhere, it seems to me, the brightest and loftiest development and expression of his character and his genius occurred.

Charles McKim was a conspicuous member of the little group of men who in the planning and building of the White City by the lake at Chicago, sixteen years ago, turned the current of American feeling and opinion upon all matters of art. No greater epoch in the life of art ever was than that which is marked by the influence and the new impulse in the minds of the millions of men and women of this great and rich and powerful and progressive country, who received a new impression of beauty and dignity in art by their visit to that wonderful exhibition. It has seemed to me that there was as great an influence upon the minds and characters of the men who did the work as there was upon the people who saw it and learned its lesson. There has been with all of them, and notably and preëminently, I should say, with McKim, from that day forth a breadth of public spirit and devotion of their art to the public service such as we never had before. Charles McKim was peculiarly fitted by the habit of his mind, by his character and by the tendencies of his art to correct some of the chief faults of the American temperament. He despised and shrank from the merely ingenious and fantastical, through which amateurs in the beginning of a desire for ornament are apt to 
express themselves. The tendency was to hold fast to all that was good in the past, to anchor in the great achievements past, and to aim to adapt the established principles of art to the new conditions to which his problems related; and so when he came - when he was called to apply his art to the solving of the problems that lay before us in Washington, it was natural for him not to attempt some great and brilliant achievement, but to study the history of our country, and to study the history of the arts that could be brought to illustrate and express the history of our country here. The Commission for the Development of the Park System of Washington did not attempt to evolve something from their inner consciousness, or to present some plan which should be marked by their names and lead all the world to praise their ingenuity or their inventive genius. They went back to the plans of L'Enfant and Washington, and with them in mind they went all over the world and studied all the great specimens of the past through which similar problems had been worked out, and they brought here upon their return the wealth of all the ages and a keen appreciation of our own history, and produced a plan and development of L'Enfant's plan for the beautification of Washington, for the development of its park system, which $I$ believe is as certain to be followed as the sun is to rise tomorrow. Unfortunately, the immediate acceptance of the plan is hindered by a wretched little controversy about the authority under which it was created; but that is a temporary matter. We cannot go on forever rejecting the best work of our best men along the lines that our nation is following in all of our great and progressive cities - we cannot go on forever rejecting that because of a little quarrel over the authority out of which it arose.

Mr. McKim was consulted by the War Department when it came to the building of the War College and the Engineers' School in the old Washington Barracks Reservation. He 
made the plans and he put up the buildings. There was a charming illustration of his character in the course of that work. The construction was put in charge of a very able offieer of the Engineer Corps, who brought to it the rules and the traditions of a strict utilitarianism. For months it seemed as if there was an irrepressible conflict between the engineer and the artist; it seemed as if nothing but the brute power of the War Department could settle it. But as time went on the old story of the sun and the north wind with the traveller repeated itself. The gentle insistence and unswerving constancy of McKim carried the day, and it was but a short time before the engineer officer was the most ardent admirer and loyal follower of the artist, and all controversy disappeared, and the War College today seems to me to be a very wonderful and charming example of architecture, perfectly adapted to its purpose and expressive of the character of the institution.

When he came to repair or restore the White House, he found there were plans, plans which looked to the building of great pavilions at either end of the old White House. It would have been splendid, would have been much admired, would have redounded to the glory of any architect; but it would have dwarfed and pushed back into insignificance the plain, simple, old White House, and MeKim with his reverent spirit, his self-restraint, sought in the history of the White House and the history of the time from which it came the spirit in which he was to work. Time and time again he has come to me and talked about what he had found at Monticello, what he had found here and there all over the country in the way of remaining buildings that express the spirit of the time of Washington and of Jefferson. He sought for the foundations of the old east wing which was destroyed, I suppose, and never rebuilt after the fire of 1814 - at all events it had long disappeared - and he put back the White 
House as nearly as possible as it was originally, except that he took out all the poor material and put in the best material; he took out all of the gingerbread confectioner's work that had been put in in the course of years and replaced it by simple and dignified work, and he left us the White House a perfect expression, an enduring expression of the day of Washington and of Jefferson, a perfect example of an American gentleman's home on the banks of the Potomac.

I told him once of something that some one had said about the office building - the President's office building. There was general criticism, and the members of our Congress generally failed to see where the money had gone, because the great pavilion had not been kept; but the thing that I told him was that some one had said that the President's office building looked like a stable. "Ah," he said, "that is the best thing that has been said about it yet. I wanted it to look like a simple dependency of the main building, and this criticism shows that I have accomplished what I sought." It was not alone in the matters where he was directly intrusted with the prosecution of work as an architect or as a member of the Commission that he was of service. We got in the way of calling upon him for advice upon all sorts of questions relating to memorials, to statues and to buildings in the city of Washington, certain that his correct taste, his carefully studied views, would prevent any error being made. He was called upon to pass upon the designs for the Grant Memorial, which is now under construction, and he was called upon to pass upon the location, and a battle royal occurred over the design and a still more serious confliet over the location; but he was tenacious and unyielding in his contention for what he was sure was right and best, and he prevailed. When we came to build the new building for the International Union of American Republies, which is now nearing completion, fronting on the White Lot on the east 
and on the Potomac Park to the south, there was a great competition of more than a hundred architects who sent in competitive designs, and they elected Mr. McKim, with Mr. Lord and Mr. Hornbostel, to make the selection from the designs. They all agreed upon the design, which is now being followed, and when that had been done the characteristic occurred, for McKim said: “ Now, I would like very much, as this design has been determined upon, to make some suggestions. I think that all of our committee would be glad to go over these plans with the architects, and possibly we may make criticisms and suggestions which would better be done now than after the building is put up "; and the architects, of course, were delighted and they submitted their plans; many invaluable suggestions were made, the plans were worked over and still again; and the correct taste of McKim goes into that building also, as it had into the White House, as it did into the War College, and as it will ultimately appear in the great park system of Washington.

Our President needed to add nothing to the many reasons that I have for respect and affection for him, but he did add to both of those by the steadfastness and generous appreciation with which he stood by McKim in his strenuous efforts to prevent the park system plan from being overslaughed and rendered impossible by subsequent inconsistent construction.

All of this work illustrated not only McKim's character as an artist, but his unselfishness, his love of his country, his pride in the capital city, which we all believe is to be so beautiful and so noble. He did love his country and he was willing to spend himself without stint, in order that his art might do its part in a noble and adequate expression of all that was best in his country's life. Many great and noble lives have entered into the structure of American government and American freedom, but none in executive chair or in legislative hall deserves a higher meed of appreciation and 
grateful recognition for noble service to our country than the life of Charles McKim. It was the last thought in his mind, but it should be the first in ours. By the side of L'Enfant, Thornton, Hoban, Latrobe, and Bulfinch, the name of Charles Follen McKim should always be perpetuated among the builders - the great genius-gifted builders - of what is to be, I believe, the most noble and beautiful city in the world. 


\section{FRANCIS DAVIS MILLET}

REMARKS AT A MEMORIAL MEETING OF THE AMERICAN FEDERATION OF ARTS, WASHINGTON, MAY 10, 1912

$\mathrm{T}^{\mathrm{T}}$ is known to all of us that in this place and at this hour 1 Francis Millet was to have contributed to the meeting of the National Federation of Arts a lecture upon the Art of Design.

Instead, the shadow of appalling tragedy has fallen upon us. Instead, there is silence never to be broken, absence that will know no return, a sense of loss irretrievable, and the need for readjustment to a world without our friend and teacher. Nevertheless we have kept our appointment. We have come to meet the memory of our friend. That is here, living, strong, vivid, and thrown into relief by the peculiar circumstances of this meeting.

We have come not to do injustice to Francis Millet's example by mourning and lamentation, but to celebrate the achievement of his long and useful and joyous life. He possessed in a very high degree many of the qualities which men at their best, in their noblest moods, most delight to honor and most sincerely believe to be a part of the saving grace of the world. He must have been born with a sense of the beautiful and a love of it, for he devoted his life to it, and never for a moment did the desire for wealth or place or power or distinction turn him aside. He must have been born with a natural sympathy for his kind, because, throughout his long, eventful career, with all its widely varied experiences, he never failed to appreciate and grasp an intuitive knowledge of the attitude, the feelings, wishes, prejudices of 
others. He had a singular capacity for winning his way without making enemies, for making friends of his opponents by overcoming them. He was one of the most modest, unassuming and unselfish of men. He never pushed himself forward. He never thought nor cared where the spotlight was. It never occurred to him to think whether he went through a door before or after another. He thought very little about himself and very much about his work. Yet from somewhere among his forbears in old New England there came into his make-up a firmness of fiber which made him, modest, sensitive, beauty-loving as he was, a man of strength and force, decision of character, and executive capacity.

Drummer-boy in the Army of the Potomac; graduate of Harvard; art student at Antwerp; secretary of the Massachusetts Commission to the Vienna Exposition; war correspondent in the Russo-Turkish war; director of decorations and of functions at the Chicago Exposition; war correspondent to the Philippines; chairman of the National Commission to Preserve the Beauty of Niagara Falls; chairman of the Advisory Committee of the National Museum; vice-president of the Municipal Art Commission of New York; commissioner-general of the United States to the Tokyo Exposition; trustee of the Metropolitan Museum of Art; a founder and the secretary of the American Federation of Arts; secretary and active executive officer of the American Academy in Rome; vice-chairman of the National Fine Arts Commission; author, painter, always a painter earning his living by his brush; knowledge of men and cities, experience in many affairs of life, had trained his intelligence and his judgment, had made him wise and considerate and tolerant and kindly. He read and appraised character without disparagement and without cynicism. With constant industry, with ungrudging willingness to take trouble, with incomparable persistency, in his quiet, simple, direct way he always 
pressed on toward the accomplishment of his purposes purposes in which self was always subordinate and some cause which he had at heart was always predominant. The enumeration of his engagements shows the estimate in which he was held by others, for he never sought the posts of honor and difficulty which he held. They always sought him because he was thought by others to be preëminently the man for the work. Other countries conferred decorations upon him - France, the Legion of Honor; Russia, the Military Cross of St. Anne and St. Stanislaus; Rumania, the Iron Cross; Japan, the Order of the Sacred Treasure. His own people conferred upon him unpaid labors for the public good. No one ever heard from him about the decorations and no one ever heard from him any claim to credit for the duties performed. He was one of a little group of American artists whose coöperation in the noblest spirit of unselfish love for art produced the Court of Honor and the White City on the shore of Lake Michigan in the Exposition of 1893. The great educational effect of that wonderful creation upon the millions of Americans who visited the exposition began a new era in the attitude of the American people toward art. It also produced a new spirit in its creators. The men who accomplished that work never cancelled their enlistment in the public service. They never severed the bonds that held them together in the desire that their countrymen might acquire the increased capacity for happiness which comes from the cultivation of taste. They were inspired by a conception of their country adorned and dignified by noble and stately buildings and beautiful parks and exquisite works of design, by painting and by sculpture. They have labored incessantly for the accomplishment of their ideas. The influence of their spirit has wrought powerfully among all their brethren in the arts. It has affected the public mind, and from the Court of Honor and the spirit of the men who 
made it and the work of the men who made it, came the chief impetus which produced the unprecedented growth of our art museums and art societies - the Washington Park Commission, the National Art Commission, the municipal art commissions in all our cities, the American Academy in Rome, and this Fine Arts Federation.

I will not name the members of this group who, happily, still survive, but there was one whose gentle and beautiful soul inspired all the others, the beloved and lamented Charles McKim. Between him and Millet there was a peculiar comradeship and affection; and the friendship of Charles McKim was in itself an order of nobility. The dearest object of McKim's later years was the establishment and development of the American Academy in Rome, through which his own countrymen might receive at first hand, under the most favorable conditions and surroundings, education and inspiration in those principles of art to which his life had been devoted. For this McKim labored unceasingly with his failing strength, and Millet took up the unfinished work as a sacred duty to the memory of his friend. It was in the prosecution of this work that he met his death. In a long letter that Millet wrote me from abroad just after leaving Rome in January last there are some paragraphs which illustrate his character. There had been trouble and discord and necessity for changes and reorganization in the institution, and Millet had gone to Rome to put an end to dissension and carry through the reorganization. After giving account of the many difficulties and the way in which they had been surmounted, he writes:

After a good deal of cabling and writing $I$, at the unanimous request of the executive committee, consented to take this position (the secretaryship), painfully conscious that whatever talents I may have as a lieutenant do not in the least qualify me to be at the head of anything, and also quite unable to see how I can arrange my affairs, earn my living and do this work. 
But he says:

Everyone now agrees that the situation on the Janiculum is incomparable, that the Aeademy will be "in the presence of Rome" even more than the French school in the Medici, and when the dormitory and the studios are built we will have an institution of an importance and utility that even McKim with his great faith could scarcely have imagined.

And then he adds:

Altogether the future looks bright to us after all these years of struggles and flounderings, and I feel that we shall carry out McKim's ideas to the full, perhaps even more.

Here speak the two dominant characteristics of the man the instinct of unselfish service, and the instinct of loyal friendship.

He was so great a part of many good enterprises, so devoted, so able, so skillful, so efficient, that it is hard to see how we can get on without him. Of course, everything will go on and he will soon be forgotten, as we shall. But he will not be forgotten so long as we live who knew him and loved him, and for all time, in whatever of nobility and beauty there may be in American life and character, there will remain something of the spirit and service of Francis Millet. 



\section{THE PLACE OF CARDINAL GIBBONS}

ADDRESS AT THE CARDINAL GIBBONS CIVIC DEMONSTRATION BALTIMORE, JUNE 6, 1911

$\mathrm{T}$ is a privilege to be permitted to add a few words to the 1 tribute which Baltimore and Maryland and the country are paying to Cardinal Gibbons today. Words, however eloquent, are but feeble in expressing the meaning of such an assembly as this. The fact that not only the friends and neighbors of Baltimore are gathered here, but that these representatives of all parts of our country, many of them a large part of them - of different religious beliefs, many of them representing communities widely differing in their religious faith, have come to join in this expression of respect and reverence for the great prelate, shows, more than words can show, the deep significance of this occasion. However, Your Eminence, and my friends of Baltimore, the gathering hcre means more than personal opinion or feelings, - means that America can do what was impossible in lands less free and ages less trained in humanity. It means that our American doctrine of separation of Church and State does not involve the separation of the people of America from religious belief. It means that our American doctrine of religious toleration does not mean indifference to religious faiths. It means that with all our commercialism, with all our wonderful progress in the power to produce wealth, with all our differences between ourselves as to the possession and distribution of wealth, the people of America believe in ideals and feel the guidance of faith in things higher than their material position. 
It is because Cardinal Gibbons has illustrated in his life, in his conduct, in his arduous labors, in his self-devotion to all good causes, has illustrated all that we would like to have our children admire and follow, all that we love to believe our country possesses, that America, through us, with sincerity and ardor, honors him today. And it is because he has been the champion of ideals, because he is a man not only of work, but of faith, that we who differ with him in dogma, who do not belong to his Church, hold him in his proper person, illustrating the true union of service to State and service to God, the true union which makes the functional and ceremonial union of Church and State unnecessary, the union, in the heart of man, of devotion to country and devotion to God.

It is because he is both a great prelate and a great citizen, because under his guidance his church, his people, and his followers, have always stood, and now stand, a bulwark against atheism and anarchy, against the tearing down of those principles of morality and of government upon which the opportunities of our country depend; because, while he brings the prosperity of our peaceful order to the service of his Church, he brings the faith and leadership of his Church to the maintenance of peace and order, that we all honor him and wish for him many a year to come of healthful, honored, and revered life. 


\section{JOSEPH G. CANNON}

\section{ADDRESS AT A DINNER IN HIS HONOR AT WASHINGTON FEBRUARY 15, 1913}

Honorable Joseph G. Cannon, represented the Danville, Illinois, district in the Forty-third, Forty-fourth, Forty-fifth, Forty-sixth, Forty-seventh, Fortyeighth, Forty-ninth, Fiftieth, Fifty-first, Fifty-third, Fifty-fourth, Fifty-fifth, Fiftysixth, Fifty-seventh, Fifty-eighth, Fifty-ninth, Sixtieth, Sixty-first, Sixty-second Congresses. He was chairman of the Committee on Appropriations in four Congresses and was Speaker of the House in four Congresses. In 1912 he was defeated for reëlection, and this speech was made at a dinner in his honor, on the eve of his retirement. In $1914 \mathrm{Mr}$. Cannon was again elected to Congress, and again in 1916.

MR. TOASTMASTER, Mr. Chairman, and my dear 1 Uncle Joseph, I am glad to congratulate you upon your approaching vacation. If any man in this world, by reason of truly religious service, is entitled to a sabbatical year, you are entitled to it after this long period of public service.

I know that it is only a vacation, because if the people of the Danville district do not get over their brief aberration within two years, you have only to come to New York and I will turn over to you a place in the other coördinate branch of the legislative department of the government where you can exercise the salutary influence by which you have made the House of Representatives the great and efficient body that it is.

I am glad to congratulate you, not only because there are a thousand reminiscences that make me feel kindly to you, as men who have fought together do feel toward each other, but because you are real.

There is nothing in public life, I think, of which a man gets more tired than of lying and humbug. It is very hard for all of us to talk to people from a public stage as we talk to each other. It is very hard for all of us to tell the truth when we 
are talking to the people. It is very hard for all of us to tell the truth when we think it will hurt us. It is very hard for all of us to keep our promises. But in the world of humbug, I am glad to do honor to a man who has always had the courage of his convictions, the courage to say what he believes, to say nothing that he does not believe, and to act according to his convictions.

I remember some years ago saying that if Uncle Joe were not so old, nothing on earth could keep him from being nominated for the Presidency - and it was true. All of a sudden came along a situation in which he was called upon to act at the behest of great and powerful influence, and he refused, because he did not think it would be right to do it; and then was begun the cry of "Cannonism." He has outlived it. I would like to hold up for the contemplation of the people of the United States the example of this man, who dared to become unpopular by doing what he believed to be his duty, and who has outlived it.

There is another reason why I am glad to do you honor because you stand for all the people of the United States. Your own experience in Congress, the variety of positions you have held, your long service as chairman of the Committee on Appropriations, called upon to consider the interests of every part of the country, your long service as Speaker of the House, have made you the representative not alone of the Danville district, but of the people of the United States.

Let me say to you, my friends of the Senate and the House who are here, that the great reason why the Executive is able so frequently to command the sympathy of the people of the United States against Congress is that the people think we are representing our selfish local interests, while he represents the whole people; and for the dignity, the influence, and the power of the legislative branch of the United States Govern- 
ment it is well for us to do honor to the man who represents not alone his own district but all the people of the country.

I am glad to do you honor for another reason - because looking about me and seeing standpatters and progressives and democrats of all shades and stripes of opinion, I see in this meeting that we are not becoming Mexicanized; I see in the fact that we all do honor to the hardest hitter, to the boldest Speaker, to the man who has never hesitated to express and stand by his opinions, however they might differ from the opinions of others, I see in this general concurrence of honor and affection for him, that still underlying all the storm and stress of American polities is the genuine American spirit of brotherhood toward all Americans. 



\section{A TRIBUTE TO THEODORE ROOSEVELT}

ADDRESS AT A BANQUET IN HONOR OF THE SECRETARY OF WAR UNION LEAGUE CLUB, NEW YORK

FEBRUARY 3, 1904

$T^{T}$ is good to be home again, good to be back in the place 1 about which are gathered the sacred associations that came to us in the flush of young manhood. One of you said to me tonight, taking my hand in the other room: "You look like old times." Old times, I thought, are good enough for me. The dear old times that go back beyond the foundation of this already old club-house, so simple in comparison with the palaces of later years, and yet so dignified by high ideals back to the old days, to the old place on Madison Square, where we felt the first strong impulse of the men who combined to save and perpetuate the Union. And yet old times pass away. During the short period, less than five years since, being still your president, I was called from my home to help hold up the hands of our beloved President McKinley; during that short period how many a beloved face has vanished, - Richard Butler, and Wales, and Dodge, and Fuller, and Evarts, and many another we shall see no more; and I cannot come back to join the friends of early youth, the friends and loyal associates of the long struggle of life, to march with them through the few short years that remain, without feeling that stirring of the heart which excludes the cold activity of the mind.

I come back, my friends, with renewed devotion to the principles that underlie and justify and account for the existence of this club. I come back able to say to you that 
the closest and most intimate association with two great men who have held the Presidency of the United States, has brought not that contempt which is said sometimes to result from familiarity, but much increased respect for the dignity of the office, and increased confidence in the stability of the institutions which we love, in a country which can bring to the seat of the chief magistrate men like them. I come back from a position in which criticism of representative government, criticism of the legislative branch, is most easy and most natural, for the legislative branch of our Government is always a drag upon the exercise of executive power. The executive is always asking appropriations, asking enabling acts, which the legislative branch is unwilling to give; the executive is always open to the suggestion of unnecessary legislative delay and vacillation, and failure to appreciate the exigencies of government, failure to appreciate the importance of doing what, to the men who are charged with the duty of conducting the government, seems of the highest importance. And I come back also from a period of exercise of wide and arbitrary power, for no power on earth is so arbitrary, so despotic, as military power; that power which enables the man who exercises it, with a single stroke of the pen, to make laws and unmake them, to sit in judgment superior to every court, and to execute the laws he has made and the judgment he has pronounced. Yet, I come back, I am glad to say to you who are wedded to the principles of popular liberty, with a deeper sense of the soundness and the beneficence of our system of representative government, with a deeper sense that arbitrary power, swift and effective as it is in its operation, should always be a thing of temporary expedient, adapted only to the time of war, and ceasing always at the earliest possible moment; and that the slow and tedious processes of discussion in our popular assemblies, the discussion that often seems to us to be unnecessary, 
is essential to the formation of equal laws, the preservation of liberty, and the advance of justice on earth.

Old times pass away, but the fabric of our free institutions stands. The majestic progress of this great people, growing ever in power and in influence throughout the world, continues. The impulse that came from the great struggle of the Civil War has not spent itself. Public administration, I believe, grows purer and better; public servants more unselfish and public spirited year by year. The people of our country conform, I believe, more closely, year by year, to the ideals of the fathers; and from close and intimate association, from careful observation of all branches of our Government, I come back to you to say that I believe that never before have the principles of this club, the principles of civil and religious liberty, the principles of government for the people and by the people, been better illustrated, more safely conserved, in the history of America, than they are now.

I have not felt away from home, I have not felt in a strange atmosphere, because during all this time $I$ have been in an atmosphere of loyalty and self-devotion. You may study the history of all the administrations from Washington down, and I challenge you to find in any a more complete loyalty and devotion to the President who had called the Cabinet together, to the principles of government which they were sworn to apply, than can be found among my associates in Washington during the administrations of McKinley and Roosevelt.

As we are growing old, as we are winding up our lives, the country goes on, the great mission - Liberty and Justice is working out towards its fulfillment. McKinley, dear to our hearts - dearer to mine than I ever believed any man could become after I had passed the meridian of life - has passed away, and another, a vigorous, virile member of this club, has taken his place. The problems that seemed to hang over 
us at the close of the war with Spain have gone far towards solution. We, of America, have discovered that we, too, possess the supreme governing capacity, capacity not merely to govern ourselves at home, but that great power that in all ages has made the difference between the great and the small nations, the capacity to govern men wherever they were found. Men trained to arms, men belonging to the class whom the Anglo-Saxon race has from time immemorial looked upon with doubt and distrust, men from the regular army, going among alien peoples, exercising arbitrary power and supreme control, have shown themselves most adaptable, most sympathetic and appreciative, not only of rights but of feelings and prejudices and idiosyneracies. Our army officers have become collectors of customs and internal revenue, governors of provinces, commissioners of charities, superintendents of schools, teachers - teachers not merely from books but teachers of the art of self-government; and in Porto Rico and Cuba and the Philippines they have proved themselves by the score, by the hundred, by the thousand, to be simple American citizens. Gold lace, epaulets and stars count for nothing. American citizenship has been demonstrated, and American citizenship as the citizenship which has deep down at its center, love of justice, of human freedom, of equal opportunity, and of progress, and helpfulness and happiness for mankind.

So the problems that seemed dark and doubtful when the war with Spain closed, have solved themselves through this working of a great multitude of Americans competent to govern. As your president has said, Porto Rico is a prosperous and happy community. Cuba, poor Cuba! that had struggled so long under intolerable oppression, has its star set in the firmament, and the new republic governs itself upon the principles of American freedom, - a new republic that has set its star in the heavens to lead on the republics of 
all Spanish America. And let me tell you that they see it in the heavens; all over Central and South America men are looking at Cuba and seeing what Spanish Americans can do when they have once learned the lesson of American freedom, ordered by law. And in the Philippines, where they knew not law - for there was no rule of law in the Philippines - where the poor, little brown men had never heard of aught but arbitrary power, they are beginning to learn what liberty means. They never knew what it meant. When they raised the cry of independence, they did not know what it meant. They are beginning to learn; and I look forward to the time when the Philippines shall assume towards this country substantially the same relation that Cuba occupies today. This could never have been done but by the excrcise of the power that rests in the word sovereignty. We never could have rescued those people from the turmoil and welter of savagery, the succession of military dictatorship following military dictatorship, under which the great body of the people would have had no choice except of tyrants, - but by the exercise of sovereignty; and through that sovereignty there has already dawned for the people of the Philippines the better day of liberty and law, which they are beginning to understand.

New issues have come. The old issues of five years ago have passed away. New questions are upon the horizon. But the principles and the character that were adequate to the old will be adequate to the new. We shall dig the Canal. And under the same honest and unselfish rule that has brought liberty and law to Cuba and the Philippines, by the peace, the prosperity, and the individual freedom that gather under our flag, guarding the neutrality of the Isthmus, we shall teach the people of Central and South America the same lesson, and shall give to them an example of how freedom ought to be used; and from that center of high 
example will come greater blessings to the Spanish American republics of Central and South America than they have ever yet realized from the unregulated freedom they won themselves from Spain.

I count it, my friends, one of the greatest privileges of my life to have been able, when that sad day came - the day that I cannot recall without the deepest emotion, when our President McKinley was taken away, - to have been able to stand by and hold up the hands of his true and loyal successor. I am told that he is not popular in the city of New York; that he, who was born and grew to manhood among us, old member of this club, who made his first essay in public life going to represent us in the legislature at Albany, more than twenty years ago, - that he is not popular here in the city of his home! I am told that some people say that he is not safe. I could not come back to you, come back to you between whom and me there have been no concealments for all these thirty-five years - and not say to you what I feel on that subject. Men say he is not safe. He is not safe for the men who wish to prosecute selfish schemes to the public detriment. He is not safe for the men who wish government to be conducted with greater reference to campaign contributions than to the public good. He is not safe for the men who wish to draw the President of the United States off into a corner and make whispered arrangements, which they dare not have known by their constituents. But I say to you that he has been, during these years since President McKinley's death, the greatest conservative force for the protection of property and our institutions in the city of Washington. There is a better way to protect property, to protect capital, to protect great enterprises than by buying legislatures. There is a better way to deal with labor, and to kecp it from rising into the tumult of the unregulated and resistless mob than by starving it, or by corrupting its 
leaders. There are some things to be thought of besides the speculation of the hour. There is the great onward mareh of American institutions; there is the development of our social system; there is the underlying faith and trust of our people in the laws under which they live; and the man who is put in the chair of the chief magistrate of this great people, President not only of you and me, here in New York, but of all the eighty millions of people scattered from sea to sea, charged under his high responsibilities so to administer the law that it shall have the respect and the confidence of the people who make the law, - he must take a view broader than the exigeney of the moment, broader than the business of the individual; he must see to it that he goes with the people who make the law, guiding them with wisdom and with strength, and guiding them always by the confidence that they have in him and the laws that he executes.

I have said that President Roosevelt was the greatest conservative force for the protection of property and of capital in the city of Washington during the years that have elapsed sinee President McKinley's death. He has been that indeed. I could give you specific instances where he has stood between the wish of men in Congress, who greatly desired to pass extreme and violent measures and the accomplishment of their purpose, by the strong and unwavering declaration, "I will veto your bill if you pass it"; and he has been able to do that because he was so fair, so appreciative of the rights and the feelings of every part of the great people whose President he was, that they trusted him, and he also dared to say, "I will veto an unfair measure against capital."

I have said there was a better way to protect capital than by buying legislatures; that there was a better way to deal with labor, and to keep it from becoming a mob, than by starving it. That way is, that capital shall be fair; that taking all the high rewards of brain, - of the inventive, 
discovering, organizing brain, all the rich, the magnificent rewards that come in this country of enterprise and boundless wealth to the brain that invents, that discovers, and that organizes, - yet capital shall be fair, fair to the consumer, fair to the laborer, fair to the investor; that it shall coneede that the laws shall be executed; that its treatment of the laborer shall be so fair that the reasonable and more intelligent men among the laborers of our country shall have their hands held up, their strength increased, their power to lead their fellows supported, and that they shall be enabled to hold the labor of America solid for American freedom, and shall believe in American freedom as against the demagogue and the agitator who seek to turn labor into a mob. Never forget that the men who labor cast the votes, set up and pull down governments, and that our government is possible, the perpetuity of our institutions is possible, the continued opportunity for enterprise, for the enjoyment of wealth, for individual liberty, is possible, only so long as the men who labor with their hands believe in American liberty and American laws.

And I say to you, my friends of the Union League Club, that our present President has, by fairness, by just sympathy with all his people, aequired the power to do more for the protection of the material interests, and for the spiritual interests of our country as well, than any man ever could have acquired by following the dictates of a narrow and limited view, which looked only to the speculation of the day, or the interests of particular enterprises.

The history of mankind is a history of growth in power, and growth in wealth, and growth in luxury, and then decay! And then despotism, alternating with anarchy! Take the large view of the statesman, and think of the future of America! The one thing that is needed, is not what you and I will make tomorrow, not the success of this or that corpora- 
tion, for next year, or the next ten years, or during our lifetime, but the perpetuity of our institutions, that our children and our children's children may live among a people devoted to American freedom and American justice. One thing necessary for that is that the great toiling mass of the American people shall feel that laws are just and justly administered; that every boy has his chance for the future, that the pathway to riches and honor and fame and power is open to him; that no class, be it consolidated by the unfairness of capital, be it consolidated by the unwise excesses of labor, shall bar him from the noblest birthright of liberty. And it is that, - it is that supreme and sacred interest that Theodore Roosevelt has been safeguarding in these years.

Property should be protected, capital should be preserved, enterprise should be fostered, liberty should be protected, the laboring man should have his fair wage. Yes! Yes! But for the sacred interests that gave birth to this club, for the perpetuity of the institutions which we love, for our children's children's sake, the one thing needful is that truth and honor and love of country, and the service of mankind, shall be the goal set before the eyes of the President of the United States; that the boys of America shall believe that the honest man, that the true man, that the loyal man, has honor in this land; that no arts of the politician, that no cajolery of wealth, that no social influence, that nothing but faithfulness to the duty of truth and honor and justice shall receive the supreme reward, shall win the great prize of popular approval, and shall rivet the esteem and the affection of the men of America. And I would rather have my boys taught to think that the finest thing in life is the honesty and frankness, the truth and loyalty, the honor and the devotion to his country of Theodore Roosevelt, than to have them in possession of all the wealth in this great metropolis. 
We are passing! This club goes on. Our country goes on. Whether the standards be low or high, whether they be the standards of the hour's expediency, or the standards of civilization's progress, time only can tell; but that they shall be the latter, the work of Theodore Roosevelt, as President of the United States, is more weighty than that of any one, of any score, of all of his detractors put together. 


\section{JOHN PIERPONT MORGAN}

ADDRESS AT THE MEMORIAL MEETING OF THE CHAMBER OF COMMERCE OF THE STATE OF NEW YORK, APRIL 3, 1913

$\mathbf{M}$ R. MORGAN'S life is still so near to us, the sense of loss, the half-realized idea that he whom we have been meeting here and there in the daily life of the present, is to be here no more is so vivid, that discriminating estimate is difficult.

Nevertheless, under the swift and sudden detachment of death we can already, vaguely, dimly, perceive his great career as a whole; the vigorous personality is seen against the background of tremendous forces whose play and conflict have been not merely the storm, but the development of an amazing half-century of progress for civilization.

When Mr. Morgan became a banker there was a different world than that in which we live. Then France was an empire. Germany was a geographical expression covering, by a reminiscence of history, twenty or more separate and independent states. America was half slave and half free. The continent was unspanned save by the emigrant wagon; no electric cable carried communication under the ocean; American banking was provincial and local; steamship and railway communication were in their infancy; the Bessemer process for making steel was not yet a success; manufacture was conducted by small units; capital was small; enterprise was individual. During his active life as a banker the most amazing development of wealth, of capacity for production, of commercial intercourse, of interchange among the nations of men, of transition from individual activity to the tremen- 
dous power of organization, the utilization of discovery and of invention, the power of leadership, all transformed the world of industry and of commerce, and are transforming the social life of the world. The transactions of today would have seemed impossible dreams half a century ago. The dreams have been realized in this single active life. This change has not been an invasion; it has not come from without, it has not been revolution; it has been development; it has been a growth from the latent forces that existed half a century ago.

This our friend whom we honor and mourn today, was the first, the commanding and controlling figure above all other men, in this amazing movement of the forces of civilization. First among all in our own country, emerging from its provincialism to its place in the great world of finance and industry, then by gradual recognition of his position here, first in the world, the greatest of bankers, the greatest organizer of production, the greatest master of commerce of the world in the mightiest epoch of power applied to finance, to production and to commerce.

How came Mr. Morgan to be this commanding figure? No title marked him for leadership to the common apprehension. No office created for him a presumption of greatness to the common apprehension. He had none of the arts of popularity. He had but little capacity for expression. In a country of speakers, of orators, of influence from the platform and of influence by the printed page, he was almost silent. It was only under stress of deep emotion that his power exhibited itself in words. The real man was hidden under a manner often gruff, always reserved. He was not a man of sentiment and expression, but a man of feeling and of action.

How came he to this leadership ? He had, first of all, constructive instinct. The instinct that moved him was not to 
accumulate, but to do. He cared little for money for itself. It was what he could do with it; it was to use it for good ends and objects of interest and desire, not to have it. Not the instinct of the miser, but the instinct of the builder, moved him always. He had, with this constructive instinct, extraordinary intuition. He did not reason by logical processes. His mind went, straight as an arrow, to its conclusion by processes that he himself could not have explained and of which he himself was not conscious, but it went with unerring accuracy. There is a field of the higher mathematics into which no man can enter, except those rare men who come once in a century and whose minds are capable of proceeding to a distant conclusion by processes unconscious to themselves. When such a man lives his name becomes great in the history of science. Such a man in the practical affairs of life was Mr. Morgan. The same kind of intuitive process or unconscious reasoning led him from his premises to his conclusions.

With that quality he had, of course, the quality of swift decision, so that opportunity never knocked in vain at his door. At the time when all things were possible, his decision came, and he had that high courage and inflexible resolution that gave to his decision the quality of absolute finality. An incident - perhaps a necessary incident - of this extraordinary quality of the man was that he carried a touchstone for all sham and deceit and pretense, like those rings of fable or of history, which could detect the presence of poison in the cup. With little evidence he needed no argument, he needed no deliberation, but he detected the true from the false, the sound from the unsound, and reached the bed-rock of a business question instantly. Naturally, with these qualities Mr. Morgan was direct and simple and frank; never cunning or devious, never wasting his time or retarding his progress by puttering about among little things, 
among trifles, he always went to the main question and decided that, and then let everything else follow that.

He had far sight into the future, he had breadth of vision and largeness of mind and comprehension, so that with these great qualities he became a great figure. He had more than these. He had that imagination which could visualize that imagination without which no one, poet or banker, reasoner or builder, can be great - he had imagination and he had faith, which not only was, but gave, substance of things hoped for. Take him all and all he was a man, - a great man. And with these qualities had he not genius? I think he had. I think no ordinary talent can answer the question why Mr. Morgan attained the leadership he did. I think it was that subtle and undefinable and rare quality of genius that made him what he was.

So he became a great leader in great affairs, and his name became a guarantee of soundness and honor and good faith and of success, so far as the exercise of inflexible resolution could produce success. He carried in his affairs the supreme capital of character. Under stress of excitement in the Pujo investigation he presented the great truth of character to the wonderment and confusion of smaller minds who had been thinking upon a lower plane than he stood upon. So he found the railroad system of this country the inheritor of the fruits of fraud and rapacity. Railroads that had been bled by their builders and managers all over the country he reconstructed upon the basis of absolute integrity, so that faith took the place of distrust and condemnation.

Mr. Morgan has been misjudged by many unfamiliar with great affairs who cannot see that big affairs proceed upon the same principles of morality as small affairs; and I would like to say - not to you in his own city who knew him, but to the people in every small town and village in our country: Select from among the people of your town the man who is most 
honored, the man to whom you would go for advice in distress, the man whose word every one believes, the man whose example every one desires his son to follow, and in this great citizen of New York you have the man that bears the same relation of faith and honor and good report to all the great affairs of the great metropolis, and of the world of finance and commerce.

Mr. Morgan played no game of chance; he acquired no fortune by deceit or over-reaching or unfair advantage. He took from no man, but he acquired a great fortune by making the prosperity of many and by taking his fair and just share of the prosperity he created. The scope of his enterprise gave him a relation to public affairs that was unexampled not only in our own country, but I think in any country. There were so many investors in so many enterprises whom his chivalric sense of honor led him to desire to protect that the financial condition of the country was a matter of immediate interest to him, and he took the place that Government should have taken many and many a time. The faults of our financial system, made possible by the incapacity of lawmakers to reconcile confidence and knowledge, he remedied from time to time as occasion arose by his own tremendous power; and that was government.

What Mr. Morgan did in the settlement of the coal strike, what he did in the panic of 1907 , was government as truly as the leadership of a nation acquired by one commanding figure who turns it into an army for conquest, or defense, is government. He followed the instincts of his nature which made him ready for public service wherever there was a public need appealing to his knowledge and his constructive instinct.

But there is another side of Mr. Morgan's nature which appeals to us, and that was his kindliness and generous impulse; the capacity for loyalty to every cause he espoused, 
that made him a staunch churchman, that made him a significant figure in all organizations in which we have known him, that made him a philanthropist and that made him a friend.

He was a great collector. He loved all forms of beauty. He had a sensitiveness to impressions - all the noble impressions of life that made him love association with what was great in literature, in history, and in art. More than that, he had a sensitiveness to all the noblest feelings that dignify manhood, which made his heart open to distress and suffering. Many men remain to be grateful to him for the preservation of their fortunes, of their investments, of the income upon which depend the comfort of their lives and the lives of their families. Many men, multitudes, remain to thank him for bringing to his own land, and helping to build up opportunity for the people to see, the great works of art of other countries and of other times, to thank him for that enlargement of human happiness that after men have drunken and eaten all they can and have worn all the clothes and found all the shelter they can, comes from the cultivation of taste. Many men remain to be grateful for his example of integrity and honor, and many men and women, to bless him for the good done in secret. Many a tear has been shed in homes of which I know for the loss of the simple-minded modest benefactor who has done good in secret.

The era of development in which he lived and worked is drawing to its conclusion. Such a career as his may, and probably will never come again, for we come to other days and to other manners; but the great-heartedness, the nobility of the man, thank God! are eternal, and will live with us and in his example, time without end. 


\section{JOHN MARSHALL HARLAN ${ }^{1}$}

ADDRESS AT THE MEMORIAL EXERCISES IN THE UNITED STATES SUPREME COURT, DECEMBER 16, 1911

I

BEG to second the resolutions which have been presented, and by doing so to pay the tribute of gratitude which every lover of his country must feel for a life devoted to its service with power and sincerity.

The passing of Mr. Justice Harlan severs the tie between two eras of our national development. When he came to the Court thirty-four years ago, he became a part of a court made up by the men of the great Civil War, all appointed by President Lincoln and President Grant, except one, Mr. Justice Clifford, who was the surviving connecting link between the Court of the war and of the preceding era in which he received his commission from President Buchanan. Justice Harlan was the sole connection between the Court of the war, the Court of Lincoln and Grant, with the new Court that faces the new problems in a new period of our national development; and as he goes, the old Court disappears and the new times confront us. There are clocks moved by electricity from some central station; their hands remain motionless as the minute passes, but at its end they move instantly to the next, and lo, another minute of time has come. As Mr. Justice Clifford passed away, the hand moved from the ante-bellum days to the period of war and recon-

1 Born in Boyle County, Ky., June 1, 1833. He was appointed an Associate Justice of the Supreme Court of the United States, November 29, 187\%, and died October 14, 1911. Only three members of the Supreme Court Bench have served longer terms than Justice Harlan, namely: Chief Justice John Marshall and Justices Stephen J. Field and Joseph Story. 
struction; and as Mr. Justice Harlan passed, the hand moved from the period of war and reconstruction to the new times and new problems before us. He, Mr. Chairman, was a conspicuous illustration of a truth so often exhibited in the history of American jurisprudence - often in that of England, more often in that of America - the truth that more important than learning, more important than the logical faculty, more important than all scholastic qualities, is the force of character, the sympathy with life, the capacity for measuring the needs and the impulses of constantly developing and changing life which come to the men who have been significant figures in great affairs, to men who are essentially human and who have dealt with great forces.

Justice Harlan did not reason abstractly about it, but his nature compelled him to illustrate the truth that in every judicial decision there are two primary elements: one is the ascertainment of the law, and the other is the application of the law to the human problems of the moment. He was intensely human, a natural contender, and he rejoiced in conflict. Life upon the bench never emasculated him. He never wrapt himself about with the mantle of over-sensitive dignity, which sometimes minimizes judicial strength. He asked for no subservience from the bar, and he rejoiced in the presence of counsel who stood up with manly assertion of a client's rights. His intense interest in the affairs of the world kept him young, and his youth maintained his usefulness. He could not lose his interest in the affairs of life. Sometimes, when in executive office, I myself have been struggling with difficult questions that were attracting public interest and public thought, his tall form would make its appearance in my office, and he would come in the kindly confidence of old friendship and sympathy, to tell me how, from his point of view, it would seem, and to warn me of dangers he could foresee. Sometimes he would say: "Be careful not to run 
against the doctrine of that or the other case in what you do."

And so he lived a full life to the end, rendering service for which no one could compensate, and for which we can only render that great appreciation which is after all more important for us than for him. For, to mark such a life and such a career of service with honor, in order that all men may realize their worth, is of primary consequence to the administration of our law, and the just exercise of our governmental powers in all departments for the future. No one can be a pessimist, no one can despair of his country's future who sees that such men as John Marshall Harlan can live in honor and can be appreciated by their countrymen. 



\section{MELVILLE WESTON FULLER ${ }^{1}$}

ADDRESS AT THE PROCEEDINGS OF THE BAR AND OFFICERS OF THE SUPREME COURT OF THE UNITED STATES

DECEMBER 10, 1910

TEE to second the resolutions which have been offered 1 and to express the adherence of the bar of New York to the sentiment of the resolutions and of the admirable remarks which have been made both by yourself as chairman of the meeting and by the chairman of the Committee on Resolutions. Some of us at the New York bar were very much disappointed twenty-three years ago that the choice of President Cleveland for the great office of Chief Justice did not fall upon our associate and leader, Mr. James C. Carter. It was a great disappointment to us; but we soon came to know the new Chief Justice; we came to realize the admirable intellectual integrity of a mind free from crankiness and flaws. We came to recognize the noble and beautiful character, the sweet and kindly sense of justice and consideration for all men. We learned to feel the influence of that benign presence on this great bench, and to feel that no one came here, however great or small, to speak for justice, who was not heard with an open mind and a kindly appreciation. We came to respect the choice of President Cleveland, and we came to love the man and honor the judge. So, there are no truer mourners by the side of Melville Weston Fuller's grave than the members of the bar of the state of New York.

The occasion calls for signalizing the greatness of the Court and the dignity of the great officer who has passed away.

1 Born in Augusta, Me., February 11, 1833. He was appointed Chief Justice of the United States, April 30, 1888, and died at Sorrento, Me., July 4, 1910. 
Not merely in pursuit of the interests which are represented in individual cases, but in our maintenance of the great principles upon which justice in all cases depends, we should emphasize the event which changes the possession of the greatest judicial office in the world. At either end of this building the public interests, the apparent public interests, the feelings, the wishes, the purposes of the moment may prevail, and within limits should prevail. At the other end of the avenue the execution of the law answers, and should answer, to the public will as expressed in the legislation of the moment. Here are preserved those great rules of right conduct, those fundamental principles which are essential to the perpetuity of free institutions, whatever may be the gusts or storms of public feeling, by that arrangement of our Constitution which is the chief gift of America to the science of government. Here are maintained the eternal principles of justice, and above all monarchs and presidents and legislatures, the sacred office upon which depends the continuance of self-government with peace and justice, is the office of the Chief Justice of the United States. We mark our reverence for the office. We mark our deep sense of its supreme value and dignity, as we join with our brethren of the bar in doing honor to him who has worthily and nobly, with a pure and beautiful spirit and an upright and vigorous mind, sustained that great office. 


\section{JUDGE JOHN DAVIS ${ }^{1}$}

\section{ADDRESS OF THE SECRETARY OF WAR AT A MEMORIAL MEETING OF THE BAR OF THE COURT OF CLAIMS \\ MAY 16,1902}

T $\mathrm{T}$ is with melancholy satisfaction that $\mathbf{I}$ find myself able 1 to appear before you to pay a tribute of respect to the memory of my dead friend by seconding the excellent resolutions now presented. The members of the profession practicing habitually at your bar have had better opportunities than I to observe the way in which Judge Davis performed his judicial duties and to estimate his qualities and merits as a judge. They have expressed themselves in these resolutions with sincerity and genuine feeling.

But my knowledge of him and my friendship for him go back to the days of his early manhood, long before he took his seat upon the bench, and when he was forming and developing in private station the character whose admirable traits have endeared him to you. Of all the qualities that determine the usefulness of a judge, the most important are those which go to make up the personal character of the man. Character upon the bench is of more weight and value than learning or reasoning power or industry or acumen, or all of these put together. Without it the most brilliant talents but disturb public order and undermine the foundations of justice. John Davis joined to superior intelligence a judicial character of the best type. He had the fine instincts of the gentleman - a shrinking from sham and pretense, from

1 Honorable John Davis, judge of the Court of Claims, died at his residence in Washington, Monday, May 5, 1902, in the fifty-first year of his age. He had been appointed to the bench of the Court of Claims, January 20, 1885. 
humbug and claptrap, an antipathy to mere hollow rhetoric and the clever devices that cover up the merits of a case, and a liking for the simple statement of a suitor's right.

He had genuine sympathy with his fellow-men, charity for their weaknesses, kindly judgment of their conduct, and a sweet and serene temper which forbade his being swayed into partisanship by passion or prejudice, or falling into harsh and unjust judgment; and he had the sense of honorable obligation, which makes it impossible for a judge, upon any consideration whatever, to withhold from a suitor the logical results of judicial opinion; which makes the intangible right that the litigant has to a conviction formed in the judicial mind, as sacred as property in chattels or in lands, and compels the judge to do justice as he sees it, though the heavens fall. His manifest sincerity and desire for justice strengthened the public respect for the law which he administered, and his grace and charm of manner robbed defeat at his hands of half its bitterness. It is a fortunate thing that such a man should have sat upon the bench of this great court during the formative period of its growth in jurisdiction and power, - this great court which represents the highest type of human justice, - not the justice of man to man compelled by superior power, but the justice of a great people whom no man can compel, voluntarily seeking to know what is just, in order that it may do justice. It is a fortunate thing that as the scope and importance of the court's functions widen with the ever broadening and multiplying activities of our country, and long after the bench and bar of this day shall have passed away, the benign influence of this true gentleman and upright judge shall live in report, in tradition, and in the character of the court of which he has been so great a part. 


\section{JUSTICE GEORGE CARTER-BARRETT}

ADDRESS OF THE SECRETARY OF STATE AT THE MEETING OF THE BENCH AND BAR IN MEMORY OF HONORABLE GEORGE CARTERBARRETT, NEW YORK CITY, NOVEMBER 10, 1906

FTER these admirable tributes to the memory of our friend of all my active life, and homage for a pure, upright, able, devoted public servant. How well I remember him on that day, nigh upon thirty-six years ago, when he stood at the bar and made the great argument that attracted to him universal public attention and led to his nomination and election to the bench of the Supreme Court! Young, slender, nervous, pale, trembling with energy and enthusiasm, he exhibited on that day, it seemed to me, qualities of greatness that would know no limit in their development, except the limit of life. I have often regretted that he went upon the bench; because it seemed to me that he had the qualities that would have made him so great at the bar, so great in the political life of the country, so great in diplomacy, so successful in any branch of active life.

Yet, I have always answered myself by the reflection that he brought those qualities to the bench. And it was the possession of the qualities that would have made him successful in the stir and activity of life that made him so great a judge. His control over juries was marvelous. The skill with which he directed the course of a trial was exquisite, admirable, a perfect work of art. He possessed a clear, definite conception of the duty of a judge in the trial of questions of fact, and it was one which I think worthy of admiration. He swung away freely and altogether from the fault, 
so common in our American courts, of treating the trial of questions of fact before juries as a game, in which the lawyers on either side are contending for a prize, and in which the judge acts as a referee between them. Mr. Justice Barrett's conception of his duty upon the bench was that he was to see justice done; that he was to require the counsel before him to arrive with all convenient speed at the determination of the merits of the case; and that he was to contribute his own convictions to the right solution of the question involved. In his dealings with questions of law he also illustrated a quality not always found upon our bench. He never allowed justice to be tangled in the net of technicality. His keen and incisive intellectual process never stuck in the bark. Words were nothing to him, but the ideas behind the words. And that sensitive appreciation of every interest in life which graced him gave him a just conception of the relations which statutes and rules of law, enacted or adopted perhaps a lifetime, generations or centuries before, had to the conditions of real life. He interpreted the law in the light of the living present, with all its mighty forces, with all the requirements of civilization, of morality and of justice in the world of today, and not in the light of centuries past. Thus he was often in advance of us all; his decision in the lower court in the Sugar Trust case - the North River Sugar Refining Company case - went to a length to which the Court of Appeals in the same case was unwilling to go, though affirming the decision. His decision in that case has found the bench and bar of the United States now, fifteen, twenty years after, just reaching his sound and just conception of the demands of the rule of the law - the immemorial rules of law - under the conditions of our modern life.

He was a great judge; he was a true and noble gentleman. To be his friend was to have a blessing in one's life. To know him well was to be made better by the compulsion of 
unconscious imitation. He was a warm and loyal friend. He will be forgotten! We cannot rescue his name from oblivion. We shall all be forgotten. There is no immortality of the bar, and there is, save in the rarest, most exceptional cases, no immortality of the bench. He will be forgotten! But so long as the recurrent waves of error beat against the structure of American liberty founded upon justice; so long as the corruption that he whipped seeks to undermine the structure; so long as the violence of the demagogue seeks to hurl the mob against it, - so long will the influence of that modest, retiring, unostentatious man continue to live in the work that he did in building up the structure. 



\section{JUSTICE CHARLES H. VAN BRUNT}

ADDRESS IN PRESENTING TO THE APPELLATE DIVISION OF THE SUPREME COURT OF THE STATE OF NEW YORK IN THE FIRST DEPARTMENT, A PORTRAIT OF THE HONORABLE CHARLES H. VAN BRUNT, FIRST PRESIDING JUSTICE OF THE COURT, JUNE 8, 1897

T TAKE great pleasure in seconding the application made 1 by Mr. Butler. It is perhaps too common to defer expressions of confidence in official servants until the obituary notice. The world is full of ill-natured criticisms; and the kind things, the expressions of commendation, are seldom heard. Many a judge goes through his entire official life without knowing with what confident reliance the bar and the community rest upon their belief in his justice, his intelligence, his devotion to the duties of his office; and I think it is a fortunate thing that at this point in the career of the presiding justice of this court, after almost a generation passed upon the bench, the approaching close of his official term has led to the presentation of this portrait, and has given an opportunity to say some kindly things and to make some expression of the confidence which the bar and the community do feel in him.

Mr. Justice Van Brunt has filled no ordinary place in the judicial history of this city. Many judges are learned; many judges are able; many judges are devoted to the public service. Judge Van Brunt is all that; but he has also played a great part in a peculiar and important stage of development in our judicial history. We have been, during the years of his occupancy of the bench, passing imperceptibly through a course of development from a provincial town to a great 
metropolis. We have been passing through the same kind of development which has changed the surface of the country about us from open fields, over which all the inhabitants could range at will, to enclosures which are carefully guarded and into which no intruders are permitted to enter; the same kind of development which has changed the old-fashioned railroad with its absence of rule, so conducted that any one could stroll into a station and upon a train without any questions being asked, into the carefully guarded railroad of today, with stations where every one is required to move in accordance with strict rule and to have his ticket punched at the gate, and is not allowed to enter or depart except in accordance with rigid and prescribed forms.

That same development has proceeded in our judicial life. Great complication requires rigid system. The old method of trying and arguing causes according to informal arrangements between judges and counsel has been outgrown. When Mr. Justice Van Brunt took the position of presiding justice of the general term, he found that the old method of transacting business had led to an enormous accumulation before that appellate tribunal. The result of the old country way - the good old way of doing business - was that it required between two and three years after the entry of a judgment, to obtain a decision by the general term. The administration of justice, if the whole machinery was not to break down and become a denial of justice, called for a man with sufficient vigor and commanding personality to make the change from the old method to the new method of rule and order. The occasion found the man in Mr. Justice Van Brunt. It was a hard experience for the bar; and in the earlier days of his presidency there was strong feeling, there was great dissatisfaction, there was personal resentment; but I think the entire bar, old and young, the entire community which receives its impressions from the bar, will unite with 
me in saying that the conseientious and consistent performanee of duty, the successful aecomplishment of the task which he set before him, has commanded the assent, the cordial agreement, and the admiration of all, no matter what their original opinions may have been. He has brought order out of chaos; he has brought the administration of the law to a point where justice can speedily be rendered; he has accomplished the great work which was necessary for the development of the law and of our judicial system in this great metropolis. And to him is due a degree of praise for that work which is due to no other judicial officer during your days or mine.

I hope that this expiring term will not be the last of Mr. Justice Van Brunt's judicial service; but that a just recognition of his worth and of the service he has rendered will lead the people of New York to continue him for many years in rendering a like service to the cause of justice, and that for many years we may be able to rely upon his sound discretion, his decision of charaeter, and his underlying sense of justice, for the determination of our clients' rights. 



\section{BUSINESS AND POLITICS}

ADDRESS OF SENATOR ROOT AT A RECEPTION OF THE UNION LEAGUE CLUB OF PHILADELPHIA, IN HIS HONOR MARCH 23, 1915

T is very difficult to respond to such expressions as I have 1 heard tonight, where my cooler judgment refuses to go in agreement, and where I know that a dispassionate stranger would withhold his approval. Such things as have been said within the past hour are, however, inexpressibly grateful to me, because they reveal the wealth of friendship and the partial judgment of affection.

I did not know until a few minutes ago of the purpose of The Union League to bestow this great honor upon me, in the gift of the medal of the League. I accept it with gratitude and deep appreciation which will continue during all of my remaining life. We confer no titles of nobility in this republic, but we do what is better: from the promptings of patriotic hearts we repay in double measure to overflowing, every debt which we think we owe to a public servant who has commended himself to our judgment as Americans. No title could be worth so much as your judgment; no office could be worth so much as your approval. And it comes to me with all the more weight because I have a sentiment for Philadelphia and its people, and for this club, that has continued through all my active life. A throng of associations compels me as I come into this old club-house to remember the good men, the strong men and the noble hearts that I knew in days past who are here no more. When I remember how great a part this organization has played in the strength and courage of this great land of justice and liberty; when I remember how much I owe and my children and children's 
children will owe to you, to realize that you are thanking me seems almost too much to believe.

I had been thinking, as I came over in the train this afternoon, of my associations with Philadelphia, and I found, strangely enough, that of all the dear friends $I$ have known here, my mind went back constantly to McKinley. I recall how, eighteen years ago, I came here upon a telegram to meet him, to talk about the condition of things in Spain. I remember how he said, " There is danger of war; there must not be war with Spain; there shall not be war with Spain. It must be and it shall be prevented at all hazards." Then I thought of how little any one man can do. The tendencies of the mighty eighty millions of people moved on along the path of their destiny, and even that great and skillful man with all the power of his high office could not prevent it. And I remember how, a couple of years after, one of my first journeys as a member of his Cabinet was to come here to this club to be with him in one of those great receptions for which you are so famous. And that led to reflection, not upon specific differences between President McKinley and this Administration, between the legislation or the policies of that time and this, but to reflection upon what in the retrospect can be seen to have been a great nation-wide movement along the path of the nation's unconscious purpose.

When we elected McKinley in 1896 and again in 1900, it was the business men of the United States who controlled the election. It was the general, the almost universal awakening of judgment on the part of men who carried on the great production and commerce and transportation and finance in the business of this mighty and prosperous country, which elected McKinley and inaugurated and maintained the policies of his administration.

How great has been the change. The scepter has passed from the business man. The distinguishing characteristic of 
recent years has been the conduct of the government of the country by men who have but little concern with the business of the country, by men who distrust the man of business, who suspect the man of business. Measures relating to the great business and the small and multitudinous business of the country have been framed and put into effect under influences which have rejected the voice of those whom they most immediately affect. The railroad man's testimony of what legislation there should be affecting railroads has been rejected, because he was a party in interest. The banker's testimony about finance has been rejected because he was a party in interest. The manufacturer's testimony about manufacturing has been rejected because he was a party in interest. The merchant's testimony about commerce has been rejected because he was a party in interest. The shipowner's testimony about the merchant marine has been rejected because he was a party in interest. Knowledge of the business affairs of the country has disqualified men from taking any part in the conduct of the increasing participation of the government in the control and direction of business affairs.

Now, this has not been accidental. It is not a matter of individuals. It has not come because particular men have been elected to office and other particular men have failed. It has been a development of the feeling of the whole country; it has been to some degree sectional, but not in the old way. The men concerned in agriculture, in the main, have come to suspect and misunderstand the men concerned in business in the main. This is the distinguishing feature of this great change which has occurred since we elected McKinley.

It has had several causes. It has been partly because of the old hatred of wealth. Those parts of the country in which all of the people have been of comparatively small means have been filled with men who came to hate the rich in the great 
industrial communities in the North and East. Of course I need not tell you that this hatred of wealth is more than half mere vulgar worship of wealth. God knows that too much money does no man any good; too much money is more apt than not to ruin his children and invite for him kidney disease or hardening of the arteries.

But to the poor farmer on the prairies of the West or the cotton-fields of the South, it seems as if the rich men of the Eastern cities were living in heaven at his expense.

Another element of this change has been an entire or an almost entire failure of understanding of the processes, the conditions, the requirements and the results of the vast and complicated business by which the wealth of the country is created and maintained. Under simple conditions we all understood each other. Every man of the community understood in general about the life, the business and affairs of the other men in the same community. But life is so complicated now, the affairs of this great country are so involved, that there is very little real understanding by one community of the affairs of another. How can the man who raises a crop of wheat in Dakota really understand the complicated machinery by which his wheat goes onto the breakfast table in Europe, and the price comes back to him ? So, through a feeling of envy of the greater wealth of the East and North, of these industrial communities of which this city is a conspicuous example, and through misunderstandings, there has come about a feeling of adverse. interest instead of the feeling of common interest that is so essential to the prosperity and perpetuity of a country. And that feeling has had its result in a series of laws and in the method of administering those laws. We have the Interstate Commerce Commission following every step taken by the great transportation companies. Understand, I am not now criticising these laws. I am citing them as elements - stating them as 
facts; but forming elements in a general condition to which they lead. We have the Interstate Commerce Commission keeping tab on the railroads. We have the Central Reserve Board of the Treasury Department and the office of the Comptroller of Currency following every move of the banks. We have the new Trade Commission which is empowered to go into your factories and mills and inquire into your personal affairs for the purpose of seeing whether you conform to that vague and indefinite standard which they are to apply to trade. We have the Internal Revenue Collector empowered to go into your personal affairs for the purpose of seeing whether your returns for the graduated income tax are full and complete. We have the Pure Food law, under which a vast range of production is subjected to inspection and regulation in the most minute detail. Everywhere, in every direction, supervision of business is the characteristic of the day.

And with the exercise of power over business under the Constitution as it is, comes the desire for enlargement of power, so we have proposals for amendments to the Constitution which will give to the national Government opportunity to extend and increase its control over the conduct of affairs in every state and in every locality. That finds its outlet first in matters that have much popularity. The proposal to amend the Constitution by putting in a prohibition amendment, is the first step toward national control of sumptuary laws directing what shall and shall not be done in every community; amendments to the Constitution in respect of the franchise, to direct who in every state shall or shall not have the right to the elective franchise. In general, the great industrial communities of the North and East are more and more being subjected to government control and regulation by the people of the parts of the country that know little of the business of the country. 
I say the scepter has passed. The control has changed, and it is impossible to resist the conclusion that there lies the reason for the stagnation, the hesitation, the timidity, the unwillingness of American enterprise today. You cannot say it was the tariff alone. You cannot say it is the restrictions upon the trusts, the suits against the trusts or the great corporations which are called the trusts, alone. You cannot say it is the Clayton law or the Trade Commission law alone. But the men who are controlling the government of our country today are men who have been fighting the tariff so many years; have been fighting the trusts, or what they thought were the trusts - the great corporations - so long; have been fighting the railroad companies, the express companies and the telegraph companies so long; have been fighting the banks and the bankers so long, that when they come to administer the Government of the United States they cannot rid themselves of an underlying hostility to American enterprise. Many of them are good and sensible men, and patriotic American citizens - friends of mine and friends of all of us. I have talked with them personally and they do not believe it, but it is true. Underlying all their actions is an uneradicated but not uneradicable hostility to the men who they think have profited unduly by the tariff, to the men who they think have unduly profited by the trusts, to the men who they think have profited unduly by the control of the banking funds of the country, and to the men who they think have made undue profits or dividends out of the railroads and the enterprises that surround the proper administration of a railroad. And the reason why business does not start is because way down in the heart of Americans there is a doubt as to what is going to happen at the hands of a hostile Government.

Now, what is going to be done about it ? It is not something to be disposed of by conquest. It is not something 
which we ought to be satisfied with disposing of by mere votes. Merely electing a Republican President in 1916 ought not to be enough. The country cannot live and prosper with such misunderstanding. The people who are doing these things are honest and good Americans, but they misunderstand a great part of the country. They do not realize that you do your business in the city of Philadelphia on the same principles that they use when they drive a load of wheat to the elevator or a load of potatoes to the nearest town upon no other principles, just as honestly and fairly. All the glamor of occasional wealth and the magnitude of operations have blinded them to the essential identity of the way in which they do their business and the way in which you do yours. I say that this ought not to be permitted to continue; this misunderstanding ought to be cleared away. It is a question, it is a serious question, it is a question again of preserving the Union, for we cannot live with that kind of misunderstanding between the people of one section and the people of other sections.

Now the first thing which is plain is that the business men of America, the honest, reliable, good, fair citizens who are doing the great business of our country, should become vocal and take pains to see to it that they are no longer misrepresented or misunderstood. What does an honest and fair man do when he finds that somebody whose good opinion he respects, misunderstands him ? He does not try to shoot the other fellow or injure him; he tries to remove the misunderstanding, and that is what we ought to do. The business men of America should wake up - get out of the condition of mind which they have been in for some time past, in which they have taken all sorts of misrepresentations and aspersions lying down. They should assert themselves; they should put upon foot a campaign of education and instruction for a clearing of the air, so that all over our broad land every 
American may come to respect every other American in whatever business he may be engaged; so that American citizenship shall be forever for the American citizen a title of respect and regard and brotherly affection. We ought to put an end to the condition in which a number of the people in our country feel no regret at the disasters of the people of other parts of the country. It is not an easy task, for this is a tremendous country. But if the men who elected McKinley will rise to the same standard of courage and determination that prevailed in 1896 and 1900, the task can be accomplished.

We have had missionaries of reform, missionaries of new theories, missionaries of every kind and character, except missionaries of good understanding. The business men of America should undertake their mission to make themselves understood by the people of America.

There is one other thing I want to say, and that is that all this regulation, and inspection, and inquiry into the affairs of the business man, present a danger that can be met in only one way. There is a tendency for the railroads to be afraid of the Interstate Commerce Commission, and for the banks to be afraid of the Central Reserve Board and the Comptroller of Currency, and for the express companies to be afraid of the Postmaster-General, and for the industrial establishments to be afraid of the new Trade Commission, and for the manufacturers of everything that comes under the Pure Food law to be afraid of the Department of Agriculture. It is a critical question for the people of the United States, whether that fear is going to control. For if it does, the power will be abused. There is only one way to meet that kind of power, and that is with courage.

What happens today or tomorrow is of little consequence. The tendencies of a nation are all that count. If we permit 
by cowardice or timidity; by cringing before official power if we permit a great body of bureaucracy to establish itself in contrcl over the affairs of our daily lives, the most vital possession of a free people will be destroyed; that is, the independence of individual character.

I grieve to see business halting, to see men out of work, to see honest people deprived of their income, to see the pains of contracting expenditure in the household, to see the unemployed on the street; but all of that is nothing compared with the danger that the people of the United States shall become subscrvient to power; all that is nothing compared with the danger that we lose all independence of individual character which has been built up through all the thousands of years of growth of Anglo-Saxon freedom. If we maintain that, nothing can prevail against us. If we lose it, we are slaves to the first conqueror. The subject is too high and too great for politics. I would not venture to treat it as a political question, for it goes to the very basis of the future of our beloved country.

It seems now that it is the important mission of the Republican party to reassert the individual independence, the individual rights, the individual integrity of the people of the United States. We are not justly subjects of suspicion. We are not justly subjects of condemnation. We are citizens of these great states, of these busy communitics of industry. We are honest, free, true Americans, and we must not and we will not live in an atmosphere of suspicion and distrust. We will not be governed by men who look upon us as unfit to participate in government.

The mission of this Union League is not ended. Not only is eternal vigilance the price of liberty; eternal struggle is the price of liberty. You have again to strike with the weapons of your intelligence and your courage upon the battlefields of 
public discussion, of public education and instruction; to strike and yet again to strike with all your power for the perpetuity of the Union, for the continuance of freedom, for the sure foundations of justice, for the memory of the great man who gave you birth as an organization. In your efforts you have my prayers, and always my grateful and affectionate remembrance. 


\section{THE PRESERVATION OF AMERICAN IDEALS}

ADDRESS AT A DINNER OF THE UNION LEAGUE CLUB, CHICAGO ILLINOIS, IN COMMEMORATION OF THE BIRTHDAY

OF WASHINGTON, FEBRUARY 22, 1904

FTER engaging your attention for more than an hour
this afternoon, ${ }^{1}$ it seems to me that I ought this evening to do nothing more than acknowledge the courtesy and the kindness which I knew I should receive at your hands, and which have exceeded my anticipations tenfold, and with but few formal words to take my seat. I have not meant, and I do not mean, to make a speech; but I cannot find it in my mind to refrain from saying a few words to you as I would if but a half-dozen of us were sitting around the club table, a few words about the things that account for the existence of this club, that account for my being here; a few words about the real significance, the underlying meaning of our presence here together tonight. Why are we joined in a common purpose? What are you to each other aside from your business associations? What are you to me and I to you, apart from a few personal and dear friends whom $I$ have here? Of course, it is because we are Americans; we are patriotic citizens; we love our country. But what does that mean? Is it real ? Is it something really a moving power in our lives, or is it perfunctory - something on the surface? I think it is worth while for us occasionally to put that question to ourselves; worth while for us now and then to bring home to ourselves the real meaning of the meetings we attend,

1 See address on “ The Ethics of the Panama Question," pp. 175-206 in Addresses on International Subjects, Harvard University Press, 1916. 
of the things we say and the sentiments we applaud; the real meaning of the patriotic expressions that have come with such eloquence from the learned judge ${ }^{1}$ who has stepped down from the bench to speak to us tonight; and to consider how far we, each one of us, are carrying into our daily lives the obligation that is correlative to these expressions and to these sentiments.

It has been my fortune for the last few years to study very closely the methods and the fortunes of many republics, of many peoples who have been living under laws framed with the same apparent and ostensible purpose as our own laws; some people living under constitutions framed upon the model of our own; and to see misrule, lack of confidence, stagnation of all material enterprise, and lack of progress in spiritual things as well as material things; to study the reasons why those peoples fail to realize the blessings that we have enjoyed. The prosperity that we have does not come of itself. The enormous increase of wealth which has made possible the great things done by our country in our lifetime, has not come of itself. These things have come because we have had a pecple who were willing to submit themselves to the control of law; a people who, whatever were their individual interests at the time, whatever were the motives that actuated them at the time, whatever they were interested in at the time, have under it all held up consciously or unconsciously the rule of law, the dominion of justice, the interests of human liberty, the open pathway of individual opportunity as superior to all things else. It has been because the great body of American people have held close to the principles established and illustrated and enforced by the man whom we celebrate today, that we are great and prosperous and powerful in the world. And it has been because a great multitude of men in America have individually and

I Emory Speir, of Georgia. 
personally promoted those principles, and still hold dearer than our own individual money-making and propertyaccumulating, and pleasure-loving instincts, the principles of liberty and justice, that we are the great people that we are.

I said these things do not come of themselves, and they do not continue of themselves. Our prosperity depends upon our continuing the principles that underlie it. Each one of us (though he may not attain to fame and distinction and power) is contributing his share towards the prosperity of today. And more than that, each one of us is responsible for the continuance of this government of law and liberty which we hope to hand down to our children and our children's children; and it is because of the conscious or unconscious comradeship and fellowship in the promotion of the rule of justice and liberty and law, of freedom upon earth, that we are here good friends together tonight. I am just old enough to remember as a boy in the days before the Civil War how the speeches of our Fourth of July orators rang false, and the talk about the flag and the spreading of the eagle was laughed at and derided until the day came when the flag, the emblem of American sovereignty, acquired a new meaning, and to the faces that laughed came serious and deep determination to maintain the government that meant so much. The days may come again when those emblems of sovereignty will mean little. Be it our task to see that those days are far distant; not by services which gain public applause, - that means little, it is of no worth when the end comes; but by each man's doing his part to perpetuate institutions that give us what we have and make us what we are. And in this great country which received between the census of 1850 and the census of 1900 over $17,000,000$ of emigrants from the other side of the Atlantic, over 17,000,000 of men who knew little or nothing of the meaning of American freedom and American law; in this great country, so many millions of whose 
inhabitants are far removed from the centers of thought and influence, the active, earnest effort of every true American who loves his country, who wishes for his children and his children's children the liberty and justice and opportunity he has enjoyed, is due from the beginning to the end of his life.

Within the last few days the world has been startled to admiration by the wonderful dash of the Japanese torpedo fleet. Two lessons we may learn from that. One is that confidence in mere bigness, confidence in the power of numbers and extent of territory, confidence in enormous wealth and old traditions, is ill placed when in the swiftly changing affairs of man a strong and vigorous assailant attacks the citadel which seemed secure. And the other is that the supreme possession of a country is the devotion of its sons. The reason why the little Japanese torpedo boats were able to destroy the power of great Russia on the sea, was that the Japanese hold the love of country, the ideal of the State, to a degree that has never been equalled since the days when Rome conquered the world. I remember well when all the world was watching the fate of the beleaguered legations in Peking, when the rescue from the crowding millions of China who had gathered about them seemed hopeless, a little band inadequate in numbers, pressing toward the capital of China, met the strong defenses of Tien-tsin; and when the little force of English and Japanese and Americans assailed that city, a little Japanese swam the moat and placed a mine against the gate and cheerfully blew it up - blew up the gate and blew himself into that heaven where the Japanese go. He went to his death, not with desperation, not merely with stern determination and willingness to sacrifice his life for his country, but he went gladly and joyously, happy if by his poor, single life he could advance the fortunes of his beloved Japan. That is the kind of patriotism that makes nations great, and it was that spirit that in a day destroyed 
the sea power of proud Russia. In all our material wealth, in all the selfishness and luxury of these modern days, be it our work to promote among the people of America that spirit of patriotism, the love of country which holds gold as nothing for the country's sake.

Some one did me the honor not long ago to speak of me as an optimist. I hope I am. I deem pessimism little short of treason. An optimist ? Yes. Because I believe in my country. It is not the incidents of life that are significant. In all the history of this imperfect and erring world there will be unfortunate, sad, and deplorable incidents. Men will go wrong. Love of gain, ambition, will turn aside public servants from their duty. It is not the incidents of life, it is the tendencies of life that we are to regard. How sets the current? Are we moving toward the goal of high ideals? Are we sinking back from them? That is the important question. The play of the waves tells little. The breaking of successive rolling breakers upon the shore tells us nothing of whether the tide is rising or falling. No matter which way the wave is rolling. Does the tide, the great tide of public morality, the great tide of public conscience, set toward our high ideals? And, marking the course of human affairs on this side of the Atlantic, not comparing what we are and what we do with some ideal standard of perfection, but comparing them with what we were and what we have done in the past, we are to gather the answer to the supreme question - comparing weak and imperfect men of today with weak and imperfect men of the century past.

If you will study our history and the lives of our great men, if you will read the records of the first Congress and the first Administration, you will find that there has been steady and uninterrupted progress along the upward pathway of American ideals. You will find that the newspapers of today, even the yellow journals, bad as they are, are not so bad as those 
that maligned Washington. You will find that the evils in public life, which are the objects of criticism and of abhorrence by the good people of America today, are the things which were passed without comment a half-century ago; and the things which were the objects of criticism and abhorrence a half-century ago were the things which passed without comment a half-century before that. The very things which we criticise, the very denunciations of public life today, are evidences of an awakened conscience and advanced morality, because we are criticising the things that but a few years since were not considered reprehensible, or, if they were, did not rise to the dignity of public attention.

I believe that there never has been a time when the public morality of America was purer or better than it is today; that there never has been a time when the conscience of America has been more sensitive in the rules which it has applied to the conduct of public men; that there never has been a time when public servants responded to a higher standard of obligation in their representation of the people both in executive and in legislative life than today. The tendency is rising; the tide sets in the right direction. And how great is the prospect. How noble and elevating are the possibilities of the future. Going through our period of isolation, passing beyond the time of selfishness where we were making our government for ourselves and thinking only of our own interests, there is opening before us the vista of missionary life. I have always thought that there was in the first French Republic an element of nobility never before equalled in human history. Misguided as they often were, untrained as they were in the application of the good and noble principles which they professed, still the men of the first French Republic believed in the principles of liberty, equality, and fraternity, and they were filled with a noble enthusiasm to carry those principles throughout the earth, 
as the old missionaries carried the cross through heathen lands. If we believe what we say; if we believe that the free institutions under which we live are adapted to lift up the masses of mankind out of the hard and degraded conditions under which they have lived in all human history; if we believe that the liberty and justice that prevail under this flag of ours are competent to bless mankind and bring in a day of loftier and happier life for all the world, there opens before us now the opportunity to testify to our belief.

One step we have made in teaching Cuba how to govern herself and starting her under her single star, that represents the aspirations and the struggles of so many a year of sacrifice and of danger. Another step we are making now in trying to train the people of the Philippine Islands in the first lessons of ordered liberty and to teach them how to govern themselves with justice and respect for law. Another lies before us: To show in the Isthmus, to the people of Central and South America, the true conception of liberty. Not the liberty under which each man is to grasp all he can of government and government revenues. Not the liberty of constant rebellion and revolution, but the liberty of order and law, the liberty of individual opportunity and regulated power. I believe that the events which will culminate tomorrow in the ratification of the treaty giving us the right to construct the canal across the Isthmus will result in setting up for the people of South America a standard of good government, a respect for law, for the practical application of the principles of liberty and justice, of which they have had no knowledge before; and that the American people will carry to the people of all those southern countries blessings which will come back to us a thousand fold in our own happiness and our own prosperity.

And for all this, it is not the success of today's speculation, it is not the building of more palaces and more great public 
buildings, it is not the accumulation of power, it is not honor and glory among foreign nations; it is the preservation among the people of the United States of the ideals that have made us what we are. All that has made our prosperity is the confidence, the security, the safety, of American institutions. All that will make the prosperity of our children, all that will make possible the continued progress of this greatest instrumentality since the dawn of history for human good, is the preservation of the ideals of individual liberty and equal justice. No man can fail to do his part toward preserving these among his fellow-men in America and not be false to his children, false to his own higher interests, false to his country. And sharing in the hope of promoting these American ideals, I am here your friend, and your friend so long as life lasts. 


\section{THE MONROE DOCTRINE}

\section{ADDRESS AT THE NINETY-NINTH ANNUAL BANQUET OF THE NEW ENGLAND SOCIETY OF NEW YORK \\ DECEMBER $2 \&, 1904$}

Those who desire the complete exposition of Mr. Root's views on the Monroe Doctrine should read also his eighth presidential address before the American Society of International Law, April 22, 1914 (Addresses on International Subjects, pp. 105-123. Harvard University Press, 1916.)

UDGE HOWLAND has well said that our forefathers are not to be judged by the standards of today. It is equally true that their descendants are not to be judged by the standards of their day. Our opportunities, the scope and power of our American life today, afford no recourse or refuge from responsibility in imitation of the practices to which they were obliged to resort for the preservation of life and the state, when, surrounded by hostile foes, contending against harsh conditions, they led their life of severe and relentless strife. Our opportunities are world-wide; they are the opportunities of peace and justice, of civilization and brotherhood for all mankind; and the principles which, under their narrow and harsh conditions, made the Puritans great, can make us great, not by doing as they did, but by living in the spirit in which they wrought; not by achieving the results which they achieved, in the way in which they achieved them, but by doing the work that lies at our hands in the way pointed out by the conditions which surround us. We have had within a few days in this city a great meeting of the advocates of peace, a meeting designed to promote the principles of arbitration among nations, and with the purpose of that meeting, with the things that were said and the results 
which it sought to accomplish, I heartily agree, and I believe all of you agree. But after all, the true way to accomplish peace among men is to promote justice among men, and good understanding, for all wars come from misunderstandings or injustice, a failure of some one to do his duty to his fellowmen; and if the nations of the earth will seek to realize their obligations to each other, to do their duty, with consideration, with regard for the rights of others, the reign of peace will be here. The obligation that rests upon us is the obligation to understand not only our own rights but our own duties. In a republic the great issues of peace and war are determined not by presidents and congresses, not by officers in any station, but by the people themselves; and the first necessary element of enduring peace is an adequate and clear understanding, by the people who make war or preserve peace, of their rights and of those obligations which are always correlative to rights.

The peaceful, patient, and long-suffering President McKinley sought with all his earnestness and his wonderful skill to avoid war with Spain. But the gathering indignation of the people compelled war. Ten years ago we were brought to the verge of a war with Great Britain by a position taken on the part of the United States, which, with almost any other power in Christendom, would have produced immediate war, and the people were ready for it, although we were wholly unprepared. But a few weeks ago the English people were eager for a war over the Doggers Bank incident, the firing on the fishing boats by the Russian fleet; and the terrible results of a conflict between Great Britain and Russia were averted only by the skillful statesmanship of Mr. Balfour and Lord Lansdowne. The most essential thing for peace among men is that the people who make peace or make war shall understand, shall have reflected upon, the questions which give rise to peace or war. 
The only relation which carries the possibilities of war for this country is that created by the adherence of the American people to the doctrine which is called the Monroe Doctrine. Twenty years ago next year Mr. Samuel J. Tilden, that wise and astute statesman, wrote a letter, since famous, which was the basis of our entire system of coast defense, upon which we have already expended over sixty millions of dollars, and are expending another sixty millions. And the fundamental proposition upon which he based the necessity of that expenditure was the danger of war arising from the assertion of the Monroe Doctrine. The imminent danger of war over the Venezuela matter ten years ago arose upon the assertion of the Monroe Doctrine. As the nations of the earth grow greater, as by the very reign of peace, by the termination of internal discord, by the doing away with famine and with pestilence, by the advance of hygiene and medical science, by the advance of means of communication, the advance of charity, of good administration, the Malthusian checks to population disappear, the surplus energies of the nations are sending their population out to the whole unpeopled surface of the earth. Each nation is jostling against the other, and every nation is preparing to maintain and defend its rights against all who infringe upon them in the closer contact and conflict of modern life.

The Monroe Doctrine is an assertion on the part of America:

1. That no part of the American continent is justly subject to colonization by any European power.

2. That the interposition of any foreign power for the purpose of oppressing or controlling in any other manner the destiny of any American people will be regarded as an unfriendly act to the United States.

3. That any attempt by a European nation to extend its system to the American continent will be regarded as danger- 
ous to the peace and safety of the United States. And to that was added, in 1845, by President Polk, the further item that no future European colony or dominion should with our consent be planted or established upon our continent. And that last extension applies to any voluntary transfer of the territory of an American country to any European power.

The questions which are liable to arise under that assertion of American right will not come by a frontal attack; by any broad and unqualified denial of our right to maintain that doctrine as a rule of national safety. In the long process of years I think we can safely say that there has been gradually accumulated such a weight of assent upon the part of foreign nations to our rights to assert and maintain this doctrine that it is no longer open to question.

But the way in which cause of war may arise will be, if at all, by the conflict of rights - the existence of rights on the part of foreign powers against American republics, and the result of the enforcement of those rights of foreign powers against the American republics coming in conflict with this doctrine which we assert for our own safety and preservation. All sovereignty in this world is held upon the condition of performing the duties of sovereignty. In the parliament of man the rights of the weakest state are recognized; the right of the sovereign ruler or the sovereign people to be protected against aggression is recognized and protected by the common influence of mankind. But that right is held upon condition that the sovereign ruler or the sovereign people performs the duties of sovereignty; that the citizens of other powers are protected within the territory; that the rules of international law are observed; that national obligations are faithfully kept. And while we assert that we are entitled to say that no foreign power shall undertake to control an American republic, that no foreign power shall take possession with or without the will of an American people of their territory, 
that assertion is justified only upon the same condition. We do not undertake to say that the republics of Central and South America are to be relieved from their international obligations. We do not undertake to say that the Powers of Europe shall not enforce their rights against these members of the sisterhood of nations. It is only when the enforcement of those rights comes to the point of taking possession of the territory of any American people that we say that is inconsistent with the peace and safety of the United States; and we cannot say it with justice unless we also say that the American republics are themselves to be just.

It is always possible that redress of injury, that punishment for wrong, may lead to the occupation of territory. Egypt today is held practically under the sway of England, because Egypt was unable to pay her debts. Greece today is under the control of a government set up by the Powers, taken away from the control of her old sovereign, Turkey, because Turkey was unable or unwilling to compel Greece to perform her international duties. And if we are to maintain this doctrine, which is vital to our national life and safety, at the same time when we say to the other Powers of the world, "You shall not push your remedies for wrong against these republics to the point of occupying their territory", we are bound to say that whenever the wrong cannot be otherwise redressed we ourselves will see that it is redressed.

That is the doctrine of the quotation from the President's letter which you find upon our program this evening underneath the toast to which I speak. That statement of the American position made by the American President was not an advance, an aggression, a statement of a purpose beyond the purposes declared before by American statesmen. It was a definition and limitation of American purposes with reference to what had already been said by American states- 
men. The most extreme declaration of the Monroe Doctrine which I know of was made by Mr. Olney in his letter at the time of the Venezuela boundary question in 1895, when he said: "Today the United States is practically sovereign on this continent, and its fiat is law upon the subject to which it confines its interposition." The tremendous scope and meaning of those words for the weak little republics of Central and South America cannot be exaggerated. "The United States is sovereign today upon this continent, and its fiat is law!"

The declaration of the President of the United States in the letter to the Cuban dinner which is quoted upon this program, and in his last message, is a disclaimer of all that we ought not to arrogate to ourselves in that broad and somewhat rhetorical statement of Mr. Olney. It is a declaration that we arrogate to ourselves, not sovereignty over the American continent, but only the right to protect; that what we will not permit the great Power of Europe to do on this continent we will not permit any American republic to make it necessary for the great Powers of Europe to do. The obligation of civilization to see that right and justice are done by these republics which we protect with our strong arm, against oppression by other powers of the world is an obligation that always must go with the right that we assert. And when in days to come vital questions which may make for peace or for war arise let us be sure that the American people who will determine on peace or war understand, have considered, have discussed, not merely the right, but the duty that goes with the right. Above all things let us be just. Let us do equity when we come into the great court of civilization. Let us see that we ourselves and those whom we protect for our safety are just, and our cause will be just. Then if injustice be done to them or to us we will remember those noble words of President Cleveland, when, in writing 
upon the same Venezuelan question, he said: " There is no calamity which a great nation can invite which equals that which follows a supine submission to wrong and injustice and the consequent loss of national respect and honor, beneath which are shielded and defended a people's safety and greatness." Then in the spirit of our Pilgrim fathers, the corner stone of whose religion was justice, we will maintain our right and the right of all who depend upon us for protection; maintain it in the name of justice and liberty; maintain it with a strong arm, if need be, and maintain it ever. 



\section{THE CAUSES OF WAR}

ADDRESS AT A DINNER OF THE NEW YORK PEACE SOCIETY IN RECOGNITION OF THE SERVICES OF THE SECRETARY

OF STATE TO INTERNATIONAL PEACE

FEBRUARY 26, 1909

$T^{T}$ seems to me that the Peace Society has gathered here all 1 the evidences, all the proofs, has made the demonstration, of what it is worth to preserve peace; the faces of the dear old friends of a life-time, the children of many a friend who has passed away during my absence from New York, all this that I see about me, is what makes it worth while that peace shall be preserved - the charm and grace of life, the joy of living, the virtues, the beauty, the nobility, preserved, defended, and continued by this modern civilization which substitutes peace for war. We have passed in the development of modern society far from those old days when men fought for the mere joy of fighting. Except here and there an individual and here and there a half-savage community, no one now makes war for the love of war.

So long as selfishness and greed and the willingness and the brutality to do injustice continue in this world, we must have the policeman; and the international policem an whose presence makes the use of his club unnecessary, is the army and the navy.

But the work of peace-loving men and women, the work of all those who love home, who desire that mankind shall be enlarged in intelligence and in moral vision, of all those who desire to see science and art and the graces of life and sweet charity and the love of mankind for one another continue and grow among men, their work is to aid, not by great 
demonstration, but by that quiet, that resistless influence, which among great bodies of men makes up the tendency of mankind, and in the long process of the years moves men from savagery and brutality to peace and brotherhood. It rests with the army and the navy to make aggression and injustice unprofitable and unattractive. It rests with you and with me to exercise the powers that God has already placed in our hands. It rests with every man in the exercise of his duties, political and social, to move the conceptions of an honorable life away from the old ideas of savagery towards the new ideas of civilization, of humanity, that in their progress gradually approach the supreme idea of Christianity.

Peace can never be except as it is founded upon justice. And it rests with us in our own country to see to it that the idea of justice prevails, and prevails against the declamation of the demagogue, against the interested exhortation of the politician, against the hot temper of the thoughtless and of the inconsiderate. If we would have peace, it is not enough to cry "Peace! Peace!" It is essential that we should promote and insist upon the willingness of our country to do justice to all countries of the earth. In the exercise of those duties in which the ambassadors of Great Britain, of Brazil, and of Japan have played so great a part with us in the last few years in Washington, the great obstacles to the doing of things which make for peace have been not the wish of the diplomatist, not the policy of the Government, but the inconsiderate and thoughtless unwillingness of the great body of the people of the respective countries to stand behind the man who was willing for the sake of peace and justice, to make fair concessions.

There is a peculiar situation created when a diplomatic question arises between two countries. It is the duty of the diplomatic representative to argue each the cause of his own country; he cannot turn his back upon an opponent in that 
friendly contest and state to his countrymen the weakness of his own position and the strength of the other side's position, and it is one of the great difficulties of peace-making and peace-keeping that the orators, the politicians, the stump speakers, aye, often the clergymen of each country, press and insist upon the extreme view of their own country, and impress upon the minds of the great masses of people who have not studied the question, the idea that all right is upon one side and all wrong upon the other side.

If you would help to make and keep peace, stand behind the men who are in the responsible positions of government, ready to recognize the fact that there is some right on the other side.

War comes today as the result of one of three causes; either actual or threatened wrong by one country to another; or suspicion by one country that another intends to do it wrong, and upon that suspicion, instinct leads the country that suspects the attack, to attack first; or, from bitterness of feeling, dependent in no degree whatever upon substantial questions of difference; and that bitterness of feeling leads to suspicion, and suspicion in the minds of those who suspect and who entertain the bitter feeling, is justification for war. It is their justification to themselves. The least of these three causes of war is actual injustice. There are today acts of injustice being perpetrated by one country upon another, there are several situations in the world today, where gross injustice is being done. I will not mention them, because it would do more harm than it would good, but they are few in number. By far the greatest cause of war is that suspicion of injustice, threatened and intended, which comes from exasperated feeling. Now feeling, the feeling which makes one nation willing to go to war with another, makes real causes of difference of no consequence. If the people of two countries want to fight, they will find an excuse - a pretext - find 
what seems to them sufficient cause, in anything. Questions which can be disposed of without the slightest difficulty between countries really friendly, are insoluble between countries really unfriendly. And the feeling between the peoples of different countries is the product of the acts and the words of the peoples of the countries themselves, not of their governments. Insult, contemptuous treatment, bad manners, arrogant and provincial assertion of superiority are the chief causes of war today.

And in this country of ours, we are not free from being guilty of all those great causes of war. The gentlemen who introduced into the legislatures of California, Montana, and Nevada, the legislation regarding the treatment of the Japanese in those states, doubtless had no conception of the fact that they were offering to that great nation of gentlemen, of soldiers, of scholars and scientists, of statesmen, a nation worthy of challenging and receiving the respect, the honor and the homage of mankind, an insult that would bring on private war in any private relation in our own country. Thank Heaven, the wiser heads and the sounder hearts, instructed and enlightened upon the true nature of the proceedings, prevailed, and overcame the inconsiderate and thoughtless.

There are no two men in this room tonight who eannot bring on private war between themselves by an insult without any cause or reason, and it is so with the nations, for national pride, national sensitiveness, sense of national honor, are more keenly alive to insult than can be the case with any individual. But a few days ago, a member of the House of Representatives, charged upon the chief magistrate of the little republic of Panama, a fraudulent conspiracy with regard to a contract under negotiation by the government of that country regarding the forests of Panama. All Panama was instantly alive with just indignation. This insult was 
felt all the more keenly because we, with our ninety millions and our great navy and army, presented an overwhelming and irresistible force toward a little republic whose sovereignty we are bound, trebly bound, in honor to maintain and respect.

These are the things that make for war and if you would make for peace, you will frown upon them, condemn them, ostracize and punish by all social penalties, the men who are guilty of them, until it is understood and felt that an insult to a friendly foreign power is a disgrace to the insulter, upon a level with the crimes that we denounce and for which the law inflicts disgraceful punishment.

Two-thirds of the suspicion, the dislike, the distrust with which our country was regarded by the people of South America, was the result of the arrogant and contemptuous bearing of Americans, of people of the United States, towards those gentle, polite, sensitive, imaginative, delightful people. Allusion has been made to my visit there, to the generous, magnanimous hospitality that they have inherited from their ancestors of Spain and Portugal, and that opened wide the gateways of their land and their hearts to a message of courtesy and kindly consideration. No questions existed before to be settled, no serious questions have been settled, but the difference between the feeling, the attitude, of the people of Latin America and our republic today from what it was four years ago, is the result of the conspicuous substitution of the treatment that one gentleman owes to another, for the treatment that one blackguard pays to another.

Now this is a subject for you to deal with. The government cannot reach it. Laws cannot control it; public opinion, public sentiment must deal with it, and when public opinion has risen to such height all over the world, that the peoples of every country treat the peoples of every other country with the human kindness that binds home com- 
munities together, you will see an end of war - and not until then.

But it becomes less and less necessary to preach peace. We have not reached ideal perfection yet, far from it; but the way to judge of conditions in this world is not by comparing them with the standard of ideal perfection; it is by comparing the conditions today with the conditions of the past and noting, not what we can do today. If we note that alone, we must be discouraged; if we note that alone, we must be convinced of the desperate selfishness, the injustice, the cruelty of mankind. But if we compare the conditions of today with the conditions of yesterday and the last decade and the last generation, and the last century and centuries before, no one can fail to see that in all those qualities of the human heart which make the difference between cruel and brutal war, and kindly peace, the civilized world is steadily and surely advancing day by day. No one can fail to see that the continuous and unswerving tendency of human development is towards peace and the love of mankind. 


\section{THE EFFECT OF DEMOCRACY ON INTERNATIONAL LAW}

PRESIDENTIAL ADDRESS AT THE ELEVENTH ANNUAL MEETING OF THE AMERICAN SOCIETY OF INTERNATIONAL LAW

WASHINGTON, D. C., APRIL 26, 1917

$\mathrm{T}$ trying to estimate the future possibilities of international 1 law, and to form any useful opinion as to the methods by which the law can be made more binding upon international conduct, serious difficulties are presented in the unknown quantities introduced by the great war, which is steadily drawing into its circle the entire civilized world. Hitherto, we have been unable to form any real judgment as to which of the two warring groups of nations will succeed in the end. Our expectations and beliefs upon that question have been the products of our sympathies and our hopes, and of an optimism for which it is now happily more easy to find just grounds than ever before.

Nor have we been able to measure the effects of the war upon national character, and the probable results in national modes of thought and conduct. A just estimate of such forces is not easy. The modern era of nationalities has been marked by three great convulsions which turned the minds of all civilized men towards peace, and led them to seek means to make peace secure.

The Thirty Years' War produced the Peace of Westphalia and the system of independent nationalities in Europe, and it produced Grotius and the science of international law; and practically every power in Europe except the Ottoman Empire was a party to the agreement to maintain the system 
thus established. Yet, the century which followed exhibited the most cynical and universal disregard for the law, and for the treaty, and for all treaties.

The Napoleonic wars produced the Treaty of Vienna and the Holy Alliance. That sincere but misguided effort sought to fix the limits and regulate the conduct of the nations of Europe in accordance with the principles which the treatymaking powers then believed to be in keeping with right and justice, and to be effective for the permanent peaceful organization of the community of nations, and it sought to maintain the status quo by the establishment of a league to enforce peace in accordance with their conception. Yet, the arrangements were conceived by minds imbued with the spirit of the past, and became of no effect when tested by the changes wrought by the spirit of the future. The old bottles were filled with new wine and could not contain it; so the scheme came to naught.

Both of these efforts to secure permanent peace under the rule of law failed because the unappreciated forces working for change and growth became stronger than the gradually decreasing restraint of agreements to maintain a fixed and immutable relation of territory and opportunities among the nations. It is reasonable to infer that a similar result must follow any attempt to base a system of international law upon definite and rigid limitations devised to meet the expediency of the moment. The law of life is growth, and no generation can prevent the growth of future generations by fixing in accordance with its ideas the specific conditions under which they are to live. As we look back, we see a multitude of ancient wrongs protected by the law of nations, naturally enough, because the law has been made by powers in possession. We have a vague impression that international wrongs are cured by time. That is not always so. There is no international statute of limitations. Time alone 
cures no wrong. The people to whom wrong is done may be destroyed, as the Turks are destroying the Armenians; or the wronged people may be reconciled to the new conditions like the Saxons in England; but, for example, the unforgiven wrong of the Turk in Europe, and the unforgiven wrong of the partition of Poland, are always forces working against the law that protects them. The maintenance or the redress of such wrongs is merely a question of relative power. The rise in power of Christian Europe, and the decadence of the Ottoman Empire, make inevitable the complete refluence of the tide which once reached the walls of Vienna, and even to the valley of the Loire. No human laws or conventions could bind the forces which work through centuries to achieve such results. The futility of efforts to control such movements of mankind by the short-sighted policies of the passing day cannot be better illustrated than by the misplaced energy and sacrifice of the Crimean War and the fatuous ingenuity of the Congress of Berlin which sought to bolster up and preserve the sovereignty of the Turk.

As we consider how it may be possible to reëstablish the law of nations upon a durable basis, we must realize that past experience indicates that no system of law which depends upon the physical partition of the earth dictated by the expediency of the time, no law which must be broken in order that living wrongs shall be redressed, or in order that the new ideas of the future may find room for growth, can be permanent.

We should therefore inquire whether the political and social conditions to which we may reasonably look forward after the war, the forces that are to move mankind, the trend of development, will be such as to enable us in our day to escape the errors of our predecessors, and to establish upon some basis of principle a system of international law which can be maintained and enforced. 
The greatest change in the conditions of national life during the past century has been in the advance and spread of democratic government, and the correlative decrease in the extent and power of autocratic and dynastic governments. It is impossible to regard the advance of democracy as being merely local or temporary. It has been the result of longcontinued and persistent progress varying in different countries according to the character of the people, and the nature of the obstacles to be overcome, but, in its nature, essentially the same in all countries.

England in her steady-going undemonstrative way has moved along from government by a king claiming divine right to a Commons representing popular right through the revolution of 1688 , which established the nation's right to choose its king, through that civil war over the rights of British subjects known as the American Revolution, through chartism and Catholic emancipation, the Reform Bill of 1832, the franchise extension of 1867 , the abandonment of the king's veto power, and the establishment of the Commons' right to pass bills over the rejection of the House of Lords.

France in her own different way with much action and reaction travelled towards the same goal through the States General and the Constituent Assembly, through the Reign of Terror, and her amazing defense of the First Republic against all Europe, through the heroic surgery of Napoleon's career, the Bourbon restoration, the assertion of her right to choose her own king in 1830, and the assertion of her right to dispense with a king in 1848, the plebiscite and the Second Empire, the Commune and the Third Republic, which has grown in stability and capacity for popular government until the steadiness and self-control and noble devotion of the French people under suffering and sacrifice have come to be one of the amazing revelations of these terrible years. 
Italy struggling out of the control of a multitude of petty tyrants sustained by foreign influence, established her newlywon unity and independence upon the basis of representative parliamentary government.

Spain has regained and strengthened the constitution of which Ferdinand VII and the Holy Alliance deprived her.

Throughout the greater part of the world constitutions have become the order of the day. Switzerland, Belgium, Holland, Portugal, all Scandinavia, all Latin America, have established their governments upon constitutional bases.

Japan, emerging from her military feudalism, makes her entry into the conmunity of civilized nations under a constitutional government. China, throwing off the domination of the Manchu, is striving to accustom her long-suffering and submissive millions to the idea of constitutional right.

The great self-governing British Dominions bound to the mother-country only by ties of tradition and sentiment have shown that free democracies can respond to moral forces with a splendid power of loyalty that no coercion could inspire. And now, Russia, extirpating the government which has been for modern times the typical illustration of autocracy, is engaged in establishing the new self-control of that vast empire upon the basis of universal suffrage and republican institutions.

The political conception of control from above by monarchs exercising divine right is not merely disputed by philosophers and reformers; it has faded and grown dim in the minds of the millions of men in the civilized nations, and in its place has spread throughout the world the political conception of constitutional government exercising control by authority of the peoples who are governed.

The persistence and extent of this change in the political and social conditions of national life forbid the idea that it is the child of individual minds or local provocations or tem- 
porary causes, and distinguish it as one of those great and fundamental movements of the human mind which no power can control, and which run their course inevitably to the end in an unknown future. The existence and assured continuance of this process of development of democracy is the great fact forecasting the future conditions under which the effort to reinstate the law of nations is to be made.

What is to be the effect of this change in conditions upon the possibility of making international law relatively permanent? In considering this question, some facts can be clearly perceived.

The substitution of a democratic for an autocratic régime removes the chief force which in the past has led nations to break over and destroy the limitations of law; that is, the prosecution of dynastic policies. Such policies in general have in view the increase of territory, of dominion, of power, for the ruler and the military class or aristocracy which surrounds the ruler and supports his throne. The benefit of the people who are ruled is only incidentally - if at all involved. If we turn back to the causes which destroyed the peace of the world under the dispositions made by the Treaty of Westphalia, the mind naturally rests on the War of the Spanish Succession which drenched Europe in blood through the first decade of the eighteenth century, and ended in the Treaty of Utrecht only when Louis XIV was reduced to exhaustion. What was that about? Nothing more or less than the question what royal house should have its power increased by a marriage that would ultimately enable it to control the territory and wield the power of Spain for its own aggrandizement. The interests of the people of Spain or the people of France or of any other country furnished no part of the motive power. What caused the War of the Austrian Succession a generation later, when Frederick (called "The Great") marched his army into Silesia to wrest that province 
from the feeble hands of young Maria Theresa in flagrant violation of his solemn promise to protect her title under the covenants of the pragmatic sanction, and when the nations of Europe gathered like buzzards about one dying, eager to share in the dismemberment of the possessions of the House of Austria? It was the desire of royal princes to increase their power and glory regardless of law and justice, and the welfare of peoples, and, incidentally, a desire by some states to prevent that increase, lest the same rule of spoliation might more readily be applied to them.

Underlying the whole age-long struggle to maintain the balance of power in Europe has been the assumption that increased power would be used for aggression and to secure further increase of power by the conquest of territory and the subjection of its inhabitants; and the common experience of mankind under the autocratic system of government by divine right has justified the assumption. It was a perfect understanding of this characteristic of autocratic government that inspired the words of President Monroe's famous declaration: "We should consider any attempt on their part (the European powers) to extend their system to any portion of this hemisphere as dangerous to our peace and safety."

Against the deep and settled purpose of a ruling family or a ruling aristocratic class to enlarge its power, continuing from generation to generation, usually concealed until the favorable moment for action comes, always justified or excused by specious pretexts, the advocates of peace, or justice, or humanity, or law, are helpless. All other causes of war can be reached. International misunderstandings can be explained away. Dislikes and suspicions can be dissipated by intercourse, and better knowledge, and courtesy, and kindness. Considerate justice can prevent real causes of war. Rules of action to prevent controversy may be agreed upon by diplo- 
macy and conferences and congresses. Honest differences as to national rights and duties may be settled by arbitration, or judicial decision; but against a deep and persistent purpose by the rulers of a great nation to take away the territory of others, or to reduce others to subjection for their own aggrandizement, all these expedients are of no avail. The Congresses of Westphalia, of Vienna, of Berlin, and a multitude of others less conspicuous, have sought to curb the evil through setting limits upon power by treaty. They have all failed. The Peace Conferences at The Hague have sought to diminish the evil by universal agreement upon rules of action. The rules and the treaties have become "scraps of paper".

The progress of democracy, however, is dealing with the problem by destroying the type of government which has shown itself incapable of maintaining respect for law and justice and resisting the temptation of ambition; and by substituting a new form of government, which in its nature is incapable of proceeding by the same methods, and necessarily responds to different motives and pursues different objects from the old autocratic offenders. Only when that task has been substantially accomplished will the advocates of law among nations be free from the inheritance of former failure. There will then be a new field open for a new trial, doubtless full of difficulties of its own, but of fair hope and possibilities of success.

Self-governing democracies are indeed liable to commit great wrongs. The peoples who govern themselves frequently misunderstand their international rights, and ignore their international duties. They are often swayed by prejudice, and blinded by passion. They are swift to decide in their own favor the most difficult questions upon which they are totally ignorant. They are apt to applaud the jingo politician who courts popularity by public insult to a friendly 
people, and to condemn the statesman who modifies extreme demands through the concessions required by just consideration for the rights of others. All these faults, however, are open and known to the whole world. The opinions and motives from which they proceed, the real causes of error, can be reached by reason, by appeal to better instincts, by public discussion, by the ascertainment and dissemination of the true facts.

There are some necessary features of democratic selfgovernment which tend towards the progressive reduction of tendencies to international wrong-doing. One is that democracies are absolutely dependent for their existence upon the preservation of law. Autocracies can give commands and enforce them. Rules of action are a convenience, not a necessity for them. On the other hand, the only atmosphere in which a democracy can live between the danger of autocracy on one side and the danger of anarchy on the other is the atmosphere of law. Respect for law is the essential condition of its existence; and, as in a democracy the law is an expression of the people's own will, self-respect, and personal pride, and patriotism demand its observance. An essential distinction between democracy and autocracy is that while the government of an autocracy is superior to the law, the government of a democracy is subject to the law. The conception of an international law binding upon the governments of the world is therefore natural to the people of a democracy, and any violation of that law which they themselves have joined in prescribing is received with disapproval, if not with resentment. This is well illustrated by the attitude of the people of the separate states of the American Union towards the decisions of the Supreme Court of the United States passing upon the exercise of power by state governments. Physical force has never been used to compel conformity to those decisions. Yet, the democratic people of the United States 
have answered Jefferson's contemptuous remark "John Marshall has made his decision; now let him enforce it." The answer is that it is the will of self-governed democracy to obey the law, which it has itself established, and the decisions of the great tribunal which declares the law controlling state action will be accepted and observed by common consent and enforced by the power of public opinion.

Another necessary feature of democratic government is that the exercise of the power of popular self-government is a continual training of all citizens in the very qualities which are necessary for the maintenance of law between nations. Democratic government cannot be carried on except by a people who acquire the habit of seeking true information about facts, of discussing questions of right and wrong, of interest, and of possible consequences, who have kindly consideration for opposing opinions, and a tolerant attitude towards those who differ. The longer a democracy preserves itself through the exercise of these qualities, the better adapted it is to apply the same methods in the conduct of its international business, and the result is a continually increasing certainty that international law will be observed in a community of democratic nations.

The most important difference, however, between the two forms of government, is that democracies are incapable of holding or executing those sinister policies of ambition which are beyond the reach of argument and the control of law. A democracy cannot hold such policies, because the open and public avowal and discussion which must precede their adoption by a democracy is destructive of them; and it cannot execute such policies because it uniformly lacks the kind of disciplined efficiency necessary to diplomatic and military affirmatives. The settled and continuous policies of a democracy are defensive. Nearly ninety years ago De Tocqueville in his survey On Democracy in America recorded what he 
deemed to be a weakness of our system of government in foreign affairs. He said:

Foreign politics demand scarcely any of those qualities which a democracy possesses, and they require on the contrary the perfect use of almost all those faculties in which it is deficient. Democracy is favorable to the increase of the internal resources of the State; it tends to diffuse a moderate independence; it promotes the growth of public spirit, and fortifies the respect which is entertained for law in all classes of society; and these are advantages which only exercise an indirect influence over the relations which one people bears to another. But a democracy is unable to regulate the details of an important undertaking, to persevere in a design, and to work out its execution in the presence of serious obstacles. It cannot combine its measures with secrecy, and it will not await their consequences with patience. These are qualities which more especially belong to an individual or to an aristocracy, and they are precisely the means by which an individual people attains to a predominant position.

So long as foreign affairs were to continue as they were carried on in his day, De Tocqueville was doubtless right. It is because democracies are not fitted to conduct foreign affairs as they were conducted in De Tocqueville's day that the prevalence of democracy throughout the world makes inevitable a change in the conduct of foreign affairs. Such affairs when conducted by democratic governments must necessarily be marked by the absence of those undertakings and designs, and those measures combined with secrecy, prosecuted with perseverance, for which he declares democracies to be unfit.

This characteristic of popular governments is well illustrated by the hundred years of peace which we are all rather proud of preserving throughout the three thousand miles of boundary between Canada and the United States without fortifications or ships of war or armies. There have been many occasions when the tempers of the men on either side of the line were sorely tried. The disputes regarding the Northeastern Boundary, the Oregon Boundary, the Alaska Boundary, were acute; the affair of the Caroline on the Niagara River, the Fenian raid upon Lake Champlain, the 
enforcement of the fisheries regulations, were exasperating and serious, but upon neither side of the boundary did democracy harbor those sinister designs of aggrandizement and ambition which have characterized the autocratic governments of the world. On neither side was there suspicion of any such designs in the democracy across the border. The purpose of each nation was merely to stand up for its own rights, and so reason has always controlled, and every question has been settled by fair agreement, or by arbitral decision; and, finally, for the past eight years a permanent International Commission with judicial powers has disposed of the controversies arising between the citizens of the two countries along the border as unobtrusively and naturally as if the questions arose between citizens of Maryland and Virginia. Such has been the course of events, not because of any great design or far-seeing plan, but because it is the natural working of democratic government.

The incapacity of democracies to maintain policies of aggression may be fairly inferred from the extreme reluctance with which they incur the expense and make the sacrifices necessary for defense. Cherishing no secret designs of aggression themselves, they find it difficult to believe in the existence of such designs on the part of other nations. Only imminent and deadly peril awakens them to activity. It was this obstinate confidence in the peaceable intentions of all mankind which met Lord Roberts (honored, trusted and beloved as he was), when long before the present war he vainly sought to awaken the people of England to the danger that he saw so plainly in Germany's stupendous preparation for conquest. It is well known that when the war came France was almost upon the verge of diminishing her army by a reduction in the years of service. In our own country a great people, virile, fearless, and loyal, have remained indifferent to all the voices crying in the wilderness for prepara- 
tion, because the American people could not be made to believe that anything was going to happen inconsistent with the existence everywhere of those peaceful purposes of which they themselves were conscious.

There is a radical incompatibility between popular selfgovernment and continuous military discipline, for military control is in itself despotic. As compared with military autocracies, the normal condition of democracies is a condition of inferior military efficiency. This invariable characteristic of democracy leaves it no option in its treatment of autocracy. The two kinds of government cannot live permanently side by side. So long as military autocracy continues, democracy is not safe from attacks, which are certain to come some time, and certain to find it unprepared. The conflict is inevitable and universal; and it is à outrance. To be safe, democracy must kill its enemy when it can and where it can. The world cannot be half democratic and half autocratic. It must be all democratic or all Prussian. There can be no compromise. If it is all Prussian, there can be no real international law. If it is all democratic, international law honored and observed may well be expected as a natural development of the principles which make democratic selfgovernment possible.

The democracies of the world are gathered about the last stronghold of autocracy, and engaged in the conflict thrust upon them by dynastic policy pursuing the ambition of rulers under claim of divine right for their own aggrandizement, their own glory, without regard to law, or justice, or faith. The issue today and tomorrow may seem uncertain; but the end is not uncertain. No one knows how soon the end will come, or what dreadful suffering and sacrifice may stand between; but the progress of the great world movement that has doomed autocracy cannot be turned back, or defeated. 
That is the great peace movement. There the millions who have learned under freedom to hope and aspire for better things are paying the price that the peaceful peoples of the earth may live in security under the protection of law based upon all-embracing justice, and supreme in the community of nations. 


\title{
THE SPREAD OF INTERNATIONAL LAW IN THE AMERICAS
}

\author{
ADDRESS AS TOASTMASTER AT A BANQUET OF THE DIVISION \\ OF INTERNATIONAL LAW OF THE CARNEGIE ENDOWMENT FOR \\ INTERNATIONAL PEACE, WASHINGTON, DECEMBER 30, 1915
}

The Second Pan American Scientific Congress, composed of official and unofficial delegates of the twenty-one American republics, met at Washington, December 27 , 1915 - January 8, 1916. Section VI of the congress was devoted to international law, public law, and jurisprudence, and the American Society of International Law, the Political Science Association, and the American Society for the Judicial Settlement of International Disputes, held joint sessions with the members of this section. The American Institute of International Law held its first session in connection with and under the auspices of the congress, and it likewise held a joint meeting with the American Society of International Law, affiliated with it. The American Institute of International Law adopted at this session its declaration of the rights and duties of nations. For further information concerning the origin, the nature, and the services which this scientific body could hope to render, composed as it is of five publicists from each of the American republics, the reader is referred to Mr. Root's address, entitled "The Declaration of the Rights and Duties of Nations of the American Institute of International Law," to be found in the volume of his Addresses on International Subjects, pages 413-426, included in this series.

On December 30, 1915, the Division of International Law of the Carnegie Endowment for International Peace gave a banquet to the delegates attending Section VI of the Second Pan American Scientific Congress, the members of the American Institute of International Law, of the American Society of International Law, of the Political Science Association, and of the American Society for the Judicial Settlement of International Disputes.

In the course of the remarks delivered by Dr. Ernesto Quesada, chairman of the Argentinian delegation and a distinguished jurist and economist of his country, he thus referred to the problems confronting the Americas, to the rôle of the United States in the settlement of these problems, and to its illustrious statesmen in the past and its illustrious statesman of the present day:

We all think, in the Southern Hemisphere, that this is perchance the most solemn and important moment in the life of civilized nations, and that it represents a real turning-point in history. The classical international law, framed alike by facts and doctrine in the ancient nations of Europe, has in effect committed suicide. The present terrible and sad experience shows that it was a sort of compromise, accepted always with the hidden thought that when the ambitions or the interests of those nations should conflict with it, it need not be observed. We, in America, have quite different international problems, and 
our special geographical positions give to these a characteristically continental aspect. The old European international law is bankrupt: the new American international law will step in, in its place, as representing the modern tendencies of civilization, free from the entangling traditions that guide the policy of the nations of Europe.

Therefore, in this very important moment of history, America must hold upright this part of the social sciences and remodel it in order to give it permanent life, independent of the unavoidable fetters of the secular European tradition. This is the noble task that Amcrica must take energetically in its hands, combining the efforts of more than twenty nations. The United States, as the richest and most powerful of them all, as perhaps the most important nation in the whole world, with its hundred millions of citizens and its unbounded resources, must forcefully lead the way. We all think, in both American divisions of the hemisphere, that the pivot of civilization will in the future be this country, and that as a consequence, its statesmen - I mean those of the sort of Hamilton and Webster in the past, and, if you will allow me to express the South American opinion clearly, of Mr. Root in the present must be aware of the extraordinary importance of this historic moment. We all have our eyes fixed on the White House, and, with respect to international matters, we follow anxiously all its moves.

As president of the American Society of International Law whose representative he was in the congress, Mr. Root attended the banquet, and in his capacity as toastmaster delivered the following address:

T CANNOT refrain, in opening the postprandial exercises I of this evening, from expressing the great satisfaction I feel in taking part in the transformation of the serious and sometimes dry exercises of our meetings into this social function. It is especially agreeable to me because $I$ cherish such rich and precious memories of hospitality received from our South American guests.

I have said many times to my own countrymen, without ever provoking resentment on their part, that I wish they could all learn a lesson in courtesy and the generosity of friendship from our brothers in South America. I should have felt that my own participation in this congress was imperfect and lacked an important element, if I could not have met you, my old friends of South America, in this gathering, which excludes the serious and the scientific, and seeks to cultivate and satisfy only the generous sentiments of friendship. 
It is with very great pleasure that $I$ announce to you all the completion of the first step in what I believe will be a very useful and important organization for united effort on the part of rcpresentatives of all the American nations in the direction of developing and strengthening the law of nations. You will recall that up to the time when the American Society of International Law was formed there had never been such a society in this wide world. The development of the law of nations was left to governments and to private individuals and to two great organizations which were international in their character, the Association of International Law and the Institut de Droit International, both of them founded in 1873.

But the first departure in the formation of a national society of international law, a society having a double aspect, one to promote the development of the law internationally and the other to educate and instruct the people of the particular nations in their knowledge of the law of nations, was that which was set in motion by our friend Dr. James Brown Scott, some ten years ago.

The response, which I confess was to me far beyond expectation, of the people of this country to the efforts of that organization has demonstrated the practicability of such an institution; and the rapid changes in events have demonstrated year by year more cogently the necessity of such an institution. For if democracies are to take charge of government in international affairs, as they are taking charge of government in national affairs, it is of primary, of vital importance, that the people of every democracy shall learn their duties, as well as their rights, in their relations with each other. That cannot be done by the meeting of a few savants to cultivate the mystery of international law. That can be done only by broadening out into societies within which shall be gathered the men of all callings, lovers of liberty and jus- 
tice, who desire to do their duty as members of self-governing democracies, not alone toward themselves and their fellows, but toward all other nations. That can only be done by the creation of a great number of competent leaders of opinion who shall direct the impulses and the action of their neighbors and their fellow-citizens in the performance of the duty of administering the affairs of nations by the rule of international justice.

The demonstrated success of this new departure of the Society of International Law has resulted in the formation of similar societies in Europe, and it has resulted, through much communication, correspondence, and intercourse, through the devoted efforts of Dr. Scott, through a personal visit paid by our friend, the former ambassador to France, Robert Bacon, in the formation of a national society of international law in every American republic. Every one has its society, prepared to perform the great duty of instructing the people of the country in their international duties and in aiding the government of their country in its international intercourse.

Yesterday there was inaugurated an institute - the American Institute of International Law - which gathered together the representatives of all these national societies, twenty-one in number, which representatives were elected by each of the national societies whose members may attend its meetings and are eligible for membership in the Institute. Through that Institute there will be hereafter an institution for the expression and effectuation of the good will and love for peace and sense of justice of all the American countries with relation to each other.

Peace we all love; good will we all entertain; friendship we all feel. The nature of man is kindly; all the peoples of the earth prefer to be friends. But good will, friendliness and good understanding, because they have no institutions 


\section{INTERNATIONAL LAW IN THE AMERICAS 299}

through which they may receive effect, stand powerless before sinister designs, schemes of aggrandizement, and the lust for power and wealth. Here in the Americas is created an institution through which the good will and friendliness of the American peoples may have voice and effectiveness....

We approach the conclusion of this festival. I shall ask you to join me in several appropriate toasts.

First, rise and drink to the President of the United States.

(The guests arose and drank a toast to the President of the United States.)

And now rise again, and drink to a toast to which I know every heart will respond in consonance with the intelligence of every guest at this board - the American Republics, one and indivisible, forever.

(The guests arose and drank a toast to the American Republics.)

And yet again, join in a toast of broader import, to humanity, the universal concert of civilized nations, for the progress of civilization and the reign of peace in the world - to humanity, which the religion we all profess aims to make perfect - to peace and good will.

(The guests arose and drank a toast to humanity.) 

INDEX 



\section{INDEX}

Abraham, Heights of, 12 .

Atlanta, capture of (1864), 116.

Adams, John Quincy, Amcrican presi- Austria, House of, 10, 287. dent, 137.

Adirondacks, the, 61 .

Alaska, 102.

Alaska Boundary dispute, the, 97, 154, $164,291$.

Alaska Boundary Treaty, the, 102.

Albany, New York, 19, 20.

Albany county, New York, $26,45,57$.

Algeria, 145.

Algonquin Indians, 4, 5, 12, 14.

American Academy in Rome, the, 195, $197,206,208 \mathrm{f}$.

American Federation of Arts, address before the, 205-209.

American ideals, address on the preservation of, 259-266.

American Institute of Architects, addresses before, 189-196, 198-204.

American Institute of International Law, the, 295.

American Revolution, the, 284.

American Society for the Judicial Settlement of International Disputes, the, 295.

American Society of International Law, the, $295,296,297$.

Amherst, Jeffrey, English general, 27, 31 . Amherst College, 42.

Antwerp, 206.

Armenians, destruction of the, 283.

Army War College, the, 197, $200 \mathrm{f}$., 203.

Art and architecture in America, address on, 189-196.

Arthur, Chester Alan, American president, address on, 109-113.

Asbury African church, the, in New York, 40, 77.

Association of International Law, the, 297.

Austrian Succession, War of the, 286.

Avery, Charles, professor of chemistry, $42 \mathrm{f}$.

Aztecs, the, 8.

Balbed, ancient city of Syria, 192.

Bacon, Francis, English philosopher, 11.

Bacon, Robert, American diplomat, 298.

Bacon, William J., trustee of Hamilton College, 41.

Baden-Powell, Sir Robert, British general, 134.

Balfour, Arthur James, British minister, 268.

Baltimore, 195, 211.

Banks of Newfoundland, the, 7 .

Barnard, Frederick Augustus Porter, American educator, 77.

Barnes, Albert, American Biblical commentator, 62 .

Barrett, George Carter, American jurist, memorial address on, $241 \mathrm{ff}$.

Bear, the, Iroquois clan, 6 .

Beardsley, Samuel, American jurist, 61.

Beaumarchais, Pierre Augustin Caron de, French financier and writer, 141.

Beecher, Henry Ward, American clergyman, 135.

Belgium, 285.

Benson, Egbert, 27.

Berlin, Congress of (1878), 283, 288.

Bill of Rights, the, 53 .

Boer War, the, 97.

Bogotá, 99.

Boston, 31, 191.

Botanic Garden, the, in New York, 40.

Bourbon restoration, the, in France, 284.

Bradley, Dan, 27.

Brazil, 9, 276. 
Bréboeuf, Jean de, French Jesuit mis- Carnegie Institution of Washington, the, sionary, 12, 27 .

Bristol, Eli, 27.

British Columbia, 102.

British Dominions, the, 285.

Bronson, Green Carrier, American lawyer, 61.

Brougham, John, American actor, 135.

Brown, Elmer Ellsworth, address at the inauguration of, $71 \mathrm{ff}$.

Brown, Samuel Gilman, president of Hamilton College, 42.

Brown University, address at, 91-101.

Buchanan, James, American president, 233.

Building of the Pan American Union, the, 202.

Bulfinch, Charles, American architect, 190, 191, 204.

Burgess, John William, professor in Columbia University, 75.

Burgoyne, John, English general, 20, 21.

Burr, Aaron, American vice-president, 48.

Business and politics, address on, 249258.

Butler, Nicholas Murray, president of Columbia University, $75 \mathrm{f}$.

Butler, Richard, manufacturer, 217.

Cabots, the, navigators, 7.

California, University of, 73.

Cambon, Jules Martin, French ambassador, parting address to, $145 \mathrm{ff}$.

Campbell, Douglas, American lawyer and historian, 86.

Canada, 3, 97, $291 \mathrm{f}$; French rule in, 4-15; addresses on, 151-187; the Canadian reciprocity agreement, 163187.

Cannon, Joseph Gurney, American congressman, address on, $213 \mathrm{ff}$.

Capitol, the, at Washington, 195.

Carnegie, Andrew, gift of, towards the John Hay Library, 91.

Carnegie Endowment for International Peace, the, 295.

72.

Carnot, Marie François Sadi, French president, address on the assassination of, $149 \mathrm{f}$.

Carolinas, the, 7, 20, 116.

Caroline, affair of the, 291.

Carter, James Coolidge, American lawyer, 237.

Cartier, Jacques, French navigator, 7 .

Cassatt, Alexander Johnston, American railroad president, 195.

Castilian Days, 92.

Catlin, Marcus, professor of mathematics at Hamilton College, 23.

Cayugas, Iroquois tribe, 5 .

Cecil, William, English statesman, 11.

Central America, 221, 222, 265, 271, 272.

Champlain, Lake, 20, 291; address at the tercentenary celebration of the discovery of, 3-15.

Champlain, Samuel de, French explorer, $3,8,12,15$; his discovery of Lake Champlain, $4 \mathrm{f}$.

Character, importance of, on the bench, 234, 239.

Characteristics, inherited and acquired, 24.

Charles V, emperor (1519-1556), king of Spain (as Charles I, 1516-1556), 9.

Charles I, king of England (1625-1646), 11.

Charleston, South Carolina, 191.

Charlotte county, New York, 57.

Chartism, 284.

Chastellux, Marquis de, French general and author, 143.

Chattanooga, battle of (1863), 116.

Chicago, 137, 199.

Chicago Exposition, the, 194, 206, 207.

Chili, bay of, 100.

China, 99-102, 262, 285.

City and country life compared, $62 \mathrm{f}$.

Civil War, the, 115 ff., 119 ff., 123-127, 219, 233, 261.

Clark, Clarence Don, American senator, 178. 


\section{INDEX}

Clark, Erastus, first treasurer of Hamilton College, 27, 41.

Clarkson, Matthew, American general, $26,45$.

Clayton-Bulwer Treaty, the (1850), 99, 102.

Cleveland, Grover, American president, 126, 237, 272 f.; address on, 105-108.

Clifford, Nathan, American jurist, 233.

Clinton, George, American statesman, $25,26,57,81$.

Clinton Light Horse, the, 35.

Colombia, 99.

Colonists, English, in America, motives of, $11 \mathrm{f}$.

Columbia College and University, 39, 40, 71 ; address at, 75-79.

Columbia School of Mines, the, 77 .

Columbus, Christopher, 158.

Commission for the Extension and Perfection of the Park System of Washington, the, 197, 200.

Commons, House of, in England, 284.

Commune, the, 284 .

Conkling, Roscoe, American senator, 61.

Connecticut, 14, 30, 32.

Conquistadores, 9, 158.

Constituent Assembly, the, in France, 284.

Constitution, the, 21, 53, 111, 125, 253.

Constitutions, establishment of, 285.

Continental Congress, the, 33.

Corinth, battle of (1862), 116.

Court of Honor, the, at the Chicago Exposition, 207.

Corpens, battle of the (1781), 144.

Crimean War, the, 283.

Cromwell, Oliver, 11.

Cuba, 220, 221, 265.

Cummins, Albert Baird, American senator, 187.

Curriculum, changes in the, $47 \mathrm{f}$.

Dakota, 252.

Danville, Illinois, 213, 214 .

Darling, Henry, president of Hamilton College, 42.
Dartmouth, Earl of, patron of Dartmouth College, 18, 21, 32; patron of the school at Lebanon, 28.

Dartmouth College, 27, 41, 42; address at, 17-22; relation to Hamilton College, 17; contemplated establishment of, on the Mohawk, $31 \mathrm{f}$.

Dartmouth College Case, the, 21 .

Davis, John, American jurist, memorial address on, $239 \mathrm{f}$.

Deane, James, missionary to the Oneidas, $18,19,20,27$.

Declaration of Independence, the, 123.

Delaware, river, 6, 10, 20.

Delaware, state, 7 .

Delta Phi, college fraternity, 47.

Democracy, weaknesses and dangers of, $50-59$, $288 \mathrm{f}$., $292 \mathrm{f}$.; inferior military efficiency of, 293; address on the effect of democracy on international law, 281-294.

Denio, Hiram, trustee of Hamilton College, 41, 61.

Denonville, Marquis, governor of Canada, 13.

Depew, Chauncey Mitchell, Amcrican orator, 85.

Dexter, Simon Newton, trustee of Hamiiton College, 41.

Dillingham, William Paul, American senator, $182 \mathrm{f}$.

Dixon, Joseph Moore, American senator, 179.

Dodge, William E., 217.

Dogger Bank incident, the, 268.

Drake, Francis, English navigator, 7, 11, 158.

Duane, James, American jurist, 81.

Duquesne, Fort, 13.

Duquesne, Marquis, governor of Canada, 12.

Dutch, the, 10, 85-90.

Dutch East India Company, the, 9.

Dutch founders of New York, address on the, 85-90.

Dwight, Sereno, president of Hamilton College, 40. 
Dwight, Theodore William, American jurist, 76.

Dwight, Timothy, American educator, 37.

Eastern Question, the, 137.

Edict of Nantes, revocation of the, 89 .

Edison, Thomas Alva, American inventor, 47.

Education, liberal, value of, $57 \mathrm{f}$.

Educational institutions, differentiation of, $72 \mathrm{f}$.

Egypt, 271.

Eliot, Charles William, American educator, 17.

Elizabeth, queen of England (15581603), 11, 154.

Engineers' School of Application, the, 197, 200.

England, 11, 27, 97, 98, 100, 146, 152, $153,160,271,283,284$.

Episcopacy, reaction against, in England, 11.

Europe, 8, 10, 123, 146, 154, 181, 194, 252, 271, 272, 283, 286, 287, 292, 296.

Evarts, William Maxwell, American lawyer and senator, 217 .

Fenian raid, the, 291.

Ferdinand VII, king of Spain, 285.

Field, Stephen Johnson, American jurist, 233.

Finley, John Huston, American educator, $81 \mathrm{f}$.

Fisher, Samuel Ware, president of Hamilton College, 34, 42.

Fisheries regulations, the, 292 .

Florida, 7, 8.

Foot, Moses, 27.

Fort Fisher, North Carolina, address to the veterans of, $119 \mathrm{ff}$.

Fort Schuyler, New York, 33.

Fort Stanwix, New York, 21, 28, 32, 61.

Fort Sumter, attack on, 117.

France, 89, 100, 207, 227, 286, 292; struggle of, for the empire of America,

4-15; presentation of the Franklin Grasse, Comte de, French admiral, 142. medal to, 141-144; parting address to M. Cambon, $145 \mathrm{ff}$; the assassination of President Carnot, 149 f.; element of nobility in the first French Republic, $264 \mathrm{f}$; progress of democracy in, 284. Franchise extension in England, 284.

Francis, refugee, 89.

Franklin, Benjamin, American statesman, 13,47, 63, 151; addresses on, 141-144.

Frederick II (the Great), king of Prussia, $35,286$.

French Academy in Rome, the, 195, 209.

French canal company, see Panama Canal Company.

French Revolution, the, 10.

Frobisher, Martin, English navigator, 7, $11,158$.

Frontenac, Comte de, governor of Canada, 12, 13, 14.

Fuller, Melville Weston, American jurist, memorial address on, $237 \mathrm{f}$.

Fuller, William H., 217.

Gama, Vasco da, Portuguese navigator, 158.

Garfield, James Abram, American president, 110, 111, 112, 150.

General Electric Company, the, 47.

Genesee, river, 5 .

George III, king of England, 18, 21, 28, 32.

Germany, 10, 98, 100, 227, 292.

Gibbon, James, cardinal, address on, $211 \mathrm{f}$.

Gilbert, Humphrey, English navigator, 7 .

Gold, Thomas R., 27.

Gosnold, Bartholomew, English navigator, 7.

Gourgues, Dominique de, Gascon soldier, 7 .

Governor's Island, government station at, 197.

Grant, Ulysses Simpson, American general and president, 116, 233.

Grant Memorial, the, 202. 
Great Britain, 95, 99, 107, 153, 164, 165, 166, 268, 276; contends with France for the sovereignty of North America, 4-15.

Grcat Lakes, the, 20, 153.

Greece, 192, 271 .

Greek-letter societies, 46 f.

Grey, Lord, governor-general of Canada, 159.

Grotius, Hugo, Dutch publicist, 281.

Guiteau, Charles, assassin, 110.

Gustavus Adolphus, king of Sweden (1611-1632), 10.

Hadfield, George, American architect, 190.

Hague, The, First Peace Conference at (1899), 98, 288; Second (1907), 288.

Hague Convention, the, for the Pacific Settlement of International Disputes, 98.

Hague Tribunal, the, 98, 99.

Half Moon, the, 8.

Hallet, Stephen, American architect, 190.

Hamilton, Alexander, American statesman, $19,33,48,81,82,296$; his connection with the founding of Hamilton College, 26, 27, 34, 36, 45.

Hamilton College, 65, 73, 75, 76, 77; address at the centenary of, 23-44; relations with Union College, $45 \mathrm{f}$.

Hamilton Oneida Academy, predecessor of Hamilton College, 23, $25 \mathrm{f}$., 33-40, 45.

Hampden, John, English statesman, 11.

Hanover, New Hampshire, 18.

Harlan, John Marshall, American jurist, memorial address on, 233 .

Harrison, Benjamiu, American president, 126.

Harvard, John, 72.

Harvard College, 41.

Hawaii, 102.

Hay, John, secretary of state, address on, 91-101.

Hayes, Rutherford Birchard, American president, 126.
Hay-Herran Treaty, the, 99.

Henry VIII, king of England, 11.

Henry IV, king of France (1589-1610), 10, 146, 154.

Herkimer, Nicholas, American general, 21, 61.

Herkimer county, New York, 26, 35, 45.

Hoban, James, American architect, 189, $190,195,204$.

Ho-de-no-saunee, 5 .

Holland, 9, 85, 89, 285.

Holy Alliance, the, 282, 285 .

Hong-Kong, 100.

Hood, Thomas, English poet, 95.

Hopkins, Sewal, 27.

Hornbostel, Henry, American architect, 203.

Howard, John Eager, American general, 144.

Hudson, river, 5, 6, 8, 20.

Hudson, Henry, English navigator, 8.

Huguenots, the, 11, 89; in Florida, 7 .

Hundred Years' War, the, 146.

Hunt, Richard Morris, American architect, 190.

Huntingdon, Countess of, English religious leader, 29.

Huron, Lake, 7.

Hutchinson, Ann, Antinomian enthusiast, 89 .

Illinois, University of, 73.

Indiana, 7.

Indies, the, 7.

Individualism, antagonists of, 49, $124 \mathrm{f}$.

Industrial life, various stages of, among the American Indians, 5.

Institut de Droit International, 297.

Interdependence, development of, 49.

International Commission, the, 292.

International law, science of, the product of the Thirty Years' War, 281; address on the spread of international law in the Americas, 295-299.

International Paper Company, the, 185.

Interstate Commerce Commission, the, 252, 256. 
Iroquois, the, Indian confederacy, 4-15, $20,30,31-34,61 \mathrm{f}$.

Irving, Washington, American historian and essayist, 88 .

Italy, 10, 98, 285.

\section{Jamaica, 157.}

James I, king of England, 11.

Jamcs II, king of England, 11.

Jamestown, Virginia, 8.

Japan, 100, 101, 207, 262, 276, 285.

Japanese, the, 278.

Jay, John, Amcrican statesman, 81.

Jefferson, Thomas, American president, $189,190,191 \mathrm{ff} ., 195,197,201,202$, 290.

Jews, the, 97.

Jolınson, Jacob, missionary, 32.

Johnson, Sir William, superintendent of Indian affairs in the American colonies, $28 \mathrm{f.}, 32$.

Johnston, Joseph Eccleston, Confederate general, 116.

Joint High Commission of 1898, the, 97 , 183.

Joliet, Louis, French-Canadian explorer, 12.

Jones, John Paul, naval officer, 144.

Joy, Charles Arad, American chemist, 77.

Jusserand, Jean J., French ambassador, reply of, $143 \mathrm{f}$.

Kansas-Nebraska conflict, the, 94 .

Kappa Alpha, college fraternity, 47.

Kent, James, American jurist, 25.

Kentucky, 7.

Kernan, Francis, American senator, 61.

Kiao-chau, China, 100.

Kirkland, Daniel, American clergyman, 27.

Kirkland, Captain George W., 35.

Kirkland, John Thornton, president of Harvard College, 41.

Kirkland, Gencral Joseph, mayor of Utica, 41, 61.

Kirkland, Samuel, American educator and missionary to the Indians, 17-22,
72; founder of Hamilton Oneida Academy, 23; his connection with Hamilton College, 24, 26, 27-38, 41, 44, 62.

Knox, Henry, American general, 33.

La Barre, Antoine Joseph Lefèvre de, governor of Canada, 13.

Labrador, 8.

La Caron, French missionary, 12, 27.

Lafayette, Marquis de, 142, 144.

Laird's, New York, 37.

Lansdowne, Lord, British minister, 268.

Lansing, John, 27.

La Salle, Sieur de, French explorer, 12.

Latin America, 285.

Latin race, the, 145.

Latrobe, Benjamin Henry, American architect, 189, 204.

Laurier, Sir Wilfrid, Canadian statesman, 163.

Lawrence, Frank Richard, 133.

Leavenworth School of Military Instruction, the, 117.

Lebanon, Connecticut, 30, 32; Wheelock's school at, 18, 27, 28.

Legge, William, see Dartmouth, Earl of.

L'Enfant, Peter Charles, Franco-Amcrican engineer and architect, 189, 190, $195,197,200,204$.

Lescarbot, Marc, French explorer, 7.

Liberty, meaning of, 136.

Likin, 101.

Lincoln, Abraham, American president, 94 f., 96, 102, 105, 150, 233.

Lincoln-Douglas debates, the, 94 .

Litchfield Observatory, the, 43.

Loire, the, 146, 283.

London, 18.

Iong House, the, see Iroquois.

Lord, Austin Willard, American architect, 203.

Lords, House of, in England, 281.

Lotos Club, address at the, 133-139.

Lottery, New York state, for the promotion of literature, $39 \mathrm{f}$., $48 \mathrm{f}$., $76 \mathrm{f}$.

Louis XI, king of France (1461-1483), 146. 


\section{INDEX}

Louis XIV, king of France (1643-1715). Milton, John, English poet, 11. $192,286$.

Louisburg, taken by the New England militia, 13.

McClure, David, Amcrican clergyman, 29.

McCumber, Porter J., American senator, 171, 174 f., 187.

McKim, Charles Follen, American architect, 189, 190, $206 \mathrm{f}$; memorial addresses on, 197-204.

McKinley, William, American president, $91,94,126,217,219$ f., 222 f., 250,251 , 256, 268.

Madison, James, American president, 190, 191.

Madrid, 95, 147.

Magna Charta, 11.

Maison Carrée, the, 192.

Manchu, domination of the, in China, 285.

Manchuria, 100, 101.

Marconi, Guglielmo, electrical engineer, 47.

Maria Theresa, empress of Austria, 287.

Marquette, Jacques, French Jesuit missionary, 12,27 .

Marshall, John, American jurist, 21, 190, 233, 290.

Martine, James Edgar, American senator, $176 \mathrm{f}$.

Maryland, 7, 211, 292.

Massachusetts, 7, 14, 85, 170, 171, 178.

Massachusetts Bay, 88.

Mediterranean Sea, the, 101, 102.

Menendez de Avilés, Pedro, Spanish soldier, 7 .

Metropolitan Museum of Art, the, 197, 206.

Mexican War, the, 46.

Mexico, 7, 52, 98.

Mexico, Gulf of, 8, 13.

Michigan, 7.

Michigan, University of, 73.

Millet, Francis Davis, American artist, 187; memorial address on, 205-209.

Mirabeau, Comte de, French orator, 144.

Missionary Ridge, battle of (1863), 116.

Mississippi, river, 12, 13, 20, 62, $286 \mathrm{f}$.

Mississippi, valley of the, $7,178,287$.

Missouri, 285, 353.

Mohawk, river, $18,20,32,34,61,64,65$, 86.

Mohawks, Iroquois tribe, 5, 6, 8 .

Monmouth, battle of (1778), 35 .

Monroe, James, American president, 137, 287.

Monroe Doctrine, the, 97, 107, 287; address on, 267-273.

Montana, 278.

Montcalm, Marquis de, French general, $12,14$.

Monticello, Virginia, 191, 201.

Montreal, 7, 27.

Monts, Pierre du Guast, Comte de, French explorer, 7.

Moody, Lady Deborah, 89.

Moore, Benjamin, American clergyman, 25.

Morgan, John Pierpont, American financier, 195; memorial address on, 227232.

Morris, Lewis, American patriot, 25.

Mullet, architect, 195.

Myers, Michael, 27.

Napoleon, 10, 284.

Napoleonic Wars, the, 282.

Negro, question of the, $125 \mathrm{ff}$.

Nelson, Knute, American senator, 164, 184.

Nevada, 278.

New Amsterdam, old name for New York city, 9, 87, 88, 90.

New England, 7, 30, 32, 62, 88, 161, 206; religious life in, 19; missionary spirit in, 27.

New England Society of New York, the, 85: address before, 267-273.

Newfoundland, 165.

New Hampshire, 14, 21.

New Hartford, New York, 40. 
New Jersey, 7, 14, 178.

Newport, Rhode Island, 191.

New York, city, 62, 191, 222, 223, 231, 275; address at the two hundred and fiftieth anniversary of the founding of its municipal government, $129 \mathrm{ff}$.; address on, at the Lotos Club, 133-139.

New York, state, 7, 14, 35, 53 f., 62, 65, 150,167 f., 170, 171, 178, 213, 237.

New York, University of the State of, 19 , $25 \mathrm{f} ., 45,81 \mathrm{ff}$.

New York Central Railroad, the, 137.

New York Peace Society, address before, 275-280.

New York Tribune, the, 96.

Niagara, river, 5.

Nicaragua, 99.

Nicholson, Joseph, Quaker writer, 89.

Nicolls, Sir Richard, first English governor of New York, 86, 88.

North, Edward, professor of Greek, 42.

North Carolina, 119.

Northeastern Boundary dispute, the, 291.

North River Sugar Refining Company Case, the, 242.

Norwich, Connecticut, 27 .

Nott, Eliphalet, president of Union College, 46, 48.

Occom, Samson, Indian student and preacher, $17 \mathrm{f} ., 19,20$.

Ohio, river, 6.

Ohio, state, 7.

Olney, Richard, American secretary of state, 272.

Onandago, Indian chieftain, 19.

Oneida county, New York, 25, 119; address before the Sons of Oneida, 6064.

Oneida Lake," $20,61$.

Oneidas, Iroquois tribe, $5,35,61,65$; labors of Kirkland among, 18-22, 28, $30,32,33$.

Onondagas, Iroquois tribe, 5 .

Ontario, province, 7, 152.

Ontario, Lake, $20,61$.
' Open door,' the, in China, 91, $100 \mathrm{f}$. Oregon Boundary dispute, the, 291.

Oregon treaty, the (1846), 102.

Orient, the, 9, 102.

Oriskany, battle of (1777), 21, 35, 61 .

Oriskany Creek, 34, 61, 64.

Ottawa, address at, 157-161.

Ottoman Empire, the, 281, 283.

Pacific Ocean, the, 101 f.

Pacific railroads, the, 117.

Palatinate, the, 94.

Palmyra, 192.

Panama, republic, 99, $278 \mathrm{f}$.

Panama, Isthmus of, 102, 221, 265.

Panama Canal, the, 99, 101, 201, 265. :

Panama Canal Company, the, 99.

Pan American Scientific Congress, Second, 295.

Paris, France, 95, 143 f., 191.

Paris, New York, 25.

Parish, Elijah, American clergyman, 29.

Peekskill, New York, 137.

Peking, China, 137, 262.

Penney, Joseph, president of Hamilton College, 42.

Pennsylvania, 7, 14, 170, 178.

Penobscot Bay, 8.

Pepperell, William, American general, 13.

Peter I (the Great), czar of Russia (16821725), 10.

Peters, Christian Henry Frederick, astronomer, 43.

Philadelphia, 33, 34, 143, 151, 249, 250.

Philip II, king of Spain (1556-1598), 9.

Philippines, the, 102, 123, 137, 206, 220, 221.

Phoenicians, the, 102.

Pickering, Timothy, American statesman, 33 f., 36.

Pietro, C. I., sculptor, 23.

Pike County Ballads, 92.

Pilgrims, the, 7.

Pious Fund, the, 98.

Plantagenets, the, 146.

Platt, Jonas, 27. 
Plattsburg, address at, 3-15.

Political Science Association, the 295.

Polk, James Knox, American president, 270.

Pomeroy, John Norton, Amcrican educator, 73.

Ponce de Leon, Juan, Spanish explorer, 7.

Pontgravé, François, French explorer, $7,8$.

Port Arthur, fortress, 100.

Porto Rico, 220.

Port Royal, 7.

Portugal, 9, 279, 285.

Positivist philosophy, the, $78 \mathrm{f}$.

Poutrincourt, Sieur de, French explorer, 7.

Pragmatic Sanction, the, of Charles VI, 287.

Princeton, New Jersey, 105.

Princeton College, 29, 42.

Principles, importance of, 58.

Prussia, 10.

Pujo investigation, the, 230.

Pure Food Law, the, 253, 256.

Puritans, the, in England, 11; in New

, England, 267.

Qucbec, city, 4, 7, 8, 12, 14, 27.

Queen Anne style in architecture, the, 193.

Quesada, Ernesto, remarks of, $295 \mathrm{f}$.

Raleigh, North Carolina, 116.

Raleigh, Sir Walter, English courtier and colonizer, 11.

Randolph, Edmund, American statesman, 190.

Reed, James A., American senator, 175.

Reform Bill of 1832, the, 284 .

Regent's Sword, peninsula of the, 100.

Reign of Terror, the, 284 .

Republican party, the, 257.

Revolution, the, 32 .

Rhode Island, 14.

Ribaut, Jean, French navigator, 7.

Richelieu, river, 4.

Richelieu, Cardinal de, French statesman, 10 ,
Richmond, Virginia, 191.

Richmond, Charles Alexander, president of Union College, 49.

Rio Grande, the, 4.

Roberts, Lord, British general, 292.

Roberval, Sieur de, viceroy of Canada, 7.

Robinson, Edward, American Biblical scholar, 62.

Rochambeau, Comte de, French general, 142.

Rodgers, John, American clergyman, 25.

Rogers, Publius V., trustee of Hamilton College, 41.

Roman Catholic Church, the, 98.

Roman supremacy, repudiated in England, 11.

Rome, 192, 195, 208, 209, 262.

Roosevelt, Theodore, American president, 85, 91, 94, 126, 129; tribute to, 217-226.

Root, Oren, professor of mathematics, Hamilton College, 23, 42.

Root, Oren, Jr., professor of mathematics, 23, 42.

Royal Grants, the, 61.

Rumania, 97, 207.

Russia, 10, 97, 100, 101, 207, 262, 263, 268, 285.

Saint Augustine, Florida, 7.

St. Clair, Arthur, American general, 33.

Saint Croix, river, 7.

Saint Gaudens, Augustus, sculptor, 141, 143.

Saint Gaudens, Louis, sculptor, 141, 143.

Saint Lawrence, river, 4, 6, 12, 13, 20.

St. Leger, Barry, British officer, 20, 21.

St. Louis, Missouri, 133.

Samoa, 97.

San Francisco, 144.

Sanger, Jedediah, 27.

Santo Domingo, 97.

Saratoga, surrender of Burgoyne at, 21 .

Savannah, 116.

Saxons, the, 283.

Scandinavia, 285.

Schenectady, New York, $26,45,46,47,86$. 
Schuyler, Philip, American general, 25 f., 33.

Scotland, 30, 31, 94.

Scott, James Brown, American publicist, 297, 298.

Second Empire, the, in France, 284.

Self-poise, a characteristic of the Dutch, 89.

Senecas, Iroquois tribe, $5,6,29,30$.

Sergeant, John, 27.

Seward, Thomas W., trustee of Hamilton College, 41.

Seward, William Henry, American statesman, 101.

Seymour, Horatio, governor of New York, 41.

Shakspere, William, 11, 95.

Shantung, Chinese province, 100.

Shaw Monument, the, in Boston, 191.

Sherman, James Schoolcraft, American vice-president, memorial address on, 65-69.

Sherman, Richard U., 65.

Sherman, Willett, 65.

Sherman, William Tecumseh, American general, address on, 115-118.

Shiloh, battle of (1862), 116.

Shipman, Andrew J., 81.

Siberia, 102.

Sigma Phi, college fraternity, $46 \mathrm{f}$.

Silesia, $\mathbf{2 8 6 .}$

Silver Purchase Act, the, 107.

Slavery, overthrow of, 123-127.

Smith, William Alden, American senator, 183.

Society in Scotland for Propagating Christian Knowledge, the, 28, 30.

Soto, Fernando de, Spanish explorer, 7.

South America, 221, 222, 265, 271, 272, $279,296 \mathrm{f}$.

South Carolina, 14.

Spain, 96, 220, 268, 279, 285, 286; decline of, $8 \mathrm{f} ., 147$.

Spanish Succession, War of the, 286.

Speer, Emory, Amcrican jurist, 260.

Spencer, Joshua A., American lawyer and trustee, 41,61 .
Spenser, Edmund, English poet, 11.

Stadacona, Indian village, 4.

States General, the, in France, 284.

Steuben, Baron Frederick William von,

Prussian-American general, 35, 36, 37.

Storrs, Henry Randolph, American congressman, 61.

Story, Joseph, American jurist, 233.

Strong, William L., mayor of New York, $85,87$.

Stryker, Melancthon Woolsey, president of Hamilton College, 41, 42 .

Stuyvesant, Peter, Dutch governor of New York, 86, 90.

Suffren de Saint-Tropez, Pierre André de, French admiral, 144.

Sullivan, John, American general, 33.

Supreme Court, the, $289 \mathrm{f}$.

Susquehanna, river, $5,6,20,31$.

Sweden, 10.

Swedes, the, 87.

Swettenham, Sir Alexander, governor of Jamaica, 157.

Switzerland, 285.

Tadousac, 7.

Tennessee, 7.

Teutonic race, the, 145 .

Third Republic, the, in France, 284.

Thirty Years' War, the, 10, 281 .

Thornton, William, American architect, $190,195,204$.

Throckmorton, refugee, 89 .

Ticonderoga, 4, 8.

Tien-tsin, China, 262.

Tilden, Samuel Jones, American statesman, 269.

Tocqueville, Alexis de, French statesman and writer, quoted, $55,890 \mathrm{f}$.

Tonquin, 100.

Torrey, John, Amcrican botanist, 77.

Traey, Marquis de, viceroy of Canada, 13.

Trade Commission, the, 253, 254, 256.

Tryon county, New York, 57.

Turgot, Baron de, French minister, 144.

Turkey, 97, 271.

Turks, the, 283. 
Turtle, the, Iroquois clan, 6.

Tuttle, Timothy, 27.

Tutuila, 97.

Union College, founding of, $26,45 \mathrm{f}$; aided by a state lottery, 39 f., 48 f., 77; address at, 45-59.

Union League Club of Chicago, the, address before, 259-266.

Union League Club of New York, the, 109 ; addresses before, 123-127, 217226.

Union League Club of Philadelphia, the, address before, 249-258.

Upson, Anson Judd, professor of rhetoric, 43.

Utiea, New York, $37,40,41,61,65,66$, 67, 119.

Utiea Trust and Deposit Company, the, 66.

Utrecht, Treaty of (1713), 154, 286.

Valley Forge, 35.

Van Amringe, John Howard, dean of Columbia College, 76.

Van Brunt, Charles H., American jurist, address on, $245 \mathrm{ff}$.

Van Cortlandt, Pierre, lieutenant-governor of New York, 25.

Vanderbilt, Frederick William, American capitalist, 135.

Van Rensselaer, Stephen, 'the Patroon,' 19.

Venetians, the, 102.

Venezuela, 97, 98.

Venezuela boundary controversy, the, 107, 269, 272.

Vergennes, Comte de, French minister, $1 \notin 1$.

Vermont, 112.

Verplanck, Gulian, regent of the University of the State of New York, 26, 45.

Verrazano, Giovanni da, Italian navigator, 7.

Vicksburg, capture of (1863), 116.

Vienna, 95, 283.

Vienna, Congress of (1815), 288.
Villa Mirafiori, the, in Rome, 195.

Virginia, 7, 8, 14, 191, 192, 292.

Virginia, University of, 191.

Wales, Salem Howe, journalist, 217.

Walters, Henry, American capitalist, 195.

Wampum, demonetization of, $87 \mathrm{f}$.

Washington, city, 123, 222; architectural problems of, 189-204.

Washington, George, American president, 13, 20, 21, 33, 34, 35, 36, 102, 105, 144, 190, 195, 197, 200, 201, 202, 264 .

Webster, Daniel, American statesman, 21, 296.

Wei-hai-wei, 100.

Wells, Samuel, 27.

West India Company, the, 89.

West Indies, the, 137.

Westphalia, Congress of (1648), 288.

Westphalia, Peace of (1648), 281, 286.

West Virginia, 7.

Wetmore, Edmund A., trustee of Hamilton College, 41.

Wheelock, Eleazar, Ameriean educator, $18,19,21,22,24,27,28,29,30,31,32$, 72.

Whitaker, Nathaniel, 18.

White City, the, 194, 199, 207.

White House, the, 189, 190, 195, 197, 201 f., 203.

Whitesboro, New York, 40.

Whitestown, New York, 26, 35, 37, 45, 61.

Williams, John Sharp, American senator, 180, 183 f., 185.

Winthrop, Theodore, American novelist, 71.

Wisconsin, University of, 73.

Wolf, the, Iroquois clan, 6.

Wolfe, James, English general, 14, 27.

Wood Creek, 20, 61.

Yale, Elihu, 72.

Yangtze, the, 100.

Yates, Abram, Jr., 26, 45.

Yates, Joseph, 26, 45.

Yorktown, surrender of (1781), 35. 
PRINTED AT

THE HARVARD UNIVERSITY PRESS

CAMBRIDGE, MaSS., U.s.A. 



This book is DUE on the last date stamped below

OEC 181946 NOV $12 V_{2}^{1} 1955^{1954}$ DEC 81956 MAY2 2.1957

ConRL FEB 201969 FEB

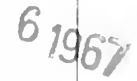

(D) NaV 12 nTs 


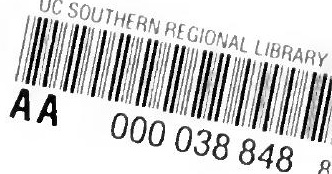


